UNIVERSIDADE DE SÃO PAULO

ESCOLA DE ARTE, CIÊNCIAS E HUMANIDADES

PROGRAMA DE PÓS-GRADUAÇÃO EM MUDANÇAS SOCIAIS E

PARTICIPAÇÃO POLÍTICA

GIOVANA CIOFFI NASCIMENTO

O uso público sustentável em áreas protegidas: uma análise do Turismo de Base Comunitária do Território Tradicional Caiçara de

Picinguaba

São Paulo 


\section{O uso público sustentável em áreas protegidas: uma análise do Turismo de Base Comunitária do Território Tradicional Caiçara de Picinguaba}

Dissertação apresentada à Escola de Artes, Ciências e Humanidade da Universidade de São Paulo para obtenção do título de Mestre em Ciências pelo Programa de Pós-Graduação em Mudança Social e Participação Política.

Versão corrigida contendo as alterações solicitadas pela comissão julgadora em 1 de março de 2021. A versão original encontra-se em acervo reservado na Biblioteca da EACH/USP e na Biblioteca Digital de Teses e Dissertações da USP (BDTD), de acordo com a Resolução CoPGr 6018, de 13 de outubro de 2011.

Área de Concentração: Dimensão Socioambiental, Patrimônio e Políticas Territoriais

Orientador: Sidnei Raimundo Coorientador: Davis Gruber Sansolo

São Paulo 
Autorizo a reprodução e divulgação total ou parcial deste trabalho, por qualquer meio convencional ou eletrônico, para fins de estudo e pesquisa, desde que citada a fonte.

CATALOGAÇÃO-NA-PUBLICAÇÃO

(Universidade de São Paulo. Escola de Artes, Ciências e Humanidades. Biblioteca) CRB 8 - 4936

Nascimento, Giovana Cioffi

O uso público sustentável em áreas protegidas: uma análise do turismo de base comunitária do território tradicional caiçara de Picinguaba / Giovana Cioffi Nascimento ; orientador, Sidnei Raimundo ; coorientador, Davis Gruber Sansolo. - 2021

$195 \mathrm{p}$ : il.

Dissertação (Mestrado em Ciências) - Programa de PósGraduação em Mudança Social e Participação Política, Escola de Artes, Ciências e Humanidades, Universidade de São Paulo Versão corrigida

1. Turismo - Aspectos socioambientais - Picinguaba (SP). 2. Comunidades locais. 3. Área de proteção ambiental. 4.

Desenvolvimento sustentável. I. Raimundo, Sidnei, orient. II. Sansolo, Davis Gruber, coorient. III. Título.

CDD 22.ed. - 910.98161 
Nome: NASCIMENTO, Giovana Cioffi

Título: O uso público sustentável em áreas protegidas: uma análise do Turismo de Base Comunitária do Território Tradicional Caiçara de Picinguaba

Dissertação apresentada à Escola de Artes, Ciências e Humanidade da Universidade de São Paulo para obtenção do título de Mestre em Ciências pelo Programa de Pós-Graduação em Mudança Social e Participação Política.

Área de Concentração: Dimensão Socioambiental, Patrimônio e Políticas Territoriais

Aprovada em: 01/03/2021

\section{Banca Examinadora}

Prof. Dra. Camila Gonçalves de Oliveira Rodrigues Universidade Federal Rural do Rio de Janeiro

Prof. Dr. Marcos Bernardino Universidade de São Paulo Dr. Felipe Augusto Zanusso de Souza Universidade Estadual de Campinas 
Às mulheres Cioffi: Ana, Odila e Isabela.

Por serem a força motriz da minha caminhada. 


\section{AGRADECIMENTOS}

À minha mãe, pelo amor e apoio incondicional. Pela força que me transmitiu ao criar duas filhas em meio a tantos desafios dos quais só uma mulher é capaz de entender.

À minha tia Odila Cioffi, por ser a minha maior referência, incentivadora e companheira nessa longa e intensa estrada que é a vida acadêmica.

À minha irmã, pelas largas conversas que me acalantaram em momentos de incertezas e hesitações.

Ao meu tio João Cioffi, pela presença constante e indubitável.

Ao meu amor Everton Batista, pelo companheirismo, compreensão e pelos mapas que avivam este e outros tantos trabalhos.

À Raissa de Campos, querida amiga, que me permitiu fazer de sua casa um abrigo onde encontrei paz para seguir.

À Lívia Quintero, irmã que a vida me deu, que mesmo longe se faz tão presente em afeto.

Ao Sidnei Raimundo, que orientou meus passos por esses dois anos com calma, cuidado e respeito.

Ao Davis Sansolo, por estar perto desde sempre, me encorajando e guiando aos melhores caminhos profissionais.

Ao Santiago Bernardes, Anna Maria de Andrade e Fernanda Filipini por me abrigarem nos períodos de campo com tanto carinho.

Por último, à comunidade tradicional caiçara de Picinguaba, que me acolheu e reviveu histórias e sentimentos para que esse estudo fosse possível. Que nunca percam de vista a potência que emanaram para lutar pelos seus direitos e pelo seu território.

Foram anos turbulentos, houve uma pandemia, mas aqui estou. 


\section{RESUMO}

NASCIMENTO, Giovana Cioffi. O uso público sustentável em áreas protegidas: uma análise do Turismo de Base Comunitária do Território Tradicional Caiçara de Picinguaba. 2021. 195 p. Dissertação (Mestrado em Ciências) - Escola de Artes, Ciências e Humanidades, Universidade de São Paulo, São Paulo, 2021. Versão corrigida.

A história do território tradicional caiçara de Picinguaba se assemelha a de muitos outros que ameaçados por diferentes interesses econômicos e pressionados por políticas de proteção ambiental. A criação de duas áreas protegidas (APs), o Parque Estadual da Serra do Mar (PESM) e a Área de Proteção Ambiental Marinha do Litoral Norte (APAMLN), ao mesmo tempo que contribui para frear a exploração econômica e ocupação humana ( sobretudo o PESM, instituído no período na Rodovia Rio-Santos) no território, representou a supressão e criminalização de diversas práticas tradicionais que compõem o modo de vida da comunidade caiçara ali presente. Mesmo a presença de áreas protegidas no local representar certas limitações, nos últimos anos foi desenvolvido um turismo de massa no local, principalmente direcionado à visitação da Ilha das Couves, ilha inserida ao território tradicional em questão, devida sua relevância à história da comunidade. Entre os atores do oferecimento turístico, destaca-se a própria comunidade, que por diferentes motivos assumiu o turismo como principal meio de subsistência, e as agências de turismo náutico da região central de Ubatuba. Para superar o cenário de intensa degradação ambiental e sociocultural que ali se estabeleceu, houve a articulação entre atores de diferentes âmbitos de atuação no território para promover o uso sustentável da Ilha das Couves pautado nos princípios do turismo de base comunitária (TBC). A partir disso, este trabalho teve como objetivo compreender como se deu o processo de ordenamento e gestão do turismo, bem como seus elementos e impactos, de modo a contribuir para a mitigação dos conflitos socioambientais em APs. Por meio da observação participante, da aplicação de entrevistas com lideranças formais e informais e da análise documental, foi possível verificar como a promoção da gestão participativa por meio de parcerias que envolvam concretamente as comunidades é capaz de potencializar a efetividade das APs, promover o bem-estar dos habitantes locais e estimular que haja um engajamento público direcionado ao alcance do planejamento e manejo comunitário dos territórios.

Palavras-chave: Conflitos socioambientais. Áreas protegidas. Comunidade tradicional caiçara. Turismo comunitário. Uso sustentável. 


\begin{abstract}
NASCIMENTO, Giovana Cioffi. Sustainable public use in protected areas: an analysis of Community Based Tourism in the Traditional Caiçara de Picinguaba Territory. 2021. 195 p. Dissertation (Master in Science) - School of Arts, Sciences and Humanities, University of São Paulo, São Paulo, 2021. Corrected version.

The history of caiçara traditional territory of Picinguaba is similar to many others that have been invaded by economic activities and pressured by environmental protection policies. The creation of two protected areas (PAS), the Serra do Mar State Park and the Marine Coastal Environmental Protection Area, while contributing to curb economic exploitation and human occupation in the territory, represented the suppression of several traditional practices that make up the way of life of the Caiçara community present there. Despite the resistance of the protected areas, in recent years, mass tourism has been developed in the area, mainly aimed at visiting Ilha das Couves, an island inserted in the traditional territory in question, due to its relevance to its history the community. Among the tourist's actors, the community itself stands out, which was forced to assume tourism as its primary means of subsistence, and the nautical tourism agencies in the central region of Ubatuba. To overcome the scenario of intense environmental and socio-cultural degradation that was established, there was an articulation between actors from different areas of activity in the territory to promote the sustainable use of Ilha das Couves based on community-based principles tourism (TBC). This work aimed to understand how the tourism planning and management process took place, as well as its elements and impacts, to contribute to the mitigation of socio-environmental conflicts in PAs. Through participant observation, the application of interviews with formal and informal leaders, and documentary analysis, it was possible to verify how the promotion of participatory management through partnerships that concretely involve communities can enhance the effectiveness of PAs, promote the well-being of local inhabitants, and to stimulate that there is a public engagement directed to reach the planning and community management of the territories.
\end{abstract}

Keywords: Socio-environmental conflicts. Protected areas. Caiçara traditional community. Community tourism. Sustainable use. 


\section{LISTA DE ABREVIATURAS}

ABPP

ABPTP

AMBP

AP

APAMLN

ATNU

CCT

FCT

FF

GT

LDA

MPF

OTSS

PESM

PNPCT

POGC

SPU

TAUS

TBC

UC
Associação de Barqueiros e Pescadores de Picinguaba

Associação de Barqueiros e Pescadores Tradicionais de Picinguaba

Associação de Moradores do Bairro de Picinguaba

Área protegida

Área de Proteção Ambiental Marinha do Litoral Norte

Associação de Turismo Náutico de Ubatuba

Capacidade de carga turística

Fórum de Comunidades Tradicionais de Angra, Paraty e Ubatuba

Fundação Florestal

Grupo de trabalho

Instituto Linha d'Água

Ministério Público Federal

Observatório de Territórios Sustentáveis e Saudáveis da Bocaina

Parque Estadual da Serra do Mar

Política Nacional de Desenvolvimento Sustentável dos Povos e Comunidades Tradicionais

Plano de ordenamento e gestão comunitária para o uso público sustentável da Ilha das Couves do território tradicional caiçara da Picinguaba

Secretaria do Patrimônio da União

Termo de Autorização de Uso Sustentável

Turismo de base comunitária

Unidade de Conservação 


\section{Sumário}

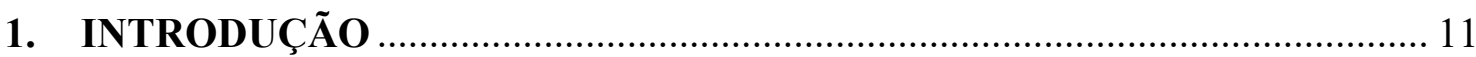

1.1. LITORAL NORTE DE SÃO PAULO: REVISÃO HISTÓRICA E CONTEXTUALIZAÇÃO.

1.2. O PARQUE ESTADUAL DA SERRA DO MAR E O NÚCLEO

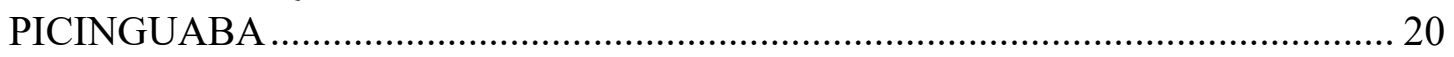

1.3. ÁREA DE PROTEÇÃO AMBIENTAL MARINHA DO LITORAL NORTE 25

1.4. HISTÓRIA E CARACTERIZAÇÃO DE PICINGUABA E ILHA DAS COUVES

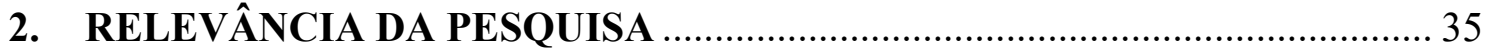

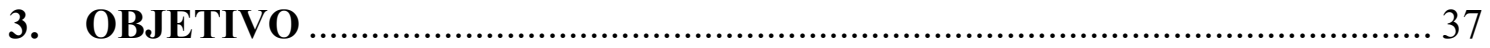

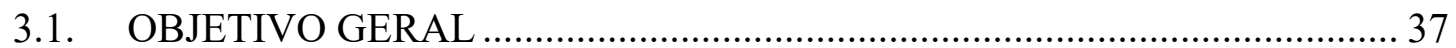

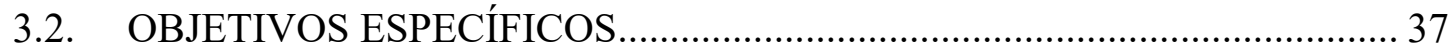

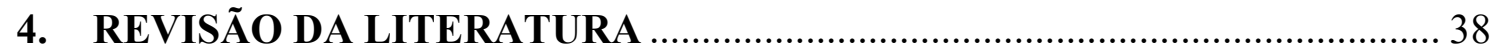

4.1. GOVERNANÇA AMBIENTAL ............................................................ 40

4.2. TURISMO DE BASE COMUNITÁRIA....................................................... 49

4.2.1. TERRITÓRIO E CONCEITOS ADJACENTES ......................................53

4.2.2. A RELAÇÃO ENTRE NATUREZA E COMUNIDADES

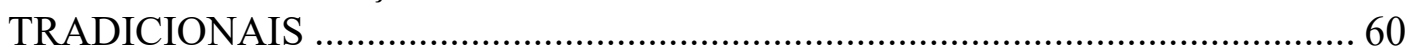

4.2.3. ÁREAS NATURAIS PROTEGIDAS E A QUESTÃO TERRITORIAL 67

4.2.4. O COMUM E A GESTÃO COMUNITÁRIA …………………………..... 73

5. PROCEDIMENTOS TÉCNICOS DE PESQUISA............................................. 77

5.1. INSERÇÃO NO TERRITÓRIO TRADICIONAL CAIÇARA DE

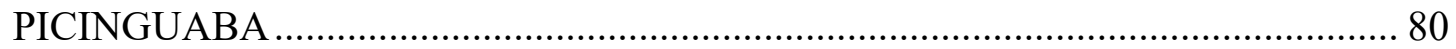

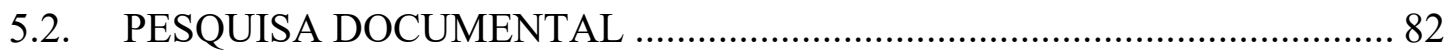

5.3. ENTREVISTA COM LIDERANÇAS FORMAIS E INFORMAIS ................ 83

5.4. SISTEMATIZAÇÃO E ANÁLISE DE DADOS ............................................ 86

6. ORDENAMENTO E GESTÃO COMUNITÁRIA DO TURISMO NO TERRITÓRIO TRADICIONAL CAIÇARA DE PICINGUABA ………………..... 87

6.1. O AVANÇO TURÍSTICO E OS CONFLITOS TERRITORIAIS: UM RECORTE TEMPORAL ENTRE 2016 E 2018 ………………………………....... 87

6.2. CENÁRIOS PROPOSTOS PARA O ORDENAMENTO TURÍSTICO....... 106

6.2.1. Termo de Autorização de Uso Sustentável (TAUS) ................................ 106

6.2.2. Cessão à Prefeitura Municipal de Ubatuba.............................................. 110

6.2.3. Cessão à pessoas físicas ou jurídicas ......................................................... 113 
6.3. ORDENAMENTO TERRITORIAL: ATORES, AÇÕES E INSTRUMENTOS PARA O DESENVOLVIMENTO DO TBC PICINGUABA

6.4. O TERRITÓRIO PÓS ORDENAMENTO: REPERCUSSÕES E IMPACTOS SOCIAIS, AMBIENTAIS E ECONÔMICOS 148

7. O ORDENAMENTO E GESTÃO COMUNITÁRIA DE PICINGUABA: REFLEXÕES À LUZ DA FUNDAMENTAÇÃO TEÓRICA ................................ 154

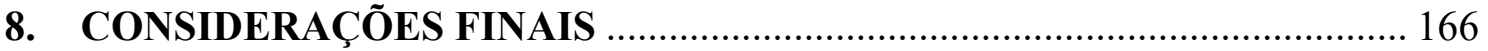

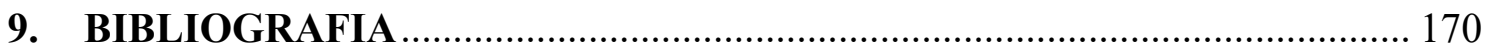

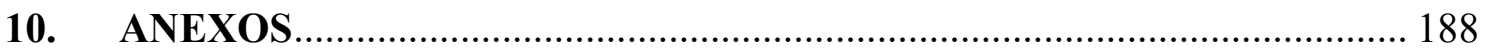

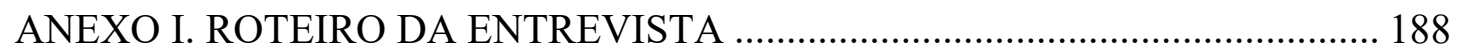

ANEXO II. TERMO DE CONSENTIMENTO LIVRE E ESCLARECIDO............ 192

ANEXO III. CAPA DO PLANO DE ORDENAMENTO E GESTÃO

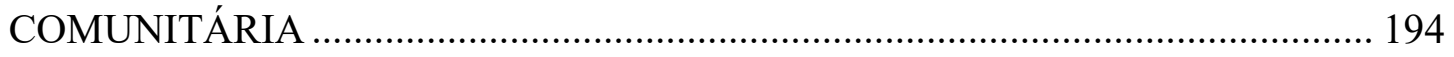

ANEXO IV. MAPA DO PROJETO DE ORDENAMENTO MARINHO DA ILHA DAS COUVES DO GT TBC PICINGUABA ……................................................ 195 


\section{INTRODUÇÃO}

\subsection{LITORAL NORTE DE SÃO PAULO: REVISÃO HISTÓRICA E CONTEXTUALIZAÇÃO}

Com 161 km de extensão, o litoral norte de São Paulo abrange as cidades de São Sebastião, Ilhabela, Caraguatatuba e Ubatuba, somando juntas 164 praias e 17 ilhas. A região se destaca por uma expressividade provocada pela combinação de dimensões ambientais, culturais e socioeconômicas intensas e complexas. Ao mesmo tempo que abrange a grandiosidade de uma das maiores parcelas de Mata Atlântica do Brasil e é território de comunidades indígenas, quilombolas e caiçaras, a área vivencia os efeitos da forte exploração turística, portuária, petrolífera e da pesca.

Os aspectos geográficos e geológicos da região tiveram influência direta na sua história socioeconômica. O litoral norte paulista, em sua porção continental, desenvolveuse cercado pelas montanhas que compõem a Serra do Mar e pelo mar. Devido ao avanço em determinados trechos da escarpa ${ }^{1}$ da Serra em direção a planície costeira, houve a formação de pequenas praias o que, segundo Raimundo (2007, p. 89),

[...] transforma a paisagem natural desse setor num chamariz para as práticas de turismo e veraneio, pois aliam em áreas muito próximas, a praia e a serra bem florestada.

De acordo com Marandola Jr et al. (2013), o perfil geológico, climático e florístico conferem vulnerabilidade à região, fator potencializado com a ocupação desordenada que recortou partes da Serra e retirou grandes parcelas de vegetação. Quando o alto índice de radiação solar, característico de regiões intertropicais, é combinado com a influência oceânica e com a elevação brusca do relevo, há o favorecimento da ocorrência constante de chuvas, intensificando o fluxo de umidade da área.

Em razão do perfil geológico do litoral norte, a ocupação humana se deu em diversos trechos de forma vertical, no sentido das encostas, originando uma tensão no

\footnotetext{
${ }^{1}$ Escarpa pode ser entendida como uma porção onde há a elevação súbita do solo, dando origem a um penhasco ou a uma encosta íngreme (SÃO PAULO, 2019).
} 
território devido ao perigo de desastres de origem hidrometeorológica, como deslizamentos ou inundações. Esse cenário torna-se ainda mais crítico, considerando que a época de maior índice pluviométrico coincide com o período de maior volume turístico, ocorrido entre dezembro e março, causando maior pressão sobre o meio ambiente e aumentando o número de pessoas expostas a riscos ambientais (MARANDOLA JR et al., 2013; SÃO PAULO, 2012).

O processo de urbanização dessa região nas últimas décadas vinculou-se a novos vetores de transformações socioeconômicas e espaciais dos municípios, resultando em formas distintas de ocupações territoriais e na configuração de novos problemas. Entretanto, antes de avançar nessa discussão, retornemos alguns séculos. O processo de povoamento do litoral paulista teve início anteriormente ao período colonial, com a presença de comunidades indígenas, principalmente de designação linguística tupiguarani. Dentre os povos que constituíam essa família linguística, os Tupinambás eram grupos tupis que ocupavam - ao menos no momento da chegada portuguesa - do litoral norte paulista até a foz do rio Amazonas (LUCHIARI, 1996; SCATAMACCHIA e MOSCOSO, 1987). Segundo relatos, os tupinambás

[...] tinham uma localização ecológica relacionada a um habitat de clima úmido, sem estação seca pronunciada. Estavam ligados à distribuição das áreas florestadas, que atendia suas necessidades constantes de terras virgens em virtude do tipo de cultivo utilizado. A busca do local para a instalação da aldeia, além de uma visão estratégica visava também o abastecimento de água e possibilidade da complementação da subsistência através da pesca e caça (SCATAMACCHIA e MOSCOSO, 1987, p. 51).

Os Tupinambás tinham a roça como principal tradição produtiva, fator que moldava seu padrão de distribuição na paisagem. Como esta prática agrícola exige um tempo maior para a recuperação do solo, as ocupações das áreas eram efêmeras, considerando a necessidade de se encontrar terras férteis para produção. Contudo, Uchôa (2009) aponta que alguns grupos assumiram a pesca como uma das principais formas de subsistência, o que poderia ser explicado pela alta disponibilidade de recursos marinhos 
em comparação aos terrestres, pelo menos inserido a condição do bioma Mata Atlântica. O autor ainda destaca essa influência na origem da cidade de Ubatuba.

Ubatuba surgiu do aldeamento Tupinambá de Iperoig (Ypiruyg = rio das perobas), região rica de boa madeira para embarcações, das quais eram os Tupinambás hábeis canoeiros e construíam grandes canoas de capacidade para até 60 pessoas (UCHOA, 2009, p. 8).

Esses grupos possuem papel central na origem do tipo étnico e cultural do litoral norte de São Paulo, o caiçara ${ }^{2}$. Fruto da miscigenação do indígena com o branco e, de maneira menos expressiva, também com o negro, os caiçaras absorveram a prática da roça como principal contribuição indígena a sua cultura material. Contudo, Cândido (1987) indica que o caiçara, mais que pelo seu traço étnico, é definido por seus modos de vida ligados às condições naturais do litoral paulista. A gênese do caiçara remete ao período colonial, quando o litoral foi utilizado para cultivos agrícolas. Após constituída, a cultura caiçara sobreviveu a todos os ciclos econômicos desenvolvidos no litoral norte paulista (LUCHIARI, 1996).

De acordo com Calvente (1999), a ocupação europeia na região se inicia em meados dos séculos XVI e XVII, com a concessão das sesmarias e a formação de engenhos de açúcar e cultivos de fumo, aniz, entre outros. Essa fase, apesar de curta, influenciou traços arquitetônicos que permaneceram até os dias atuais e tornou o canal de São Sebastião rota para embarcações portuguesas que faziam comércio na área. A partir do século XVIII, o litoral tornou-se rota de ligação entre áreas de mineração e o exterior, época em que se instituiu a alternância entre a economia de subsistência e a economia de exportação (LUCHIARI, 1996).

No início do século XIX o litoral foi introduzido ao ciclo cafeeiro ${ }^{3}$ e chegou a ter uma produção maior do que a da região de Lorena, maior área produtora do Vale do Paraíba.

\footnotetext{
2 "Homem do litoral", em tupi-guarani (SANTOS, 2013).

${ }^{3}$ De acordo com Luchiari (1996), muitas das áreas desflorestadas da região são resultados do período da cafeicultura. França (1954 apud RAIMUNDO, 2007) assinala que a produção de café foi realizada no sistema de plantation e se estendeu pela costa e por Ilhabela até a cota de $300 \mathrm{~m}$, substituindo inúmeras florestas pré-existentes.
} 
Esse período foi marcado pela economia baseada no trabalho escravo, mesmo após a proibição de tráfico negreiro ${ }^{4}$. Segundo Pessoa (2020), a costa norte paulista foi cenário para a chegada e redistribuição clandestina de africanos que eram levados para lavouras localizadas serra acima. $\mathrm{O}$ autor ainda aponta que a análise da cultura material ou o acesso à memória de comunidades quilombolas evidenciam indícios da presença de cativeiros ilegais nas praias.

Ao revés, o litoral norte da antiga província de São Paulo por anos figurou como espaço menor na análise da escravidão no oitocentos, em contraponto a sua explosão demográfica e concentração em municípios cafeeiros como Rio Claro, Bananal e Campinas. Análises seminais, reiteradas em pesquisas posteriores, entenderam àquele espaço como áreas de domínio dos caiçaras, com forte vínculo com o setor de abastecimento, resultando em uma demografia típica de áreas empobrecidas, com acesso limitado à propriedade escrava, marcada pelo protagonismo de pescadores e camponeses (PESSOA, 2020, p. 2).

A partir da segunda metade do século XIX, o cultivo do café entra em decadência e posteriormente há a abolição da escravatura. Dessa forma, há um esvaziamento da região e comunidades que não se moveram para o planalto ou para centros urbanos no litoral, como Santos, foram obrigadas a fortalecer suas atividades de subsistência, resultando na ampliação do vínculo com aquele território. Os centros comerciais que haviam se formado no litoral norte se estagnaram e tornaram-se pequenas vilas (RAIMUNDO, 2007). Conforme Colistete (2015), entre 1872 e 1920 a participação dessa região na população total do estado sofreu um brusco declínio, decaindo de 30\% para $10 \%$.

\footnotetext{
${ }^{4}$ Duas datas marcam a institucionalização da proibição da tráfico de escravos. Na primeira, 7 de novembro de 1831, foi promulgada uma lei específica proibindo o tráfico e declarando a liberdade de todos os negros trazidos ilegalmente a partir daquela data. Os anos seguintes a esta promulgação vivenciaram total desrespeito à legislação, não só pelos proprietários de escravos, como também pelo Estado. Na segunda data, 4 de setembro de 1850, instituiu-se uma nova lei para a proibição, agora com a pressão mais incisiva do governo britânico (COTA, 2011).
} 
Raimundo (2007) assinala que essa época de isolamento parcial dessas comunidades representou a construção da identidade caiçara vinculada à um modo de vida no qual a agricultura e pesca eram práticas centrais. Era um período de "tempos lentos", as técnicas eram limitadas garantindo a pouca transformação do território e havia tempo e espaço para que a floresta voltasse a crescer. Fortalecia-se também crenças e simbolismos diretamente ligados à apreensão da natureza.

Utilizando as ricas matas existentes, inicia-se [...] a construção das canoas de voga, que lembram embarcações indígenas, feitas em um único tronco, e que passam a ser comercializadas com outros locais (CALVENTE, 1999, p. 31).

Essas canoas, que são propulsionadas por remos, eram utilizadas para acessar pequenos centros comerciais da região (como por exemplo, Maresias e Boiçucanga que possuíam certa integração com Santos), onde as comunidades vendiam seus pescados e compravam outros alimentos que não produziam e roupas (RAIMUNDO, 2007).

As comunidades caiçaras desse território se desenvolveram até certo período sob tradição lavradora-pescadora, na qual há a pesca artesanal ou em pequena escala e a agricultura familiar. A pesca ${ }^{5}$ era uma prática realizada exclusivamente por homens, com exceção da pesca da tainha que, por ser feita através da técnica de arrasto de praia, dependia de uma ação coletiva (ADAMS, 2000). O início do século XX foi um importante período para o avanço de técnicas pesqueiras caiçaras. A chegada da imigração japonesa representou a chegada de inovações, como as redes de cerco flutuante e barcos a motor.

Em nossa visão, as populações caiçaras eram constituídas, no passado, primordialmente por lavradores-pescadores, com raras exceções em comunidades dependentes essencialmente da pesca.

\footnotetext{
${ }^{5}$ Alguns dos principais métodos de pesca caiçara são: "rede de espera", no qual as redes são posicionadas com boias na parte superior e pesos na parte inferior para que permaneçam armadas verticalmente; tarrafa, rede em formato cônico com pesos distribuídos por toda sua circinferência e uma corda no centro, utilizada para puxá-la e diminuir seu diâmetro; o picaré, pequena rede manejada por pelo menos dois pescadores utilizada para realizar o arrasto de praia (RAMIRES e BARRELLA, 2003); emalhe, tipo de pesca passiva, na qual uma rede retangular é posicionada para que ocorra a retenção de peixes na malha; espinhel, consiste em várias linhas secundárias com anzóis e iscas presas a uma principal, também funciona de forma passiva; e cerco, grande rede utilizada para cercar cardumes de peixe com o uso de embarcações.
} 
Após a introdução do cerco e do barco a motor, em meados do século XX, essas comunidades passaram a dedicar uma parte cada vez maior de seu tempo às atividades da pesca, em detrimento da lavoura (ADAMS, 2000, p. 154).

É importante ressaltar que apesar do povoado caiçara possuir propriedades e relações entendidas como particulares, elas não eram formalizadas por instituições ou organizações. Havia uma lógica de cooperação baseada nas trocas ou empréstimos de produtos e nos mutirões direcionados a ajudar ou prestar certos serviços, como por exemplo a construção de casas $^{6}$. As formas de lazer das comunidades envolviam festas, procissões, jogos, danças e histórias baseadas em folclores caiçaras ${ }^{7}$. Os trabalhos coletivos também eram importantes formas de construção de laços sociais (ADAMS, 2000).

Os anos de 1930 foram cenário para o início de um turismo tímido no litoral norte de São Paulo, com a chegada dos primeiros turistas e especuladores de terra através de uma estrada imperial que ligava o território ao Vale do Paraíba (BARBOSA et al., 2010). Calvente (1999) pontua que a produção e disseminação da ideia de praias como atrativos turísticos se inicia cerca de dois séculos atrás. Nesse movimento, a praia e, consequentemente, essa região deixa de ser vista como local de trabalho, sem valor, para tornar-se um destino amplamente procurado.

Segundo Ângelo (1992), as décadas que seguiram presenciaram a evolução da pesca industrial na região quando, em 1960, Ubatuba se tornou um expressivo centro produtor de pescado. Esse tipo de pesca, principalmente voltada a captura de sardinha, exigia equipamentos maiores e mais $\operatorname{caros}^{8}$, normalmente aquem do alcance financeiro do caiçara local. O avanço da pesca industrial não só impactou a economia de subsistência das comunidades, como também contribuiu para a desarticulação da cultura caiçara,

\footnotetext{
${ }^{6}$ Tradicionalmente, as casas caiçaras eram feitas de pau-a-pique, telhados de sapê e chão de terra batida (ADAMS, 2000).

${ }^{7}$ Diegues (1983) aponta que a proliferação de igrejas protestantes impactou os folclores caiçras e valores religioso, provocando a origem de conflitos entre caiçaras.

${ }^{8}$ Utilizavam-se principalmente traineiras, embarcações de pesca com redes especiais para capturar sardinha (DIEGUES, 1973).
} 
considerando que embarcações de fora recrutavam jovens locais para trabalhar nas temporadas de pesca.

Coexistente às outras atividades praticadas, nos anos de 1970, a região vivencia uma forte ofensiva do turismo, marcada e possibilitada pela construção da rodovia Rio-Santos (BR-101). O plano de fundo do planejamento e concretização dessa estrada remete fortemente à dois momentos da segunda metade do século XX: primeiro, o pós-segunda guerra mundial, época conhecida como a "era do desenvolvimento" e que fortaleceu o desejo dos países (principalmente os subdesenvolvidos) de alcançar o "progresso" (ESTEVA, 1996); segundo, a ditadura militar, na qual a BR-101 representou o avanço do projeto nacional-desenvolvimentista característico do período militar (FONTANELLI, 2018).

Cada novo palmo de estrada consegue medir um novo índice de desenvolvimento potencial. O litoral Rio-Santos, porque região de vocação turística inata, atingirá as etapas todas de seu pleno desenvolvimento incorporando os objetivos que o querem região turística de prioridade primeira (EMBRATUR, 1975 apud FONTANELLI, 2018).

Raimundo (2007) assinala que a instalação de rodovias representou também umas das últimas estratégias do Estado para promover a ocupação das áreas "fronteiriças" da zona costeira com as populações semi-isoladas. As implementações seguiram algumas premissas, como a alcance de instalações portuárias ou de belezas cênicas. No litoral norte de São Paulo, o terminal petrolífero de São Sebastião e as pequenas praias entrecortadas pela Serra do Mar são exemplos importantes de locais que moldaram a criação de estradas na região.

A chegada da Rio-Santos e da exploração turística resultou na intensificação de tensões sociais ocasionadas pela especulação imobiliária, turismo em massa, privatizações de espaços públicos, atribuindo à região uma supervalorização da terra. Esse processo estimulou a degradação ambiental, com cortes nas montanhas, aterramento

\footnotetext{
${ }^{9}$ EMBRATUR. Turis: Desenvolvimento turístico do litoral Rio-Santos. Embratur, 1975.
} 
de praias e soterramento de florestas. Houve também um complexo conflito entre Estado, investidores e famílias caiçaras, as quais se viram obrigadas a vender suas terras por valores irrisórios e adaptar seus modos de vida (BARBOSA et al., 2010; FONTANELLI, 2018).

As posses que continuaram nas mãos das famílias caiçaras foram diminuindo e aumentando de valor, os que ficaram sem terra passaram por um processo de proletarização e, como mão de obra barata, piorando as condições materiais de existência, ao mesmo tempo que aumentava a informação e o apelo com relação aos bens de consumo.

As comunidades caiçaras passaram a ficar concentradas em determinados locais. Mesmo nestes, na maior parte dos casos, a faixa à beira-mar foi vendida e cada vez mais os pescadores, morando nas encostas, sofreram dificuldades para transportar o equipamento de pesca até à beira-mar, pois as residências de veraneio são construídas muradas, diferentemente das residências tradicionais (CALVENTE, 1999, p. 34).

Este cenário se intensificou com o aumento da expansão turística nos anos de 1980, período em que o Estado implementou medidas como a ampliação da rede de energia elétrica e de um sistema de estradas, balsas e pontes. $\mathrm{O}$ efeito dessas medidas pode ser observado na análise do crescimento populacional da região. Entre 1970 e 1980 a população urbana duplicou, sendo o aumento mais expressivo em Caraguatatuba e Ilhabela; e até os anos 2000, houve um acréscimo populacional de quase 180.000 habitantes (MANDAROLA JR et al., 2013).

O padrão de urbanização do litoral norte, de acordo com Mandarola Jr et al. (2013), se estabeleceu sem abranger de forma conjunta políticas urbanas e planejamento territorial das cidades. A rápida expansão populacional não foi acompanhada por mudanças estruturais que atendessem às novas realidades locais. $\mathrm{O}$ autor aponta que em 2003 a rede coletora de esgoto compreendia apenas $25 \%$ dos domicílios urbanos em Caraguatatuba, 3\% em Ilhabela, 29\% em São Sebastião e 17\% em Ubatuba. 
A urbanização dessa região deve muito ao desenvolvimento turístico, mas não só à ele. Segundo Fontanelli (2018), a abertura da BR-101 foi determinante para a modernização regional que já vinha acontecendo com a implementação de empreendimentos como a Usina de Angra dos Reis (RJ), o porto e o Terminal Marítimo da Petrobrás em São Sebastião, e o terminal portuário da Ilha Guaíba (RJ), destinado ao escoamento de minério de ferro extraído em minas do sudeste.

Em meio ao intenso processo de ocupação, modernização e uma destruição ambiental sem precedentes, há a emersão de grupos ambientalistas que pressionaram para que medidas restritivas fossem adotadas. Assim, em 1977, foram criados o Parque Estadual da Serra do Mar (PESM), Parque Estadual de Ilhabela e Parque Estadual da Ilha Anchieta. Nas décadas seguintes outras áreas protegidas estaduais de diferentes modalidades foram instituídas, como a Área de Proteção Ambiental Marinha do Litoral Norte (APAMLN).

A fim de disciplinar e racionalizar a utilização dos recursos naturais da zona costeira, em 2004 foi instituído o zoneamento ecológico-econômico (ZEE) no litoral norte a partir do Plano Estadual de Gerenciamento Costeiro, aprovado em 1998. O ZEE é um importante instrumento para compatibilizar o desenvolvimento socioeconômico e proteção ambiental, com base na identificação de unidades territoriais que devam ser objeto de regulamentos específicos e no uso de quatro instrumentos: sistema de informações, planos de ação e gestão, controle e monitoramento (BARBOSA et al., 2010; SÃO PAULO, 1998).

Conforme Itani (2018), o ZEE não foi efetivo em barrar a expansão da mancha urbana para áreas mais restritas, que ocorreu principalmente pelo crescimento dos assentamentos irregulares e pela construção de loteamentos e condomínios. A autora destaca que esse avanço também direcionou-se aos limites das áreas protegidas e que essas situações de desconformidade foram regularizadas por meio da revisão do zoneamento em 2017 , validando usos e ocupações territoriais que haviam sido proibidos em sua primeira versão.

Com o turismo e a ocupação de veraneio sendo consolidados nas últimas décadas como orientadores da economia regional, a sazonalidade torna-se um aspecto importante para a população local, pois dependem do "aquecimento" da economia em períodos de temporada. A partir de estimativas da CBH-LN, foi dimensionado que nesses períodos a 
população flutuante pode chegar a 1 milhão de pessoas, ocasionando intensa redução de disponibilidade hídrica e colapso dos sistemas de esgoto (SÃO PAULO, 2012).

Esse problema é agravado pelo fato das águas marinhas e estuarinas adjacentes à costa constituírem áreas de berçário, reprodução, crescimento e alimentação de muitas espécies, inclusive aquelas exploradas pela pesca (SÃO PAULO, 2012, p. 30).

Esse contexto territorial, ao ser observado sob a realidade das comunidades caiçaras, torna-se ainda mais grave. Além da expulsão de seus territórios e coibição de seus modos de vida tradicionais, nos últimos anos os caiçaras vêm sofrendo com a omissão estatal por frequentemente habitarem áreas mais isoladas, irregulares ou de risco, o que faz com que sejam menos atendidos pela rede pública, tendo que adotar por diversas vezes soluções alternativas de saneamento, como fossas rudimentares (SÃO PAULO, 2012).

A partir da revisão e contextualização territorial do litoral norte paulista, as próximas seções possuem a finalidade de aprofundar alguns recortes importantes nesse processo histórico. Destaca-se a essencialidade para este trabalho de realizar uma revisão histórica do Parque Estadual da Serra do Mar, da Área de Proteção Ambiental Marinha do Litoral Norte e do Território Tradicional Caiçara de Picinguaba, sem perder de vista a correlação entre eles.

\subsection{O PARQUE ESTADUAL DA SERRA DO MAR E O NÚCLEO PICINGUABA}

Com o título de maior parque estadual de São Paulo, o Parque Estadual da Serra do Mar foi criado em 1977 e sua área tem uma extensão de aproximadamente 315 mil hectares sobrepondo 23 municípios, desde Itariri, no Vale do Ribeira, até a divisa com o estado do Rio de Janeiro, em Ubatuba (Figura 2). Devido ao seu tamanho, a unidade é dividida em dez núcleos com gestões específicas, todas sob responsabilidade da Fundação 
Florestal (Figura 1): Bertioga, Caraguatatuba, Cunha, Curucutu, Itariru, Itutinga Pilões, Padre Dória, Picinguaba, Santa Virgínia e São Sebastião (SÃO PAULO, 2008).

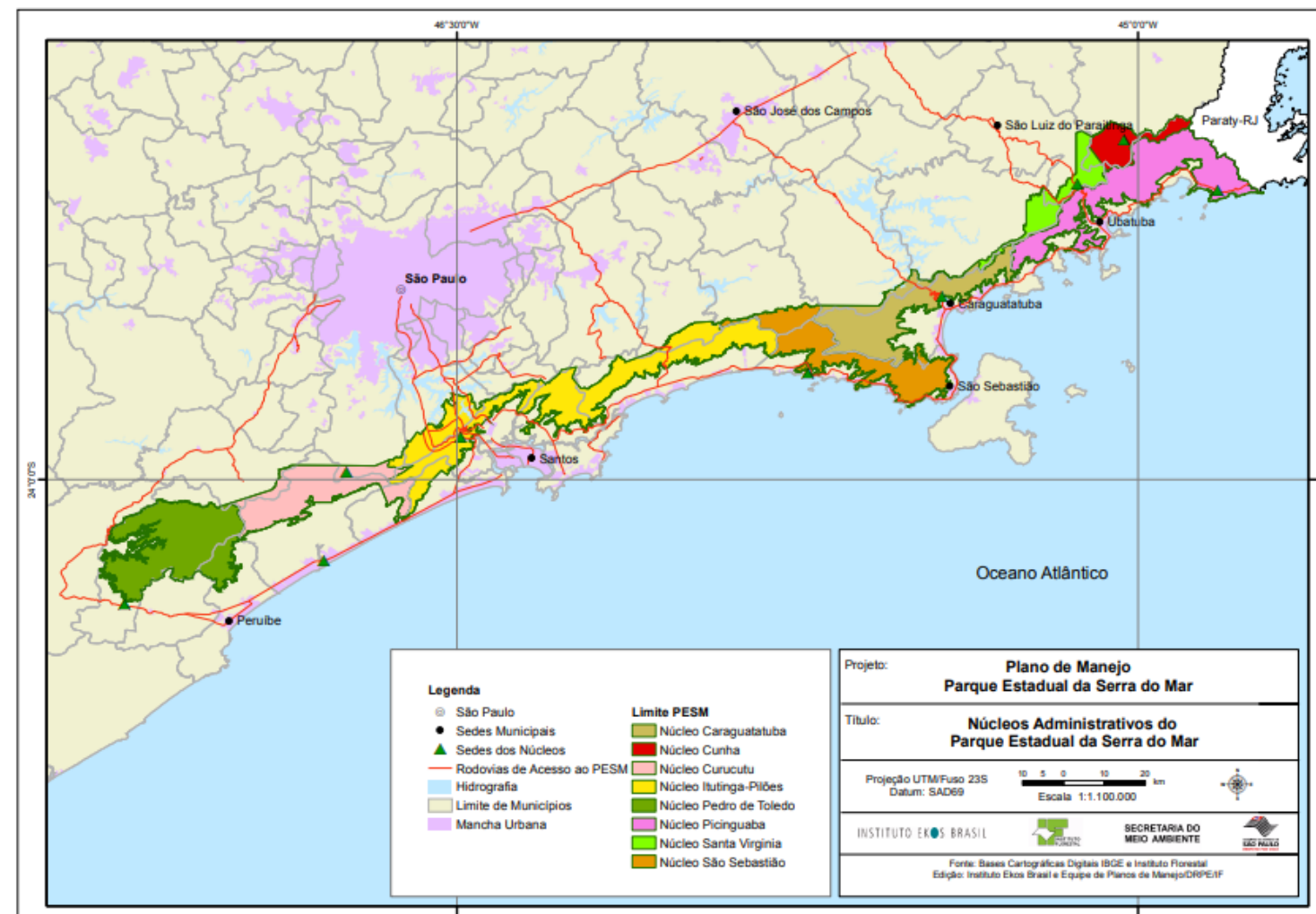

Figura 1. Núcleos administrativos do Parque Estadual da Serra do Mar. Mapa elaborado anteriormente a criação de dois núcleos: Bertioga e Padre Dória. Fonte: São Paulo, 2006.

A unidade abrange fragmentos remanescentes da Mata Atlântica, sendo uma das maiores porções contínuas preservadas do bioma no Brasil. Entre mais de 1.300 espécies de fauna e de 2.000 espécies de flora registradas, encontram-se muitas espécies ameaçadas de extinção, incluindo o macaco-prego-amarelo (Sapajus libidinosus), anta (Tapirus terrestris), palmito juçara (Euterpe edulis) e outras. Sua contribuição à conservação também envolve a proteção de nascentes e cabeceiras de rios, como o Tietê e o Paraíba do Sul (SÃO PAULO, 2008; BARBOSA et al., 2010).

A presença do PESM no litoral norte assegura que os serviços ecossistêmicos proporcionados pelo bioma à região sejam garantidos. Mesmo com sua degradação histórica e contínua, a Mata Atlântica exerce papel determinante na amenização do clima, na estabilização das encostas e escarpas da serra, e ainda proporciona ao local uma enorme beleza cênica. Atua também na proteção da fertilidade dos solos e na regulação 
dos fluxos dos mananciais, possibilitando o constante abastecimento hídrico para diversas comunidades (SÃO PAULO, 2008).

Para além da proteção aos aspectos ecológicos, o Parque abriga por toda sua extensão uma grande diversidade cultural, o que o coloca em incessante diálogo com outras territorialidades e patrimônios histórico-culturais. Fora as comunidades caiçaras, a unidade abrange terras indígenas Guarani e Quilombos. A relação entre o PESM e comunidades tradicionais, apesar de hostil, coloca questões necessárias. Ao mesmo tempo em que foi determinante para frear a ocupação turística dos territórios tradicionais e florestas, a criação do Parque representou a proibição repentina das culturas de subsistência e extrativismo (SÃO PAULO, 2008).

A proibição do uso direto da terra compõe uma das principais diretrizes sobre as quais a noção de Parque se fundamenta. Alinhado à categoria de proteção integral ${ }^{10}$ estabelecida pelo Sistema Nacional de Unidades de Conservação (SNUC), parques possuem

[...] como objetivo básico a preservação de ecossistemas naturais de grande relevância ecológica e beleza cênica, possibilitando a realização de pesquisas científicas e o desenvolvimento de atividades de educação e interpretação ambiental, de recreação em contato com a natureza e de turismo ecológico (SNUC, 2000, Art. 11).

É importante destacar que parques prevêem entre suas diretrizes o estímulo ao uso público, fazendo com que o lazer e turismo seja uma das principais atividades incentivadas e desenvolvidas em seus limites. Entretanto, esse uso nada tem haver com o turismo de massa que se desenvolveu em todos os atrativos do litoral norte. De acordo com o IBAMA, o turismo em parques deve propiciar a aproximação dos visitantes com a natureza, permitindo que estes interiorizem o significado das áreas protegidas, sua

10 "O objetivo básico das Unidades de Proteção Integral é preservar a natureza, sendo admitido apenas o uso indireto dos seus recursos naturais, com exceção dos casos previstos nesta Lei." (SNUC, 2000, não paginado). 
importância em termos de preservação, manejo e aproveitamento indireto dos recursos naturais e culturais (RAIMUNDO, PACHECO \& COSTA, 2011; BRASIL, 1999).

A criação do PESM é marcada por uma época na qual as políticas de conservação ambiental reproduziram um padrão antidemocrático, considerando o modus operandi dos governos militares da época. Esse padrão arbitrário de tomada de decisões negou a possibilidade de que a conservação florestal fosse um direito destinado às coletividades que habitavam e manejavam a área. O resultado foi o aumento dos conflitos sociais que o Estado não deu conta de resolver por conta da incongruência entre a conservação proposta e sua aplicabilidade no território (SIMÕES, 2010).

Dentre os 10 núcleos do PESM, Picinguaba destaca-se como um dos mais conflituosos em relação à presença de políticas ambientais mais restritivas. Instituído em 1979 e abrangendo uma área de 47.500 hectares do município de Ubatuba, é o único trecho do PESM que atinge o nível do mar, estendendo sua proteção aos ecossistemas costeiros e, por conseguinte, às comunidades tradicionais residentes. A parte norte do núcleo, composto pelos bairros de Camburi, Vila de Picinguaba, Sertão da Fazenda e Sertão de Ubatumirim, é onde reside a maior parte da população (SIMÕES, 2010).

De acordo com Simões (2010), essa área foi incluída ao PESM pelas seguintes razões: i) a construção da BR-101 atravessou o território por 17 quilômetros, abrindo caminho para uma elevada ocupação, mesmo possuindo uma planície litorânea muito estreita; ii) o avanço imobiliário passa a pressionar comunidades de menores renda para as encostas da Serra; iii) a compra ou apropriação de terras por pessoas de fora, além de agravar o desmatamento, pressiona o ecossistema local por não possuir infraestrutura adequada; iv) aquela região havia a elevada presença de residentes tradicionais.

Considerada a segunda porção do parque mais exposta às pressões do turismo e ocupação humana, Picinguaba ainda há questões não resolvidas relativas às necessidades de habitação da população local e o compromisso com a preservação. Segundo Vianna e Brito (1992), nos primeiros 12 anos de estabelecimento e consolidação do núcleo, metade das casas caiçaras foram vendidas à turistas. Naquele momento, há o início do delineamento do uso e ocupação da Vila de Picinguaba que reverbera até os dias atuais, no qual sua função central deixa de ser a pesca e agricultura para assumir um papel urbano, com casas de veraneio, pousadas e restaurantes. 
Mesmo com o surgimento do Núcleo Picinguaba, por pelo dois anos a área não sofreu ações estatais efetivas. Em 1983, a partir de um levantamento fundiário foi realizado um acordo verbal com os moradores, para que quem desejasse continuar na área respeitasse a propriedade do Estado, sendo proibido a venda ou novos desmatamentos. É importante pontuar que esses acordos traziam mais fragilidade às famílias caiçaras, considerando que culturalmente suas terras eram entendidas como comunais, fazendo com que não tivessem garantias legais de suas posses (RAIMUNDO, 2007).

Raimundo (2007), a partir das análises de transformações socioespaciais do território, observa que apenas em 2001 o Parque se tornou um obstáculo efetivo para o processo de difusão espacial de redes geográficas. Nos anos seguintes, segundo Sansolo (2009), a unidade adentrou a uma nova fase de planejamento para a regularização e zoneamento com a elaboração do seu plano de manejo, cuja versão final foi publicada em 2006.

A grande heterogeneidade de territórios nos quais a unidade se constitui fez com que o processo de zoneamento do plano de manejo identificasse três zonas de maiores conflitos: a) Zona de Ocupação Temporária (ZOT), ocupada por terceiros, que seguem diretrizes básicas de uso temporário viabilizando a coexistência entre ocupantes e o parque; b) Zona de Uso Conflitantes/Infra Estrutura de Base, onde passam rodovias, ferrovias, dutos e outras estruturas; e c) Zona Histórico-Cultural Antropológica (ZHCAn), que abrange comunidades caiçaras e quilombolas que vivem majoritariamente na região do Núcleo Picinguaba (SÃO PAULO, 2008; BARBOSA et al., 2010).

O processo de zoneamento contribuiu para que as políticas fossem melhor definidas e direcionadas. O ZHCAn tornou a compreensão cultural do território mais robusta, apontando para uma maior atribuição de direitos aos grupos tradicionais. Contudo, Simões (2010) aponta que o zoneamento não abrangeu todos os residentes tradicionais, apenas aqueles reconhecidos juridicamente. Ao mesmo tempo observa-se que mesmo na ZHCAn há a presença de edificações ocupadas por famílias não tradicionais. Ambas situações deram origem a longos processos de negociação que ainda ecoam.

Outro importante instrumento de gestão para o Núcleo Picinguaba, o conselho consultivo, foi formalizado apenas em 2005, 26 anos depois da instituição do núcleo. Esse fato demonstra mais uma vez o caráter antidemocrático do processo de instituição do 
Parque, refletindo décadas (1970-1980) em que a possibilidade de criação de instrumentos direcionados a co-gestão ainda era incabível. Segundo Sansolo et al. (2015), em sua composição há a presença de representantes das comunidades, o que trouxe ganhos à população local, como a retomada legítima de atividades que haviam sido proibidas e criminalizadas. Contudo, Queiroz (2015) realiza o seguinte apontamento:

Entretanto, qualquer interesse dessas populações que ultrapasse o que é reconhecido como legítimo de uma população tradicional, e que é permitido no território delimitado pelo Plano de Manejo, continua sofrendo forte regulação [...] (QUEIROZ, 2015, P. 90).

A análise do percurso histórico da Fundação Florestal - cujo início se deu a partir de um interesse do Instituto Florestal em agilizar o alcance de seus objetivos conservacionistas - de acordo com Souza (2020), demonstra a presença de constantes conflitos na gestão de diferentes categorias de APs oriundos de questões que envolviam, entre outros pontos, o déficit de comunicação com a população, a fragilidade na ocupação dos cargos em relação ao perfil profissional muitas vezes distoante da proposta e à falta de recursos humanos, a nebulosidade de normas e diretrizes e a inedequação da estrutura de gestão.

Algumas décadas após a criação do Parque, houve a criação de outra área protegida, com foco no ordenamento espacial marinho, que trouxe em sua constituição novas nuances no processo de gestão e manejo dos recursos naturais direcionadas à maior e mais efetiva abrangência dos aspectos socioculturais locais. Como será aprofundado na seção seguinte, a APAMLN chega ao território em 2008, representando a formação de um mosaico de APs, cuja cobertura se estende à todos ecossistemas da região.

\section{3. ÁREA DE PROTEÇÃO AMBIENTAL MARINHA DO LITORAL NORTE} Limítrofe ao Núcleo Picinguaba, formando um mosaico de áreas protegidas (Figura 2), a Área de Proteção Ambiental Marinha do Litoral Norte possui uma abrangência aproximada de 316 mil hectares e cobre desde a preamar (maré mais alta) até a isóbata (na cartografia, linha imaginária que representa pontos com a mesma profundidade no relevo submarino) máxima de 50 metros (SÃO PAULO, 2008; SÃO PAULO, 2012). 


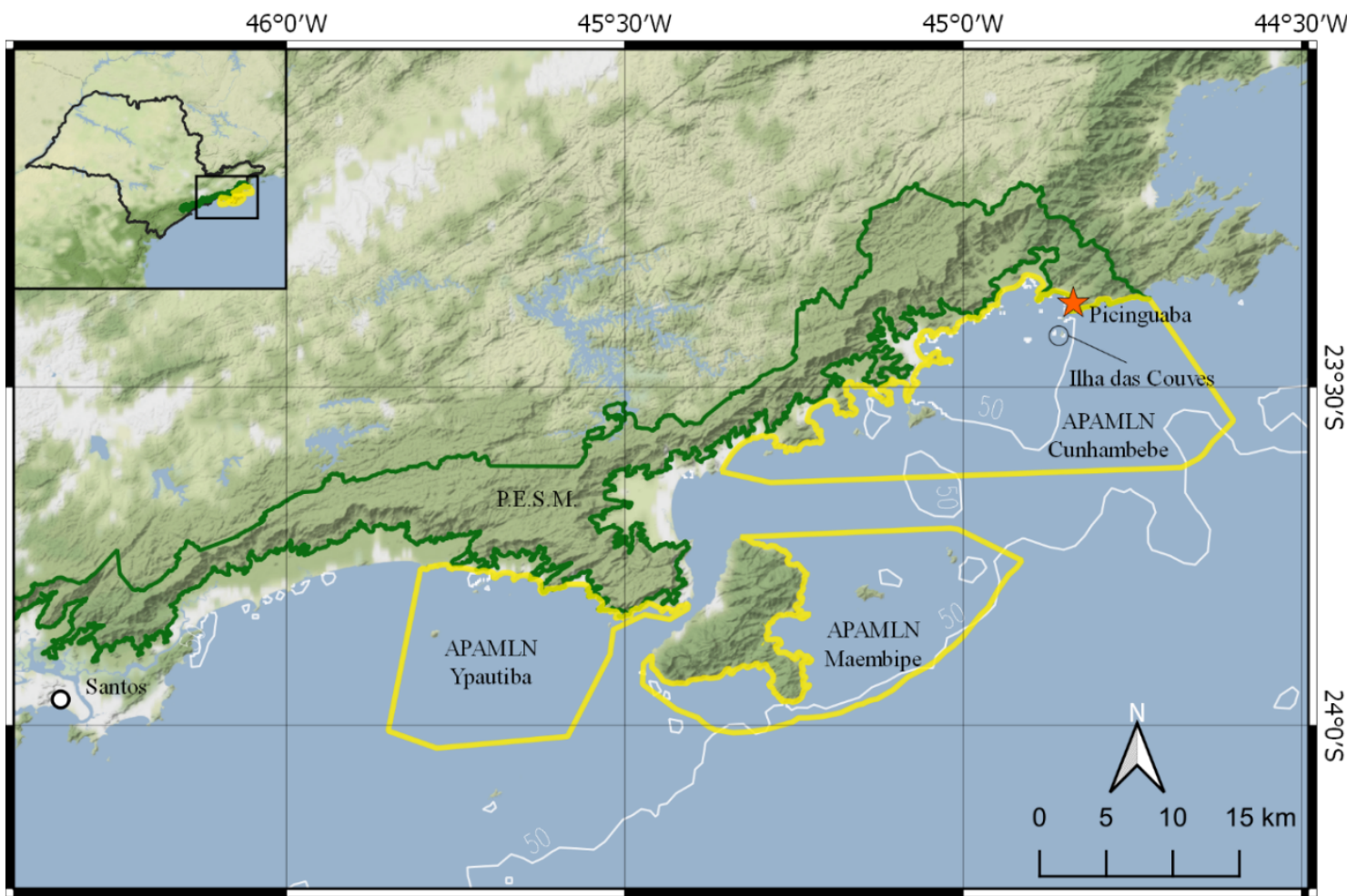

Figura 2. Localização da área de estudo. Polígono verde delimitando o Parque Estadual da Serra do Mar; polígonos amarelos indicando a Área de Proteção Ambiental Marinha do Litoral Norte - Setor Ypautiba, Maembipe e Cunhambebe; marcações laranja e preta indicando Vila de Picinguaba e Ilha das Couves, respectivamente. Linha branca representa a batimetria, linha branca contínua indica a isóbata de 50 metros. Fonte: elaborado pela autora no software QGIS.

A unidade, criada em 2008, encontra-se subdividida em três setores: Cunhambebe, localizado nos municípios de Ubatuba e Caraguatatuba com uma área de 145 mil hectares; Maembipe, que constitui-se numa área de 90 mil hectares em Ilhabela; Ypautiba, ocupando 80 mil hectares na cidade de São Sebastião. O Setor Cunhambebe se sobrepõe a outras unidades de conservação e a zonas de amortecimento ${ }^{11}$, como o Parque Estadual da Ilha Anchieta. Além disso, estão inseridas ao setor as Áreas de Manejo Especial (AME), os manguezais, associados a mais de 15 rios, e ilhas de importante interesse turístico como a Ilha do Mar Virado e a Ilha das Couves (SÃO PAULO, 2012), esta última se configura como área de estudo dessa pesquisa.

11 "Entorno de uma unidade de conservação, onde as atividades humanas estão sujeitas a normas e restrições 
Áreas Ambientais Protegidas (APA) estão associadas a unidades de uso sustentável, estabelecidas pelo SNUC com o objetivo de "compatibilizar a conservação da natureza com o uso sustentável de parcela dos seus recursos naturais" (SNUC, 2000, não paginado). Essas unidades possuem em seu cerne maior flexibilidade, o que as permitem abranger a permanência e usos diretos tradicionais ou não tradicionais. Destaca-se também que podem ser constituídas em partes ou totalmente por terras privadas.

A Área de Proteção Ambiental é uma área em geral extensa, com um certo grau de ocupação humana, dotada de atributos abióticos, bióticos, estéticos ou culturais especialmente importantes para a qualidade de vida e o bem-estar das populações humanas, e tem como objetivos básicos proteger a diversidade biológica, disciplinar o processo de ocupação e assegurar a sustentabilidade do uso dos recursos naturais (SNUC, 2000, Art. 15).

De acordo com Nascimento (2013), ao se instituir uma APA não se alteram as questões de domínio de terras, entretanto há um disciplinamento das propriedades e dos manejos de recursos realizados na área. Esse processo torna-se nebuloso quando passa a envolver comunidades tradicionais considerando que, segundo Dumora (2006), por diversas vezes observa-se que o desenvolvimento sustentável comunitário aparece mais como uma "suplemento ético", pois há uma priorização das causas ecológicas ou advindas dos interesses privados.

Levando em conta as intensas e variadas explorações da costa norte de São Paulo, a instituição da APAMLN se realiza na tentativa de ordenar o "uso racional dos recursos ambientais da região, inclusive suas águas, bem como ordenar o turismo recreativo, as atividades de pesquisa e pesca [...]" (SÃO PAULO, 2008, Art. 1). Além da influência da pesca e turismo no território protegido pela unidade,

A dinâmica recente de transformação socioespacial do LN tem sido impactada em grande parte por conta da implantação de grandes projetos de infraestrutura como a ampliação do Porto de São Sebastião e a duplicação da Rodovia dos Tamoios. Soma-se a este quadro ainda os investimentos realizados pela Petrobras na 
produção e escoamento de petróleo e gás da Bacia de Santos (SÃO PAULO, 2012, p. 4).

Sobre as comunidades caiçaras da região, a APA exerceu influência principalmente em relação à atividade pesqueira. $\mathrm{O}$ ordenamento do uso marinho trouxe proibições consideradas ecologicamente necessárias que afetaram a pesca artesanal em pelo menos quatro tópicos: período de pesca, tipo de rede e técnica utilizada, área explorada e espécies pescadas. Fora isso, a criação da unidade representou o aumento da fiscalização quanto a legalidade dos pescadores, o que trouxe à tona algumas fragilidades da gestão para com as comunidades. Um exemplo é a complexidade do processo de formalização, que envolve desde o processo informativo inadequado sobre a legislação pesqueira até a alta burocracia e demora para se obter a documentação (SÃO PAULO, 2012).

Outra questão importante, abordada por Silva (2020), é que por diversas vezes a determinação do calendário de defeso de espécies não condiz com a realidade.

Segundo pescadores caiçaras, o tempo do defeso nem sempre caminha no mesmo passo do tempo do mar. $\mathrm{O}$ ambiente marinho, incerto e cambiável tem suas possibilidades de uso delineadas por gente que 'não vem estudar o caiçara', 'não vem conhecer a nossa realidade' e que produzem papéis deslocados da realidade (SILVA, 2020, p. 8).

Como forma de superar pelo menos em partes essa questão, há um certo esforço por parte da APA em ampliar a participação de grupos sociais e outros atores para o delineamento de estratégias e ações que se direcionem à alcançar a sustentabilidade dos ecossistemas costeiros e marinhos no litoral norte. Nesse sentido, a unidade desde o ano de sua criação conta com um conselho gestor composto por representantes da pesca, maricultura, turismo e esporte náutico. Também integram o conselho representantes de entidades ambientalistas e de universidades do estado de São Paulo (SÃO PAULO, 2008).

De acordo com Ribeiro (2017), em 2010 se iniciou uma movimentação em prol da elaboração do plano de manejo da APAMLN. Entre criação do plano de trabalho, elaboração de diagnósticos técnicos e participativos, definição de zoneamento e programas de gestão, além das aprovações e devolutivas do conselho gestor, o processo 
de estruturação do plano de manejo se estendeu até o ano presente, encontrando-se no momento em situação de análise pelo Conselho Estadual do Meio Ambiente (CONSEMA).

Como explicado, o PESM e a APAMLN estão sobrepostos à um território tradicional que ainda conta com a presença de uma comunidade que mantém, mesmo que parcialmente, práticas tradicionais do modo de vida caiçara. Apesar de protegerem áreas distintas segundo o entendimento jurídico, sob a visão da comunidade caiçara de Picinguaba, mar e terra se continuam e se completam constituindo um só território. Essa outra significação e apropriação territorial será aprofundada a seguir.

\subsection{HISTÓRIA E CARACTERIZAÇÃO DE PICINGUABA E ILHA DAS COUVES}

Picinguaba foi um sítio de povoamento tradicional de pescadoresagricultores, que em 3 décadas perdeu o mar para a pesca industrial, a terra pela apropriação capitalista do turismo e mais recentemente vive a ambiguidade de ter sido considerada patrimônio histórico e ambiental da cultura caiçara (ÂNGELO, 1992, p. 63).

A história da Vila e do Sertão de Picinguaba ${ }^{12}$ e da Ilha das Couves vêm sendo tecida pela incessante existência e resistência da comunidade tradicional caiçara de Picinguaba. A construção social de suas territorialidades, cujas fronteiras extrapolam delimitações legais, configuram um miscigenado uso e ocupação do território, onde se preserva fragmentos de modos de vidas tradicionais ao mesmo tempo que se assimila imposições procedentes de perspectivas desenvolvimentistas.

A ocupação humana de Picinguaba se deu de forma dividida devido suas característica geomorfológicas, onde curtas planícies litorâneas são brevemente seguidas por declives íngremes da Serra do Mar, o que dificultou esse processo. Deste modo, a população local se distribuiu em dois sítios, a vila e o sertão, ocupando a pequena planície de

\footnotetext{
12 "Reduto de peixes", em tupi-guarani.
} 
sedimentação sucessiva ao mar e diferentes patamares da encosta da Serra (RAIMUNDO, 2007).

A comunidade caiçara local, assim como outras populações tradicionais tanto do litoral quanto do interior, até certo ponto garantiu sua subsistência por meio de técnicas que possibilitavam uma relação estável com o espaço em que vivia. Seu território se estende da terra ao mar, originando uma diversidade de práticas de subsistência, entre elas a pesca (Figura 3) de cerco e arrasto de praia, a coleta de crustáceos e moluscos em estuários dos rios Fazenda e Picinguaba, e a agricultura. Para a prática agrícola utilizavase o fogo e a rotação de culturas a longo prazo, o que resultou em um mosaico ecossistêmico composto por diferentes estágios sucessionais de vegetação, contribuindo para moldar a biodiversidade atual (ÂNGELO, 1992; VIANNA e BRITO, 1992).

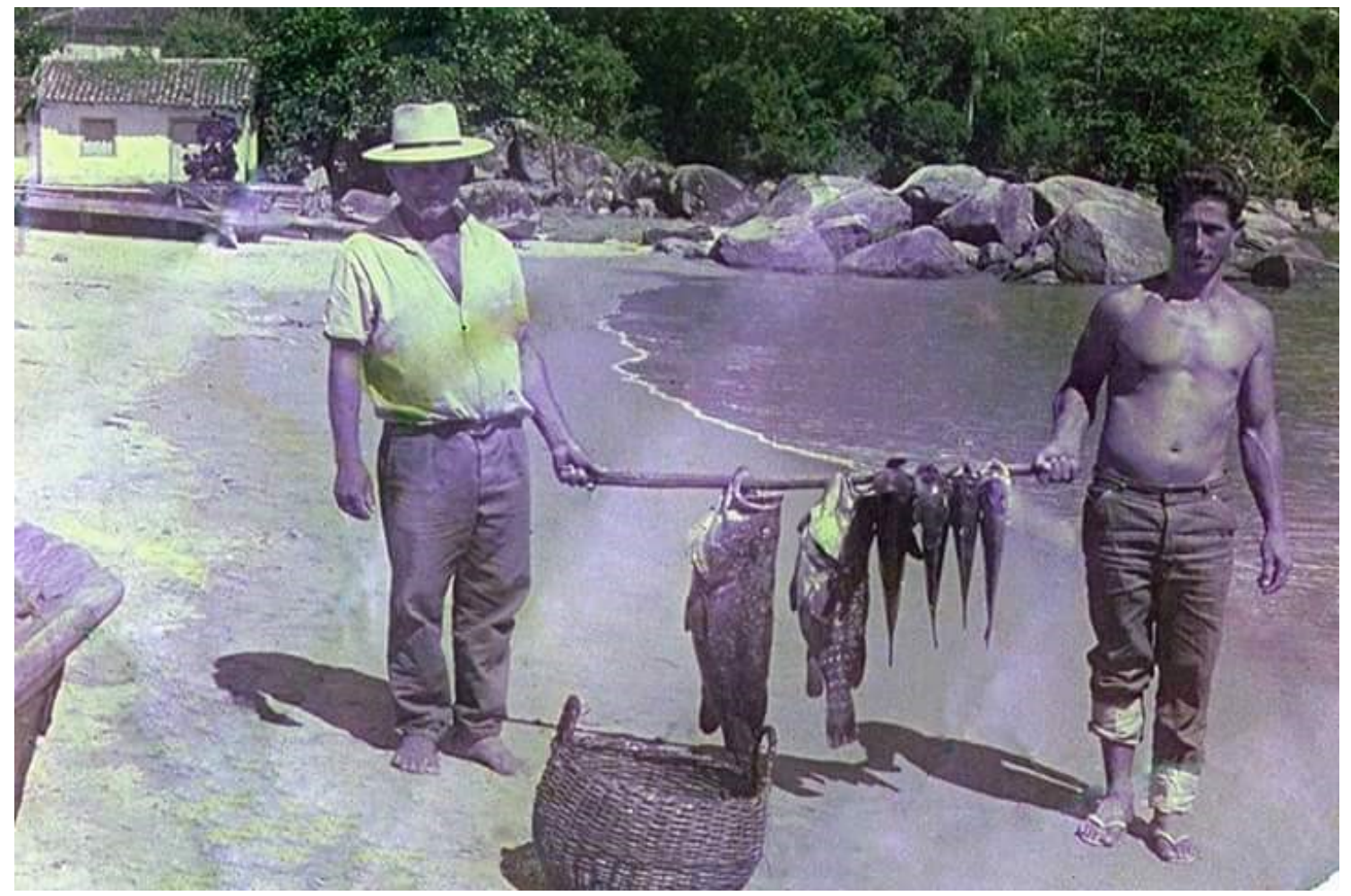

Figura 3. Registro dos anos 1970 de João André e Jonas Marcolino, pescadores tradicionais de Picinguaba. Fonte: AMBP et al., 2019.

Até meados de 1970, a pesca artesanal era praticada com canoas sem motor e a área representava um dos maiores centros de pesca da região. Na década de 1960, o local tornou-se o segundo centro produtor de pescado, sendo Ubatuba o primeiro. Devido à suas boas condições portuárias, a praia de Picinguaba também foi um importante porto de pesca da região. Nesse momento já era sentida a crescente investida da pesca industrial, 
porém a maioria dos caiçaras se mantiveram na pesca artesanal. Mesmo assim, Picinguaba foi o principal ponto de recrutamento de jovens por embarcações industriais o que, como já foi apontado, contribuiu para a descaracterização da comunidade caiçara (ÂNGELO, 1992).

A chegada da BR-101 estabeleceu interconexão entre centros urbanos e o território tradicional de Picinguaba. Rodovia e bairro são interligados por uma estrada vicinal de aproximadamente 3 quilômetros. Por todo esse trajeto é possível observar o ambiente antropizado concebido pelos efeitos históricos da invasão turística (COPELLI, 2015). Segundo Raimundo (2008), a pressão imobiliária forçou algumas famílias caiçaras a deixarem a orla e migrarem para áreas mais próximas a Rio Santos, normalmente menos valorizadas. Esse cenário foi intensificado após o revestimento da estrada.

A pavimentação da estrada que liga a BR-101 à Vila de Picinguaba melhorou os acessos, reduzindo o tempo de percurso e acidentes, o que acabou refletindo na valorização dos terrenos da orla nessa vila. [...]. A pavimentação desta vicinal reforçou a função da vila como espaços de veraneio e de turismo. E a função de conservação, atribuída ao Parque, ficou subordinada àquela função de veraneio e turismo, dentro dos limites da vila, pois as ações de fiscalização não conseguiram reduzir ou coibir as ocupações mais intensas a partir da década de 1980 (RAIMUNDO, 2008, p. 22).

Além das famílias que se realocaram, houve também diversos caiçaras que foram embora de seu próprio território. A presença de turistas e residentes não tradicionais gerou conflitos que permeavam e ainda permeiam a elevada geração de lixo, omissão da prefeitura quanto a saneamento básico, saúde e transporte e pressão por venda. Além disso, destaca-se que houve alteração na arquitetura da vila que até então seguia padrões culturais caiçara (Figura 4). Houve o aumento de construções e estas são rodeadas por muros (Figura 5), diminuindo bruscamente o espaço local e impossibilitando muitas vezes o livre trânsito de antigos moradores (ÂNGELO, 1992). 


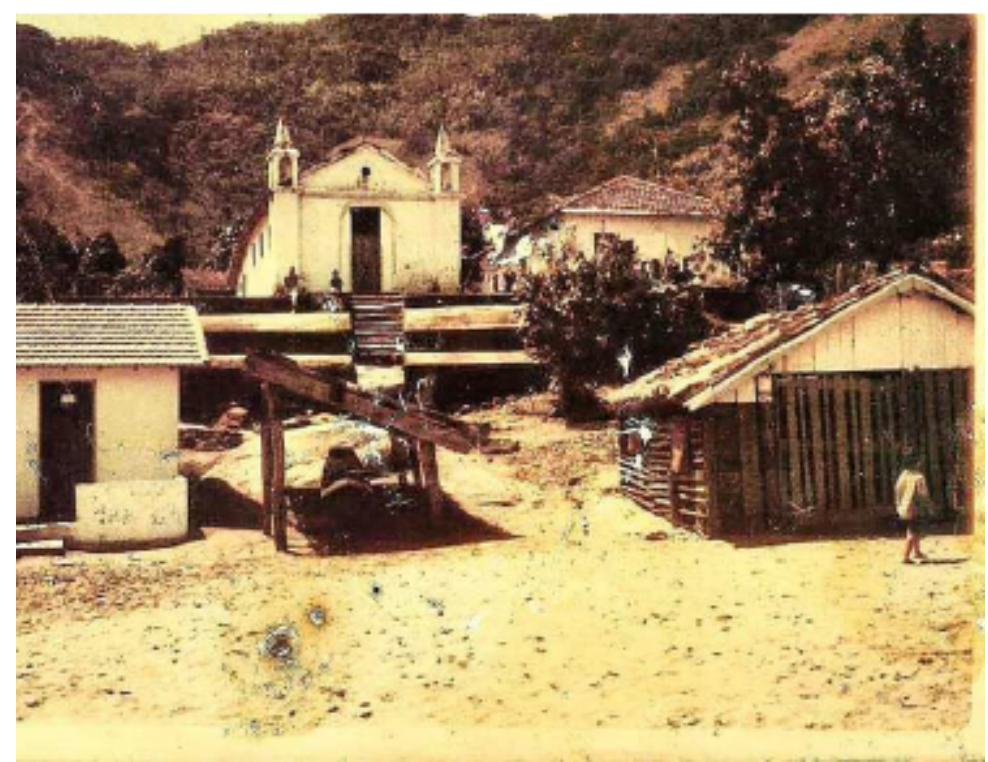

Figura 4. Vila de Picinguaba nos anos 1980. Fonte: AMBP et al., 2020.

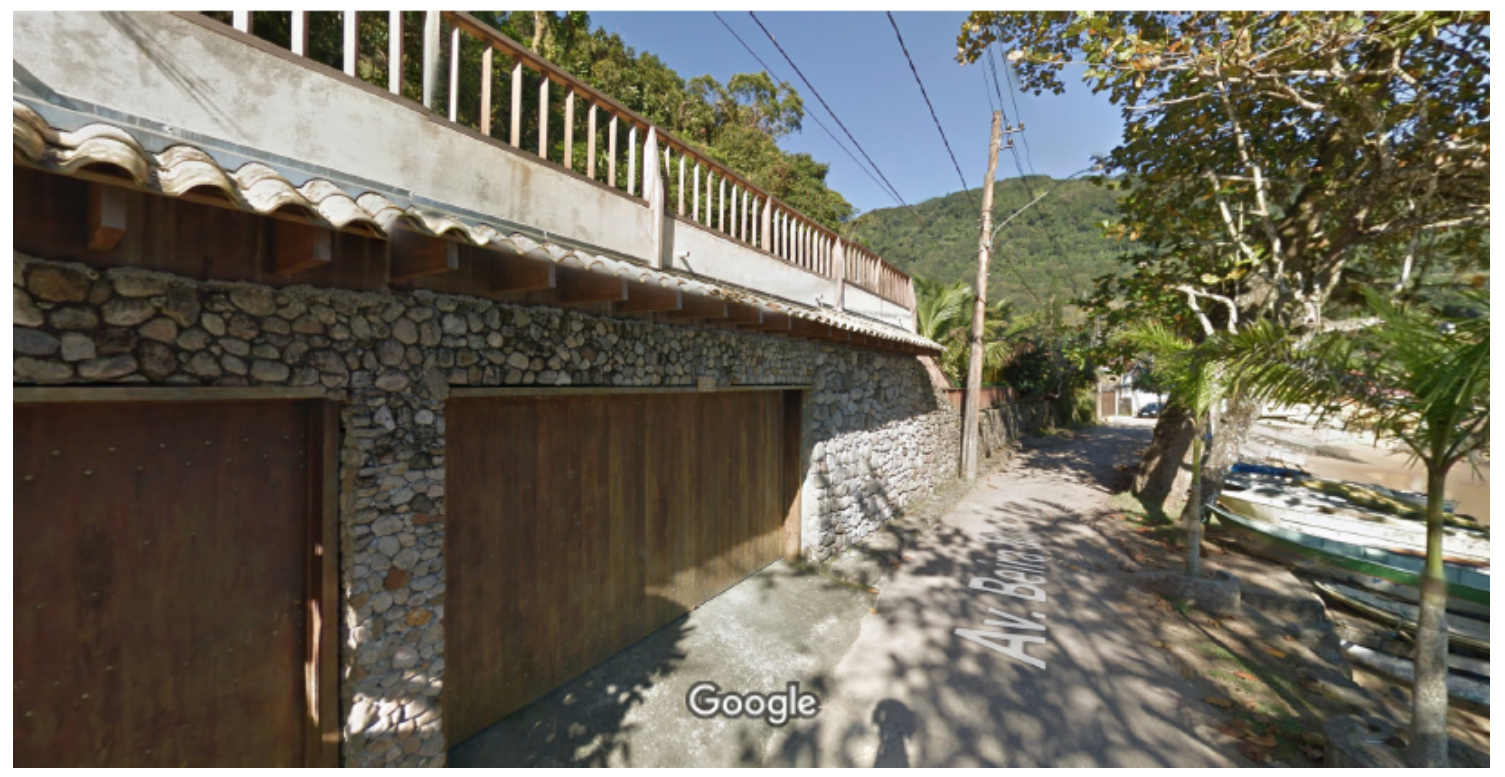

Figura 5. Vila de Picinguaba em 2011. Foto de uma das maiores construções muradas do território. Fonte: Google Maps, 2020.

Em 1983, Picinguaba e as ilhas, ilhotes e lajes do entorno foram tombados como patrimônio histórico cultural do conjunto de interesse arquitetônico e paisagístico pelo CONDEPHAAT ${ }^{13}$, baseado nos seguintes aspectos: a) a comunidade de Picinguaba representa uma das últimas a conservar tradições caiçaras e técnicas da arquitetura vernacular; b) o aglomerado humano que pretende-se preservar está intrinsecamente

${ }^{13}$ Conselho de Defesa do Patrimônio Histórico, Arquitetônico, Artístico e Turístico. 
condicionado pela paisagem da área; c) é de extrema importância a preservação total da bacia hidrográfica local; e d) é de extrema importância a preservação do conjunto de ilhas próximas a Picinguaba, vista a dependência da comunidade pelo mar (CONDEPHAAT, 1985).

O objetivo de preservar "algumas aldeias caiçaras como representativas de uma forma de assentamento humano que faz parte integrante da história do povoamento paulista e que está ameaçada de rápida extinção" (SÃO PAULO, 1998 apud SIMÕES, 2010, p. 86) de certo modo fracassou. Ângelo (1992) destaca alguns pontos que contribuíram para seu fracasso: não envolveu a participação direta dos caiçaras; não foi efetivo em controlar a descaracterização da vila; e não foram implementadas políticas e incentivos para a autoorganização comunitária. Contudo, é importante pontuar que o tombamento foi relevante em reconhecer o território tradicional de Picinguaba de forma integral, envolvendo a parte terrestre e insular (AMBP et al., 2020).

Dentre as ilhas citadas no decreto de tombamento, a Ilha das Couves representa uma das principais para o território tradicional caiçara de Picinguaba. Com uma área de 58 hectares, a Ilha se encontra a aproximadamente 2 quilômetros da praia de Picinguaba e trata-se de uma formação rochosa ígnea, onde $20 \%$ do perímetro é formado por faixa arenosa, e $80 \%$ da área por cobertura vegetal, sendo a maior parte vegetação arbórea densa, característica do bioma Mata Atlântica (VIEITAS e ALMEIDA, 1995; SÃO PAULO, 2012). O local conta com duas praias, a Praia de Terra e a Praia de Fora.

De acordo com Vieitas e Almeida (1995), a relação entre os caiçaras de Picinguaba e a Ilha das Couves se deu por meio do desenvolvimento da pesca e da agricultura. O local também possuía uma casa de farinha, onde era produzido farinha de mandioca, e casas de moradia para algumas famílias. No início da década de 1990, a Ilha foi concedida a um empresário para o usufruto particular, resultando na proibição de uso por parte da comunidade. Apenas uma família continuou ocupando a área, porém atuando então como caseiros contratados pelo proprietário. Após a saída deste empresário, a família permaneceu cuidando da Ilha, onde passou a fazer o manejo de maricultura e abriu o único restaurante do local para trabalhar com o turismo (AMBP et al., 2019). 
Ainda que o território de Picinguaba tenha assumido o turismo como principal atividade econômica, faz-se necessário ressaltar que muitas práticas culturais ainda se fazem presentes.

Contudo, é importante destacar que as funções agrícolas e pesqueiras dos caiçaras não foram eliminadas da paisagem. Elas se mantêm na região de maneira subordinada à função turística e de veraneio, seja em sua materialidade com o fornecimento de insumos aos turistas e pousadas e restaurantes, seja em seu caráter simbólico, também consumido como mercadoria nas trocas culturais com os turistas (RAIMUNDO, 2007, p. 140).

Em mapeamento (Figura 6) mais recente dos diversos manejos dos recursos naturais e usos de Picinguaba, é possível entender que ainda há uma ampla influência nos modos de criar, fazer e viver caiçara.

\section{USOS MÚLTIPLOS DO TERRITÓRIO CAIÇARA DA PICINGUABA}

- Moradia;

- Área de cultivo nos quintais;

- Pesca artesanal (cerco, emalhe, espinhel, zangarelho, linha, apinéia, etc.);

- Maricultura familiar na Ilha das Couves (vieira e marisco);

- Ranchos de pesca e comercialização de peixe;

- Turismo (travessia de barco, aluguel de casa, stand-up e caiaque, e estabelecimentos);

- Festejo caiçara e corrida de canoa.

Figura 6. Mapeamento dos usos caiçaras do território marinho, insular e terrestre. Fonte: AMBP et al., 2019.

Há alguns anos, desde meados de 2016, o território vem vivenciando uma alta intensificação turística que tem refletido na transformação social, cultural e ambiental da área e de seus habitantes. Essa intensificação foi acompanhada por um aumento da ofensiva do setor turístico, que passou a explorar o local de outros meios e com maior extensão. Os conflitos gerados desse movimento resultaram na atenção do Ministério Público Federal, passando a intervir e pressionar uma articulação da comunidade e outros atores para que alternativas àquele cenário fossem pensadas e aplicadas. A partir disso, 
representando o foco de análise do deste estudo, um processo direcionado ao regramento e gestão coletiva do uso público passa a se construir.

\section{RELEVÂNCIA DA PESQUISA}

O pensar sobre uso público em áreas protegidas traz em si uma infinidade de conceitos, constituintes e possibilidades que o torna incapaz de ser concebido sem que se lide pelo menos com uma parte deles. Essa complexidade se justifica se compreendermos que pelo decorrer da história civilizatória, a territorialização dos espaços sempre foi permeada por divergências e oposições, que - para o bem ou para o mal - impulsionaram o processo de coevolução entre natureza e sociedade.

Fazendo o recorte analítico para a área de estudo deste trabalho, os diálogos e confrontos entre as multiterritorialidades que ali se impõem, remetem a três questões que extrapolam os limites do território tradicional de Picinguaba, fazendo-o ainda mais importante como a unidade constituinte de um todo.

1) Falar sobre territórios da Mata Atlântica é falar sobre a segunda maior floresta pluvial tropical do continente americano, cuja biodiversidade é uma das mais ricas do planeta, mesmo que já tenha sofrido uma perda de mais de $90 \%$ de sua área. Segundo dados do INPE (2014), nos últimos 28 anos esse bioma perdeu mais de 1.850 .896 hectares, restando apenas $8,5 \%$ de remanescentes florestais acima de 100 hectares, dentre os quais a área do PESM representa um dos maiores ainda existentes. Scarano e Ceotto (2015) apontam que a região onde se insere a Mata Atlântica no sudeste brasileiro é o principal motor econômico do país, entretanto a distribuição da riqueza e dos danos gerados é altamente desigual, resultando em elevados níveis de pobreza de comunidades que vivem no domínio do bioma. Este cenário se potencializa pela interação perversa entre pobreza e deflorestamento com as mudanças climáticas. A atenuação dos serviços ecossistêmicos intensifica a conjuntura climática que, num efeito rebote, incide diretamente sobre a saúde das matas, do mar e na disponibilidade de recursos naturais para as comunidades.

2) Há alguns séculos o Brasil vêm vivenciando uma intensa perda de sua diversidade cultural através do etnocídio e genocídio de populações tradicionais e suas culturas. A ameaça ao patrimônio cultural imaterial, 
atualmente, se faz ainda mais intensa às comunidades que não possuem tanta notoriedade na mídia e no poder público e são juridicamente pouco protegidas, como é o caso das culturas marítimas. Segundo Santos (2013), as áreas litorâneas brasileiras que ainda abrigam populações tradicionais que guardam parte de suas tradições são escassas. Entretanto, há uma obscuridade quanto a situação real dessas comunidades devido a escassez de dados, o que as coloca em posição ainda mais frágil.

3) O turismo de massa se impõe na contemporaneidade como uma das principais atividades econômicas responsáveis pela degradação cultural e ambiental. A atividade se tornou um dos pilares na recuperação da economia do Brasil, registrando um aumento no faturamento de mais de 8\% entre 2018 e 2019 (BRASIL, 2019). Essa realidade, principalmente no governo atual, vêm sendo cada vez mais incentivada, com o excessivo esforço em transformar áreas socioambientalmente importantes em palco para o turismo de massa, principalmente se estas se encontrarem no litoral.

Como alternativa a esse cenário, territórios que são legalmente protegidos por seu aspecto ecológico, vêm sendo submetidos a modelos de parcerias principalmente direcionados ao setor privado, assunto que será melhor discutido nas seções a seguir. Só no ano de 2020, 27 editais foram publicados autorizando a prestação de serviços em parques nacionais pela iniciativa privada. No estado de São Paulo, desde 2016, cerca de 25 parques vêm sendo mapeados para serem concedidos.

Esse movimento chama a atenção em alguns sentidos: 1) os editais de concessão, de maneira geral, exigem um alto investimento mínimo nas áreas, impossibilitando que organizações do terceiro setor concorram; 2) as comunidades residentes dessas áreas são incluídas por meio da possibilidade de preencherem trabalhos assalariados no turismo; 3 ) há declaradamente o objetivo de se estimular quantitativamente o turismo, tornando essas áreas mais atrativas financeiramente, mesmo que isso não dialogue com os objetivos de uso público e de conservação delineados pelo SNUC.

Nesse sentido, há um esforço em se delinear alternativas a este modelo que de fato compreendam a emergência socioambiental, priorizando a saúde e longevidade dos espaços naturais e comunidades associadas. É sob essa perspectiva que esse trabalho se 
coloca, representando um esforço em fortalecer e corroborar com alternativas que não só envolvem, mas possibilitem o protagonismo de comunidades tradicionais no uso público de áreas protegidas.

Pesquisar o processo de ordenamento e gestão comunitária do turismo no território tradicional de Picinguaba permite alcançar uma compreensão sobre o que envolve e do que dependem essas alternativas. É importante destacar que para além do recorte turístico, o trabalho corrobora para fundamentar o fortalecimento do diálogo entre órgãos gestores, comunidades e demais parceiros, compreendendo os alcances e limitações no desenvolvimento de gestões mais democráticas e participativas dessas áreas.

À vista do que foi refletido, essa pesquisa foi norteada por algumas perguntas entendidas como centrais para que os objetivos fossem alcançados: sob qual narrativa esse arranjo comunitário para o desenvolvimento do uso público foi desenvolvido? Como a gestão comunitária do turismo contribui para que os objetivos das APs em questão sejam melhores atingidos? Quais os esforços e atores necessários para que haja o manejo efetivo dos conflitos entre áreas protegidas e comunidades que as habitam? Quais os instrumentos, institucionais ou não, foram necessários para a concretização dessa parceria? Como essas articulações reverberam em outras dimensões do território?

\section{OBJETIVO}

\subsection{OBJETIVO GERAL}

Analisar a gestão e ordenamento comunitário do turismo como estratégia para o manejo dos conflitos socioambientais ocasionados pela atividade em territórios que abrangem áreas protegidas.

\subsection{OBJETIVOS ESPECÍFICOS}

- Compreender os conflitos sociais, ambientais e econômicos decorrentes do uso turístico desordenado da Ilha das Couves; 
- Mapear os atores, instrumentos e ações realizadas durante o processo de ordenamento, bem como as responsabilidades conferidas para cada ator identificado;

- Compreender como o turismo de base comunitária atua para a mitigação dos problemas socioambientais do território e para a potencialização da efetividade das APs em questão.

\section{REVISÃO DA LITERATURA}

A questão ambiental coloca-se na contemporaneidade como uma problemática que demanda discussões mais sistêmicas. Se partimos do conceito geral de sistemas, a natureza integra um sistema aberto, formado por unidades elementares dependentes entre si, o que faz a complexidade inerente à sua compreensão. Sobre a complexidade de um sistema, Edgar Morin aponta:

A um primeiro olhar, a complexidade é um tecido (complexus: que é tecido junto) de constituintes heterogêneas inseparavelmente associadas: ela coloca o paradoxo do uno e do múltiplo. No segundo momento, a complexidade é efetivamente o tecido de acontecimentos, ações, interações, retroações, determinações, acasos, que constituem nosso mundo fenomênico (MORIN, 2006, p.13).

Ao se pensar a conservação de áreas naturais é preciso considerá-las antes parte de um sistema onde há a expressão de valores e interesses distintos. Políticas públicas voltadas à proteção ambiental, desde seus primórdios no século XIX, carregam com si conflitos oriundos de um paradigma teórico e político que entende a interação homemnatureza não só como nociva, mas como não-orgânica. A materialização dessa visão puramente preservacionista se deu principalmente através do cercamento de inúmeras parcelas ambientais pelo Estado, dando origem as áreas protegidas (APs) (CIOFFI e RAIMUNDO, 2020). 
Para Morin (2006) "a complexidade se impõe primeiro como a impossibilidade de simplificar." Ao se assumir apenas o prisma ecológico e estético na gestão de áreas protegidas, originaram-se contextos cujos conflitos, de acordo com Lewis (1996), transpassam duas principais questões: 1) a ausência da participação de comunidades locais e outros atores no processo de planejamento, gestão e decisão; 2) a proibição de atividades tradicionais do modo de vida de certas populações, como caçar, plantar ou pescar.

Apesar das tensões ameaçarem constantemente a efetividade das APs, elas não necessariamente ecoam como algo negativo, considerando que são expressões do sufocamento histórico da multidimensionalidade concebidas a partir destes espaços. $\mathrm{O}$ que se observa nesse movimento, dado um contexto de globalização econômica, é a intensificação do questionamento acerca do papel regulador do Estado acompanhado da imersão de um conceito-chave que vem reverberando não só no debate acadêmico como também nas ações públicas que compreendem uma diversidade de processos e segmentos sociais, a governança ambiental.

De acordo com Zhouri (2008, p.97),

Governança aparece como uma categoria-chave no campo semântico que recobre a discussão sobre desenvolvimento sustentável, alinhada a outras como negociação, participação, parceria, sociedade civil organizada etc.

O conceito ganha força ao integrar uma noção de abrangência que incorpora diferentes ideias, significados e atores não estatais, se baseando em uma multiplicidade de objetivos públicos e privados que fluem e dialogam entre si (JACOBI e SINISGALLI, 2012).

A governança ambiental, em toda sua amplitude, se constrói em uma diversidade de domínios que envolvem conceitos, interpretações e práticas que juntos compõem todas e cada uma das deliberações direcionadas ao meio ambiente. À vista disso, nos encaminhamos a aprofundar o debate sobre governança para posteriormente apresentar alguns conceitos e estratégias integradas à ela que norteiam na contemporaneidade grande parte da discussão sobre manejo e gestão de áreas protegidas. 


\subsection{GOVERNANÇA AMBIENTAL}

A abstração a respeito de governança se tornou mais robusta principalmente a partir dos anos 1990, até então a palavra correspondia ao sentido de "governar". Com um deslocamento das abordagens das ciências sociais e políticas públicas, cuja tendência se direcionava para uma autogestão nos campos social, econômico e político, a governança incorpora a ideia de mudança no modo de gestão política, tornando-se um conceito mais amplo. Logo, ao falar sobre governança fala-se também sobre modelos de governo menos ou não-hierárquicos, nos quais há uma participação intensa da sociedade civil na formulação e implementação de políticas públicas (JACOBI e SINISGALLI, 2012; KISSLER e HEIDEMANN, 2006).

Os princípios da governança baseiam-se em um novo entendimento sobre o Estado, que passa a assumir o papel de agente de governança ao mesmo tempo que flexibiliza a ideia de protetor do bem comum. Nessa nova ressignificação identificam-se três fases: 1) de um Estado produtor do bem público a um que garante a produção deste; 2) de um Estado ativo a um ativador, que mobiliza e coordena outros atores a agir com ele; 3) de um Estado dirigente a um cooperativo (KISSLER e HEIDEMANN, 2006).

O modo extenso com que o significado de governança vêm sendo tratado deve-se em grande parte a ascensão de concepções neoliberais. Empregando um discurso "socialdemocrata de cunho neoliberal", enfatiza-se a necessidade de modernização da forma de gestão do setor público, tendo como caminho principal a diminuição do Estado. Essa lógica induz a transição estatal, que por meio de privatizações, terceirizações e parcerias público-privadas (PPP), assume por diversas vezes caráter de empreendimento econômico (KISSLER e HEIDEMANN, 2006; FREY, 2007).

Em paralelo a abordagem neoliberal de governança, há também uma outra vertente que trata da reforma estatal fundamentada em uma aproximação democráticoparticipativa, cujo objetivo é reestruturar os instrumentos de decisão de modo a aumentar o envolvimento popular. Neste sentido, de acordo com Graham et al. (2003), uma "boa" governança constrói-se com os seguintes princípios: legitimidade e voz, expressas na gestão descentralizada e na criação de fontes informativas independentes; administração efetiva amparada por um plano de manejo abrangente e participativo; bom desempenho, 
estruturado na aplicação, monitoramento e adaptação se necessário; prestação de contas; e justiça, apoiando-se a uma base legal, a gestão deve ser justa e imparcial.

Ainda segundo Graham et al. (2003) o conceito de governança pode ser impresso sobre qualquer modelo de ação coletiva. Assim, os autores apontam quatro áreas em que este conceito tem significativa relevância: o "espaço global", extrapolando o alcance de governos individuais; o "espaço nacional”, que envolve os vários níveis de governo de um país; o "espaço da organização", compreendendo organizações privadas ou públicas com conselhos legais de administração; e "espaço da comunidade", inclui ações em locais cujo âmbito organizativo não é por vezes formalmente constituído.

Ao se importar a ideia de governança para a questão ambiental, passou a ser visto lacunas nas estruturas de poder responsáveis por políticas direcionadas à natureza. Notadamente, há um entendimento que as consequências da exploração predatória não serão mitigadas se não houver um esforço em se encontrar pontos de convergências entre os interesses de múltiplos atores que atuam sobre um território. Este debate tem reverberado pelas diferentes esferas que compõem o corpo da política ambiental brasileira, inclusive se tratando de áreas protegidas, que vem experimentando novos modelos e estruturas de governança (JACOBI e SINISGALLI, 2012; GRAHAM et al., 2003).

A noção de governança participativa conecta-se inevitavelmente a uma nova forma de construção territorial. O controle zonal ${ }^{14}$ dá espaço na contemporaneidade para uma dominação em rede, engendrando novos arranjos de poder e dando forma a multiterritorialidade. A redistribuição do poder aos múltiplos âmbitos que produzem o território significa também um avanço para a democratização do acesso aos recursos naturais comuns. Por outro lado, destaca-se que ainda há uma sólida hierarquia nestes

\footnotetext{
${ }^{14}$ A pluralidade territorial, reforçada na contemporaneidade, vêm mostrando uma separação gradual entre duas principais lógicas de controle, a zonal e a territorial reticular. A zonal, sob a qual se fundou hegemonicamente o mundo moderno capitalista, tem o Estado como controlador de fluxos em fronteiras precisamente delimitadas, e intenciona uma unidade territorial, onde há a admissão de apenas uma forma de domínio. A territorial reticular, rompendo com a lógica da modernidade, se impõe com novos circuitos de poder consequentes da formação de territórios-rede (HAESBAERT, 2007).
} 
novos moldes de gestão, onde há o favorecimento de certos atores em detrimento de outros (ACSELRAD, 2002).

A diluição do poder sobre um território encontra-se com um cenário de reivindicação de uso de espaços naturais que em determinados tempos históricos tornaram-se áreas protegidas. $\mathrm{O}$ amadurecimento destas áreas junto às diferentes possibilidades de gestão vem resultando em uma mudança no paradigma da conservação, no qual o uso passa a frequentemente ser entendido como potencial aliado. A partir disto, novas arenas formais de negociação são instituídas, onde sujeitos e/ou organizações podem trazer suas contribuições e estabelecer redes de diálogo e atuação, configurandose assim instâncias efetiva de administração (COZZOLINO et al., 2015).

Hulme e Murphree (1999), na tentativa de interpretar o mainstream da conservação contemporânea, sugerem três principais vertentes que o norteiam e são tecidas de maneira distinta em estruturas conceituais, políticas e práticas. A primeira refere-se ao comunitário e se baseia na transferência em menor ou maior grau da gestão e direito de propriedade para comunidades em níveis locais; a segunda, sustentabilidade, origina-se da ideia de desenvolvimento aliado à conservação; por último há a vertente que se funda do pensamento neoliberal e acredita numa maior exposição do meio ambiente ao mercado.

Conforme Dinica (2017a), a governança relativa a APs se pronuncia em uma variedade de arranjos institucionais que envolvem instrumentos legais, políticos e administrativos para a colaboração entre a esfera pública e privada, onde são expressas influências das diferentes vertentes na conservação. Por meio desses arranjos, segundo Rodrigues e Abrucio (2019), órgãos públicos formam parcerias com diferentes segmentos da sociedade que contribuem para gestão e desenvolvimento de diferentes práticas que envolvem o alcance dos objetivos definidos para uma área protegida.

Os arranjos tradicionais de governança de maneira geral envolvem a elaboração de instrumentos ligados ao planejamento, regulamentação e gestão de diferentes fases e níveis. Como demonstrado na pirâmide da Figura 7, estes se organizam hierarquicamente em delineamento legislativo, nos âmbitos internacionais e nacionais, definição de estratégias para a proteção ambiental, no caso, por meio da implementação de diferentes modelos de APs, criação de planos de manejo para nortear ações de gestão e por último, 
formação de parcerias pautadas em políticas desenhadas para a sua gestão (DINICA, 2017b).

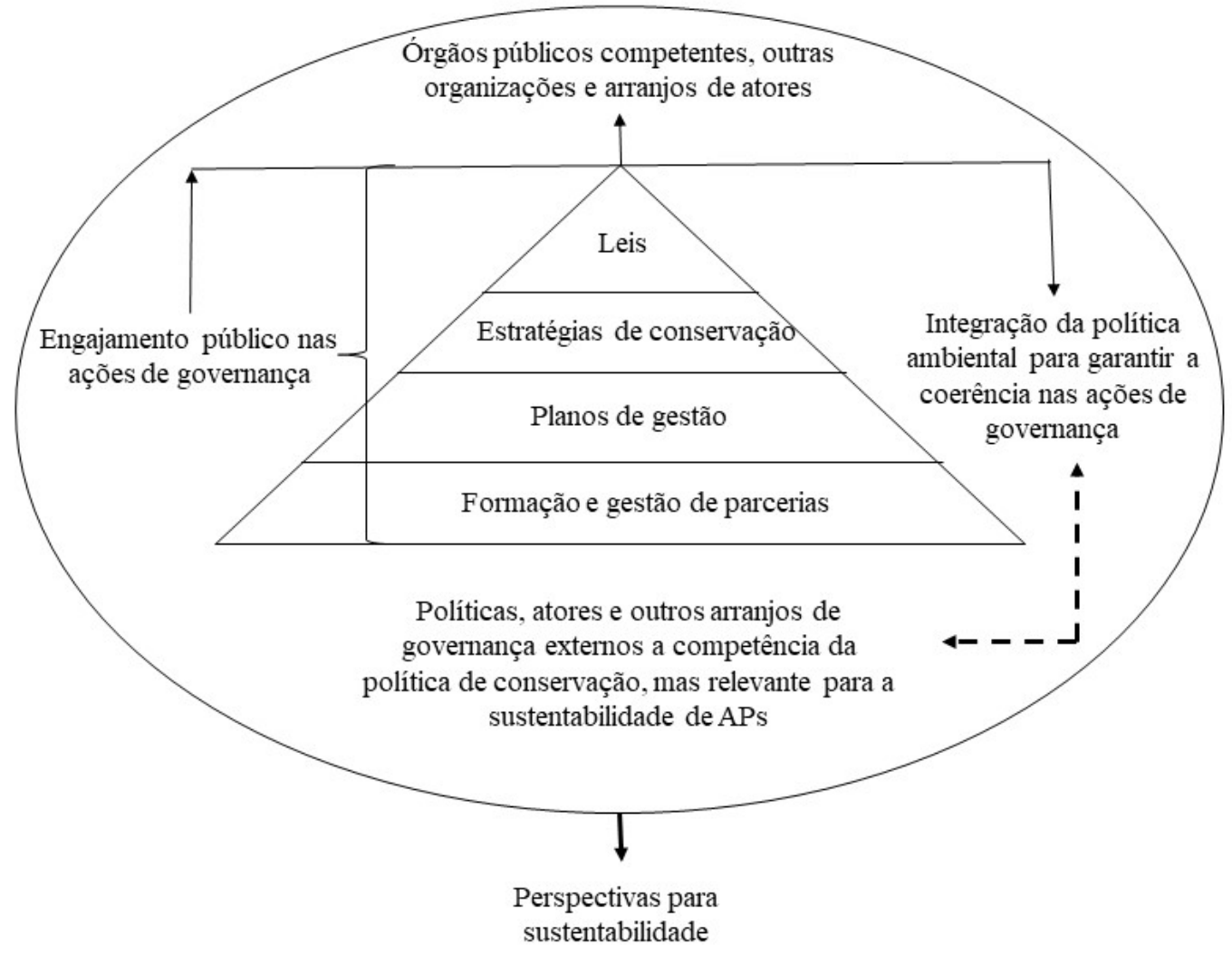

Figura 7. Modelo conceitual de avaliação entre a governança de áreas protegidas, o engajamento público e as perspectivas de sustentabilidade. Fonte: Dinica (2017b), adaptado pela autora.

A decisão e formulação da agenda pública ambiental em seus diferentes níveis depende diretamente da atuação dos atores públicos e privados, cuja articulação se dá de maneira a encontrar um consenso na elaboração de políticas que compreendam ideologias, valores e interesses específicos (KINGDON, 1995). Para Subirats (2006), os valores dominantes são expressados pelos dirigentes políticos e interferem diretamente na decisão política e na criação dos instrumentos de domínio. Nesse sentido, os instrumentos organizados na estrutura hierárquica mostrada na Figura 7 se efetuam ante a diversos acordos entre atores público-privados refletidos nos recursos e ações de governança (DINICA, 2017b).

Dinica (2017b) destaca a essencialidade de dois fatores para uma governança cujo horizonte sustente a possibilidade concreta da sustentabilidade. O primeiro refere-se a 
adoção de ferramentas para a integração de políticas ambientais para o desenvolvimento de abordagens ligadas a um governo mais integrado ${ }^{15}$. A parte inferior da Figura 7 evidencia a dependência da relação entre essas abordagens e âmbitos externos a este domínio. A autora ainda cita como exemplos o campo de decisões orçamentárias para o financiamento de APs ou políticas de energia e transporte.

O segundo fator, o qual receberá mais atenção devido sua importância a este trabalho, trata-se do engajamento público. Apesar de não haver uma definição única e universal, seu conceito aproxima-se da ideia de comunicação, consulta e participação pública. Para Dinica (2017b), seu conceito assume características mais amplas, envolvendo os insumos intelectuais e materiais que as comunidades e organizações tem o direito de oferecer a qualquer ação que interfira nas operações ou estruturas de governança. As possibilidades de envolvimento variam de forma quantitativa e qualitativa influenciando diretamente no equilíbrio ou desequilíbrio de poder na governança ambiental.

A ideia de sustentabilidade alia-se ao conceito de desenvolvimento sustentável, que implica na possibilidade de suprir necessidades das presentes gerações sem que as necessidades de gerações futuras sejam comprometidas. Entretanto, o debate estabelecido em torno deste conceito aponta para apropriações a partir de diferentes perspectivas, sendo a principal delas o progresso capitalista alinhado à práticas ecológicas de menor impacto. A interpretação das últimas décadas mostra que as justificativas sustentáveis foram utilizadas como estratégia para sustentar novamente o modelo desenvolvimentista e não para garantir a diversidade e longevidade da vida natural e social (ESTEVA, 1992).

A sustentabilidade pensada a partir de pespectivas socioambientais direciona-se à um olhar crítico não só ao uso dos dos recursos naturais em si, mas seus reflexos em diferentes grupos sociais que deles dependem. Nesse sentido, estratégias "alternativas"

\footnotetext{
15 A ideia da integração de políticas ambeintais deriva do conceito em inglês environmental policy integration (EPI) que, segundo Jordan e Lenschow (2010, p. 147, traduzido pela a autora), surge pela primeira vez na década de 1990 na tentiva de conectar sistematicamente "os objetivos aparentemente incompatíveis de competitividade econômica, desenvolvimento social e proteção ambiental". Conforme Dinica (2017b) os instrumentos de EPI derivam de apelos por whole-of-government approaches. Para áreas protegidas, ressalta a autora, os instrumentos mais relevantes são avaliações ambientais estratégicas ou de impactos regulatórios.
} 
como proposição para o desenvolvimento sustentável tem sido pautadas com base em referenciais como democracia participativa, controle social e interdisciplinaridade (HANAI, 2012).

A abordagem participativa como parte integrante no desenvolvimento de uma governança com perspectivas sustentáveis corresponde a possibilidade de alcançar um cenário de redistribuição mais igualitária de custos e benefícios.

A participação não se trata apenas de alcançar a distribuição mais eficiente e equitativa dos recursos materiais: trata-se também da partilha de conhecimento e da transformação do próprio processo de aprendizagem a serviço do desenvolvimento pessoal (CONNELL, 1997 apud kiKI, 2008, p. 511, traduzido pela autora).

Okazaki (2008) ao dialogar com Arnstein (1969) aponta que o engajamento público deve evoluir gradualmente em direção a redistribuição de poder e categoriza o que chama de "escada de participação cidadã" em três níveis: a não participação, graus de simbolismo e graus de poder do cidadão. A Figura 8 apresenta oito degraus que diferenciam-se nesses três níveis. Os dois primeiros referem-se a manipulação e terapia nos quais, segundo Tosun (2006), não há um objetivo real de possibilitar o envolvimento público, mas sim há a intenção de "educar" comunidades e organizações para aceitarem interesses dominantes.

Os próximos degraus alinham-se a participações mais simbólicas dos processos decisórios, onde comunidades estão presentes na implementação ou no compartilhamento de benefícios, mas ainda afastadas das posições onde as decisões são concretamente tomadas (TOSUN, 2006). A informação, na qual os cidadãos são informados acerca dos seus direitos, opções e responsabilidades, representa "o primeiro e mais importante passo para o engajamento público legítimo" (OKAZAKI, 2008, p. 513). O quarto degrau diz respeito ao incentivo para que a opinião pública seja expressada como forma de consulta e o quinto, apaziguamento, refere-se ao crescimento da influência pública, mas ainda com altos graus de tokenismo. 
A categoria mais alta na escada de participação cidadã, como demonstrado na Figura 8, indica diferentes graus de poder do engajamento público. Parceria compreende a redistribuição efetiva do poder e das responsabilidades por meio da negociação entre cidadãos e tomadores de decisão. $\mathrm{O}$ degrau seguinte indica a delegação de poder ao público sobre determinado domínio. No último degrau, controle cidadão, há a representação máxima da participação e detenção de poder, em que o cidadão assume o total controle sobre a política e gestão (OKAZAKI, 2008). Conforme Tosun (2006), as abordagens que envolvem graus de poder ao cidadão correspondem a noção de uma participação espontânea, autêntica e ativa de comunidades, onde as decisões passam a assumir características bottom-up.

A possibilidade de uma evolução no nível de participação e engajamento liga-se diretamente à novas formas de gestão de APs de modo a superar certas lacunas que a gestão com altos graus de centralização possuem. À vista disso, esse estudo busca também a compreensão de como o progresso do envolvimento cidadão se dá na prática, mais especificamente no contexto territorial do área de estudo proposta.

A concepção da trajetória que estrutura a ideia da escada de participação e redistribuição de poder possui o foco para níveis internos e verticais de participação dentro de uma comunidade. $O$ avanço desses níveis depende diretamente do fortalecimento e consolidação das relações de base formadas entre "indivíduos similares do ponto de vista de suas características demográficas" (MARTELETO e SILVA, 2004, p. 44). Estes laços associam-se a noção de capital social de ligação (Figura 8).

Este tipo de capital social, associado à existência de relações de confiança, reciprocidade e coesão do grupo, favorece as trocas de informação e, potencialmente, o desenho de estratégias compartilhadas, o consenso sobre normas reguladoras, a promoção da ação coletiva e a gestão dos conflitos internos ao grupo (MERTEN et al., 2011, p. 483) 


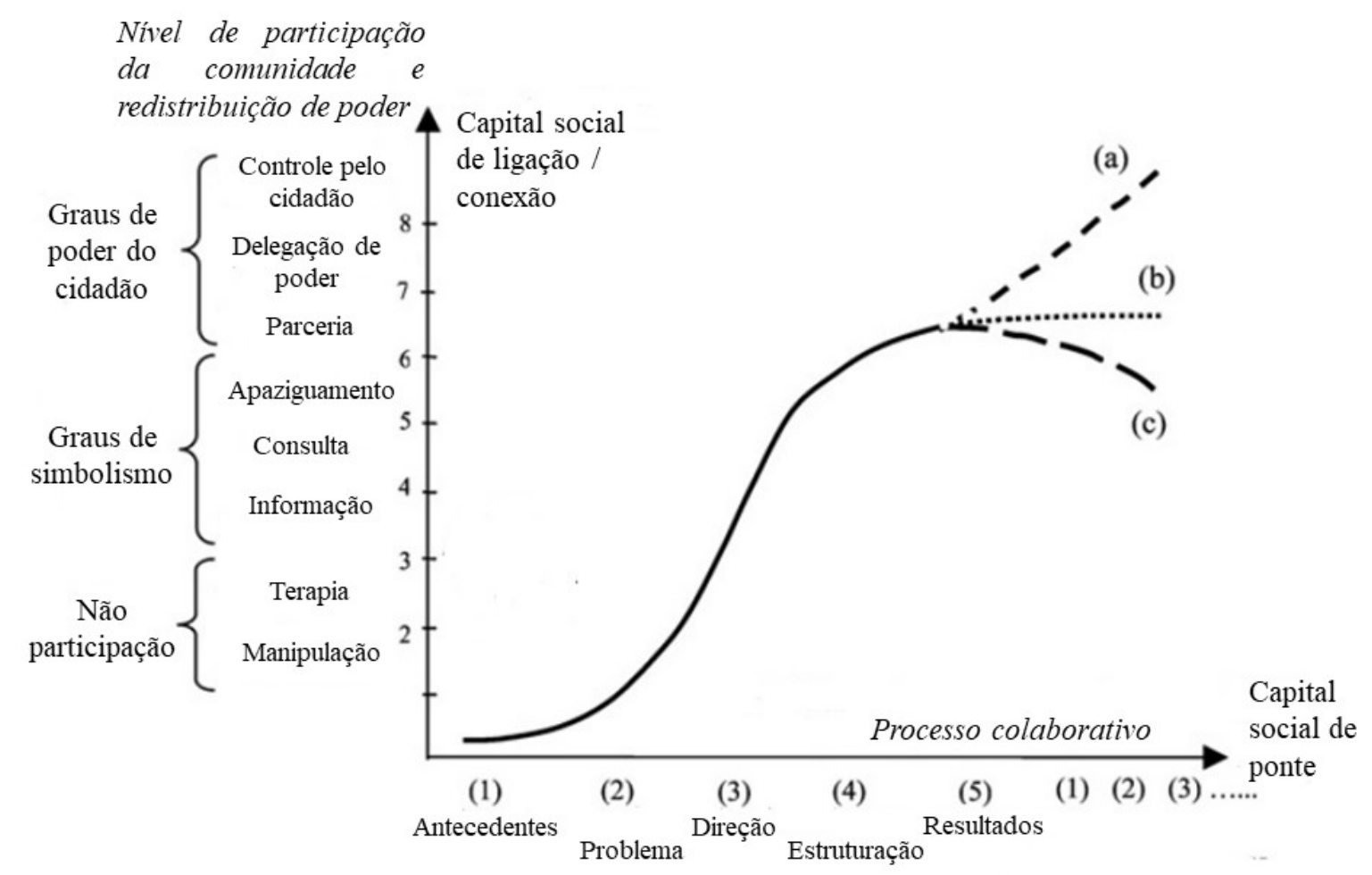

Figura 8. Modelo do processo de Turismo de Base Comunitária. Fonte: Okazaki (2008), adaptado pela autora.

O conceito de capital social em toda sua multidimensionalidade encontrou eco nos campos da governança ambiental, desenvolvimento sustentável e gestão dos recursos naturais. Segundo Marteleto e Oliveira e Silva (2004, p. 44),

O capital social, por sua vez, é definido como as normas, valores, instituições e relacionamentos compartilhados que permitem a cooperação dentro ou entre os diferentes grupos sociais. Dessa forma, são dependentes da interação entre, pelo menos, dois indivíduos. Assim, fica evidente a estrutura de redes por trás do conceito de capital social, que passa a ser definido como um recurso da comunidade construído pelas suas redes de relações.

O robustecimento do capital social de ligação depende em partes de condições políticas, jurídicas e institucionais ligadas a uma visão institucional que interfere na vitalidade e desenvolvimento das redes. Okazaki (2008) rotula a integração com o capital social de instituições formais como capital social de conexão e aponta a necessidade de 
sinergia entre capitais, considerando a competência do Estado em promover recursos adicionais para potencializar o engajamento público.

Dentre as possibilidades de participação no âmbito de APs, o turismo representa a principal atividade para a qual as parcerias estão sendo empregadas. Experimentando uma intensa expansão global nas últimas décadas, a atividade turística assumiu uma importante posição na economia mundial, ampliando geograficamente o setor, abarcando novas demandas do mercado (GRIMM e SAMPAIO, 2011). Segundo Dinica (2017a), o potencial turístico de APs tem alta expressividade, considerando que os Parques Nacionais tornaram-se as principais atrações turísticas do mundo. $\mathrm{O}$ alto interesse turístico também é observado em APs estaduais, como é o caso do território que está em foco neste estudo.

A interface entre o objetivo conservacionista e o uso turístico de APs representa um dos principais desafios para a governança ambiental na atualidade. A abertura de espaço para o desenvolvimento do uso público cria um novo nicho de atuação e também de conflito. A necessidade de planejar e estruturar meios que possibilitem a visitação coloca em debate o estabelecimento de parcerias entre a gestão pública e outras organizações, sejam elas privadas ou da sociedade civil. Neste movimento, se faz presente uma intensa pressão do setor turístico em ocupar este nicho e, por outra parte, há uma movimentação de comunidades tradicionais e/ou locais para reivindicar a prioridade neste processo.

À vista disso, vêm sendo observado uma tendência na governança de áreas protegidas direcionada a adoção de modelos de uso público associados a vertente cujas raízes levam as ideias neoliberais. Por meio de parcerias público-privadas, o Estado concede serviços ${ }^{16}$ para empresas que tenham interesse em explorar as potencialidades turísticas destas áreas. Esse modelo é amparado pelo discurso de que a terceirização da visitação permite a requalificação dos padrões de uso, pois fomentam o uso responsável

\footnotetext{
${ }^{16}$ A concessão de serviços públicos é um instrumento criado inicialmente para transferir a gestão de certos serviços à iniciativa privada, incentivando assim o investimento em áreas como transporte, energia e telefonia. A concessão ocorre por meio de licitação, na qual empresas interessadas concorrem provando sua capacidade de desempenhar a função e assumir os riscos. Quando concedido, a exploração do bem comum é exclusiva ao ganhador da licitação e ocorre por tempo determinado em contrato (RODRIGUES, 2009).
} 
(principalmente através de melhorias na infra-estrutura) e consequentemente, alcançam mais satisfatoriamente os objetivos de proteção (ESTIMA et al., 2014).

Conforme apontado por Estima et al. (2014), o processo concessório é um desafio e sua implementação deve se sustentar em quatro pilares: 1) uma consistência política e jurídica adequada à realidade do local para basear a contratação; 2) viabilidade financeira para concessão demonstrada por estudos; 3) uma prospectiva descrevendo precisamente as melhores práticas para a concessão, abrangendo oportunidades, limitações e métodos de gestão; 4) clareza sobre as responsabilidades ambientais, sociais e econômicas para com a área em questão e seu entorno. Ademais, faz-se necessário apontar em contrato a primordialidade da adoção de práticas ecológicas de mínimo impacto.

A importação da concessão à realidade das áreas protegidas, segundo Ojeda (2012), exemplifica a conexão entre turismo e a dinâmica de apropriação de terras pelo poder estatal e corporativo justificada pelo discurso de desenvolvimento e conservação. A abertura para este modelo de uso público, contribuiu para intensificar a pressão sobre o território e recursos das comunidades locais, prejudicando a possibilidade de assumirem o turismo como meio de subsistência complementar e mais que isso, favorecendo muitas vezes a realocação e expulsão destas. $\mathrm{O}$ autor também aponta como consequência, a transformação do modo como as populações locais interagem com gestores e dos termos sob os quais elas acessam estas áreas.

Em contraponto, abordagens que compreendem a maior participação de comunidades tradicionais e/ou locais vêm sendo defendida como alternativa para alcançar maior sustentabilidade em APs (OKAZAKI, 2008). Nesse sentido, o turismo de base comunitária $(\mathrm{TBC})$, assunto que será aprofundado na próxima seção devido sua relevância ao presente trabalho, surge como proposta para uma estratégia capaz de repensar a capacidade de suporte dos territórios e suas comunidades, mitigando os impactos negativos do turismo.

\subsection{TURISMO DE BASE COMUNITÁRIA}

O turismo de base comunitária (TBC) se posiciona como iniciativa para a reivindicação do direito ao uso do território, dialogando o desenvolvimento local, a valorização da identidade cultural e a conservação da natureza. Segundo Burgos e 
Mertens (2015), o TBC vêm sendo cada vez mais proposto e adotado principalmente em áreas protegidas, que em sua maioria abrangem comunidades com escassas perspectivas econômicas.

O turismo de base comunitária é aquele no qual as populações locais possuem o controle efetivo sobre o seu desenvolvimento e gestão, e está baseado na gestão comunitária ou familiar das infraestruturas e serviços turísticos, no respeito ao meio ambiente, na valorização da cultura local e na economia solidária (TUCUM, $2008^{17}$ apud SANSOLO, 2009, p. 147).

O seu desenvolvimento, de acordo com Coriolano (2009), está intimamente relacionado à retomada do controle das terras e das atividades econômicas associadas ao turismo ali estabelecidas, por meio de arranjos produtivos locais.

As definições de turismo de base comunitária se apresentam de maneiras diferentes, porém algumas premissas estão presentes em todas elas. A começar, o TBC tem como centralidade o uso dos recursos endógenos, tanto o humano quanto o natural ou de infraestrutura, para o desenvolvimento local.

[...] processo reativador da economia e dinamizador da sociedade local que mediante o aproveitamento dos recursos endógenos que existem em uma determinada zona ou espaço físico é capaz de estimular e fomentar o seu crescimento econômico, criar emprego, renda e riqueza e, sobretudo, melhorar a qualidade de vida e o bem-estar da comunidade local (PEREZ e CARRILLO, $2000^{18}$ apud IRVING, 2009, p. 112).

Segundo Irving (2009), outra premissa deste modelo de turismo é o protagonismo dos comunitários como sujeitos e não objetos do processo, isto é, seu planejamento e desenvolvimento baseia-se nas demandas e cenários internos aos grupos sociais. Duas

\footnotetext{
${ }^{17}$ TUCUM. Rede Cearense de Turismo Comunitário. Presentation held at the II International Seminar on Sustainable Tourism. Fortaleza, 2008.

${ }^{18}$ PEREZ, B.; CARRILLO, E. Desarrollo local: Manual de uso. Madrid: Esic, 2000.
} 
questões são importantes de serem destacadas: em uma visão não romantizada, o TBC se insere na dinâmica do mundo globalizado, porém busca barrar ou reduzir suas imposições, e não há a intenção de uma interpretação estereotipada de comunidades menos favorecidas que recebem turistas interessados em explorar o seu meio sociocultural e natural, mas sim interpreta-se como uma possibilidade de compartilhar experiências e tradições.

Coloca-se igualmente neste processo a essencialidade de se desenvolver o turismo em escala limitada, respeitando as potencialidades e os recursos locais. Divergente a filosofia guiadora dos padrões do turismo de massa, esta proposta associa-se a um comprometimento com a responsabilidade socioambiental. Nesta conexão entre o social e o ambiental que ocupa o primeiro plano, objetiva-se assegurar a participação ativa das populações locais e a qualidade ambiental da área (IRVING, 2009).

A complexidade de se desenvolver um turismo de base comunitária de maneira a assumir caráter longínquo, exige a participação de terceiros para amparar e contribuir na qualificação da comunidade. Nesta questão, evidencia-se o papel fundamental de organizações do terceiro setor. Para Faria (2009), as organizações são essenciais para criar canais de comunicação entre comunidade e Estado, e para controlar as ações estatais no processo. Além disso, a presença de parceiros possibilita um suporte técnico e financeiro para estruturar e operacionalizar o turismo (SANSOLO e BURSZTYN, 2009). Eagles (2009), ao analisar alguns modelos de gestão de uso, observou que as estratégias para a visitação que envolvem organizações do terceiro setor se aproximam mais da noção de boa governança do que as com envolvimento da iniciativa privada, que visam diretamente o lucro.

As articulações horizontais com redes externas a comunidade dá forma ao conceito de capital social de ponte (Figura 8). A ruptura das fronteiras do capital social de ligação são fundamentais para a ampliação do alcance das ações comunitárias (MARTELETO e OLIVEIRA E SILVA, 2004). O desenvolvimento do turismo comunitário consiste em um processo colaborativo e cíclico diretamente ligado à expansão e diversificação de laços externos que dão suporte ao capital social de ponte.

Selin e Chavez (1995) a partir de um "modelo evolutivo de parcerias de turismo" introduz cinco fases desse processo: (i) antecedentes, refere-se a momentos e 
circunstâncias anteriores a formalização de parcerias como crises, mandatos políticos, laços pré-existentes, lideranças, conflitos, entre outros; (ii) definição de problemas, que envolve a identificação do problema comum e relevante entre as partes legítimas, e a construção de consenso; (iii) definição de direção, por meio do estabelecimento de metas e diretrizes básicas para conduzir pesquisas, explorar opções, organizar grupos de trabalho; (iv) estruturar, cuja entendimento inclui formalização de relações e funções, criação de sistemas de controle e monitoramento; (v) resultados, representados por programas e impactos da colaboração.

A análise bidimensional do TBC proposta na Figura 8 sugere um curva baseada no proposto por Butler (1980) norteada por algumas proposições que permeiam seu desenvolvimento.

(1) Quando a participação da comunidade é promovida, a redistribuição de poder será facilitada; (2) sem o avanço do processo colaborativo, a participação comunitária e a redistribuição não ocorrerão; (3) se a participação da comunidade e a redistribuição de poder não evoluir, a colaboração não será estimulada; (4) o desequilíbrio de poder prejudicará a colaboração; e (5) o capital social se estabelece gradualmente e contribui na promoção da sustentabilidade do destino por meio da criação de sinergia tanto dentro da comunidade quanto entre a comunidade e demais atores (OKAZAKI, 2008, p. 517, traduzido pela autora).

A forma exata da curva depende das especificidades dos contextos internos e externos, entretanto Okazaki (2008) observa que tanto no início do processo quanto em estágios mais avançados quando a comunidade já possui mais poder e o capital social é alto há uma lentidão na taxa de mudança, fazendo com que a curva se comporte de maneira semelhante nas partes mais inferiores e superiores.

É possível conjecturar três principais cenários para momentos pós o alcance do estágio de parceria (eixo vertical da Figura 8) por comunidades na promoção turística em APs. Caso haja a concordância (forçada ou não) de outros atores, a curva continuará a subir em direção a maior redistribuição de poder. Outra possibilidade é a estagnação da 
curva se houver uma satisfação com o nível de participação comunitária alcançado ou se outros atores forem contrários a uma nova divisão de poder. O último cenário é o descenso da curva como resultado de uma divisão interna da comunidade ou de uma rejeição a transferência de poder por outras partes interessadas (SELIN e CHAVEZ, 1995).

A idealização e efetivação do TBC como instrumento impulsionador de uma governança compartilhada nasce de uma percepção das próprias comunidades sobre a necessidade de experienciar outra relação com a atividade turística, áreas protegidas e o modo como essas questões repercutem em seus territórios. Nesse sentido, entende-se que a concepção do turismo comunitário reivindica que alguns conceitos e diálogos sejam retomados e evidenciados, considerando a relevância destes no processo, sendo eles:

(a) Território enquanto conceito e processo resultante de modos de apropriação distintos, onde se faz presente construções territoriais ligadas a modos de vida tradicionais e, portanto, reconhece-se o direito de posse e uso de seus recursos;

(b) o caráter relacional de natureza, que ao mesmo tempo que produz é produzida, impossibilitando pensá-la sem sua dimensão social;

(c) a concepção de áreas protegidas a partir de perspectivas patrimoniais e seus desdobramentos frente a sobreposição a territórios tradicionais;

(d) o comum e a possibilidade de gestão comunitária como forma de recuperar o controle efetivo da gestão e manejo dos recursos.

À vista disso, as próximas seções serão desenvolvidas com a finalidade de apresentar e explorar cada um desses pontos, partindo do pressuposto que possuem grande relevância para o alcance de uma compreensão mais ampla do processo de ordenamento e gestão proposto no território de Picinguaba para o uso sustentável da Ilha das Couves, o qual à primeira vista vem sendo pautado pela narrativa do turismo comunitário pautado no fortalecimento comunitário e territorial.

\subsubsection{TERRITÓRIO E CONCEITOS ADJACENTES}

À primeira vista o conceito de território conecta-se diretamente à concepção de terra, superfície terrestre, área ou espaço, vinculando a si a materialidade como principal 
determinante de seu sentido; à segunda, seu conceito assume uma heterogeneidade originária do campo da Geografia, onde há uma intensa e relevante discussão sobre como seu sentido ultrapassa o campo puramente material.

Sob a ótica de Raffestin (1993), a qual assumiremos neste trabalho, espaço e território não possuem teor equivalente. A representação moderna do espaço, segundo o autor, resume-se em três componentes: "a superfície ou o plano, a linha ou a reta e o ponto ou momento do plano". A partir de um espaço, é possível projetar uma abundância de possibilidades, cujas características se moldam de acordo com a apropriação objetiva ou subjetiva de atores que a todo momento realizam associações e dissociações com outros sujeitos ou com singularidades que os interessam.

O movimento de articulação entre a realidade material e as intenções dos atores qualifica o conceito de "territorializar" o espaço. Alicerçado em uma base material, o território origina-se em uma ação de sujeitos dependentes entre si, moldando suas identidades territoriais diversas de acordo com os recursos naturais existentes e manifestando as relações de poder intrínsecas das relações sociais de dominação (RAFFESTIN, 1993).

No processo de construção territorial, ainda de acordo com Raffestin (1993, pp. 148-149), é possível identificar alguns aspectos, que possibilitam entender a característica sistêmica dos territórios, são elas: "toda superfície é passível de ser tecida em malhas; esse sistema de malhas não é único; pode-se estabelecer ao menos um caminho entre dois pontos dessa superfície; esse caminho não é único; entre três pontos dessa superfície, pode-se estabelecer ao menos uma rede ${ }^{19}$ '. A estruturação dessas malhas representam a base de onde se originam as relações hierárquicas e conferem ao território uma diferenciação funcional, de acordo com os tipos de interações entre indivíduos e grupos.

\footnotetext{
${ }^{19}$ Para Raffestin (1993), rede pode ser entendida como um sistema de linhas que interligam pontos dando origem a tramas, e sua natureza vai além do que assegurar a comunicação entre atores. A rede na sua efetivação concreta, tem a capacidade de seccionar um território em limites ou fronteiras, expressando materialmente as hierarquias entre nós, como exemplo das redes rodoviárias. Para mais, sua efetivação também pode ser abstrata, cujos extremos são visíveis porém não os laços que os conectam. Assim, redes garantem um domínio do e no espaço que se formam, fazendo do território produto e meio de produção.
} 
Conforme Holanda (2016), no Brasil a noção sobre território acompanhou a consolidação da ideia de Estado-nação ${ }^{20}$, resultando ainda no século XIX em um processo de afirmação de uma entidade territorial que impôs modos de vivências territoriais e negou sua diversidade sociocultural. A constituição territorial da sociedade ocidental ligase diretamente a relações racionais e burocráticas fundamentadas por convenções formais, documentais e legais. Esse modelo contrapõe-se a um território construído a partir de práticas vinculadas às tradições e afetividades e por integrantes que nem sempre conhecem claramente os limites de seus territórios (MORAES et al., 2017).

A ampliação legal do reconhecimento de territórios constituídos sob outras perspectivas teve como marco a Constituição Federal de 1988, que previa a garantia dos direitos originários sobre terras às populações indígenas, bem como a proteção de costumes, línguas, crenças, tradições e práticas (BRASIL, 1988). À luz da Constituição, em 2007 foi aprovado o decreto 6040, que instituiu a Política Nacional de Desenvolvimento Sustentável dos Povos e Comunidades Tradicionais, a qual compreende a concepção de território tradicional de maneira mais extensa considerando a realidade sociocultural do país, como podemos observar no trecho abaixo:

Territórios Tradicionais: os espaços necessários a reprodução cultural, social e econômica dos povos e comunidades tradicionais, sejam eles utilizados de forma permanente ou temporária [...] (BRASIL, 2007).

Apesar do avanço de instrumentos e legislações em direção à legitimidade de territórios tradicionais, segundo Yamaoka et al. (2019), ainda há uma dificuldade no reconhecimento de terras de determinadas comunidades, como é o caso das populações caiçaras. Este desafio representa uma ameaça direta à existência de outras racionalidades, entendendo que garantir e defender o território é também garantir a vida, a terra comunitária e toda a dimensão sociocultural que ali se estabelece.

\footnotetext{
20 “Em primeiro lugar, a ideologia territorial do Estado-nação é vinculada ao fenômeno do nacionalismo, que reivindica um espaço geográfico para o uso exclusivo dos 'membros' de sua comunidade nacional. Em segundo lugar, essa ideologia territorial fundamenta-se no conceito legal de soberania, que postula a exclusividade do controle de seu território nas mãos do Estado" (LITTLE, 2003, p. 258)
} 
Haesbaert e Limonad, ao realizarem a análise da dimensão material versus simbólica de território, propõe:

O território envolve sempre, ao mesmo tempo [...], uma dimensão simbólica, cultural, através de uma identidade territorial atribuída pelos grupos sociais, como forma de "controle simbólico" sobre o espaço onde vivem (sendo também, portanto, uma forma de apropriação), e uma dimensão mais concreta, de caráter políticodisciplinar: a apropriação e ordenação do espaço como forma de domínio e disciplinarização dos indivíduos (HAESBAERT e LIMONAD, 1999. p. 42).

O controle simbólico do território esboça o conceito de territorialidade, para a qual o autor confere o sentido mais amplo que território, considerando sua íntima ligação com o modo de produção, organização e ressignificação do lugar por quem o ocupa (HAESBAERT, 2007).

Alguns pontos conceituais relativos confundem-se em visões distintas sobre o que de fato diferencia território de territorialidade. De acordo com Haesbaert (2007), comumente a territorialidade é assumida como "aquilo que faz de qualquer território um território", ou seja, se assemelha a ideia de produção territorial. Outra frequente visão, a reduz à dimensão simbólica-cultural, criando uma dualidade entre o que é funcional e o que é simbólico. Neste trabalho, tomaremos seu conceito segundo o designado por Haesbaert (2007) em diálogo com Sack (1986), em que a territorialidade é vista como algo abstrato porém não desconectada do material, considerando que coloca-se como um componente de poder, isto é, constrói-se pelas relações políticas, econômicas e culturais.

Longe de ser algo rígida ou detalhadamente limitada, a territorialidade não se coloca de maneira exclusiva, pelo contrário, com frequência se encontra sobreposta a outras, formando o fenômeno da multiterritorialidade. Antes de prosseguirmos com essa discussão, é essencial que se faça a distinção entre múltiplos territórios e multiterritorialidade. $\mathrm{O}$ primeiro conceito diz respeito à pluralidade de organização/diferenciação que ocupam a superfície terrestre, engendrando relações sociais apoiadas em noções distintas sobre domínio; o segundo, trata-se de uma junção 
de vários sistemas territoriais sobrepostos hierarquicamente a um espaço (HAESBAERT, 2007).

$\mathrm{Na}$ formação da multiterritorialidade há o constante confronto entre formas de territorialidades hegemônicas e demais territorialidades que lutam para permanecer. Little (2003) aponta que apesar de comunidades tradicionais frequentemente ocuparem espaços intersticiais aos grandes centros econômico, sendo marginalizados e invisibilizados, há um movimento por parte de forças econômicas dominantes de expandir a abrangência de sua exploração para estas áreas a fim de se utilizar dos recursos. Nesse cenário, o que se estabelece por diversas vezes é a absorção parcial de influências da economia capitalista pelas comunidades sem que percam totalmente suas particularidades, evitando a hegemonização do território.

Cada sistema territorial imprime sua própria territorialidade, que se exterioriza em todas escalas socioespaciais. Soja (1971), pontua três componentes que juntos constituem a territorialidade: senso de identidade espacial, senso de exclusividade e compartimentação da interação humana no espaço. Sendo assim, a multiterritorialidade se origina no processo de busca de coletivos pelo máximo de autonomia dentro do sistema tridimensional sociedade-espaço-tempo. Dentro destes conjuntos de relações há níveis de estabilidade diferentes, fazendo com que a territorialidade se apresente mais ou menos sensível a mudanças ao passar do tempo (RAFFESTIN, 1993). Conforme Little (2003, p. 265),

Os territórios dos povos tradicionais fundamentam-se em décadas, em alguns casos, séculos de ocupação efetiva. A longa duração dessas ocupações fornece um peso histórico às suas reivindicações territoriais. O fato de que seus territórios ficaram fora do regime formal de propriedade da Colônia, do Império e, até recentemente, da República, não deslegitima suas reivindicações, simplesmente as situa em uma razão histórica e não instrumental, ao mesmo tempo em que mostra sua força histórica e sua persistência cultural. A expressão dessa territorialidade, então, não reside na figura de leis ou títulos, mas se mantém viva nos bastidores da memória coletiva que incorpora 
dimensões simbólicas e identitárias na relação do grupo com sua área, o que dá profundidade e consistência temporal ao território.

Alguns aspectos importantes, segundo Haesbaert (2007), se fazem presente na sintetização desta multiterritorialidade contemporânea, são eles: tecnológicoinformacional, isto é, apropriação via espaço virtual, resultando em uma super valorização da densidade informacional de alguns nós; de redução do tempo e espaço, decorrente da dimensão tecnológica-informacional, que possibilita a supressão dos efeitos da distância espacial; e cultural-simbólico, originado a partir do processo de identificação territorial. Trata-se de um fenômeno diretamente dependente dos níveis de conectividade e instabilidade informacional.

Deleuze e Guattari (1996), na busca por entender a dinâmica territorial no capitalismo, estabelecem um paralelo entre o antes e o pós capital, entendendo que as sociedades pré-capitalistas eram de fato territoriais, pois havia uma relação distinta com a terra. Neste movimento, os autores assumem que as territorialidades mais primitivas possuíam mais flexibilidade devido a ausência de um aparelho de poder centralizador e hegemonizador, o que impedia a segmentação dos seres sociais, técnicos, políticos, artísticos e os seres da natureza. Ao contrário destas sociedades, as territorialidades modernas

possuem uma segmentaridade dura, onde a organização social é sobrecodificada por um aparelho despótico e transcendente do poder, uma máquina despótica que desterritorializa e disciplinariza os corpos (HAESBAERT e BRUCE, 2002, p. 18).

Esta desterritorialização, ainda segundo Deleuze e Guattari (1996), se posiciona como uma constante dinâmica no capitalismo; mais além, a desterritorialização vem intrinsecamente acompanhada da reterritorialização. A ênfase destes processos se fundamenta na mobilidade progressiva das territorialidades modernas, rompendo com a rigidez que antes se fazia presente. Assim, a des-reterritorialização se materializa na destruição e reestruturação do território e, consequentemente, na exclusão territorial (HAESBAERT, 2003). 
A revisão histórica do litoral norte de São Paulo e de Picinguaba permite o entendimento de como se deu o processo de des-reterritorialização a partir do avanço capitalista principalmente vinculado à prática turística. A modificação material e simbólica que o território vem vivenciando reflete em uma exclusão igualmente material e simbólica, seja na perda concreta de espaços ou na supressão de significados e relações socioculturais.

Há uma linha tênue entre os limites da multiterritorialidade e da desreterritorialização, e a todo momento estes fenômenos se confundem. Enquanto para a classe social mais alta apoderar-se de outros territórios é apenas colocar em prática o seu livre arbítrio de ir e vir, garantindo-se de uma multiterritorialidade segura, para determinados grupos sociais, este processo se impõe como uma multiterritorialidade insegura, isto é, uma desterritorialização, considerando que por inúmeras vezes o resultado é a mobilidade obrigatória e a consequente privação do “pertencer”(HAESBAERT, 2003). Há aqui os atores hegemônicos, que garantem o acesso aos recursos e os hegemonizados, que procuram constantemente os alvéolos espaciais para sua sobrevivência.

É possível pensar que ambos fenômenos estão diretamente ligado à um espaço social demasiadamente heterogêneo, onde se instala um implexo de "geometrias de poder". Segundo as palavras de Haesbaert,

A multiterritorialidade é, se não a forma dominante, pelo menos a forma contemporânea ou "pós-moderna" da reterritorialização [...]. Ela é consequência direta da predominância dos territóriosrede, sobrepostos e descontínuos, sobre os territórios-zona, exclusivistas e contínuos, que marcaram aquilo que se pode denominar de modernidade clássica, dominada pela lógica territorial exclusivista de padrão estatal (HAESBAERT, 2005, p. 19).

O processo de desterritorialização de comunidades tradicionais nem sempre se mostra por meio de uma violência explícita. De acordo com Calvente (2016), há contextos em que mesmo estas comunidades estando territorializadas no seu sentido concreto, ela sofrem a desterritorialização em sua dimensão simbólica-cultural. Esse processo, apesar 
de muitas vezes assumir qualidades sutis, contribui para impossibilitar de forma gradual que determinados grupos construam e exerçam o controle factual de seus territórios. A autora, ao estudar os efeitos do turismo no território caiçara da praia do Curral em Ilhabela/SP, relata como exemplo desse processo:

A instalação do turismo na ilha, promovendo o desenvolvimento do comércio, do setor de prestação de serviços, do rearranjo e/ou da criação de novas formas e novas funções para atender à demanda estrutural da atividade turística, acabou por diminuir a importância do mar, da floresta e da horta no quintal para a subsistência da comunidade caiçara.

A necessidade de mão de obra e o seu consequente assalariamento permitiram uma diminuição efetiva da importância material e simbólica dos quintais das famílias caiçaras [...] (CALVENTE, 2016, p. 45).

As abstrações acerca das diferentes formas de apropriação do território demonstram a divergências de noções em relação a apropriação dos recursos territoriais. A partir disso, é plausível refletir com maior propriedade sobre a relação sociedadenatureza, cuja raiz concretizou-se no domínio e usufruto do meio ambiente como recurso. Considerando o território como produto histórico, entende-se como necessário retomar o diálogo entre natureza e comunidades tradicionais sob uma abordagem histórica para que seja possível analisar o que está sendo defendido e reafirmado no processo de gestão comunitária do turismo.

\subsubsection{A RELAÇÃO ENTRE NATUREZA E COMUNIDADES TRADICIONAIS}

A propriedade material e imaterial do território e fenômenos correspondentes passam necessariamente pelo reconhecimento da unidade entre dimensões da economiapolítica-cultura-natureza. Conforme Marcos Aurelio Saquet,

O espaço é uma realidade relacional, envolvendo a natureza e a sociedade mediadas pelo trabalho (energia), técnicas, tecnologias

e, evidentemente, pelo conhecimento. O gastar energia, no 
trabalho, é o grande mediador da relação sociedade-natureza, na qual há objetos naturais e objetos sociais em movimento permanente, heterogeneidade do espaço habitado, expansão da população, urbanização, hierarquias, fixos e fluxos. O espaço é produzido pelas ações dos homens sobre o próprio espaço, que aparece como paisagem artificial. O trabalho e as técnicas ganham centralidade em sua argumentação; o homem é o sujeito, as técnicas, a mediação e o espaço é um produto histórico (SAQUET, 2009, p. 77).

Casseti (1991), ao dialogar com a perspectiva marxista sobre natureza, aborda a ideia de uma "primeira natureza" precursora a existência humana, desenhada apenas por suas propriedades geoecológicas. Dada a evolução humana, datada pela época do pleistoceno, e consequentemente o avanço nos modos de apropriação e transformação dessa natureza antecedente, há o desenvolvimento de um segundo estágio, cujas características passam a depender também das diferentes formas de manejo dos recursos determinadas por leis transitórias da sociedade. Desse modo, assume-se que a história da humanidade é o desencadeamento da história da natureza.

Trata-se, portanto, de um processo de produção da natureza, onde a natureza e o homem se integram e interagem. Esse processo de apropriação e transformação da natureza pelo homem, coloca em movimento braços e pernas, cabeças e mãos, em ordem para apropriar a produção da natureza numa forma adaptada às suas próprias necessidades. Por assim agir no mundo externo e mudando-o, ele ao mesmo tempo muda sua própria natureza (CASSETI, 1991, p. 12).

No sistema econômico atual vigente esta organização espacial e, consequentemente, a produção territorial, determina-se por fatores impostos pelo capital. O território se produz de maneira hegemônica subordinado a diretrizes que assimilam o espaço/natureza sob viés levianamente utilitarista. A sociedade moderna é marcada desde seus primórdios pela quebra do complexo metabólico homem-natureza, o que definiu um decurso que se inicia numa apropriação alienada da natureza, passa por uma reprodução 
ampliada do espaço, onde a des-reterritorialização tem um conveniente papel, e resulta em uma subordinação de cerne classista (CAMACHO, 2010).

Em contraponto ao processo territorial dominante se faz presente, mesmo que a muito custo, outras territorialidades originadas em uma relação simbiótica entre o homem e a natureza, nas quais a vida cotidiana constitui-se por mediações primárias. O caráter pré-capitalista das populações tradicionais expressa-se tanto no campo da técnica e da prática quanto no simbólico, envolvendo uma concepção mítica que influencia diretamente nas atividades de subsistência e culturais. O uso dos recursos pertence a um lugar de evidência, a medida que determina a ocupação de um território de acordo com seus ecossistemas (PEREIRA e DIEGUES, 2010; TIRIBA e FISCHER, 2015).

[...] tanto os indivíduos da espécie humana como as entrelaçadas condições culturais/intelectuais/morais/materiais cada vez mais complexas de sua vida são reproduzidos segundo a margem de ação sócio-histórica disponível e cumulativamente ampliada. Entre essas condições estão: a regulação da atividade reprodutora biológica, mais ou menos espontânea e imprescindível, e o tamanho da população sustentável, em conjunto com os recursos disponíveis; a regulação do processo de trabalho, pelo qual o indispensável intercâmbio da comunidade com a natureza produz os bens necessários para gratificação do ser humano (MÉSZÁROS ${ }^{21}$, 2006, p. 213 apud TIRIBA e FISCHER, 2015, p. 417).

Antes de prosseguirmos com esta discussão, uma breve revisão conceitual a respeito de comunidades tradicionais será apresentada. No Brasil, estas comunidades são definidas pelo decreto $\mathrm{n}^{\circ} 6.040 / 2007$, como:

[...] grupos culturalmente diferenciados e que se reconhecem como tais, que possuem formas próprias de organização social, que ocupam e usam territórios e recursos naturais como condição

${ }^{21}$ MÉSZÁROS, István. Para além do Capital. São Paulo: Boitempo, 2006. 
para sua reprodução cultural, social, religiosa, ancestral e econômica, utilizando conhecimentos, inovações e práticas gerados e transmitidos pela tradição (BRASIL, 2007, art. 3, inciso I).

A adoção do termo "populações tradicionais"'22 expressa uma abrangência característica da diversidade de grupos que se identificam como tradicionais. De acordo com a história ou memória do espaço em que vivem, essas populações se afirmam com pelo menos uma das seguintes categorias: a) são sucessores de povos ancestrais, cuja existência vem de tempos longínquos e certas informações estão totalmente apagadas dos registros históricos, restando apenas na memória; b) são herdeiros de povos ancestrais reconhecidos, de quem há maiores volumes de dados, possibilitando resgatar a linha de sucessão até o presente; c) a geração de mais velhos, porém ainda vivos, se reconhece como fundadora do território e da comunidade em que vivem; d) um grupo se apropria de algum espaço e constitui ali uma comunidade com identificação cultural similar a comunidades mais antigas, ou seja, altera-se o lugar, mas não o modo de vida (BRANDÃO e LEAL, 2012; BRANDÃO e BORGES, 2014).

Há algumas convergências entre os modos de vida dessas comunidades e os modos de produção anteriores ao capitalismo, em que o trabalho não era tido como mercadoria e o manejo dos recursos naturais destinava-se a reprodução social e cultural e não ao lucro. Segundo Tiriba e Fischer (2015), destaca-se também a característica familiar, comunitária e coletiva de suas práticas e o domínio completo do processo produtivo. A conexão entre as populações tradicionais e a natureza reflete em uma noção de território que é caracterizada por direitos concretos de acesso, controle e usufruto do espaço natural que alicerçou a constituição de suas sociedades (DIEGUES, 2008).

A ocupação e controle do território por diferentes populações assume características distintas. Algumas reproduzem seu meio de vida se utilizando de uma

\footnotetext{
${ }^{22}$ Há um certo incomôdo no uso do termo "populações tradicionais", devido ao fato de que muitos grupos étnicos não se autoidentificam dentro desta generalização (PEREIRA e DIEGUES , 2010). Devido ao caráter denso desta discussão, na qual faz-se necessário o aprofundamento nas diferentes vertentes antropológicas, seguiremos empregando populações ou comunidades tradicionais, apenas pela seu sentido abrangente.
} 
pluralidade de ecossistemas, o que demanda um profundo conhecimento para sincronizar a exploração com os ciclos naturais. O caso das comunidades caiçaras do litoral de São Paulo, por exemplo, mostra a estreita relação entre a floresta e o ambiente marinho, na qual a Mata Atlântica fornece a matéria-prima para a reprodução de seu modo de vida, como exemplo a construção de canoas e equipamentos de pesca. A associação da subsistência com o mar faz com que as proporções do território sejam mais amplas se comparadas a comunidades que se utilizam apenas da terra (DIEGUES, 2008).

Para além do respeito aos ciclos da natureza, há o estabelecimento de um vínculo que extrapola a esfera material, envolvendo representações e mitos. Contudo, esta conexão não pode ser vista superficialmente, pois há uma certa racionalidade composta por abstrações e conhecimento "científico", fruto da íntima interação e dependência do homem com seu meio. Este imaginário mítico influencia diretamente na dinâmica de manejo dos recursos (ARRUDA, 1999; PEREIRA e DIEGUES, 2010). De acordo com Lévi-Strauss (2008), a interpretação dos mitos e ritos passa necessariamente por uma perspectiva estrutural, na qual a identificação de plantas e animais que são citados e/ou utilizados é obrigatória.

De acordo com Diegues (2008), algumas comunidades deixam de explorar certas áreas por as considerarem sagradas e consequentemente, impróprias para atividades econômicas. $\mathrm{O}$ autor traz o exemplo dos pescadores Tofinu, habitantes do país africano Benim, que não pescavam em determinados lugares da lagoa Nokoné, pois eram local de descanso de uma deusa de sua cultura. Após pesquisas, foi observado que esse costume contribuia para a manutenção do recurso pesqueiro, já que eram áreas de reprodução. Outro exemplo desta relação mítica, é o uso da Artemísia (gênero Artemisia) por comunidades primitivas da América do Norte. Pesquisas posteriores demonstraram que essa planta, que possuía conotação feminina e era utilizada em rituais por mulheres, era proveitosa no tratamento de quadros relacionados a menstruação (LÉVI-STRAUSS, 2008).

Diferente dos modelos de território urbano-industriais característicos das sociedades modernas, os espaços apropriados por populações tradicionais apresentam certos níveis de descontinuidade. Sejam por questões míticas, como citado no parágrafo anterior, ou por questões materiais, algumas áreas são marcadas por um vazio aparente, 
isto é, são deliberadamente inutilizadas. Terras cultiváveis que encontram-se em repouso, zonas estuarinas que são utilizadas para pesca apenas em estações específicas do ano ou ainda, florestas e rios que são considerados sagrados e por isso não são explorados, são diversas vezes tomados como espaços “de ninguém” por sujeitos externos àquela realidade (DIEGUES, 2008).

Antes de darmos continuidade à discussão, é necessário explicitar que as abstrações acerca da relação entre comunidades e meio ambiente se dão frequentemente de maneira romantizada. O objetivo deste trabalho não é cair na idealização do "mito do ecologicamente bom selvagem", onde há uma visão que esta relação é harmoniosa ao ponto de não haver impactos ambientais resultantes. O manejo dos recursos naturais por estas populações, apesar de ser realizado de forma menos intensa, não está intrinsecamente ligado a uma ideologia conservacionista, sendo apenas efeito de uma coexistência consciente.

O modo específico de reprodução sociocultural de cada uma dessas comunidades e a ocupação descontínua de seus territórios contribuiu para o avanço de uma cultura mundial hegemônica interferindo diretamente em suas territorialidades. Além das invasões das práticas de exploração capitalista, houve também a imposição de regras conservacionistas por autoridades ambientais, o que resultou em um cenário onde homem e natureza já não podiam se relacionar da maneira como o faziam historicamente, restringindo bruscamente as atividades tradicionais (PEREIRA e DIEGUES, 2010).

A inserção, mesmo que forçada, de populações tradicionais ao modo de vida capitalista coloca uma questão importante, é incoerente pensá-las de modo inerte ou fixo e desconsiderar sua mudança processual. A difusão do capitalismo atingiu em diferentes graus as culturas locais e regionais, ao mesmo tempo que houve o aniquilamento de inúmeras culturas, diversas comunidades assimilaram determinados padrões hegemônicos. Diegues (2008) denominou esta fusão como "pequena produção mercantil”, o que não representou uma transformação radical, mas sim a criação de uma dependência parcial do mercado.

Moreira Pinto (2007) ao analisar os impactos da interferência capitalista com um recorte à atividade turística nas relações e práticas de comunidades tradicionais aponta que há um abandono ou um enfraquecimento de técnicas produtivas tradicionais ligadas 
aos seus modos de vida. Ao se alterar a forma relacional entre as ordens sociais e naturais, altera-se também os padrões culturais que vão desde crenças e misticismos à maneiras como são estabelecidas conexões interpessoais.

No contexto da mundialização do capital, não há como desconsiderar que, nessas comunidades, as mediações de primeira ordem estão fortemente atravessadas por mediações de segunda ordem do capital. As bases materiais e simbólicas, econômicoculturais que fundamentam e dão sustentação à vida na comunidade (mediações de primeira ordem), são constantemente ameaçadas pela racionalidade destrutiva da sociedade produtora de mercadorias, ou seja, da sociedade capitalista (TIRIBA e FISCHER, 2015, p. 413).

Ao mesmo tempo em que lidam e vivenciam os efeitos do avanço capitalista, notase que os povos tradicionais passam a dar atenção a questões sociopolíticas como forma de conservar pelo menos uma parte de práticas e tradições que vêm permanecendo em diferentes momentos históricos.

O que este cenário deixa de reconhecer é que a situação mudou, e com ela a validade dos antigos paradigmas. As populações tradicionais não estão mais fora da economia central, nem mais simplesmente na periferia do sistema mundial. As populações tradicionais e suas organizações não tratam apenas com fazendeiros, madeireiros, garimpeiros. Elas tornaram-se parceiras de instituições centrais como as Nações Unidas, o Banco Mundial e as poderosas ONGs do "primeiro mundo" (CUNHA, 2009, p. 16).

Conforme aponta Brandão e Borges (2014), as comunidades "se fazem ouvir em um triplo sentido": a) se organizam para afirmar seus direitos e cobrar do Estado e ONGs comprometimento, em defesa de seus territórios patrimoniais, mas igualmente de seus "patrimônios culturais imateriais"; b) se colocam no mercado muitas vezes de forma inovadora e proveitosa financeiramente, utilizando-se principalmente de produtos 
coletados da natureza; c) ressignificam-se como agentes ativos na conservação do meio ambiente anteriores às políticas públicas ambientais.

Ainda assim, há um quadro intenso de conflitos entre comunidades e atores das diferentes atividades econômicas que assolam os recursos naturais, como fazendeiros, madeireiros, mineradores, agentes turísticos, entre outros, o que as coloca em constante posição de empobrecimento, marginalização ou desalojamento.

O silenciamento de modos de vida tradicionais, como discutido nessa seção, conecta-se diretamente a expansão de práticas capitalistas. Do mesmo modo, observa-se que esse processo também diz respeito ao avanço de noções preservacionistas materializadas principalmente por meio da criação de áreas protegidas - que contribuíram com uma nova inflexão relacionada a uma criminalização ou contenção de determinadas atividades constituintes da cultura desses povos.

\subsection{3. ÁREAS NATURAIS PROTEGIDAS E A QUESTÃO TERRITORIAL}

Se retomarmos de maneira mais extensa os primórdios da concepção de áreas protegidas como instrumento de conservação ambiental é possível retroceder para o século quarto antes de Cristo, no qual atividades extrativistas já eram proibidas em certas florestas consideradas sagradas. Há também notícias de instrumentos similares em 240 a.C. na região da Índia ou entre 700 e 350 anos a.C. nas regiões ocupadas por assírios e persas. Nota-se que de maneira geral essas experiências estavam profundamente ligadas a práticas religiosas ou especificamente à caça (LEUZINGER, 2007).

Contudo, realizando o recorte do tema a evolução da sociedade ocidental, compreende-se que a origem desse modelo para a conservação remete ao Estados Unidos do século XIX, mais precisamente ao ano de 1872 com a instituição do Parque Nacional de Yellowstone, o qual recebe o título de primeiro parque nacional da história. Sob a lógica da patrimonialização, criou-se a imagem de um mecanismo de proteção de responsabilidade da União e dos Estados e cuja abordagem assume características topdown, justificada por valores estéticos, ecológicos e científicos, e ignorando a amplitude 
que um território pode ter (SOLIKU e SCHRAML, 2018; ZANIRATO e RIBEIRO, 2006).

O surgimento das áreas protegidas acompanhou o crescimento de um movimento preservacionista, cuja maturação se deu no século XIX principalmente na Grã-Bretanha e Estados Unidos. Alinhado à ideia de wilderness (natureza em seu estado selvagem), o preservacionismo delineava-se a partir da crença de um possibilidade de se preservar parcelas naturais “virgens". Little (2003) qualifica esse movimento de "preservacionismo territorializante" considerando que o controle integral e único sobre grandes espaços geográficos assume um papel central em ações pautadas por ele. Uma das maiores expressões dessa lógica no Brasil foi a criação e ampla utilização de áreas protegidas que prevêem apenas o uso indireto do território.

Como as Unidades de Conservação de Uso Indireto não permitem a presença de populações humanas dentro de seus territórios [...], a solução inicialmente proposta pelos preservacionistas foi a expulsão dos habitantes de "seus" novos territórios, seja por indenização ou por reassentamento compulsório, tal como se fazia com as barragens e os outros grandes projetos de desenvolvimento. $\mathrm{Na}$ linguagem dos preservacionistas, esses habitantes viraram "populações residentes", categorizando-lhes assim em função das novas áreas protegidas e, no processo, ignorando a existência prévia de regimes de propriedade comum, relações afetivas com o seu lugar e memórias coletivas sobre esses mesmos espaços (CULTURAL SURVIVAL QUARTERLY, $1985^{23}$ apud LITTLE, 2003, p. 273).

A importação desses modelos de proteção ambiental ao Terceiro Mundo ${ }^{24}$ engendrou conflitos territoriais que se estendem até os dias atuais. A presença de diversas

\footnotetext{
${ }^{23}$ CULTURAL SURVIVAL QUARTERLY. Parks and people, v. 9, n. 1, 1985.

${ }^{24}$ O conceito "Terceiro Mundo" se perpetuou no pós segunda guerra mundial, quando os Estados Unidos engendraram uma campanha política de escala global lançando um novo conceito sobre desenvolvimento e um chamado para que os países seguissem seus passos. Utilizando-se do termo "subdesenvolvido", criouse uma dicotomia entre modelos sociais e econômicos que eram ou não desejáveis. A partir desse momento
} 
comunidades tradicionais habitando as florestas e também as costas contribuía para compor uma situação ecológica, social e cultural com maior grau de complexidade. As medidas de implantação de áreas protegidas representaram um choque entre mitos, considerando que estas populações tinham suas próprias relações e representações mitológicas da natureza (DIEGUES, 2008).

O avanço do movimento preservacionista com a instituição de inúmeras APs se deu principalmente no período do pós-segunda guerra mundial, décadas marcadas pela "era do desenvolvimento". A ascensão mútua entre exploração econômica e preservacionismo compôs um duplo movimento de des-reterritorialização de territórios tradicionais. O primeiro, cujo objetivo era único e exclusivamente aquecer o sistema econômico vigente, compreendia a natureza apenas como recurso ${ }^{25}$ do qual se utilizavam para produção mercadológica (SOUZA-LIMA, 2006). O outro, em partes estimulado pela tentativa de frear esta exploração, encabeçou o que Diegues (2008) veio a chamar de "o mito $^{26}$ da natureza intocada", em que a natureza passou a ser vista como passível de patrimonialização como objeto que não foi e não pode ser tocado.

Antecedendo e fundamentando a lógica da patrimonialização, sob o aspecto etimológico, a concepção de patrimônio deriva da ideia de "herança paterna", fazendo

dois terços da população mundial com toda sua heterogeneidade, medida pela "régua do desenvolvimento", passou a ser considerada subdesenvolvida (ESTEVA,1992).

25“Recurso" abriga a ideia de demanda, isto é, um elemento da natureza não é essencialmente recurso e sim tornar-se um. Este processo, para se concretizar, obriga que tal aspecto esteja em uso ou que ao menos seja necessitado. Em um determinado momento histórico, certo aspecto pode se converter em recurso e deixar de sê-lo em outro, dependendo diretamente dos níveis tecnológicos alcançados ou valores culturais de uma sociedade em algum tempo e espaço. Seu uso sempre ocasionará transformação em diversas escalas e intensidades, podendo ser mínimas se a dinâmica natural e os aspectos éticos forem considerados (VENTURI, 2006).

A apropriação da natureza transformando-a em um recurso se dá a partir de diferentes maneiras e porquês. Abrange os usos diretos e indiretos e pode se dar por sobrevivência ou por satisfação oriunda de um conjunto de valores culturais absorvidos por determinada sociedade (VENTURI, 2006). Nas relações de poder, conforme Raffestin (1993), o acesso a um recurso ou o domínio de uma população à ele são as raízes das disputas territoriais.

${ }^{26}$ Esta compreensão foi equiparada ao pensamento mítico e simbólico de sociedades pré-capitalistas. A modernidade, ultrapassando as antigas mitologias, dá luz a outras de forma contemporânea. "O neomito reintroduz a explicação pelo vivo, o singular, o concreto onde reina a explicação pelo físico, o geral, o abstrato. Mas é o concreto vivido que, infiltrando-se na ideia abstrata ou geral, a torna viva. Não reintroduz os deuses e os espíritos. Espiritualiza a ideia a partir do interior. Não retira necessariamente o sentido racional da ideia parasitada. Inocula-lhe uma sobrecarga de sentido, que a transfigura. Assim, as mitologiasnarrativas do tipo antigo dissipam-se, mas as ideologias recolhem e alimentam o núcleo do mito; é assim que se pode perguntar se o nosso século está realmente menos mitificado que os tempos mitológicos" (MORIN, 1996, p. 157). 
referência a "propriedade herdada do pai ou de antepassados" ou "aos monumentos herdados das gerações anteriores", relacionando à memória e aos sentimentos (PELEGRINI, 2006).

[...] esta ideia de patrimônio expressa, dentro dos limites da esfera familiar, relações de um conflito social em que há correlações de força entre sujeitos em determinado momento e lugar, cujas condições de poder de cada um se estabelecem a partir da apropriação de bens ou coisas. À vista desta lógica, o patrimonial só se constitui a partir da apropriação, sendo ao mesmo tempo reflexo e produtor de uma relação social histórica na qual sujeitos (re)produzem, consomem e transferem propriedades (CIOFFI e RAIMUNDO, 2020, não paginado).

A introdução desse conceito ao âmbito social deu origem a uma lógica que de certa forma moldou diferentes processos de ativação patrimonial, os quais inicialmente voltaram-se à dimensão cultural e posteriormente ocuparam também a dimensão ambiental. Perez (2003) aponta que a instituição de patrimônios se mostrou por vezes hierárquico e intimamente relacionado aos gostos da elite.

Segundo Zanirato e Ribeiro (2006), a criação de patrimônios naturais se desenhava majoritariamente a partir de três critérios: o valor estético, expresso nas paisagem de grande beleza natural ou com alguma exceção, o valor ecológico, relacionado à conservação da biodiversidade e o valor científico, manifestado em locais com formações ou fenômenos naturais importantes para o conhecimento da história natural. Fazendo coro ao preservacionismo, a patrimonialização de parcelas naturais trouxe consigo o objetivo de destiná-las a pura contemplação, posicionando e limitando o sujeito a um lugar de espectador (CHAUI, 2003).

A crença da existência de espaços naturais "puros" e a possibilidade de patrimonializá-los por meio da criação de áreas protegidas foi fortalecida na ascensão da racionalidade, que negou conhecimentos históricos, antropológicos, culturais e ambientais, nos quais era apontado que a natureza é também uma criação da humanidade. As diversas biodiversidades mundiais seriam um produto histórico fruto da intensa interação entre homem e natureza, isto é, o que regularmente é tido como padrão natural 
é senão o resultado de padrões de uso e ocupação da terra e seus recursos. À vista disso, a criação do "mundo selvagem inalterado" dependeu da dizimação de populações e suas territorialidades, que antes tinham estas áreas como seu lar (BENSUSAN, 2006).

A instituição de uma perspectiva dicotômica entre "povos" e "áreas protegidas" passa obrigatoriamente por um entendimento rudimentar sobre território. É importante pontuar que a intervenção estatal para delimitação destas áreas não desterritorializou apenas comunidades tradicionais, mas também grupos sociais que já haviam territorializado alguns daqueles espaços. Conforme apontado por Vallejo (2002) sobre o movimento de fortalecimento deste modelo de preservação,

[...] a dimensão biológica do território assume um papel relevante, mas isso só se consolidaria na medida em que os governos e a sociedade se conscientizassem sobre a questão. A criação legal de parques e reservas não é garantia de cumprimento de seu papel, mesmo que ele esteja restrito apenas à preservação de belezas naturais ou santuários da vida silvestre.

Do mesmo modo, Diegues (2008) expõe que a expulsão de populações contribuiu para reduzir a eficácia deste modelo, levando em consideração que a falta de presença de pessoas nas áreas possibilitou o avanço de atividades extrativistas pela iniciativa privada, além de obrigar que os antigos moradores extraíssem ilegalmente recursos importantes para sua subsistência.

Há que se reconhecer que ao longo da história houve a necessidade de estabelecer o controle do homem sobre o próprio homem. Apesar das contradições, a delimitação de APs contribuiu de fato para conter parte do avanço de práticas exploratórias capitalistas sobre os recursos naturais de determinados territórios (VALLEJO, 2002). Entretanto, contraditoriamente, diversas áreas foram cooptadas pelo capitalismo. Segundo Cioffi e Raimundo (2020, não paginado), "no embate entre a preservação e o avanço de áreas com potencialidades econômicas, restavam aos parques os locais sem valor comercial".

A expansão do setor turístico coloca um novo e específico cenário de desreterritorialização. Envolvendo os interesses da esfera privada, a narrativa que se constrói é a desterritorialização física ou simbólica de populações tradicionais e a 
reterritorialização do espaço com a chegada de atores ligados ao turismo e veraneio, resultando na implantação de facilidades turísticas para o oferecimento destas áreas ao usufruto do visitante. Deste modo, duas tendências são reforçadas e nenhuma delas diz respeito a melhorar a situação da vida das comunidades tradicionais: uma se resume na necessidade de proteção dos ecossistemas e processos essenciais; a outra contempla o interesse do setor turístico (VALLEJO, 2013; DIEGUES, 2008).

Este processo começou a ser repensado em meados da década de 1970, com a evolução da significação e objetivos das áreas protegidas, muito devido à mobilização de algumas comunidades e ao acontecimento de grandes encontros internacionais sobre o tema. Houve um esforço no sentido de barrar a expulsão das populações e envolvê-las em espaços de planejamento e gestão das unidades. Contudo, ainda por um longo período esse envolvimento se deu de forma superficial, no intuito apenas de minimizar conflitos ou estimular uma desterritorialização “voluntária” (DIEGUES, 2008).

O ponto de partida e os rumos que a evolução das áreas protegidas assumiu despontou em uma realidade hostil que demanda esforços maiores do que o Estado pode promover, demonstrando que este modelo de proteção e regulação encontra-se em crise (RAIMUNDO, 2008). À vista disso, chama-se a atenção ao crescimento desde os anos de 1980 de um outro movimento ambientalista ligado a perspectivas socioambientais, que contrapõe o preservacionismo e traz em si a maior participação política da sociedade civil como centralidade.

De acordo com Little (2003), alinhado a consolidação do conceito de desenvolvimento sustentável - cujo ideal envolve a correlação da tríade economiasociedade-meio ambiente - o socioambientalismo vêm contribuindo para desenhar e implementar modelos de cogestão territorial, nos quais órgãos ambientais e determinados grupos sociais atuam em conjunto para gestão, manejo e fiscalização de áreas protegidas.

Ao canalizar as múltiplas formas de construção territorial, de apropriação da natureza e a possibilidade de se pensar em modos descentralizados de gestão e uso, a discussão acerca da propriedade coletiva de bens comuns representa peça fundamental na luta pela garantia de outras formas de exploração dos recursos naturais que fogem da lógica hegemônica da propriedade privada, ou mesmo do controle estatal. 


\subsubsection{O COMUM E A GESTÃO COMUNITÁRIA}

No Brasil, a discussão sobre o comum tem sido aplicada de maneira expressiva por pesquisadores no campo do meio ambiente e relacionados aos direitos das comunidades tradicionais. Na história política-cultural anglo-saxã, commons eram terras comunais partilhadas entre todos, que foram gradualmente se extinguindo à medida que o processo de organização da propriedade privada avançava. Em português, por não haver termos semânticos, há quem opte por empregar "bem comum" ou apenas "comum"27 (SILVEIRA e SAVAZONI, 2018). Neste trabalho entendemos que os dois conceitos podem ser lidos como sinônimos.

Ao ser introduzido a essa discussão, o conceito de comum passa paradoxalmente a ser visto como algo que não pertence a ninguém ou que pertence a todos, a depender da perspectiva de análise. Garrett Hardin, um dos precursores do tema, fia-se na ideia do homem autointeressado, cujo foco se resume a aumentar seus ganhos, incapacitando-o assim de cooperar com seus semelhantes para evitar a superexploração de determinado bem. Utilizando-se da imagem do rebanho de ovelhas como exemplo, aponta:

Cada homem está preso em um sistema que o compele a aumentar seu rebanho sem limites - num mundo que é limitado. Ruína é o destino para o qual todos os homens caminham, cada um perseguindo seu próprio interesse em uma sociedade que acredita em bens comuns livres. Comuns livres trazem ruína para todos (HARDIN, $1968^{28}$ apud SILVEIRA e SAVAZONI, 2018, p. 8).

A partir de sua teoria, Hardin coloca então que o problema ambiental é consequência de dois fatores: o crescimento populacional, que aumentará proporcionalmente o uso dos recursos, e a forma de organização humana para extração

\footnotetext{
${ }^{27}$ Para Dardot e Laval (2017) há uma diferenciação entre comuns, no plural, e comum, no singular. O termo "comum", no singular, é entendido como uma proposta que busca novas formas de desenvolvimento e de relacionamentos da sociedade com o meio. Um movimento que emerge no desencanto com o Estado e com a empresa capitalista. O comum é entendido, assim, como algo universal e não vulgar ou corriqueiro. E, uma vez identificado esse interesse coletivo, o grupo o defende ou o reivindica por meio de uma ação política coletiva. O comum é algo de interesse coletivo e esse coletivo oferece uma resistência ou ação para mantê-lo como tal, afastando-o de um entendimento individualizado, ou de mercado.

${ }^{28}$ HARDIN, Garrett. The tragedy of the commons. Science,v. 162, n. 3.859, p. 1.243-1.248, 1968.
} 
destes. Deste modo, o autor defende apenas dois modelos de organização possíveis, os quais baseiam-se na forte regulação estatal ou na privatização. A centralização pelo Estado se resumiria principalmente na imposição de sanções econômicas de forma a tornar a exploração mais custosa. Já a privatização, apesar de apresentar algumas contrariedades, poderia frear o uso excessivo pelo coletivo devido ao poder de regulação do proprietário (SIMÕES et al., 2011).

Sob outro prisma, Elinor Ostrom se posiciona na discussão a partir de um esforço em analisar a auto-organização de diversas comunidades na gestão sustentável de seus recursos. A autora parte de uma visão menos egoísta do ser humano, enxergando-os "como criaturas adaptativas que tentam prosperar". Seus estudos demonstraram que ao decorrer do tempos comunidades sem aprofundamento técnico estabeleceram intuitivamente gestões democráticas, com altos níveis de participação e cooperação (SIMÕES et al., 2011; SILVEIRA e SAVAZONI, 2018). No cerne desta colaboração mútua está a confiança e capacidade de diálogo. Assim, observa Bollier,

Um comum necessita que haja uma comunidade disposta a atuar como guardiã rigorosa do recurso em concreto. E Hardin confunde um terreno comunal com a "terra de ninguém", desacreditando assim os comuns como um paradigma frustrado de gestão dos recursos (BOLLIER, 2016, p. 31).

Mckean e Ostrom (2001) aponta que no ensaio de Hardin (1968) sobre a tragédia dos comuns o autor ignora em partes a diferença entre o compartilhamento do uso de um comum e a ausência de direitos de propriedade e ou de regime de manejo, o que na opinião das autoras é onde se encontra o problema. Sobre isso, elas explicitam que o termo "base comum de recursos" 29 está ligado às qualidades físicas de sistemas de recursos, já "propriedade comum" ou "regime de propriedade comum" dizem respeito a modelos de arranjos nos quais grupos dividem os direitos de propriedade e responsabilidades sobre o recurso.

\footnotetext{
${ }^{29}$ Tradução do termo em inglês common pool resources.
} 
Feeny et al. (2001 apud RODRIGUES, 2009) apresenta algumas divisões básicas dentro da possibilidade de arranjos e direitos de propriedade, ressaltando que podem ocorrer sobreposições ou choques entre elas. Os autores propõem as seguintes divisões: (a) livre acesso aos recursos e ausência de direitos de propriedades, pelo menos de forma bem definida e clara; (b) propriedade privada dos direitos de exploração, na qual o indivíduo ou grupo detém exclusividade e liberdade para passar os recursos da forma que quiserem; (c) propriedade comunal dos recursos, onde o manejo é realizado por um grupo de pessoas interdependentes; e (d) propriedade estatal dos recursos, onde o Estado estabelece regras de uso e por diversas vezes as coloca coercitivamente.

Regimes de propriedade comum são formas de privatizar direitos sobre um objeto sem dividi-lo em pedaços; oferecem uma maneira de parcelar o fluxo de "rendas" da colheita (o lucro) de um sistema integrado de recursos sem que haja parcelamento do capital em si. Tais regimes seriam obviamente desejáveis em situações onde o manejo de um sistema de recursos é mais produtivo, quando este fisicamente se caracteriza como uma unidade coesa, ao invés de constituído por partes descoordenadas (MACKEAN e OSTROM, 2001, p. 83).

À vista disso, Mckean e Ostrom (2001) destacam alguns fatores que demonstram a necessidade de se estimular esses regimes como forma também de manter a integridade dos recursos naturais. São eles:

- Indivisibilidade: alguns recursos devido suas características físicas não são passíveis de delimitações concretas. Entretanto, as autoras chamam a atenção que mesmo ecossistemas que aparentemente são mais fáceis de se limitar necessitam ser manejados de forma integral e sistêmica, de modo a garantir sua relevância ambiental. Aqui destacamos a territorialidade de comunidades caiçaras, cujos territórios se estendem ao mar, dificultando a divisão rígida de unidades.

- Incerteza na localização de zonas produtivas: considerando a dinâmica de produção de cada zona, fator muito ligado a variação do tempo e clima, abranger coletivamente uma área em toda sua extensão garante uma divisão dos riscos e benefícios. Essa dinamicidade é altamente significante para as práticas 
tradicionais caiçaras, considerando que lidam com variação de marés, correntes, ciclos biológicos de animais marinhos, períodos de defeso, etc.

- Eficiência produtiva através da internalização das externalidades: novamente destaca-se a necessidade de manejar os espaços naturais de forma sistêmica, considerando que a interdependência das parcelas de uma mesma área. As autoras dão o exemplo do manejo de bacias hidrográficas que dependem diretamente da saúde de florestas superiores e vice-versa. No caso especificamente do uso turístico da Ilha das Couves, esse fator se expressa na relação de dependência entre Ilha e Picinguaba, levando em conta que tanto os benefícios quanto os danos repercutem em ambos os locais.

- Eficiência administrativa: a institucionalização de regras coletivas de manejo permite sintonizar os diferentes usos nos sistemas de recursos. Além disso, destaca-se que permitem mitigar problemas relacionados ao monitoramento e a insuficiência de instrumentos administrativos para regular individualmente cada uso, como também possibilitam uma maior participação na criação de regras que se adaptam à realidade de maneira mais efetiva.

De acordo com Berge (2006), a discussão acerca da proteção ambiental e políticas relacionadas passou a incluir uma reflexão acerca dos direitos de propriedade comum mais recentemente. Frequentemente argumenta-se que a criação de áreas protegidas segmenta e por diversas vezes causa uma divergência entre os poderes de gestão e a distribuição de custos e benefícios. Nesse sentido, a internalização das externalidades perpassa necessariamente por uma unificação entre os níveis de gestão e resultados.

Murphree (2002 apud ZACHRISSON, 2009) sugere que existe uma certa afinidade essencial entre o comum e áreas protegidas. Conforme o autor, ambos se assemelham à medida que envolvem em seu cerne uma ideia de acesso coletivo e controlado, mesmo que suas legitimações, direitos e constituintes variem. Entretanto, essa interpretação envolve um esforço em extrapolar alguns entendimentos que assumem APs como áreas de exclusão geridas pelo Estado, compreendendo o seu potencial em abranger os princípios de design para a gestão sustentável de recursos em regimes de propriedade comum. 
De acordo com Ostrom (1990), a adoção parcial ou total desses princípios conduzem a graus de mudança, manutenção e consolidação das instituições no campo do uso comum. São eles: 1) demarcação bem definida das parcelas de uso de cada um;2) alinhamento das regras de exploração com as condições do espaço; 3) definição coletiva de regras; 4) monitoramento para respeito das normas; 5) reconhecimento da legalidade da organização pelo poder externo; 6) criação de mecanismos para resolver conflitos; 7) sancionar regras de maneira gradual conforme a gravidade das violações, para dar maior legitimidade à governança; 8) articulação e cooperação entre os níveis de gestão (SIMÕES et al., 2011; SILVEIRA e SAVAZONI, 2018).

É importante pontuar que a discussão acerca dos comuns e possibilidades de gestão, quando aplicadas à esfera de áreas protegidas, envolvem maiores níveis de complexidade considerando que são espaços administrados por órgãos específicos com seu próprio conjunto de regras e regulamentos. Com isso, as comunidades possuem oportunidades mais limitadas para negociar e alterar a política (PLUMMER e FENNEL, 2009). Entretanto, Olson (2009 apud WU et al., 2018) chama a atenção que desencorajar a ação coletiva nessas áreas contribui para dificultar que seus propósitos sejam mantidos, considerando que os indivíduos, ao serem excluídos dos benefícios da proteção de um patrimônio natural, se sentem pouco incentivados a reduzir suas atividades exploratórias.

A partir do que foi discutido nessa seção, compreende-se que mais que possível, o diálogo entre a garantia de acesso ao comum, a adoção de outros regimes de propriedade e o manejo de áreas protegidas é necessário. Esse debate propõe uma expansão de cenários factíveis, nos quais há a superação de modelos obsoletos e muitas vezes insuficientes de gestão, e o resgate dos direitos de propriedade de comunidades tradicionais - que um dia foram transferidos para grupos externos, transformando proprietários conscientes em exploradores ilegais.

\section{PROCEDIMENTOS TÉCNICOS DE PESQUISA}

Para que os objetivos deste trabalho fossem atingidos, foi escolhido o uso da abordagem qualitativa. De acordo com Godoy (1995), os fenômenos que envolvem seres 
humanos e suas complexas relações sociais inseridas em diversos ambientes, podem ser compreendidos mais profundamente se analisados em uma perspectiva integrada característica de estudos qualitativos.

A perspectiva socioambiental requer uma abordagem sistêmica, não limitada à análise de variáveis isoladas, mas de um modo capaz de apreender o todo e as partes nas suas relações com o todo, enxergando a complexidade que resulta da interação entre as partes. Além disso, a idéia de sustentabilidade requer que seja levada em consideração uma visão de futuro. A abordagem sistêmica não se limita aos aspectos estruturais, processuais e funcionais da realidade observada no presente. É preciso levar em conta a dimensão histórica, com aspectos de evolução, retrato do passado e projeção do futuro que, evidentemente, é objeto de conflitos, mas a partir do qual se define o que é desejável ou não (THIOLLENT e SILVA, 2007, p. 94).

Segundo Neves (1996), o direcionamento da pesquisa qualitativa pode ser estabelecido ao longo de seu desenvolvimento, conforme a interação entre o pesquisador e a situação que se objetiva estudar. $\mathrm{O}$ autor ainda pontua algumas características essenciais desse tipo de pesquisa:

1) $\mathrm{O}$ ambiente natural como fonte direta de dados e o pesquisador como instrumento fundamental;

2) O caráter descritivo;

3) O significado que as pessoas dão às coisas e à sua vida como preocupação do investigador;

4) Enfoque indutivo (NEVES, 1996, p. 1).

Destaca-se que empregar essa abordagem, que tem em si maior plasticidade e adaptabilidade, foi de extrema relevância para o melhor progresso deste trabalho, considerando que trata-se de um território constituído por práticas e transformações, o que faz emergir constantemente novos aspectos que por vezes resultaram em desvios na condução da pesquisa. 
Como método de pesquisa qualitativa, foi utilizado o estudo de caso a partir da perspectiva de Robert Yin (2015), o qual permite a investigação de um fenômeno contemporâneo em seu contexto real. $\mathrm{O}$ autor sugere que não há uma fórmula ideal para entender se esse método é o mais adequado para determinada pesquisa ou não, mas coloca que o uso do "como" ou do "por quê" nas questões norteadoras já é um bom indicativo. Além disso, aponta-se que o estudo de caso direciona-se a trabalhos que não exigem controle dos eventos comportamentais.

A essência de um estudo de caso, a tendência central entre todos os tipos de estudo de caso, é que ele tenta iluminar uma decisão ou um conjunto de decisões: por quê elas são tomadas, como elas são implementadas e com que resultados (SCHRAMM, 197130 apud YIN, 2015, p. 16).

A aplicação do estudo de caso quando realizada por meio da triangulação de dados, permite uma maior validação através do acesso a múltiplas fontes de evidências relacionadas ao mesmo fenômeno. $\mathrm{O}$ uso de diferentes fontes de dados possibilita o desenvolvimento de linhas convergentes de investigação, entretanto para que isso se concretize é necessário que as evidências sejam analisadas conjuntamente de modo a sustentar as descobertas e conclusões.

É importante ressaltar que essa pesquisa é também em parte uma pesquisa participante devido ao meu histórico de participação e vivências no território, que será melhor descrito a seguir. Soares e Ferreira (2006) explicitam que esse tipo de pesquisa implica essencialmente na inserção do pesquisador no contexto ou comunidade que está a estudar e na participação dos atores no processo do estudo. Nesse caso, o pesquisador torna-se até certo ponto um membro do grupo.

[...] consolida-se, na pesquisa participante, a prescrição não somente da inserção do pesquisador no grupo, comunidade ou cultura que pretende compreender, mas também a participação efetiva daqueles que estão a ser pesquisados no transcorrer de

\footnotetext{
${ }^{30}$ SCHRAMM, W. Notes on Case Studies of Instructional Media Projects, 1971.
} 
todo o processo de pesquisa, envolvimento que dá a esses últimos a titulação literal de co-autores da pesquisa (SOARES E FERREIRA, 2006, p. 98).

À vista do que se entende por pesquisa participante, esse trabalho não traz em sua construção a total aplicação da técnica, mas não é possível ignorar sua proximidade com alguns aspectos desta. Nesse sentido, destaca-se duas questões determinantes para essa interpretação: (i) não houve o envolvimento concreto da comunidade ou outro ator na estruturação do projeto ou na definição de objetivos, embora ambos tenham sido apresentados em reunião e disponibilizados para acesso; (ii) a minha atuação na área de estudo foi além do papel de pesquisadora, me tornando em certo momento ator do processo.

Como forma de aumentar a confiabilidade dos resultados, corroborando com Yin (2015), três técnicas para coleta de dados foram utilizadas: a) observação participante; b) pesquisa documental e; c) entrevista com os interlocutores. O percurso metodológico será melhor detalhado nas próximas seções de acordo com a ordem de desenvolvimento das etapas.

\subsection{INSERÇÃO NO TERRITÓRIO TRADICIONAL CAIÇARA DE PICINGUABA}

A minha inserção na área de trabalho dessa pesquisa, ao menos em caráter presencial, se deu primeiramente por meio da minha contratação ${ }^{31}$ como assessora socioambiental ao Grupo de Trabalho (GT) do Turismo de Base Comunitária de Picinguaba. Durante o desenvolvimento e amadurecimento da articulação para o ordenamento e gestão comunitária do turismo local, houve a necessidade de enriquecer a perspectiva ambiental do processo, que até então estava sendo delineado principalmente a partir de sua dimensão sociocultural.

\footnotetext{
${ }^{31}$ Essa contratação se deu através da Travessia Consultoria e Projetos Sustentáveis com o financiamento do Instituto Linha d'Água, ambos atores do processo em questão e que por isso serão melhor aprofundados na seção de resultados.
} 
À vista disso, entre dezembro de 2019 e março de 2020 coordenei um grupo formado por comunitários e parceiros para o desenvolvimento de dois produtos: Guia de Visitação Pública da Ilha das Couves - Ubatuba/SP, documento destinado a educação socioambiental dos turistas, cujo conteúdo aborda a contextualização cultural e ambiental do território, além de algumas recomendações e diretrizes associadas à práticas de mínimo impacto ecológico; Formulário de Pesquisa sobre a Experiência do Visitante, construído com o objetivo de entender a percepção socioambiental do turista após a realização do passeio turístico adequado aos moldes da gestão comunitária.

Para que a construção desses produtos se desse de forma mais integrada e correspondente ao cenário local, eu passei a participar das reuniões que ocorriam entre os parceiros para organização das demandas, avaliação e delineamento dos próximos passos. Além disso, organizei e participei da articulação dos atores responsáveis por contribuir na elaboração dos documentos que se deram de duas formas: reuniões presenciais e discussões via whatsapp.

É necessário esclarecer que anteriormente a minha chegada presencial ao território, o projeto de pesquisa que deu origem a este trabalho já havia sido definido e por isso, eu já havia entrado em contato com alguns interlocutores com o intuito de iniciar a minha entrada na área. Em função disso, ao iniciar a minha vivência de campo como assessora, iniciei também a coleta de dados por meio da observação e descrição com o uso de caderneta de campo.

O período correspondente à prestação da assessoria socioambiental foi essencial em alguns sentidos. Primeiro, possibilitou a redução da estranheza ou desconfiança por parte da comunidade com a minha presença no território, permitindo uma imersão mais profunda no local e em seu cotidiano. Martins (1996) aponta que adentrar à área de estudo de maneira participativa gera condições privilegiadas para que o processo de observação.

Os pesquisadores são levados a compartilhar os papéis e os hábitos dos grupos observados para estarem em condições de observar fatos, situações e comportamentos que não ocorreriam ou que seriam alterados na presença de estranhos (MARTINS, 1996, p. 270). 
Em segundo lugar, evidencia-se que o período conrrespondeu à fase inicial de execução das ações ${ }^{32}$ delineadas para o ordenamento do turismo e com a época de altíssima temporada, que ocorre entre dezembro e janeiro, considerada a mais crítica para a execução do novo regramento, devido a enorme pressão turística. Esse fato permitiu que eu observasse presencialmente esse processo, contribuindo para uma percepção mais densa das situações e atuações de cada interlocutor.

Em terceiro lugar, essa vivência viabilizou um mapeamento prévio principalmente das lideranças informais. Essas lideranças não ocupam cargos ou posições oficiais, como a presidência de associações ou a diretoria de um determinado grupo, mas possuem altos níveis de influência e respeito, passando a assumir papéis centrais como mediadoras dos interesses ou oradoras (SILVA, 2008; MONTEIRO e VIEIRA, 2008). A partir dessa percepção, essas lideranças foram incluídas na etapa da aplicação de entrevistas.

Entre dezembro de 2019 e novembro de 2020 foram realizadas cerca de 10 visitas ao território, com o tempo de permanência variando entre um a seis dias. As vivências foram realizadas durante a alta e altíssima temporada, em dias de semanas e finais de semanas, possibilitando a observação de dias mais intensos e mais calmos em relação à atividade turística. Salienta-se que entre março e outubro de 2020, as interações com as comunidades foram bruscamente diminuídas devido ao avanço da Covid-19, mantendose apenas virtualmente.

\subsection{PESQUISA DOCUMENTAL}

A pesquisa documental foi realizada com o intuito de encontrar informações complementares ou corroborar com o obtido por meio da aplicação das outras técnicas, de modo a alcançar o fenômeno estudado em sua totalidade. Os documentos escolhidos para análise (Tabela 1) foram identificados durante a observação em campo, e estão diretamente relacionados à regulação, limitação ou apoio ao ordenamento e gestão comunitária do uso público na área de estudo em questão.

\footnotetext{
${ }^{32}$ Essas ações foram delineadas pelo Plano de Ordenamento e Gestão Comunitária para o Uso Público Sustentável da Ilha das Couves do Território Tradicional Caiçara de Picinguaba, documento que será analisado nas próximas seções.
} 


\begin{tabular}{|c|c|c|}
\hline Documento & Fonte & $\begin{array}{l}\text { Mês/ano de } \\
\text { publicação }\end{array}$ \\
\hline $\begin{array}{l}\text { Capacidade de Carga Turística Ilha das Couves, } \\
\text { Ubatuba/SP }\end{array}$ & Ministério Público Federal & Maio/2018 \\
\hline $\begin{array}{l}\text { Plano de ordenamento e gestão comunitária para o uso } \\
\text { público sustentável da Ilha das Couves do território } \\
\text { tradicional caiçara de Picinguaba (POGC) }\end{array}$ & AMBP, АBPP E АВРТP & Set/2019 \\
\hline $\begin{array}{l}\text { Regras de ordenamento da visitação de uso público da } \\
\text { Ilha das Couves - Turismo de Base Comunitária da } \\
\text { Picinguaba, Ubatuba (SP) }\end{array}$ & AMBP, АВРP Е АВРТР & Nov/2019 \\
\hline Portaria Normativa n ${ }^{\circ} 315 / 2019$ & Fundação Florestal & Dez/2019 \\
\hline $\begin{array}{l}\text { Plano de ordenamento e gestão comunitária para o uso } \\
\text { público sustentável da Ilha das Couves do território } \\
\text { tradicional caiçara de Picinguaba }\end{array}$ & AMBP, ABPP E ABPTP & Maio/2020 \\
\hline $\begin{array}{l}\text { Proposta conjunta de nova normativa elaborada pelas } \\
\text { associações que operam no Turismo de Base } \\
\text { Comunitária Caiçara da Picinguaba }\end{array}$ & AMBP, ABPP E ABPTP & Set $/ 2020$ \\
\hline Portaria Normativa FF n ${ }^{\circ} 323 / 2020$ & Fundação Florestal & Out/2020 \\
\hline
\end{tabular}

Tabela 1. Lista de documentos que foram analisados.

\subsection{ENTREVISTA COM LIDERANÇAS FORMAIS E INFORMAIS}

No processo de reconhecimento local e acesso aos espaços informais faz-se necessária

a participação dos atores que constituem o território. Para alcançá-los, optou-se pela 
entrevista $^{33}$ semiestruturada como forma de interação e obtenção de informação. Segundo Boni e Quaresma (2005), esse tipo de questionário combina perguntas abertas e fechadas, possibilitando que o entrevistado discorra mais livremente sobre o tema, permitindo maior protagonismo.

Com base em uma revisão teórica sobre o assunto, a entrevista transpôs os seguintes componentes: i) identificação, caracterização e atuação dos atores e organizações no território; ii) percepção do entrevistado sobre a atuação dos demais atores; e iii) percepção socioambiental dos atores frente aos aspectos territoriais. Para além desses elementos, a entrevista possibilitou traçar de maneira mais precisa a temporalidade dos fatos. Os interlocutores entrevistados estão listados na Tabela $2^{34}$. O roteiro completo pode ser acessado no Anexo I.

\begin{tabular}{l|l}
\hline Atores & Origem \\
\hline Diretor executivo - Fundação Florestal & Setor público \\
\hline Gestão APAMLN - Fundação Florestal & Setor público \\
\hline Gestão PESM - Fundação Florestal & Setor público \\
\hline Presidente - AMBP & Terceiro Setor/Comunidade Tradicional Caiçara de Picinguaba \\
\hline
\end{tabular}

${ }^{33}$ Este trabalho foi aprovado pela Comissão Técnico-Científica (COTEC) do Instituto Florestal (processo SIMA nº 010.977/2019) e pelo Comitê de Ética (Plataforma Brasil) da EACH/USP.

${ }^{34}$ Pontua-se que a Secretaria de Turismo e a Secretaria de Meio Ambiente do município de Ubatuba não retornaram o convite para participar da pesquisa. O contato foi realizado através dos e-mails oficiais das secretarias e duas tentativas foram feitas. 
Vice-presidente - AMBP

Presidente - ABPTP

Vice-Presidente - ABPP

Interlocutor 1 - Liderança informal

Cor

Interlocutor 2 - Liderança informal

Comunidade Tradicional Caiçara de Picinguaba

Interlocutor 3

Vice-presidente - ATNU

Representante Caiçara - FCT de Angra,
Paraty e Ubatuba

Assessora jurídica - Travessia Consultoria e

Projetos Sustentáveis

Comunidade Tradicional Caiçara de Picinguaba

Terceiro Setor

Movimento Social

Setor privado

Assessora de turismo - Travessia

Consultoria e Projetos Sustentáveis

Setor Privado

Antropóloga - OTSS

Terceiro Setor

Coordenador executivo - Linha d'Água
Terceiro Setor 
Tabela 2. Lista de atores identificados que serão entrevistados.

A seleção dos atores que foram entrevistados seguiram um ou mais dos seguintes critérios: a) teve participação ativa e frequente nas reuniões do GT TBC de Picinguaba; b) foi determinante na criação e/ou institucionalização de diretrizes ou normas relativas ao processo estudado; c) teve papel relevante como apoiador no desenvolvimento do TBC; e d) foi citado em outras entrevistas como importante interlocutor a ser entrevistado.

As entrevistas com os 17 interlocutores foram realizadas no mês de novembro de 2020 presencialmente ou via Google Meet, a depender do acesso do entrevistado a internet e aos dispositivos necessários. As entrevistas presenciais foram gravadas por meio de um gravador de voz, e as virtuais através da opção de gravação de vídeo disponibilizada pela própria plataforma utilizada. Antes de cada entrevista foi entregue o Termo de Consentimento Livre e Esclarecido (Anexo II), cujo objetivo era apresentar a pesquisa e sua importância de forma clara e sucinta, alertar sobre os riscos de desvios na interpretação do pesquisador responsável e pronunciar o caráter voluntário da participação.

\subsection{SISTEMATIZAÇÃO E ANÁLISE DE DADOS}

A análise e sistematização de dados das entrevistas, se baseou no método de análise de conteúdo proposto por Bardin (1977). Segundo a autora, esse método constituise "como um conjunto de técnicas de análise de comunicações, que utiliza procedimentos sistemáticos e objetivos de descrição do conteúdo das mensagens", permitindo que a construção de significados que os sujeitos ou documentos externalizam em seus discursos sejam compreendidos.

A análise apresentou três fases primordiais. A primeira relativa à pré-análise, consistiu na organização e recorte do material, fixando o corpus da investigação. Nessa etapa os documentos levantados para futura análise foram filtrados, entendendo que nem todos tratavam diretamente da questão da pesquisa. Essa seleção se deu a partir dos seguintes filtros: ano de publicação, abrangência do conteúdo e relevância para o processo 
em foco nesse estudo. Outra ação realizada durante a pré-análise foi a transcrição das entrevistas.

A segunda fase constituiu a descrição analítica dos dados, em que o processo de ordenamento e gestão comunitária foi descrito com base na pesquisa documental e nas entrevistas, possibilitando a identificação de alguns nós, isto é, de alguns pontos centrais de conflito que foram explorados com o intuito de entender as divergências e convergências entre as ideias e conteúdos advindos dos atores, documentos e da etapa de observação em campo.

Na última fase se deu o tratamento dos resultados, onde houve a interpretação dos dados a partir do referencial teórico, possibilitando uma análise mais abrangente desses nós. O confronto dos resultados com a bibliografia permitiu um aumento da amplitude de reflexão, favorecendo uma possível extrapolação de dados para outras realidades e tornando-os assim, dados mais significativos.

A análise dos documentos foi realizada de maneira paralela ao conteúdo das entrevistas, como estratégia complementar para se obter o percurso do processo estudado de forma mais precisa e detalhada. Como os documentos selecionados possuem diferentes origens, a exploração documental também foi realizada de maneira comparativa com o objetivo de compreender possíveis discordâncias e convergências entre o que foi proposto por cada ator.

\section{ORDENAMENTO E GESTÃO COMUNITÁRIA DO TURISMO NO TERRITÓRIO TRADICIONAL CAIÇARA DE PICINGUABA}

Esta seção se dedicará a retomar e analisar o processo de ordenamento e gestão comunitária do turismo no Território Tradicional Caiçara de Picinguaba a partir dos dados coletados e assim atingir os objetivos propostos para este trabalho.

\subsection{O AVANÇO TURÍSTICO E OS CONFLITOS TERRITORIAIS: UM RECORTE TEMPORAL ENTRE 2016 E 2018}

O histórico de conflitos no Território Tradicional Caiçara de Picinguaba estimulado pelo avanço das atividades de turismo, como foi apresentado anteriormente, já possui uma 
trajetória de pelo menos quatro décadas. Entretanto, o cenário de superexploração que despertou atenção dos atores envolvidos na área devido ao seu caráter predatório, se inicia em meados de 2016, quando a área sente um considerável aumento de turistas a procura de roteiros turísticos para a Ilha das Couves (Figura 9 e 10). Como descrito no POGC,

Para atender a demanda, muitos caiçaras de Picinguaba e de comunidades vizinhas, compraram embarcações para atuarem nos serviços de transporte. Um grande número de agências de turismo náutico e terrestre passou a comercialização de passeios de visitação e mergulho na Ilha sem qualquer controle estatal de um turismo que se caracteriza de massa (escunas, ônibus, lanchas, botes etc) e predatório (AMBP et al., 2020, não paginado).

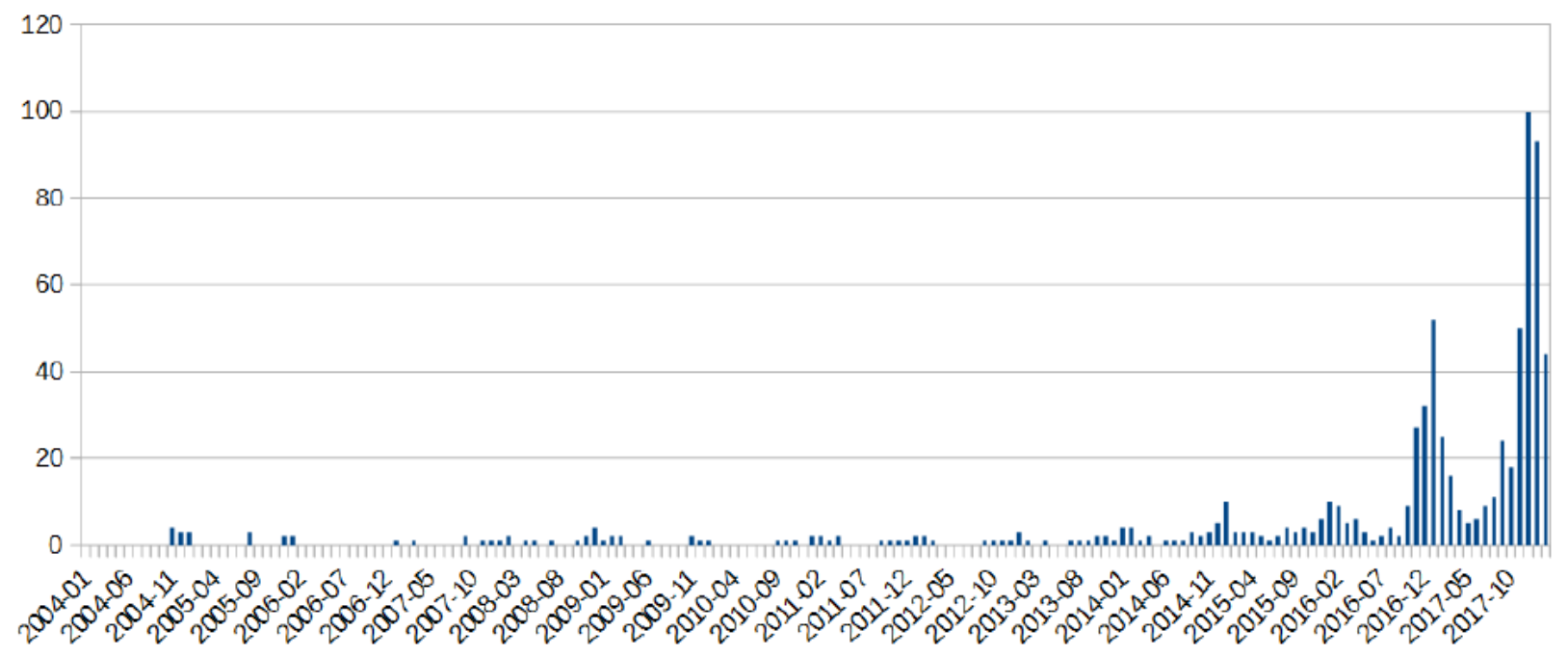

Figura 9. Gráfico sobre a quantidade de buscas do termo "Ilha das Couves" no Google entre 2004 e 2017. O eixo Y refere-se à porcentagem de buscas de acordo com o maior número já registrado. Fonte: Estudo CCT (2018).

Segundo relatos dos interlocutores, a intensificação turística no território se deu principalmente devido ao alto volume de divulgação, realizada majoritariamente por operadoras de turismo náutico externas ao território de Picinguaba. De acordo com o relatado pelo vice-presidente da ATNU, há pelo menos 10 anos as empresas de turismo náutico de Ubatuba se utilizam da Ilha, porém ele aponta que desde 2016

[...] a Ilha das Couves tomou um vulto grande com algumas divulgações, no nosso entender errôneas porque acabou criando uma situação horrível. Chegou a dar lá umas 3000 ou 4000 
pessoas num dia só. [...]Teve dia da gente ir lá com o pessoal no barco e não ter como descer.

Não houve um levantamento preciso e detalhado sobre o número máximo de visitantes que ocuparam simultaneamente a Ilha nesse período, contudo, conforme Belgamo et al. (2020), as notícias veiculadas sobre o assunto apontam que houveram até 5000 pessoas ao mesmo tempo no local.

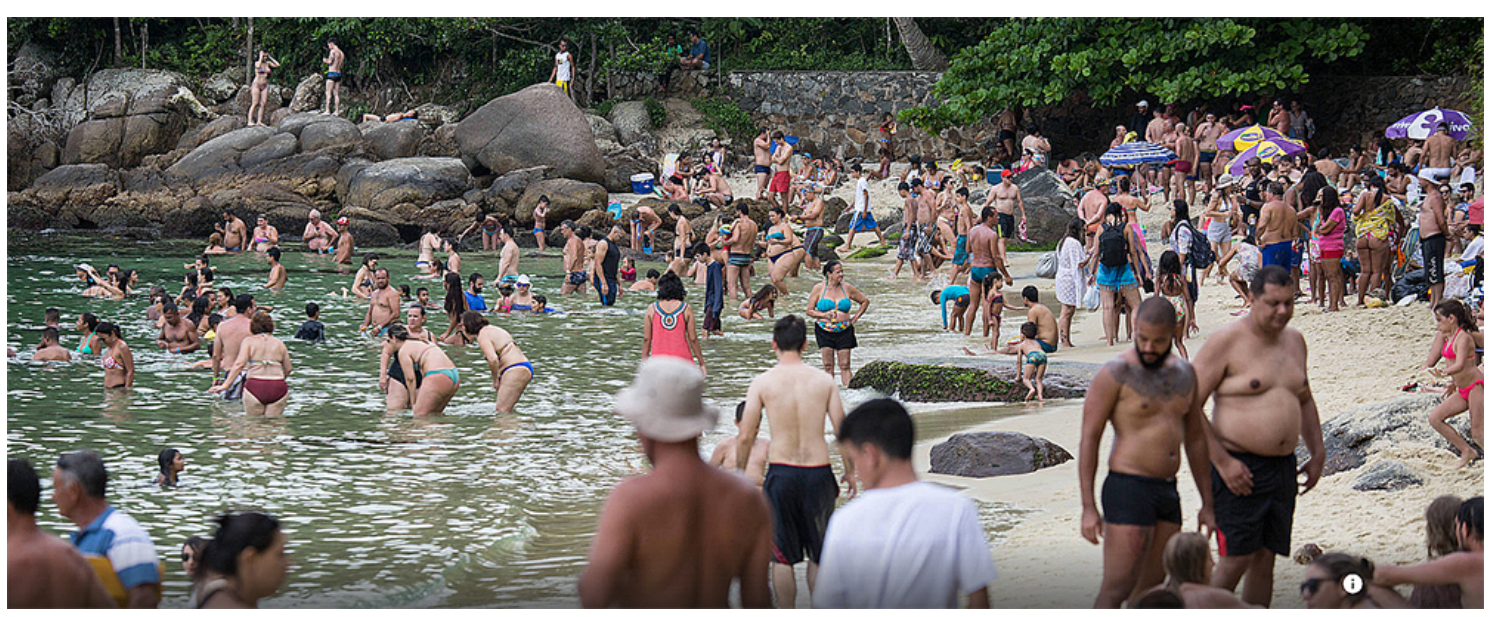

Figura 10. Praia de Fora na Ilha das Couves em 2018. Fonte: Folha de São Paulo, $2018^{35}$.

Essa alta procura reverberou em Picinguaba intensificando os conflitos principalmente entre a comunidade. A maioria das famílias caiçaras locais passaram a vender passeios para a Ilha, com diferentes preços. Havia uma clara divisão sexual do trabalho, onde as mulheres vendiam os passeios e os homens faziam a travessia com seus barcos. Para isso, as mulheres da comunidade se posicionavam ao longo da estrada vicinal para oferecer o passeio aos turistas que chegavam em seus carros. A disputa no processo de venda se tornou cada vez mais intenso, fazendo com que as caiçaras chegassem a ocupar o trevo de ligação entre a vicinal e a Rio-Santos e, consequentemente, fossem submetidas aos risco de acidentes e assédio.

\footnotetext{
${ }^{35}$ Folha de São Paulo. Superlotado, paraíso do litoral norte vira pesadelo de turistas. Disponível em: $<$ https://www1.folha.uol.com.br/cotidiano/2018/02/superlotado-paraiso-do-litoral-norte-de-sp-virapesadelo-de-turistas.shtml>
} 
Santana (2014) aponta que a divisão sexual do trabalho é frequente em diferentes comunidades ligadas à pesca. De maneira geral, as atividades consideradas femininas referem-se à terra, mesmo quando são em ambientes aquáticos, essas atividades são desenvolvidas em praias, rios ou outras áreas próximas. As práticas que ocorrem em alto mar são tradicionalmente masculinas. Essa naturalização das relações de trabalho homem-mulher em comunidades caiçaras se estende para outras dimensões no território, como é possível observar no turismo local, onde majoritariamente os homens assumem a posição de barqueiro ${ }^{36}$.

O cenário, além de colocar as mulheres em posição de vulnerabilidade, resultava numa venda altamente desproporcional entre os barqueiros, onde alguns realizavam um alto número de passeios e outros realizavam poucos ou nenhum. Isso porque nem todos os barqueiros contavam com a colaboração de mulheres para abordar os clientes ainda no morro ou tinham receio de falar diretamente com eles.

$\mathrm{Na}$ verdade, a gente trabalhava todo mundo fora, cada um por si. [...] cada uma focou no seu marido, no seu trabalho. Eu tinha, a outra também fazia para o marido e aqueles barqueiros que a mulher não trabalhava aqui eram prejudicados porque não chegava até eles. Não dava tempo (Vice-presidente da AMBP).

Outra questão abordada nos relatos, foi que o bairro de Picinguaba virou nesta época o estacionamento para a Ilha das Couves. Segundo as falas dos interlocutores da comunidade, os espaços foram ocupados por um alto volume de carros dos turistas que acessavam o território para chegar na Ilha. Essa dinâmica de visitação também causava um trânsito intenso na estrada de acesso ao bairro, prejudicando a movimentação dos moradores, sendo os maiores afetados os que dependiam do transporte público, já que em meses de mais alta temporada (dezembro, janeiro e fevereiro) os ônibus não chegavam até lá.

\footnotetext{
${ }^{36}$ Durante o período em que estive em campo, não foi observado embarcações conduzidas pelas mulheres da comunidade. Entretanto, não é possível afirmar que só homens ocupam essa posição, considerando que ouvi relatos que algumas mulheres já trabalharam como barqueiras.
} 
Para além dos inúmeros carros que ocupavam a vila, esse conflito era potencializado pelo fluxo intenso de ônibus turísticos, que traziam grandes números de turistas para fazer o passeio à Ilha. Sobre isso, o POGC comenta que não havia qualquer controle por parte da Prefeitura Municipal sobre o número de transportes que entravam no território. O Plano ainda aponta que, apesar disso, os ônibus pagavam uma taxa à Prefeitura, que não era revertida em benefícios à comunidade, como exemplo na melhoria da infraestrutura ou prestação de serviços públicos (AMBP et al., 2019).

Devido aos olhares turísticos estarem todos direcionados à Ilha das Couves, o bairro de Picinguaba passou a receber um número minoritário de visitantes que chegavam ao território com o objetivo de passar o dia ali, desfrutando das praias da vila e consumindo no comércio local. Isso passou a impactar negativamente os restaurantes, quiosques e outros estabelecimentos. Conforme o narrado pela vice-presidente da AMBP, ao mesmo tempo que a Ilha abrigava milhares de turistas, Picinguaba se via vazia de gente.

Por outro lado, a família caiçara responsável pelo o único restaurante da Ilha enfrentava uma dinâmica de trabalho intensa, considerando o número alto de turistas que consumiam ao mesmo tempo. Pontua-se que mesmo tendo alto faturamento durante a alta temporada, a interlocutora 2 - caiçara e dona do restaurante - relata que contribuiu para denunciar o cenário ao MPF.

Tudo era insustentável. Mesmo com a gente e as meninas no bar, era muita gente. Estressou todo mundo. Era 100 ou 500 pessoas, todo mundo querendo tudo na hora. Um bar só na Ilha, era muita gente. Então gerou conflito entre nós, entre os barqueiros, entre os escuneiros, entre quem ia lá durante o dia, virou uma bagunça (Interlocutora 2).

Os impactos ambientais originados desse boom turístico, de acordo com a AMBP et al. (2019), foram causados a partir de diferentes vetores, listados no quadro a seguir (Figura 11). Conforme o relatado pelo presidente da AMBP, entre os vetores o pior era o acúmulo exorbitante de lixo. 
O pior impacto era o lixo, tanto na vila como na ilha. Quando eu trabalhava sozinho, eu e meu irmão, por dia era 2 a 3 sacos de lixo. Eu e meu irmão trazia da ilha. Fora os outros 38 barqueiros e nem todos faziam isso (Presidente da AMBP).

Eu acho que impacto assim, o lixo é pior. Era muita quantidade de pessoas no mesmo lugar, danifica um pouco, mas mais o lixo. Eu com a minha associação a gente limpava a rua. [...] A gente trazia o lixo e um rapaz da comunidade mesmo juntava as latas e levava o lixo pra gente. A gente fazia um rateio, pegava 10, 20 reais e dava pra ele (Presidente da ABPTP).

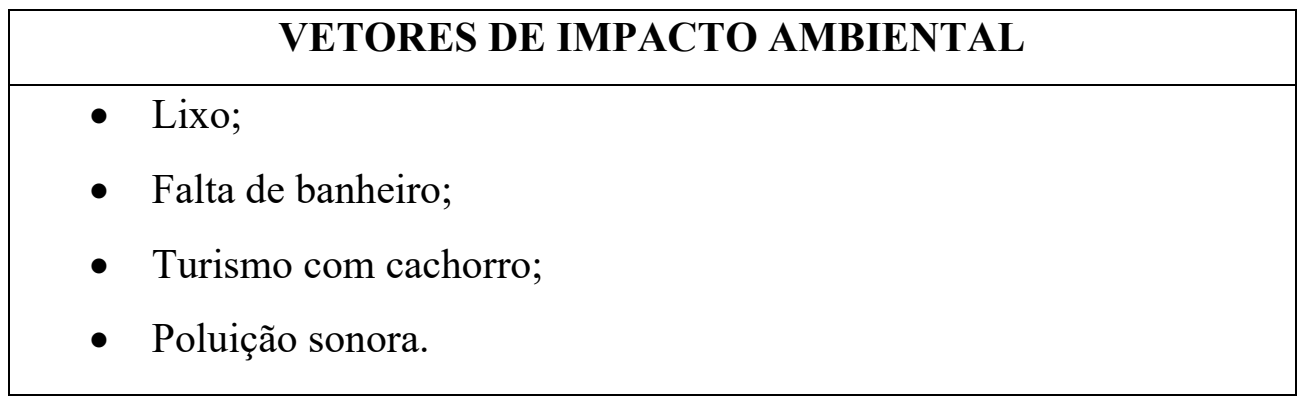

Figura 11. Principais vetores de impacto ambiental no período entre 2016-2019. Fonte: AMBP et al., 2019.

Segundo dados fornecidos pela prefeitura municipal de Ubatuba, na baixa temporada são geradas em média 75 a 85 toneladas de resíduos sólidos por dia. $\mathrm{Na}$ alta, esse valor duplica, produzindo cerca de 150 a 160 toneladas de resíduos por dia (UBATUBA, 2014). O município, de forma geral, sofre com a debilidade na coleta do lixo e com a dificuldade de destinação, tendo que enviar para aterros sanitários de cidades no Vale do Paraíba, como Jambeiro e Tremembé. No entanto, essa situação se faz mais crítica para as comunidades, que por estarem mais distantes e possuírem estradas precárias de acesso (que lotam facilmente), convivem com volumes enormes de lixo durante a alta temporada.

Em relação ao saneamento, mais especificamente aos banheiros, não há estrutura adequada para receber um número tão alto de turistas. Na praia de Picinguaba não há banheiros públicos, contudo há uma diversidade de restaurantes que auxiliam na diminuição da pressão ocasionada pelo déficit de infraestrutura. Já na Ilha, há apenas os dois banheiros do restaurante local, que estão localizados na praia de Terra. Para a utilização desses banheiros os visitantes devem consumir ou pagar à parte. Na outra praia, 
a de Fora, não há banheiro. Essa realidade acabou gerando uma grande presença de dejetos nas trilhas, matas e mar.

Além dos dejetos aparentes, os banheiros do restaurante da Ilha estão conectados a uma fossa negra, considerada o tipo menos seguro para o meio ambiente e comunidade local. Nesse tipo de fossa, os dejetos e águas residuárias são descartados diretamente ao subsolo, alcançado por meio de escavações profundas e sem qualquer tipo de revestimento em suas laterais e base.

No interior da fossa ocorrem reações na matéria orgânica presente nas fezes, em virtude da intensa atividade microbiana, com a liberação de um líquido de odor desagradável e também com altas concentrações de nitrato e coliforme fecais, denominado chorume. Este líquido se infiltra nas paredes da fossa e percola através do solo podendo atingir e contaminar as águas subterrâneas (FAUSTINO, $2011^{37}$ apud SOUZA et al., 2015, p. 33)

A grande quantidade de excremento em locais impróprios, além de gerar odores desagradáveis, ameaçavam diretamente a saúde das pessoas e salubridade das águas subterrâneas e, consequentemente, dos ecossistemas aquáticos. Bordignon et al. (1998), aponta que a contaminação do lençol freático pode ser mais perigosa do que de águas superficiais, considerando que a renovação natural é lenta e pode propagar-se por grandes distâncias. Ainda em relação a água, a família caiçara que ocupa a Ilha possui uma caixa para a coleta de água advinda de uma nascente e, segundo narrado pela Interlocutora 2, haviam turistas que entravam na caixa para se banhar, poluindo a água que eles utilizavam.

Além dos citados na Figura 10, destaca-se que havia um fluxo intenso de embarcações oriundas tanto de Picinguaba quanto de outras praias e centro, que transitavam sem qualquer ordenamento, pressionando diretamente os ecossistemas

${ }^{37}$ FAUSTINO, A. S. Estudo físico-químico do efluente produzido por fossa séptica biodigestora e o impacto do seu uso no solo. Tese de doutorado. Universidade Federal de São Carlos, 2011. 
marinhos e costeiros. Havia também um descontrole sobre os tipos de embarcações que transitavam ao entorno da ilha e não se sabia ao certo a quantidade ou a origem delas (AMBP et al., 2019).

[...] eu nunca vi a ilha desse jeito. Nasci aqui e nunca. E a degradação do meio ambiente também? Não tinha mais vida marinha na ilha. Era só gente! Não vinha mais peixes na beira da praia, não via tartaruga. Não tinha mais nada (Vice-presidente da AMBP).

A movimentação de embarcações característica do turismo náutico compõe um dos fatores que explicam essa escassez de vida marinha no local. Conforme Vieira (2019), a ação de barcos perto das áreas costeiras gera uma intensificação dos ruídos que atingem o fundo do ambiente marinho. Quando o ruído subaquático é excessivo, seu efeito pode gerar a mudança comportamental das espécies e danos físicos ou fisiológicos. Esse efeito é potencializado quando, além das embarcações, a praia recebe um nível desproporcional de pessoas. Ainda segundo a autora, a consequência disso às espécies pode ser a adaptação aos elementos antropogênicos ou a fuga de seus territórios.

Além do descontrole das embarcações, havia também uma falta de ordenamento sobre a venda dos passeios. O que os atores tinham o conhecimento é que as vendas eram realizadas pelas comunidades, tanto de Picinguaba (maioria) quanto algumas vizinhas (minoria), e por um grande número de agências localizadas na região central de Ubatuba. Após um levantamento demonstrado no POGC, sabe-se que cerca de 18 empresas se utilizavam da área, a maioria delas realizam o passeio com escunas, um tipo de embarcação que geralmente comporta mais de 100 pessoas. O POGC, porém, aponta que houveram informações de outras empresas fora de Ubatuba, em Paraty e São Paulo, por exemplo, que também exploravam a Ilha, mas não constam no levantamento (AMBP et al., 2019).

Já os passeios vendidos pelas comunidades são realizados por barcos motorizados que comportam em média 10 pessoas. Da comunidade de Picinguaba, aproximadamente 40 barqueiros realizavam o transporte à Ilha. Destaca-se que no contexto do turismo desordenado e predatório, haviam comunitários atuando com certas irregularidades, entre elas: problemas com os documentos da embarcação ou com a habilitação para conduzir e 
menores de idade pilotando barcos (AMBP et al., 2020). Esse fato, além de colocar os visitantes em risco durante a travessia, representava uma situação de vulnerabilidade para as famílias que dependiam disso, considerando que a qualquer momento a documentação ou a própria embarcação poderia ser apreendida.

Nas comunidades vizinhas, havia o uso em bem menor escala quando comparado a Picinguaba ou ao centro de Ubatuba, representando uma baixa interferência no cenário de pressão ao território. Segundo o POGC, as comunidades externas ao território que comercializavam o passeio saiam principalmente das praias do Estaleiro, Ubatumirim e Almada (Figura 12) (AMBP et al., 2019). Um dos motivos para a escassa participação dessas comunidades refere-se à distância ${ }^{38}$ entre outras praias e a Ilha, considerada alta para ser realizada com embarcações menores.

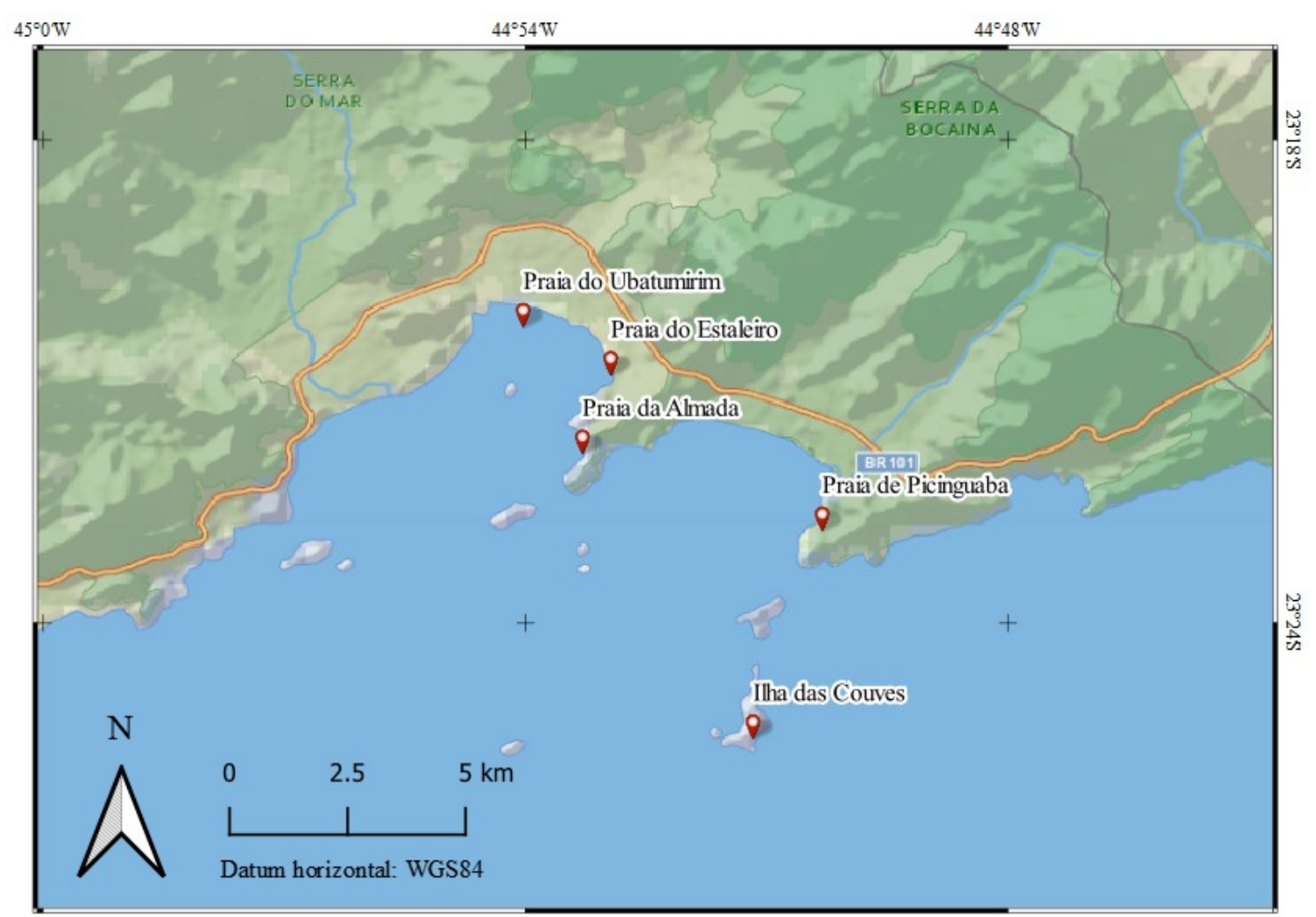

Figura 12. Localização das praias da Almada, Estaleiro e Ubatumirim em relação a Picinguaba e Ilha das Couves. Fonte: elaborado pela autora no software QGIS.

\footnotetext{
${ }^{38}$ A praia da Almada fica cerca de 7,5 km da Ilha das Couves; o Estaleiro, 8,8 km; e Ubatumirim, 10,6 km.
} Essas distâncias foram estimadas em linha reta. 
Apesar de estar inserida na APAMLN, como é possível entender na Figura 2, integrar à zona de amortecimento do PESM e estar nos limites territoriais do município de Ubatuba, a Ilha das Couves é de domínio da União. Com isso, durante os anos de boom turístico houve uma certa nebulosidade sobre a competência de cada órgão em relação a adoção de ações voltadas ao ordanamento do uso da Ilha. Essa falta de clareza sobre as respectivas responsabilidades converteu-se, em diversos momentos, no abandono do território e desamparo à comunidade, sem que ações mais direcionadas fossem tomadas para frear o processo de superexploração. Sobre isso, o diretor executivo da FF e a Procuradora da República comentaram:

Eu acho que lá era o típico caso de cachorro sem dono, sabe? Era da comunidade, era do trade turístico, era da União, era APA... [...] Então, eu acho que é uma falha de todos, porque tinha a comunidade que hiperexplorava, tinha o setor turístico que hiperexplorava, tinha o Estado que não conseguia articular, tinha a União que não decidia, acho que todo mundo errou e errou feio, só que uma hora todo mundo falou "gente, não dá mais, vamos tentar superar isso" e a gente conseguiu (Diretor executivo - FF).

A área é zona de amortecimento de um Parque Estadual, do Parque Estadual da Serra do Mar alí na Picinguaba e ela também está dentro da APA Marinha do Litoral Norte, então ela está alí coincidindo com duas unidades de conservação estaduais, que são de gestão da FF. Também está dentro do município de Ubatuba que tem ali a sua competência para fazer sua gestão. Quando chega para nós do Ministério Público, isso já meio que significa que os atores principais pelo gerenciamento daquele bem público não estão funcionando bem, tem alguma questão que não está sendo bem gerida, então foi isso que aconteceu (Procuradora da República).

De acordo com o POGC, havia um posicionamento da Fundação Florestal em relação a impossibilidade de atuar em uma ilha de domínio da União, argumento que, segundo o 
descrito, não se justifica, considerando a competência do órgão em regular o uso em UCs, sejam elas terrestres, marinhas ou insulares (AMBP et al., 2020).

A Fundação Florestal falava assim pra nós nas reuniões "olha, a gente não pode fazer nada, porque a Ilha é de nível federal, ela não é do nosso domínio, é do domínio do Estado, então a gente não pode fazer nada" (|Interlocutora 1).

Não tínhamos nada. Ninguém ajudava nem atrapalhava. Era só a gente da comunidade mesmo, não tinha essas coisas. Não tinha APA Marinha, ninguém vinha aqui (Vice-presidente da AMBP).

Em relação a Prefeitura Municipal, houveram relatos que nesse período os diálogos com a comunidade foram mais frequentes com o intuito de tentar encontrar meios de promover a gestão do território, porém essas conversas não eram pautadas por uma perspectiva de empoderamento comunitário.

O desenvolvimento desse contexto de turismo de massa e omissão do poder público afetou diretamente as relações pessoais entre os membros da comunidade, refletindo na fragmentação das relações de cooperação e solidariedade. Nota-se que esse quadro foi intensificado pela ação de agentes turísticos externos à comunidade, mas que em alguns casos já possuiam pousadas ou restaurantes ali, que pressionavam e assediavam os caiçaras e incentivavam a especulação turística no território (AMBP et al., 2019). Conforme o relatado pela antropóloga do OTSS e moradora da vila:

O modo de vida das comunidades tradicionais caiçaras é baseado, originalmente, nos princípios da sustentabilidade e da solidariedade. Com as influências negativas do modelo de desenvolvimento hegemônico, o equilíbrio se desfaz, e as atividades passa a ser potencialmente destrutivas.

As divisões internas dentro das comunidades aparecem justamente quando alguns abandonam os princípios fundantes. $\mathrm{Na}$ economia de subsistência familiar caiçara, as relações solidárias já eram um princípio. A produção agrícola familiar podia ser compartilhada ou trocada por outras coisas que não 
dispunham. Não havia essa desigualdade material que tem hoje, com a existência de pessoas com muito mais poder aquisitivo que que outras dentro da comunidade.

A chegada das casas de veraneio dentro da comunidade e a cadeia do turismo criou a possibilidade do trabalho assalariado, monetizou as relações, e os próprios parentes passaram a ter condições materiais muito diferentes. Aí complicou. A desunião vem em grande medida desse fato.

No caso da Ilha das Couves, a competição se acirrou, e a consequência foi o aumento da pressão sobre os recursos da natureza.

Dada essa conjuntura, a partir de 2016 o MPF passou a receber denúncias sobre irregularidades na operação turística na Ilha que vieram de diferentes origens, mas principalmente de visitantes.

No ano de 2016, uma das demandas relacionadas à meio ambiente e comunidades tradicionais que mais surgiu na Procuradoria, foi sobre a exploração predatória do turismo na Ilha das Couves. Havia muita reclamação. Nós temos um veículo de peticionamento, de denúncia pra todo cidadão, aberto no nosso site e muitos turistas e visitantes da Ilha encaminhavam reclamações sobre a superlotação da Ilha, a poluição da Ilha com resíduo sólido, muito lixo, passeio turístico que não possuía habilitação do condutor, da embarcação, a embarcação não era segura, não possuía colete. Enfim, uma série de questões que vão desde a locomoção para a Ilha até a Ilha propriamente dita (Procuradora da República).

Com isso, houve a chegada do MPF ao território que se deu, segundo a Procuradora, por meio do contato com a comunidade para iniciar um diálogo. Em 2017, no primeiro semestre, foi dado início a um processo guiado pelo MPF, com o objetivo de enfrentar os problemas ali estabelecidos. 
Entre as medidas tomadas pelo Ministério naquele ano, destacam-se duas: limitação do número de visitantes na Ilha para o máximo de 600/700 pessoas e parceria com a Marinha para a facilitação do curso $\operatorname{ESEP}^{39}$ e regularização das habilitações para a condução de passageiros até a Ilha das Couves (AMBP et al., 2020). É importante pontuar que devido ao contexto de conflitos, quebra de relações e baixa articulação entre a comunidade, o cumprimento do limite máximo estabelecido foi dificultado. A respeito desse momento, o presidente da ABPTP comentou:

Então, o MPF veio aqui na Picinguaba e pediu pra gente se organizar. A comunidade da Picinguaba vai poder trabalhar uma quantidade de 600 pessoas por dia. Tava uma bagunça. Você não tem noção o que era isso aqui em 2017. [...] Não tinha associação de barqueiros, aí organizaram. Eu lembro que o MPF veio já perto do verão, pro verão estourar. [...] O MPF se propôs a ajudar a organizar. Só que a galera aqui brigava muito e não deu certo.

Essa associação de barqueiros sobre a qual ele comenta diz respeito à Associação de Barqueiros e Pescadores de Picinguaba (ABPP), criada nos primeiros meses de 2017 (AMBP et al., 2020). Um pouco adiante, ainda neste ano, outra organização foi criada, a Associação de Barqueiros e Pescadores Tradicionais de Picinguaba (ABPTP). Essa segmentação originou-se de um conflito entre os caiçaras sobre a relação entre a pesca e turismo. Houve uma discordância entre eles sobre quem, na época, deveria trabalhar com o turismo ou não. Alguns caiçaras eram vistos como "empresários" porque possuíam embarcações de pesca maiores ou em maior número.

O pessoal começou a se organizar quando a gente saia pra pescar. $\mathrm{Na}$ época eu ficava muito nervoso na reunião porque o pessoal apontava muito a gente como empresário. Quando a gente chegou pra exercer o turismo, eu lembro que a gente tava no final da pesca já pra exercer o turismo, e a gente chegou numa sala de votação e todo mundo falando não pra 5 pessoas, pra tirar habilitação. A

\footnotetext{
${ }^{39}$ O Curso Especial de Segurança de Embarcações de Passageiros (ESEP) teve a finalidade de qualificar os barqueiros para pilotar embarcações empregadas na atividade de turismo.
} 
ESEP que o MP trouxe. E eles não entenderam em si o que o MP falou. Não é pra rejeitar o pessoal da própria comunidade, é pra se organizar toda a comunidade. Aí em 2017 mesmo quando ela falou dos 600, a primeira associação se organizou, eu também fui correr atrás do meu direito, que todo mundo tem direito, me organizei, montei minha associação, na qual eu sou presidente hoje. Então, eles trabalhavam 600 pessoas eles e a gente trabalhava 600 pessoas a gente (Presidente da ABPTP).

As discordâncias resultaram em uma divisão simbólica e concreta do território, considerando que as associações passaram a atuar em praias ${ }^{40}$ distintas da vila. Pelas palavras do presidente da ABPTP, “a gente não passava da igreja Adventista ${ }^{41}$ pra lá e eles não passavam da Adventista pra cá”. Acerca dessa questão, a antropóloga do OTSS e moradora de Picinguaba, avalia:

Então você tem um modo de vida cujos princípios são sustentáveis, mas que a partir da chegada de influências externas ele passa a ser potencialmente destrutivo e aí você tem as divisões internas dentro das comunidades justamente porque tem aquele caiçara, que abandona um pouco os princípios fundantes, que eram solidariedade, divisão, os caras tinham muita coisa na roça e ele trocavam. A economia solidária era um princípio já. Você não tinha desigualdade de ricos e pobres. Todo mundo tinha as mesmas coisas, comia as mesmas coisas. A vida material das comunidades era muito parecida. As pessoas dentro da comunidade. Quando começa a chegar o pessoal de fora, começa a ter diferença de rico e pobre entre parentes e aí complicou. Porque daí começa uma inveja, uma separação, uma desunião. E

\footnotetext{
40 A vila de Picinguaba possui algumas praias pequenas divididas por formações rochosas. Entre elas, destacam-se duas: a Praia do Empório (ou dos Pescadores), de onde sai os barcos sentido Ilha das Couves, e a Praia do Lanço, onde a ABPTP ocupou durante o período de desentendimento entre associações.

${ }^{41}$ A igreja Adventista fica localizada na rua principal de Picinguaba, na orla, e foi um importante local para a organização comunitária. Esse assunto será detalhado mais adiante.
} 
daí começam os processos de pressão sobre os recursos da natureza.

Ainda em relação ao limite estabelecido pelo MPF em 2017, a vice-presidente da AMBP pontua que foi proposto um esquema de rodízio de embarcações para que o número de visitantes fosse respeitado. Contudo, nesse período não houve apoio do poder público para fiscalizar o processo. Com isso, evidencia-se o papel da vice-presidente da AMBP e outras mulheres, que na época não assumiam nenhum cargo oficial, considerando sua atuação na tentativa de organizar a saída e padronizar os valores, conforme foi solicitado pela Procuradora. Segundo seu relato, o limite foi respeitado por alguns meses, porém no período de altíssima temporada o número não se manteve.

Quando chegou em dezembro, não, em novembro, 5 ou 6 barqueiros saíram fora da associação e foram pra aquela praia que a gente fazia a travessia e começaram a barquear. A gente continuou aqui. A gente continuou insistindo nos cinquenta reais certinho pra todo mundo ganhar e eles lá quarenta, trinta reais. E nós aqui olhando e a fiscalização não vinha. A Marinha não vinha fiscalizar. A gente ligava e não vinha. [...] Os barqueiros viram eles fazendo mais barato do lado de lá e se bandearam. Aí começou a bagunça. Eu falei, eu não vou ficar mais. Se não tem físcalização pra eles, não tem punição pra eles, vai ter pro barqueiro que é documentado? Aí eu saí e as meninas tudo saíram. Cada um pegou seu marido. Aí acabou (Vice-presidente da AMBP).

Ainda em 2017, nesse princípio de movimento rumo ao ordenamento turístico, a AMBP fortaleceu uma série de reivindicações para que a Prefeitura Municipal contribuísse na organização e fiscalização do trânsito na via de acesso a Picinguaba. A partir dessa pressão, foram instaladas placas de orientação e houve fiscalização regular por parte da Prefeitura, garantindo que pelo menos houvesse a chegada do transporte público à vila (AMBP et al., 2019).

Já no primeiro semestre do ano seguinte, 2018, o MPF formou uma comissão técnica com o objetivo de realizar o estudo de Capacidade de Carga Turística (CCT) da 
Ilha das Couves e assim determinar com maior precisão o número máximo de visitantes que podem ocupar a Ilha simultaneamente. A comissão foi composta por representantes da gestão pública municipal, estadual e federal, incluindo os gestores do PESM e APAMLN. O resultado do estudo foi apresentado em agosto de 2018 por meio de uma reunião pública ocorrida no centro de visitantes do Parque. Segundo descrito no POGC, o trabalho não envolveu em nenhum estágio representantes da comunidade tradicional de Picinguaba (AMBP et al., 2019).

O estudo foi desenvolvido a partir do método Cifuente $(1992)^{42}$ e as variáveis consideradas foram: superfície total da área visitada, espaço ocupado por cada visitante e tempo relativo a alta e baixa temporada. De acordo com o documento técnico gerado nesse processo, "o conceito de capacidade de suporte foi criado dentro das ciências agrárias para o manejo de pastos e posteriormente aplicado a gestão da visitação de áreas protegidas”. Após a realização dos cálculos, foi estabelecido que o limite máximo permitido para a Ilha das Couves seria o de 177 visitantes.

Para a realização do cálculo da capacidade de suporte foram utilizados dois dos níveis propostos na metodologia escolhida: a capacidade de carga física $(\mathrm{CCF})$ e a capacidade de carga real (CCR). A CCF refere-se ao limite máximo de visitas em determinada área, que no caso da Ilha das Couves foi calculada a partir do seu espaço físico disponível. A CCR diz respeito à CCF corrigida com alguns fatores de correção (FC) estipulados com base nas especificidades do atrativo.

O cálculo da CCF foi realizado por meio da seguinte fórmula:

$$
C C F=\frac{S}{S}
$$

Onde: $\mathrm{S}=$ superfície total do atrativo;

$\mathrm{s}=$ espaço ocupado por visitante.

A superfície total da Ilha das Couves (S) refere-se à medida da área de suas duas praias, tendo a Praia de Fora, $1833 \mathrm{~m}^{2}$, e a Praia de Terra, $804 \mathrm{~m}^{2}$. Para a variável s foi adotado

\footnotetext{
${ }^{42}$ CIFUENTES, M. Determinación de Capacidad de Carga Turística em áreas protegidas. Centro Agronômico Tropical de Investigación y Enseñanza - CATIE, Turrialba, Costa Rica. 1992.
} 
o valor sugerido por Ruschmann et al. (2008) de $10 \mathrm{~m}^{2}$ por usuário, que segundo o estudo reflete a área ocupada por um turista, levando em conta conforto e qualidade da sua experiência. A partir desses dados, o cálculo final da CCF se deu da seguinte forma:

$$
C C F=\left(\frac{1833}{10}\right)+\left(\frac{804}{10}\right)=184+80=264
$$

Após encontrado o valor de 264 pessoas simultaneamente como CCF, foi calculado o valor da CCR. O FC aplicado referiu-se ao período de baixa temporada turística na área em questão, que se dá entre maio e agosto (120 dias). Portanto, o resultado final do CCR foi encontrado com a plicação do procedimento a seguir.

$$
F C=1-\left(\frac{M l}{M t}\right)
$$

Onde: $\mathrm{Ml}=$ magnitude limitante (120 dias de baixa temporada $)$

$\mathrm{Mt}=$ magnitude total (365 dias no ano)

$$
\begin{gathered}
F C=1-\left(\frac{120}{365}\right)=0.6712 \\
C C R=C C F \times F C
\end{gathered}
$$

$$
C C R=264 \times 0.67=177 \text { pessoas simultaneamente }
$$

O desenvolvimento deste estudo gerou certo incômodo em uma parte dos atores, cujas críticas compreendiam a desconsideração da dimensão sociocultural do território, a falta de participação comunitária e o fato da Ilha das Couves ter sido analisada isoladamente e não integrada ao território tradicional caiçara de Picinguaba. Através das entrevistas foi possível entender que esse é um ponto de grande divergência entre os atores. Abaixo estão descritos alguns comentários que apareceram em relação a essa ação específica.

Teve uma reunião, a gente teve que se juntar rápido e fomos pra reunião ver qual era o limite da Ilha das Couves. Aí quando chegamos lá tomamos um susto, 177 pessoas com tudo. Aí como que foi feito esse estudo que ninguém da comunidade participou? Pra fazer um estudo desse tinha que ter alguém da comunidade acompanhando (Vice-presidente da AMBP). 
A gente queria ter participado do grupo do estudo, com o conhecimento comunitário de todas as questões ambientais. A gente tem aquele conhecimento que é nato, que é nosso. Mas o grupo não quis que a gente fizesse parte (Interlocutora 1).

Sugerimos ao MPF que incorporasse caiçaras de Picinguaba à equipe do estudo de capacidade de suporte para agregar o conhecimento tradicional. Imaginamos que seria acatado porque o MPF se mostrava favorável a participação da comunidade no processo. Entretanto, fomos surpreendidos pelo argumento de que os técnicos que estavam operando a metodologia, não tinham como absorver o conhecimento tradicional no estudo. Isso foi ruim. Quando volta o estudo com o resultado, era esperado que ele sofresse retaliações. Muitos não ficaram convencidos como se chegou ao número de 177 pessoas, do ponto de vista da sustentabilidade ambiental da ilha. Avalio que não houve tempo ou competência técnica da equipe responsável para acolher o conhecimento tradicional no estudo de capacidade de suporte. Faz pelo menos 50 anos que a antropologia vem demonstrando a complexidade e efetividade técnica dos conhecimentos dos povos e comunidades tradicionais, principalmente no que se refere aos sabres ligados aos animais, às plantas e suas relações com variáveis climáticas e ciclos naturais (Antropóloga - OTSS).

Até ouve um pedido deles de participação no grupo de trabalho, mas infelizmente não foi possível porque a questão era muito técnica, e era esse o objetivo. Técnica no sentido de científica mesmo, precisava saber espécies, era uma questão mais acadêmica e por isso eu entendi que não era possível a participação deles naquela fase (Procuradora da República).

A aplicação desse tipo de estudo apresenta limitaçãoes metodológicas que interferem diretamente nos resultados obtidos. Conforme Stankey (1985 apud TAKAHASHI E CEGANA, 2005), esse metodologia tornou-se obsoleta a medida que foi 
sendo comprovado que os impactos gerados pelo turismo estão mais relacionados ao comportamento dos visitantes do que a quantidade em si. Restringir o ordenamento do uso turístico de uma área protegida apenas à visão quantitativa vai em sentido contrário ao desenvolvimento de uma atividade turística aliada a qualidade, na qual a experiência e satisfação do visitante são colocadas em planos secundários.

Outra questão apontada como limitante dessa metodologia diz respeito à incapacidade de englobar aspectos socioeconômicos ou de promovê-lo de forma participativa. Segundo Seabra (2005), esses fatores abalam a credibilidade do estudo, considerando que o Brasil apresenta um cenário sociocultural e econômico mais complexo se comparado às áreas nas quais essa metodologia foi proposta inicialmente. Novamente, observa-se a importação de ideias e práticas aplicadas à Parques ${ }^{43}$ estadunidenses, ainda que essas áreas apresentem contextos territoriais distintos.

Apesar das críticas ao estudo, foi observado que ainda não há na literatura científica - pelo menos não de forma popularizada - metodologias que proponham a abrangência de outros aspectos além do biofísico. Outro ponto também levantado é que apesar de não ser suficiente por si só, não há como negar a importância de se limitar quantitativamente o uso turístico. Para Boullón (2002 apud SEABRA, 2005) mesmo que não haja uma preocupação voltada à conservação ambiental por parte do visitante, se houver um número determinado, os possíveis distúrbios causados pelos turistas tendem a ser irrisório frente a capacidade do meio em diluir tais transtorno.

Como alternativa aos estudos de capacidade de suporte turístico convencionais, o Instituto Chico Mendes de Conservação da Biodiversidade (ICMBio) tem aplicado o Número Balizador de Visitantes (NBV). O método abrange de maneira mais ampla as especifidades da área na qual o número será aplicado. Questões como espaço disponível, infraestrututra, serviços oferecidos, equipamentos necessários, segurança e qualidade da experiência dos visitantes devem ser respondidos e posteriormente quantificados. O NBV

\footnotetext{
43 “A aplicação desta metodologia em vários locais nos Estados Unidos da América deveu -se ao fato de que, em 1978, o decreto 95-625 exigia que cada Parque Nacional norte-americano desenvolvesse estudos de capacidade de carga das áreas de uso público" (TAKAHASHI E CEGANA, 2005, p. 208).
} 
é um número dinâmico que varia de acordo com os avanços ou retrocessos das condições de manejo (ICMBIO, 2011).

$\mathrm{Na}$ ocasião de apresentação do estudo, foram expostos também três cenários que estavam sendo pensados e amadurecidos pelo poder público para que o objetivo de regramento do turismo fosse alcançado. Cada um dos cenários, listados a seguir, será melhor aprofundado na próxima seção.

- Cenário 1 - Termo de Autorização de Uso Sustentável (TAUS) para a comunidade tradicional caiçara de Picinguaba;

- Cenário 2 - Cessão à Prefeitura Municipal de Ubatuba para a criação de Unidade de Conservação de Proteção Integral;

- Cenário 3 - Cessão a pessoas físicas ou jurídicas, observado o procedimento licitatório nos moldes do art. 18, § 5 , da Lei $\mathrm{n}^{\circ}$ 9.636, de 15 de maio de 1998.

\subsection{CENÁRIOS PROPOSTOS PARA O ORDENAMENTO TURÍSTICO}

Após o desenvolvimento do estudo de CCT, o qual encontrou o número de 177 pessoas como limite máximo de uso simultâneo, possíveis cenários foram pensados visando um modelo de exploração turística que acomodasse e possibilitasse essa limitação. À vista disso, as seções a seguir direcionam-se à aprofundar cada um deles, buscando entender seus preceitos, variáveis e até que ponto foram continuados.

\subsubsection{Termo de Autorização de Uso Sustentável (TAUS)}

De acordo com o relatório técnico do estudo de CCT da Ilha das Couves, o cenário que envolve o TAUS para a comunidade tradicional caiçara de Picinguaba referia-se a possibilidade de promover uma gestão comunitária do turismo, conduzida pelos moldes do turismo de base comunitária. Para que esse cenário fosse encaminhado, a comunidade deveria assumir uma série de compromissos, apresentados na tabela abaixo (Figura 13).

\section{CONDICIONANTES PARA O TAUS}


- Atender ao previsto neste trabalho no que se refere à capacidade de suporte;

- Informar aos visitantes sobre os atributos ambientais e fragilidades da Ilha, inclusive que a ilha está inserida na APAMLN;

- Garantir, por meio de informações e pela própria conduta, que os visitantes adotem práticas de mínimo impacto, não deixando resíduos na ilha, evitando pisoteio nas bordas das trilhas, não abrindo novos acessos e etc;

- Regularizar as embarcações e as habilitações dos membros da associação que realizam o transporte de visitantes;

- Realizar ações de monitoramento das condições do ambiente e da satisfação dos visitantes;

- Implantar e realizar a manutenção da infraestrutura necessária, com anuência do órgão gestor (Fundação Florestal) e mediante a licenciamento ambiental se exigível, a saber: Vila de Picinguaba - receptivo, o qual deverá ser composto por estrutura móvel; e Ilha - sistema de esgotamento sanitário e sistema de abastecimento de água;

- Instalar placas informativas, com anuência do órgão gestor;

- Contribuir com a fiscalização, acionando as instituições parceiras sempre que houver necessidade e abordando visitantes com vistas a coibir atividades em desacordo com as normas;

- Realizar a gestão de resíduos sólidos;

- Elaborar Plano de contingência de risco do uso público;

- Trabalhar junto a Prefeitura Municipal de Ubatuba e a Marinha do Brasil para a delimitação e regulamentação da área para banhistas e para embarque, desembarque e fundeio de embarcações, respeitando as normas estabelecidas.

Figura 13. Lista de condicionantes previstas no Estudo CCT para que o TAUS destinado à comunidade fosse aprovado.

A trajetória político-administrativa do TAUS tem forte ligação com ações direcionadas à regularização fundiária de populações ribeirinhas cujos territórios estão sobrepostos às áreas da União no norte do Brasil. O instrumento foi desenvolvido pela Superintendência do Patrimônio da União (SPU) com esta finalidade. O marco legal da sua trajetória se deu em 2010, com a aprovação da Portaria SPU 89, que prevê o TAUS 
como instrumento para reconhecimento e regularização fundiária de comunidades tradicionais habitantes de áreas da União (MARCONDES e RAIMUNDO, 2019).

Art. $1^{\mathrm{o}}$ Disciplinar a utilização e o aproveitamento dos imóveis da União em favor das comunidades tradicionais, com o objetivo de possibilitar a ordenação do uso racional e sustentável dos recursos naturais disponíveis na orla marítima e fluvial, voltados à subsistência dessa população, mediante a outorga de Termo de Autorização de Uso Sustentável - TAUS, a ser conferida em caráter transitório e precário pelos Superintendentes do Patrimônio da União (SPU, 2010, p. 91).

Segundo Marcondes e Raimundo (2019), o TAUS se insere a um projeto mais amplo que busca o desenvolvimento socioeconômico pautado na inclusão socioterritorial. No litoral norte de São Paulo, as experiências iniciais ocorreram no âmbito das comunidades pesqueiras, visando a regularização de espaços que abrigam ranchos de pesca. Em 2012, a comunidade caiçara da Ilha do Montão de Trigo, em São Sebastião, se tornou a primeira a receber a outorga do TAUS para desenvolver o turismo e pesca. Três anos depois, o instrumento foi concedido para mais seis comunidades habitantes da Ilhabela.

O TAUS destina-se ao uso exclusivo da unidade familiar ou comunidade tradicional, sem a possibilidade de transferência à terceiros. Conforme o relatado pela Procuradora da República, a expectativa quanto a comunidade de Picinguaba, era que fosse concedido à eles a exclusividade do uso da Ilha das Couves. Ela ainda apontou que este cenário era o prioritário entre todos.

O primeiro cenário, que nós trabalhamos inicialmente com a comunidade, era o cenário prioritário de todo esse trabalho com o Ministério Público. A gente chamou de cenário prioritário para o desenvolvimento do turismo de base comunitária pela comunidade da Picinguaba. Exploração exclusivamente por ela, de forma autônoma, no seu próprio território tradicional, através de um TAUS a ser concedido pela Secretaria de Patrimônio da União. Então, através desse termo, a comunidade teria a cessão 
do uso desse bem, que é um bem público federal. A comunidade conseguiria explorar o turismo de forma exclusiva (Procuradora da República).

A aplicação desse instrumento no contexto territorial de Picinguaba permitiria a concretização da comunidade caiçara como sujeito do processo de exploração de recursos naturais para o turismo. Contudo, algumas dificuldades e barreiras foram encontradas, impedindo o avanço e materialização desse cenário. Marcondes (2018) assinalam que há uma série de desafios na interpretação da execução e gestão do termo quando os conflitos estão sedimentados às áreas marinhas usadas pelo turismo. Isso deve-se ao fato de que envolve uma variedade de atores e a gestão do uso e ocupação é normalmente externa ao território.

Esse debate pode ser aplicado ao caso de Picinguaba, considerando que a gestão territorial deve-se principalmente à Fundação Florestal e há uma gama de atores que compõem a realidade local. Entre as divergências sobre o cenário proposto, ressalta-se a discordância quanto ao uso exclusivo pela comunidade. Houve, principalmente por parte da FF, posições contra a exclusão ou proibição dos agentes turísticos da região central de Ubatuba. Conforme foi opinado, o ordenamento a partir de uma condução que não abriga os setores comerciais e visa destinar toda possibilidade de uso à comunidade foi considerado pela FF e Prefeitura equivocado.

A possibilidade de aplicação do TAUS abrange a construção de uma realidade que conte com a participação do trade turístico, porém sem perder o foco no objetivo de ascensão comunitária a posição de tomadores de decisão no processo turístico. Contudo, o instrumento exige alguns aspectos das comunidades que o tornam mais árduo, como organização, conhecimento sobre direitos tradicionais, lidar com procedimentos burocráticos, maior profissionalização e envolvimento no turismo, e a continuidade da luta para a garantia do controle e acesso aos recursos naturais e da reprodução sociocultural (MARCONDES e RAIMUNDO, 2019).

Esses aspectos representaram uma limitação à comunidade de Picinguaba que, na época, não conseguiu formatar um plano compreendendo todas as condicionantes dentro do prazo proposto pelo MPF para o ordenamento do uso na temporada 2018/2019, 
fazendo com que esse cenário não se concretizasse. Desse modo, foi dado prosseguimento aos outros dois cenários.

Como não vinha nada da comunidade, uma resposta, um comprometimento, as lideranças comunitárias estavam um pouco desanimadas também o que é normal, tem hora que a gente cansa, tendo em vista as dificuldades naquele momento. Então a gente meio que deu continuidade aos cenários (Procudora da República).

Sobre isso, reitera-se que as três associações locais possuíam um baixo nível de articulação, com pouca confiança, reciprocidade e coesão, o que impossibilitou que o TAUS e outras ações anteriores estabelecidas pelo MPF se efetivassem, remetendo o proposto por Merten et al. (2011) (seção 4.1) acerca do potencial do capital social de ligação em favorecer o delineamento e consenso de estratégias para a gestão dos conflitos territoriais e a promoção da ação coletiva.

Ao mesmo tempo observa-se que as principais propostas realizadas entre 2016 e 2018, chegaram ao território a partir de uma perspectiva hierárquica, sem que a comunidade participasse da sua elaboração e maturação. Esse modelo, quando adotados a territórios tradicionais, pode originar medidas maiores e mais complexas do que a comunidade está apta a suportar. Nesse sentido, evidencia a etapa de compreensão dos antecedentes territoriais, proposta por Selin e Chavez (1995) (seção 4.2), para que seja possível construir a partir daí uma modelo de parcerias de turismo que abranja as circunstâncias locais.

\subsubsection{Cessão à Prefeitura Municipal de Ubatuba}

O segundo cenário pensado para a gestão turística da Ilha das Couves, foi a criação de uma unidade de conservação de proteção integral municipal a partir do determinado pelo SNUC. Para que esta alternativa fosse viabilizada, a Prefeitura Municipal teria que se comprometer com algumas condições (Figura 14) elaboradas com base nas normas e regulamentos previstos no SNUC e na realidade local. 
No cenário dois a Prefeitura receberia a cessão da Ilha para instituir uma unidade de conservação municipal, porque a APA é uma unidade de conservação de uso sustentável, ela possui limitações bem amplas comparadas a uma UC de proteção integral. Então o município teria a cessão desse bem pra realizar a criação da UC com uso mais restritos (Procuradora da República).

\section{CONDICIONANTES PARA UC MUNICIPAL}

- Envolver a Comunidade Tradicional da Vila de Picinguaba na gestão do uso público, seja por meio de termo de autorização, permissão, concessão ou outros contratos, para atividades relacionadas a gastronomia, transporte, mergulho, experiências, guias de turismo e demais usos;

- Elaborar Plano Emergencial de Uso público, o qual deve conter, obrigatoriamente projeto de educação ambiental;

- Instalar placas informativas (informações sobre a UC, proibições e demais informações pertinentes à categoria de manejo);

- Contratação de efetivo para monitoria ambiental, pessoal para limpeza e vigilância;

- Atender ao previsto neste trabalho no que se refere à capacidade de suporte;

- Disponibilizar informações aos visitantes sobre os atributos ambientais e fragilidades da Ilha;

- Garantir, por meio de informações e pela própria conduta, que os visitantes adotem práticas de mínimo impacto, não deixando resíduos na ilha, evitando pisoteio nas bordas das trilhas, não abrindo novos acessos e etc;

- Realizar o cadastro de embarcações regularizadas para transportar os visitantes; 
- Realizar ações de monitoramento das condições do ambiente e da satisfação dos visitantes;

- Buscar apoio para a realização de pesquisas científicas para caracterização do ambiente terrestre e marinho, principalmente em relação à fauna e flora, para que a presença de espécies endêmicas e ou ameaçadas possam ser identificadas e contribuam com as decisões de manejo;

- Implantar e realizar a manutenção da infraestrutura necessária, com anuência do órgão gestor (Fundação Florestal) e mediante a licenciamento ambiental se exigível, a saber: Vila de Picinguaba - receptivo, o qual deverá ser composto por estrutura móvel; e Ilha - sistema de esgotamento sanitário e sistema de abastecimento de água;

- Garantir a fiscalização;

- Realizar a regularização fundiária de seu território;

- Realizar a gestão dos resíduos sólidos;

- Elaboração de Plano de contingência de risco para o uso público, e;

- Trabalhar junto à Marinha do Brasil para a delimitação e regulamentação da área para banhistas e para embarque, desembarque e fundeio de embarcações, fiscalizando as normas estabelecidas.

Figura 14. Lista de condicionantes previstas no Estudo CCT para a cessão da áre para a Prefeitura Municipal de Ubatuba.

Destaca-se que, ao contrário do TAUS, a consolidação de uma nova área protegida no território tradicional de Picinguaba restringiria a participação comunitária a um campo mais simbólico, considerando que assumiriam uma posição de prestadores de serviços e não de tomadores de decisão no processo de gerenciamento da área. Diferente do proposto por Tosun (2006) (vide seção 4.1), assume-se que esse cenário dá prosseguimento e fortalece, pelo menos a partir do seu delineamento teórico, a característica hierárquica (top-down) do campo decisório sobre o qual de maneira geral a gestão de APs se constrói.

Outra questão sobre a instituição de uma UC de proteção integral na Ilha das Couves diz respeito a fragilidade sob a qual a família caiçara que ocupa o local a anos seria exposta. Em sua construção teórica, o SNUC define que esse tipo de UC não admite habitantes e moradia, contudo há diversos Parques que possuem comunidades inseridas à sua área, como é o caso do próprio PESM. Mesmo assim, há algumas partes do SNUC 
que fundamentam ações como exclusão ou realocação (BRASIL, 2000). Ademais, entende-se que a autonomia da família em gerir seus bens sofreria uma maior subtração, levando em conta que atualmente lida com o regramento de uma área de uso sustentável.

Segundo o relatado pela Procuradora durante a entrevista, houve uma reunião entre MPF e Prefeitura Municipal de Ubatuba com intuito de especular a perspectiva de uma UC municipal, contudo o prefeito respondeu negativamente. Com isso, a atuação do MPF direcionou-se a dar seguimento ao terceiro cenário proposto.

\subsubsection{Cessão à pessoas físicas ou jurídicas}

À vista do não prosseguimento dos outros cenários, um terceiro foi pensado visando a cessão da Ilha para pessoas físicas ou jurídicas que se comprometessem com a preservação da sociobiodiversidade da área. De acordo com o relatório técnico do estudo CCT, esse processo seria respaldado pela Lei 9.636, de 15 de maio de 1998, mais especificamente, no artigo 18 , parágrafo $5^{\circ}$.

Essa Lei é responsável por dispor sobre a regularização, administração, aforamento e alienação de bens imóveis de domínio da União, e o artigo 18 trata diretamente da prática de cessão. O parágrafo ao qual o relatório se refere, descrito a seguir, garante que a cessão possa ser realizada mediante a um conjuntos de encargos ou obrigações.

$\S 5^{\circ} \mathrm{Na}$ hipótese de destinação à execução de empreendimento de fim lucrativo, a cessão será onerosa e, sempre que houver condições de competitividade, serão observados os procedimentos licitatórios previstos em lei e o disposto no art. 18B desta Lei (BRASIL, 1998, não paginado).

O disposto pelo o artigo 18-B coloca algumas condições para a efetivação da cessão, entre elas: (i) prazo máximo de 30 anos, com direito a prorrogações por iguais períodos; (ii) formalização da cessão por meio de termo ou de contrato, o qual constará os compromissos estabelecidos e; (iii) cancelamento do contrato caso o imóvel seja submetido a uso diverso do estabelecido em contrato (BRASIL, 1998).

É necessário explicitar que essa Lei concerne exclusivamente aos bens da União, diferindo das leis que embasam processos concessórios de áreas protegidas, tratados na 
seção 4.1 deste trabalho. Entretanto, os dois processos possuem alta similaridade. Se analisarmos a Lei Estadual 16.260, de 29 de junho de 2016, que embasaria uma possível concessão das áreas protegidas nesse território, é possível observar que ambas dizem respeito a possibilidade de contrato administrativo entre o ente público e particular, garantindo o uso do bem público de forma exclusiva e para uma finalidade específica por pelo menos 30 anos.

Para além das semelhanças descritas acima, ambas quando sobrepostas à territórios tradicionais permitem um determinado modo de cercamento do patrimônio natural e cultural, originado na dilatação da propriedade privada que reverbera nos padrões e formas de acesso (DARDOT e LAVAL, 2020). No caso em questão, o que estava sendo deliberado era uma abertura para a entrada legal e ampla de uma agente externo, cujos poderes confrontariam diretamente a existência daquela comunidade, que há décadas possui uma relação de dependência com a Ilha, sendo esta, inclusive, parte do mosaico patrimonial histórico cultural de Picinguaba (vide seção 1.4).

Evidencia-se também que a fragmentação em nível de gestão do bairro de Picinguaba e Ilha das Couves, permitiria um maior desequilíbrio entre a distribuição dos custos e benefícios, considerando que a maneira como o uso é promovido e incentivado na Ilha traz consequências explícitas ao bem-estar das famílias caiçara que habitam Picinguaba, como foi possível perceber na seção 6.1 .

A aprovação desse cenário dependeria de um série de recomendações e compromissos que abarcariam os objetivos propostos para a área e antecipariam algumas responsabilidades socioambientais para com o território. A lista de condicionantes é semelhante a do cenário anterior (Figura 14), salvo duas diferenças: seria obrigatório a contratação de um efetivo mínimo de funcionários, preferencialmente membros da comunidade local para fortalecimento e manutenção desse grupo; e não ficaria sob responsabilidade do cessionário o cadastro de embarcações que realizam o transporte.

A vinculação da ideia de inclusão de comunidades tradicionais por meio do trabalho assalariado expõe algumas noções destoantes do colocado por Frey (2001) como uma inclusão social concreta. De acordo com o autor, a inclusão liga-se ao sentido de emancipação comunitária, conquistada a partir da democratização dos campos decisórios, fortalecimento político-organizacional da comunidade e da garantia de gestão coletiva 
dos bens comuns territoriais. A contratação de caiçaras como funcionários da atividade turística seria mais um desafio para a reprodução sociocultural do território, considerando que a comunidade tem um ritmo de trabalho próprio, sendo muitas vezes ligado aos horários da pesca.

A perspectiva de cessão da Ilha à iniciativa privada chegou a receber encaminhamentos iniciais, por meio da articulação entre a SPU e FF, conforme conta a Procuradora da República no trecho descrito a seguir.

Eu dei seguimento ao cenário com duas reuniões com a SPU e a Fundação Florestal para que eles trouxessem algum tipo de minuta, algum cenário alí sobre como poderia ser cedido pra iniciativa privada a Ilha.

Ainda de acordo com ela, esse cenário teve que ser prosseguido porque havia uma necessidade urgente em resolver a questão do desgaste ambiental da Ilha das Couves e, por mais que houvesse o interesse em garantir o uso comunitário, não era possível permitir a continuidade da destruição de um território que é intergeracional.

Eu sempre fui muito transparente nos diálogos que eu tive com a comunidade desde o início, se vocês não assumirem a gestão sustentável, não há outra saída que não ceder a Ilha pra um terceiro. Porque o que não é possível, nem na defesa das comunidades tradicionais a gente consegue pautar isso, é que uma das gerações dessas comunidades destrua o território das futuras (Procuradora da República).

Neste momento, é necessário destacar o papel da Prefeitura Municipal de Ubatuba que, segundo alguns relatos, apesar de não se interessar pela a instituição de uma UC municipal, tentou fortalecer o cenário de cessão à iniciativa privada sem qualquer contato com a comunidade.

A prefeitura acabou sendo, na prática, um verdadeiro inimigo do processo de ordenamento, por formalizar uma proposta de privatização da ilha, de cessão onerosa da ilha para aliado do prefeito [...] e talvez com alguma participação no financiamento 
da campanha do prefeito. Então a prefeitura, ela formaliza um processo de proposta de cessão onerosa da ilha, ou seja, da exploração turística da ilha sem qualquer diálogo com a comunidade caiçara (Assessora jurídica - Travessia).

Chegou um momento em que a Prefeitura vai até o MPF e fala “olha, Picinguaba não deu conta do cenário 1, então nós queremos fazer a parceria público-privada". [...] e nem fomos consultados, nem conversaram com a gente sobre esse assunto (Interlocutora $1)$.

No início de 2019, ao saber que este cenário estava sendo continuado, a comunidade voltou a se articular com o MPF para tentar barrar o processo e retomar a possibilidade de assumirem a Ilha por meio de uma gestão coletiva (AMBP et al, 2019).

A gente pegou e falou assim "galera, é o seguinte, acordem e vamos correr pra porta do MPF de novo, a coisa está andando”. E aí a gente bate na porta do MPF, "a gente quer conversar sobre isso, nós não terminamos a primeira etapa e vocês avançaram o sinal". [...] Como a gente não tinha afirmado nada no papel, era sempre nas reuniões, foi uma tentativa só de "boca" e nada firmado no papel como a gente deveria ter feito desde o início. $\mathrm{O}$ MPF falou assim "vocês querem a Ilha das Couves?" e a gente falou "lógico que a gente quer, a gente precisa dela", daí eles responderam pra gente voltar a conversar, porque o cenário avançou mesmo, já estava indo pra privatização. E aí a gente começou todo uma correria para reverter o processo (Interlocutora 1).

Consoante ao que foi narrado pela Interlocutora 1, o MPF deu um prazo de quinze dias para que as três associações juntas manifestassem interesse em assumir o ordenamento do turismo na Ilha e apresentassem, em um prazo de 60 dias, um plano de ação exequível ainda na temporada 2019/2020. 
Esse momento é marcado como o início de uma articulação rumo ao protagonismo caiçara para a gestão coletiva do território tradicional de Picinguaba. Entretanto, como será aprofundado adiante, esse avanço não representou o retorno ao primeiro cenário sugerido, considerando que não houve a outorga do TAUS e sim a adoção de instrumentos jurídicos mais pontuais e flexíveis.

\subsection{ORDENAMENTO TERRITORIAL: ATORES, AÇÕES E INSTRUMENTOS PARA O DESENVOLVIMENTO DO TBC PICINGUABA}

O ano 2019 representou um período decisivo no direcionamento dos rumos do território tradicional caiçara de Picinguaba. Em junho de 2019, a primeira ação concreta para a garantia da Ilha das Couves foi tomada. A comunidade junto ao Fórum de Comunidades Tradicionais de Angra, Paraty e Ubatuba protocolou a carta exigida pelo MPF, na qual declara interesse em implementar uma gestão turística pautada pelos princípios do turismo de base comunitária (AMBP et al., 2019). Essa fase marca a entrada concreta e ativa do FCT ao território, tornando-se em conjunto às associações comunitárias protagonista do processo.

Ao longo dessa seção, os atores que, por meio da articulação horizontal com a comunidade, construíram o capital social de ponte no desenvolvimento do turismo comunitário, serão apontados e aprofundados. Conforme demonstram Marteleto e Silva (2004) e Merten et al. (2011) (seção 4.1 e 4.2), será possível compreender que o fortalecimento do capital social de ligação e avanço para além de suas fronteiras foi determinante para que a possibilidade de gestão comunitária se concretizasse.

Associações comunitárias. O primeiro e mais importante ator identificado para o ordenamento do turismo em Picinguaba e Ilha das Couves é a comunidade caiçara, organizada em três associações. A mais antiga delas, a Associação de Moradores do Bairro de Picinguaba (AMBP), foi formada em 1996 e desde então vêm atuando para a resistência e representação caiçara no território. A Associação de Barqueiros e Pescadores de Picinguaba (ABPP) e a Associação de Barqueiros e Pescadores Tradicionais de Picinguaba (ABPTP), foram criadas em 2017, no início e no final do ano, respectivamente. 
Luchmann (2012), ao analisar as diferentes perspectivas sobre associações comunitárias, destaca algumas vertentes que assumem movimento associativo ao aprofundamento e ampliação da democracia. Considerando a complexidade dos fenômenos sociais modernos, aos quais as instituições políticas tradicionais sozinhas não são capazes de manejar, as associações tornam-se importantes "soluções" democráticas (i) na superação do individualismo; (ii) na democratização dos instrumentos de representação; e (iii) em uma atuação política mais direcionada à resolução de problemas sociais específicos. Ainda segundo a autora, as associações conferem um rearranjo ao modelo democrático liberal.

Aqui, as associações recebem abrigo no conceito de sociedade civil, e, embora também se ventilem diferenças e divergências quanto ao seu lugar político, são consideradas como atores mais diretamente vinculados aos interesses e problemas da vida social. As associações também seriam responsáveis pela constituição de esferas públicas que problematizam, oxigenam e alteram os mecanismos tradicionais de formulação das regras e políticas que regulam e afetam a vida social (LUCHMANN, 2012, p. 61).

À vista disso, pontua-se que o amadurecimento das relações entre as associações de Picinguaba exigiu um esforço das partes para superar alguns conflitos existentes, dando luz a uma representação mais fortificada e uníssona ${ }^{44}$ direcionada a lutar pelo domínio da Ilha das Couves. Acerca disso, alguns atores comentaram:

Esses atores foram fundamentais em todo o processo com uma participação muito ativa e com muita união. Então, a todo tempo nesse processo em que a gente conquistou, inclusive, como política pública, as normativas da fundação florestal, mas principalmente uma melhoria na qualidade de vida da comunidade e, seja sob o aspecto social, cultural, ambiental, as associações foram fundamentais. As 3 associações sempre

\footnotetext{
${ }^{44}$ É importante pontuar que ainda há discordâncias entre as associações, porém estas se fizeram menores frente a necessidade de se organizar.
} 
trabalhando juntas, ou seja, isso foi uma grande conquista também, porque tinha um histórico de conflito entre os barqueiros e a gente conseguiu superar esse tipo de conflito com as 3 associações trabalhando juntas, assinando juntas todos os ofícios, participando das reuniões (Assessora jurídica - Travessia).

$\mathrm{Eu}$ acho que eles foram os protagonistas desse processo, os maiores interessados e aqueles que tiveram que deixar de lado um pouco de seus conflitos internos pra poder chegar num entendimento mínimo entre eles, e entender que ou eles se acertavam ou eles corriam o risco de todos ficarem sem o acesso à Ilha. Então assim, eu acho que eles tiveram um papel fundamental em se dispor a dialogar e negociar mesmo com todos os conflitos existentes, com todas as diferenças que essas associações têm entre si (Coordenador executivo - LDA).

Contudo, aponta-se que entre os desafios que as associações enfrentaram em 2019 e ainda enfrentam em 2020, diz respeito a alguns barqueiros que não estão salvaguardados em nenhuma associação específica, dificultando a orientação e organização das atividades dentro da figura jurídica. Outra questão colocada, foi a falta de um espaço físico das associações, prejudicando as articulações e a identificação simbólica de um espaço coletivo da comunidade.

Não ter um espaço físico na comunidade é uma dificuldade. Tudo foi vendido, tudo foi doado, tudo foi entregue para as pessoas. A associação não tem uma sede, atrapalha muito pra se reunir, pra dialogar, pra trabalhar mesmo alí com os jovens e adolescentes, pra integrar eles em todo esse processo (Interlocutora 1).

Nesse trecho novamente é possível perceber o efeito da longa ocupação territorial motivada pelo turismo, que hoje reflete-se também na escassez de espaço disponível para a comunidade.

Fórum de Comunidades Tradicionais. O FCT é um movimento social formado em 2007 por caiçaras, indígenas e quilombolas de Angra dos Reis, Paraty e Ubatuba com 
o objetivo de lutar pelo direito ao território, à saúde, à educação, pela valorização da cultura e pelo respeito às tradições e modos de vida. Entre suas frentes de luta, há a Rede Nhandereko, iniciativa que visa promover e conectar roteiros de turismo de base comunitária na região da Costa Verde.

O fórum enquanto movimento social luta em um território específico e em determinados contextos a partir de diferentes identidades coletivas, tendo como meta a implementação da Política Nacional de Desenvolvimento Sustentável dos Povos e Comunidades Tradicionais (PNPCT), instituída pelo Decreto 6.040, de 7 de fevereiro de 2007, que objetiva:

Promover o desenvolvimento sustentável dos Povos e Comunidades Tradicionais, com ênfase no reconhecimento, fortalecimento e garantia dos seus direitos territoriais, sociais, ambientais, econômicos e culturais, com respeito e valorização à sua identidade, suas formas de organização e suas instituições (BRASIL, 2007, Art. 2).

O FCT chega ao território no começo de 2019, quando as associações solicitam a sua contribuição para aprimorar os diálogos com os órgãos públicos e apoiar na construção dos documentos exigidos. Segundo o relatado nas entrevistas, sua atuação permeou e contribuiu nos seguintes aspectos: (a) articulação interna da comunidade; (b) articulação com parceiros para financiamento e auxílio técnico; (c) recuperação e fortalecimento da identificação sociocultural como comunidade tradicional caiçara. A participação do Fórum nesse processo se deu principalmente pela presença intensa e constante de um representante - que também é caiçara de Ubatuba, porém de outra comunidade - no território, acompanhando as reuniões e a execução das novas normas.

Quando a gente procura o MPF, quando a gente viu que ia ficar sem a Ilha, talvez ficassemos de fora do processo, a gente pede socorro pro FCT. E o Fórum como é um movimento muito forte, engajado demais, muito responsável, se compadeceu da luta. E aí então pra construir todo o projeto, precisa de grana, não se faz nada sem dinheiro, esse foi um desespero também nosso e aí vem o FCT com toda aquela bagagem técnica, jurídica e 
conhecimento do movimento de luta. Eles fizeram uma coisa muito legal, que foi empoderar primeiro a comunidade, perguntou o que a gente queria, porque o Fórum não faz sozinho, ele faz com a comunidade (Interlocutora 1).

O Fórum conseguiu desatar um nó lá porque nós, enquanto Estado, tínhamos muitas dificuldades. Veja bem, quando um gestor entra num território com conflito e, por mais que a gente tenha uma metodologia, queira contribuir, os assuntos acabam se misturando. [...] O Fórum veio justamente, não sei se eles têm essa noção, eles desataram um nó que a gente tava patinando, que a gente não conseguia, que era fazer com que a comunidade se empoderasse da situação ali. Tivesse um entendimento do que eles poderiam perder se não se entendessem internamente (Gestora - Núcleo Picinguaba/PESM).

Segundo o relatado nas entrevistas, principalmente pelo coordenador executivo do LDA, o Fórum entendeu a necessidade de atuar nesse caso por duas razões:

Uma porque a comunidade tava demandando, tava tendo uma situação que eles poderiam perder o protagonismo na execução do turismo nessa ilha, e ao mesmo tempo também foi percebido com uma grande oportunidade de mostrar a viabilidade do turismo de base comunitária, de que ele pode sim ser implementado num território de comunidade tradicional que tem essa sobreposição com unidades de conservação; e que as comunidades tem plena capacidade, uma vez que formados, trabalhados esses aspectos de gestão comunitária, eles podem sim exercer a gestão da visitação nesses espaços (Coordenador executivo - LDA).

Conforme Martins e Sansolo (2019), a promoção do protagonismo comunitário, autonomia, equidade e justiça socioambiental, parte de uma visão estratégica do território para identificar potencialidades. Além do TBC, há também o desenvolvimento de iniciativas agroecológicas e educacionais. Em todas as suas dimensões, o FCT é apoiado 
pelo Observatório de Territórios Sustentáveis e Saudáveis da Bocaina, o que os torna quase indissociável. Essa conexão nos leva a outro ator que tornou-se parceiro da comunidade de Picinguaba nesse processo.

Observatório de Territórios Sustentáveis e Saudáveis da Bocaina. O OTSS se origina a partir de uma parceria entre FCT e Fundação Oswaldo Cruz (Fiocruz) como um espaço tecnopolítico para o desenvolvimento de estratégias que foquem em proporcionar o bem viver às comunidades tradicionais. De acordo com o observado em campo, o OTSS entra em Picinguaba com o FCT e passa a contribuir principalmente com a assistência de uma equipe técnica, que envolveu advogado, antropólogo e profissionais da área ambiental.

O território de Picinguaba é um campo de atuação e aplicação de processos metodológicos que o Observatório já tem certa experiência aqui na região da Bocaina. [...] O Observatório se organiza em várias coordenações, e uma delas é ligada a justiça socioambiental, que é justamente a coordenação que lida com questões de conflito fundiário e conflitos de garantia de direitos das comunidades. No fim, Picinguaba é um território de multiaplicação de várias atuações do OTSS, desde de TBC como saneamento e caracterização (Antropóloga - OTSS).

Após o envio da carta por meio de um ofício destinado o MPF, na data de 06 de junho de 2019, as três associações locais com o suporte do FCT e OTSS criaram o "grupo de trabalho de apoio ao TBC da Picinguaba/Ilha das Couves" (Figura 15), apelidado de GT TBC, com a finalidade de centralizar e unificar as tratativas com o MPF e contruir um plano para ordenamento e gestão sustentável da Ilha das Couves, conforme exigido. Esse grupo foi composto por representantes da AMBP, ABPP e ABPTP, além outros moradores de Picinguaba e da família caiçara que ocupa a Ilha (AMBP et al., 2020). 


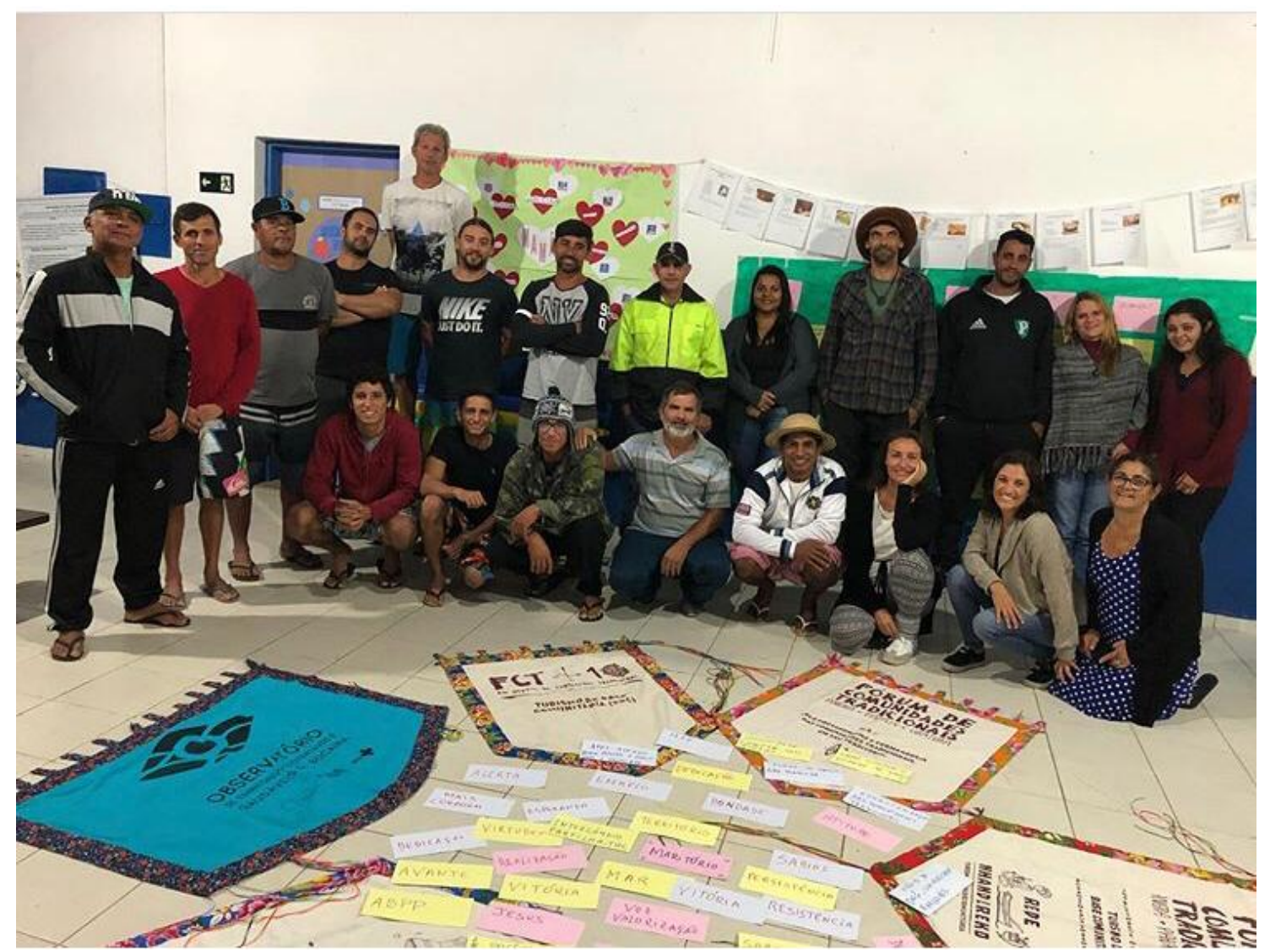

Figura 15. Reunião do GT TBC Picinguaba com representantes da comunidade, FCT e OTSS. Fonte: AMBP et al., (2019)

O GT representou um dos principais instrumentos de articulação dessa trajetória, tornando-se a instância de diálogo e participação para a mediação de conflitos e deliberações. As reuniões do GT se desenvolviam a partir de (i) informes sobre acontecimentos e direcionamentos externos, alguma questão ou instrução do MPF, por exemplo; (ii) esclarecimentos de dúvidas tanto entre a comunidade quanto entre os parceiros, fossem elas mais pontuais ou mais complexas; e (iii) discussões para a deliberação de qualquer tópico que envolvesse o território em relação ao uso turístico, abrangendo sempre a decisão da maioria da comunidade.

Devido a falta de um local para encontro, foi observado que as reuniões ocorriam em três principais lugares: na escola municipal de Picinguaba, na Igreja Adventista e na própria praia de onde saem os passeios para a Ilha. Desde sua instituição até o início de 2020, o GT realizou reuniões com a frequência mínima de duas vezes por semana. Houve também a criação de um grupo no whatsapp com a mesma configuração do GT. 
As reuniões do GT TBC eram frequentadas por diferentes atores que, dependendo do tópico a ser tratado, eram convidados a participar. Esses encontros assumiram uma função de suprir a falta de um espaço que possibilitasse a articulação entre todos os interessados de forma frequente e menos burocrática. Aqui é necessário refletir sobre as limitações do conselho gestor como um espaço anterior ao GT, mas com limitações para cumprir esse papel mesmo contando com a presença das associações de Picinguaba e outros atores que exploram a área. Sobre isso, a assessora jurídica da Travessia comenta:

Durante o período de 2019 e 2020, o conselho do PESM, Núcleo Picinguaba, e o conselho gestor da APA não tiveram nenhuma incidência direta sobre as lutas ou ordenamento da Ilha das Couves. Todo esse processo foi liderado e protagonizado pelo movimento social junto com a comunidade. A participação do sistema ambiental paulista, das unidades de conservação foi uma luta e uma conquista da comunidade e do movimento social.

Moreira (2019) aponta que os conselhos têm como premissa a captação permanente das demandas da sociedade, o que os induz a tornarem instrumentos deficientes em lidar mais profundamente com entraves específicos. Ainda segundo a autora, os conselhos têm se reafirmado enquanto ambiente consultivo, restringindo a cooperação dos participantes ao nível de opinião, consulta ou aconselhamento, sem uma intervenção mais efetiva.

O movimento de criação de uma instância deliberativa da própria comunidade e em seu território, representou a socialização de informações (Figura 16) entre os membros da comunidade, contribuindo para a possibilidade de uma gestão cotidiana do trabalho e para a liberdade de expor seus posicionamentos. Essa ação chama a atenção no sentido em que, de certo modo, surgiu em uma direção contrária à dinâmica hierárquica institucional que, se aplicada, lastrearia o espaço decisório aos limites da Fundação Florestal como órgão gestor da área. 


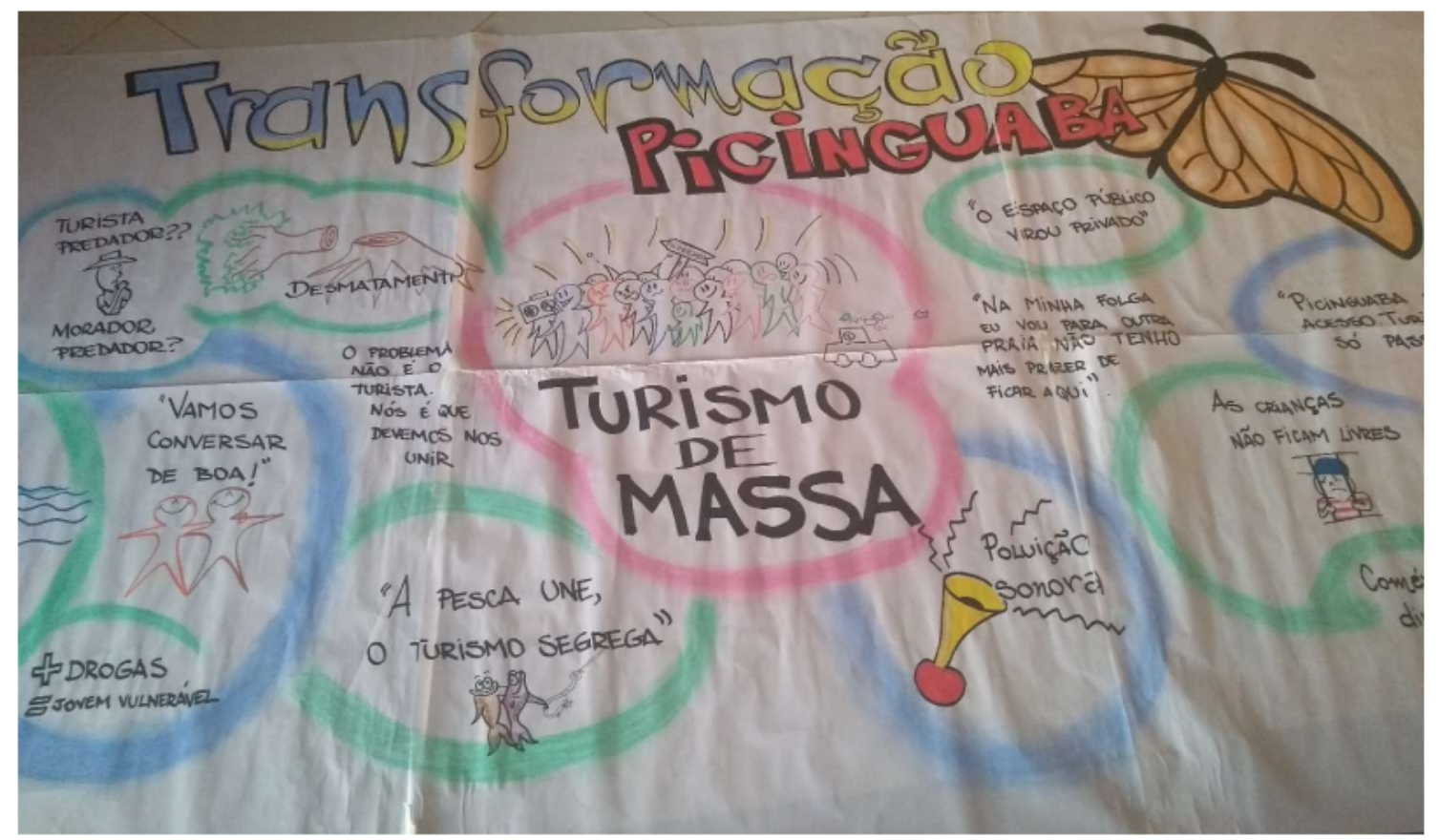

Figura 16. Mapeamento dos efeitos do turismo de massa na comunidade tradicional caiçara de Picinguaba durante uma oficina em setembro de 2019. Fonte: AMBP et al., 2019.

O primeiro e mais significativo ponto de análise sobre o fato do GT ter assumido esse papel, diz respeito à vontade da comunidade em assumir a frente na gestão do próprio território e o apoio do FCT que potencializou a organização interna. Em segundo lugar, observa-se a relevância do respaldo do MPF no levante comunitário e aqui vale retomar a necessidade do capital social de conexão (visto na seção 4.1), como forma de se obter condições jurídicas, políticas e institucionais para fortalecimento do engajamento comunitário. Por último, nota-se que a omissão da Fundação Florestal resultou em lacunas de gestão que, apesar de negativas, fertilizaram o campo para emersão do GT.

Ao mesmo tempo, não é possível desconsiderar que o surgimento do GT se dá em uma conjuntura de intensa pressão à comunidade, que se viu obrigada a lidar com a situação de maneira acelerada. Isso pode ser entendido também como um reflexo da alta responsabilização desferida à comunidade acompanhada de um desencarregamento da FF quanto às suas obrigações. Sobre a falta de responsabilização, outra questão que se coloca é o acompanhamento direto do diretor executivo da Fundação, inclusive em algumas reuniões e negociações, atenuando a participação dos gestores das áreas protegidas em questão. 
Então, a gente sempre defendeu muito que isso [o diálogo entre atores] fosse dentro da APA Marinha, mas isso não aconteceu de fato, isso aconteceu mais recentemente com a criação do Grupo de Gestão Compartilhada da Ilha das Couves [explicado mais adiante], dentro da APA Marinha do litoral norte. Mas toda a construção desse acordo que possibilitou a gestão comunitária do turismo na Ilha das Couves, isso aconteceu com a instituição do GT, que teve a participação direta da diretoria executiva da Fundação Florestal, ou seja, a diretoria executiva da Fundação se apropriou desse assunto de uma maneira que não responsabilizou os gestores das unidades de conservação que estão ali no território pra fazer essa negociação, a diretoria executiva chamou pra si. No LDA, a gente tem uma visão bastante crítica a esse processo, porque pra nós era sempre importante de que esse diálogo ocorresse no âmbito do conselho da APA marinha, porque é o espaço coletivo formalmente instituído. Aquela Ilha está de acordo com o processo de criação da APA, inserida naquela dominialidade ali da APA Marinha e tratar isso direto com a diretoria executiva da Fundação Florestal não era positivo pra um processo de construção participativa de envolvimento dos atores interessados na gestão desse território (Coordenador executivo LDA).

De maneira geral, a comunidade e parceiros avaliaram a participação dos gestores de forma segmentada, sendo relatado uma participação mais ativa do gestor da APA e menos da gestora do Núcleo Picinguaba. Entre os argumentos, dois foram citados com mais frequência: primeiro, o fato da Ilha das Couves ser o alvo central do processo de ordenamento, o que faz com que o assunto esteja em maior dominialidade da APAMLN; segundo, o fato de que o PESM possui um longo histórico de conflitos com a comunidade, muito devido ao seu caráter de proteção integral, o que faz com que os assuntos se misturem quando há o envolvimento do núcleo. 
Como citado, a formação do GT teve também o desígnio de construir o plano e cumprir com as condicionantes colocadas pelo MPF. Esse processo, de acordo com o relatado pelo representante do FCT, demandou a contratação de profissionais que auxiliassem exclusivamente a comunidade de Picinguaba, devido ao pouco tempo hábil e a complexidade do cenário. Então, ainda no primeiro semestre de 2019, o Fórum traz mais dois parceiros que supriram diferentes brechas na articulação.

Travessia Consultoria e Projetos Sustentáveis. A Travessia é uma empresa individual de assessoria que desde 2014 vem atuando com foco em projetos relacionados ao meio ambiente, direito às cidades sustentáveis, planejamento e gestão territorial para a defesa de direitos e assessoria junto aos povos e comunidades tradicionais. Antes de integrar a equipe do TBC Picinguaba, a empresa já havia realizado outros trabalhos em parceria com o Fórum e OTSS para a defesa de comunidades em situação de conflito com unidades de conservação.

A chegada da empresa ao território se deu inicialmente por meio de duas profissionais, uma assessoria jurídica popular e outra em turismo de base comunitária, que passaram a acompanhar diariamente o caso da Ilha das Couves. O trabalho proposto ocupou duas frentes: uma mais externa, para diálogos e negociações diretas com o MPF, FF, Prefeitura e outros atores, que ficou sob responsabilidade da assessora jurídica; outra interna, com uma assistência frequente dentro de Picinguaba, tentando buscar e manter a coesão entre os membros de forma a possibilitar a construção factual do TBC. Entretanto, apesar de existir essa divisão entre as atuações, a assessora turística aponta que

O processo de coesão da comunidade era tão delicado que toda a equipe foi necessária para apoiar. [...] Todo mundo trabalhou nas duas frentes porque era muito trabalho de fato para pouco tempo.

É relevante ressaltar que dentre os atores mapeados, a Travessia é entendida como um dos mais importantes, devido a intensidade da sua participação, que envolveu em desempenho diário e em todas as dimensões da questão.

A contratação das profissionais foi possível através da construção de um projeto, realizado pelo Fórum e OTSS, para a captação de recurso com outro significante ator dessa trajetória, o Instituto Linha d'Água. Contudo, faz-se necessário colocar que o 
envolvimento da assessora jurídica foi anterior a aprovação do projeto, considerando que já estava se aproximando a partir da sua militância como colaboradora voluntária.

Instituto Linha d'Água. Instituto e FCT possuem uma relação que vem se construindo desde 2016, quando o LDA amplia seu interesse pelo o tema do uso público em áreas protegidas costeiras e marinhas, devido a percepção da vontade do estado de São Paulo em adotar a concessão de serviços à iniciativa privada como principal estratégia para promover a visitação em APs. Destaca-se que nesse período a Lei 16.260 estava sendo aprovada pelo governo do estado. Essa lei, já citada em outra seção, representou o mais relevante movimento rumo à concessão de UCs estaduais, prevendo a concessão de pelo menos 25 áreas.

O Instituto atua por meio de quatro principais programas: pesca responsável, com o objetivo contribuir com a qualidade e a sustentabilidade de territórios pesqueiros tradicionais; áreas marinhas protegidas, que envolve o fortalecimento da gestão e aumento da representatividade nesses espaços; conservação de tubarões e raias, com foco na conservação de elasmobrânquios; e negócios associados à conservação, com a finalidade de apoiar empreendimentos com potencialidade de fornecer rendas alternativas às comunidades locais.

Em 2017 o Instituto realizou uma extensa pesquisa de levantamento dos arranjos locais para o uso público em áreas protegidas costeiras e marinhas do Brasil. O estudo, cujo relatório técnico foi publicado em 2018, possibilitou um detalhamento das realidades dos usos que estão sendo desenvolvidos, de modo a fundamentar delineamento e ações futuras. O trabalho também abrangeu os instrumentos que estão sendo utilizados na oficialização desses arranjos.

Especificamente no contexto territorial de Picinguaba, a sua principal contribuição veio com o financiamento da equipe da Travessia. Todavia, conforme relata o coordenador executivo do LDA, houve também, anteriormente a contratação das assessoras, um apoio estratégico ao FCT e OTSS para tentar dimensionar o que seria necessário para que o TBC fosse concretizado e garantido no território. A partir disso, foi entendido que seria necessário para atender a demanda, uma pessoa especializada em TBC e outra em articulação política, jurídica e institucional. 
Essa foi outra parceria fundamental, e tem sido ainda pra outras questões que o fórum atua. A gente precisou de um financiamento pra projeto, desde a parte mais simples como faixas até a contratação de profissionais da Travessia e de um projeto formal, embora tenha sido a gente que elaborou, mas enviamos para o Linha D’Água e ele aprovou e veio uma verba. [...] O Instituto Linha D'Água foi fundamental. Ele não tem muita burocracia, porque às vezes tem institutos, ONGs, edital que tem muita burocracia, sem tempo hábil, eles não tem um tempo de edital certo. Você vai conversando e, se eles aprovarem, encaminha verba. Então, nesse sentido o Linha D’Água foi fundamental pra poder substanciar esse primeiro momento, o projeto mesmo completo (Representante caiçara - FCT).

A formação dessas parcerias permitiu refinar o movimento para a construção do plano de ordenamento, considerando que o GT TBC passou a agir com o amparo técnico e político. Esse processo, segundo os entrevistados, teve caráter formativo no sentido em que a partir de uma construção coletiva proporcionou o empoderamento comunitário.

Pela primeira vez a comunidade foi incluída no planejamento, nas tomadas de decisão sobre o seu território. Então, o plano no manejo [das UCs presentes no local] foi feito lá, tinha umas câmaras técnicas, uns espaços participativos, mas foi muito insatisfatório, não foi de fato participativo. Eu acho que na hora que a comunidade se reúne para incluir um documento seu, a partir do seu olhar, você inaugura aí um protagonismo e é inédito. Esse processo da Ilha das Couves é inédito com relação a isso. Pela primeira vez as associações comunitárias entenderam o que é ser protagonista de um processo de gestão territorial. E que eles não são obrigados a receber de cima pra baixo tudo o que é imposto pelo Estado (Antropóloga - OTSS).

Entre junho e setembro de 2019 houve uma intensa atividade na comunidade para conseguir que o plano fosse entregue no prazo estipulado pelo MPF. Esse período é 
acompanhado por uma acentuada participação das mulheres da comunidade, que por diversas vezes assumiram posições formais e não formais de liderança, nas inúmeras reuniões de preparação do documento.

No começo só tinham algumas mulheres e poucos homens. [...] Quando o Ministério Público deu um prazo pra gente entregar, foi muito rápido. Então, a gente escreveu, na verdade quem escreveu foram as meninas né, a gente jogava as ideias, dizendo o que era melhor e elas foram escrevendo. Foram poucas pessoas, porque tiveram muitas reuniões pra escrever o projeto e cada vez ia menos gente (Interlocutora 3).

A interlocutora 3 conclui esse trecho da entrevista listando os caiçara que sempre estavam presentes nas reuniões. De acordo com ela, eram cerca de 4 mulheres e 1 homem.

Sobre a exigência de um plano que exige maior complexidade para a confecção, houve um destaque em relação a sua importância para a definição e compartilhamento das responsabilidades entre os atores, evitando uma sobrecarga de funções à comunidade. Segundo a Procuradora, foi solicitado um posicionamento mais formal da comunidade que abordasse (i) as ações previstas para a gestão do turismo; (ii) a atribuição e participação de cada ator no ordenamento e desenvolvimento turístico; (iii) a identificação dos aspectos a serem ajustados ou regrados; e (iv) a garantia de cumprimento do limite previsto no estudo CCT.

Apesar da importância como instrumento de planejamento e gestão, a necessidade de um plano para a garantia do protagonismo comunitário levanta uma questão sobre a habilidade da comunidade em conceber e se apropriar desse conteúdo.

Por outro lado, um plano escrito, aprovado, ele é um material de certa forma técnico-científico, então eu ainda acho que há uma necessidade de maior apropriação sobre esse conteúdo, sobre a perspectiva de continuidade do que tá definido ali pelas próprias comunidades. Porque o que a gente tem evidenciado é que o plano ficou muito bom, foi aprovado, em alguma medida ele está sendo implementado, mas quem que está zelando por isso? Quem que 
tá olhando pra isso e vendo quais elementos estão faltando, o que precisaria ter continuidade? Eu não vejo ninguém exercendo esse papel hoje. E pras comunidades que têm essa questão sobre apropriação de um conteúdo escrito, de manter essa capacidade de monitoramento, de metas e coisas previstas, eu acho que ainda tem um trabalho grande de continuidade do processo formativo pra que a comunidade possa se apropriar cada vez mais desse instrumento e requerer a continuidade dele ou o aprimoramento dele ao longo do tempo (Coordenador executivo - LDA).

Acerca da fragilidade relacional entre documento e comunidade, dois pontos foram observados: houve relato de uma baixa participação quantitativa nas reuniões de construção e em uma entrevista específica, não houve reconhecimento por parte de um caiçara sobre do que se tratava o plano; há uma preocupação da própria comunidade e dos parceiros sobre a autonomia dos comunitários em prosseguirem com o plano sem um apoio mais ativo.

A estruturação do plano, nomeado de "Plano de ordenamento e gestão comunitária para o uso público sustentável da Ilha das Couves do território tradicional caiçara de Picinguaba", se deu a partir dos seguintes itens: (i) breve caracterização da comunidade caiçara de Picinguaba; (ii) histórico e relevância da proposta; (iii) diagnóstico comunitário dos conflitos provocados pelo turismo de massa predatório; (iv) plano de trabalho de ordenamento turísticos e apoio ao turismo de base comunitária da Picinguaba: metas, diretrizes, ações e responsáveis; (v) ordenamento territorial como condição para a gestão sustentável: ações governamentais emergenciais de apoio ao TBC e (vi) proposta de cronograma de trabalho.

A autoria do documento é assinada pelas três associações locais e apoiada pelo FCT, Rede Nhandereko e OTSS. É possível acessar sua capa pelo Anexo III. O plano foi lançado em 16 de setembro de 2019 e entregue ao MPF no mesmo mês. Entre suas metas (AMBP et al., 2019, não paginado), estão:

1. Fortalecimento da organização comunitária caiçara de Picinguaba, com foco nas relações sociais que compõe o modo de vida caiçara e os usos múltiplos do território, em apoio ao 
desenvolvimento do Turismo de Base Comunitária e uso público sustentável da Ilha das Couves;

2. Defesa do território tradicional da comunidade de Picinguaba frente à política de privatização do patrimônio público e conflitos de sobreposição com unidades de conservação da natureza;

3. Proposta de arranjo de ordenamento e gestão territorial comunitária para o uso público sustentável que compatibilize os direitos e deveres dos povos e comunidades tradicionais e as finalidades de unidades de conservação da natureza marinha e terrestre, articulando a dimensão histórica e cultural do território de forma integrada ambiental e econômica.

Seu conteúdo possibilitou o preenchimento de algumas lacunas essenciais para a melhor compreensão dos conflitos que permeiam o território. Foi construída uma matriz com os conflitos identificados em oito âmbitos: organização comunitária, ordenamento da venda de passeios turísticos, fiscalização, ordenamento do estacionamento e áreas de embarque/desembarque turístico, turismo predatório, serviços públicos, infraestrutura básica, e comunicação e educação socioambiental. Além disso, houve um levantamento sobre o trade turístico que explora a Ilha, envolvendo os nomes, locais de venda e tipo de transporte das agências turísticas.

Outro esforço relevante direcionado à resolução do cenário de superexploração, se deu por meio da identificação de outros atrativos no território que possibilitariam construir um roteiro mais amplo abrangendo a valorização do modo de vida caiçara e a mitigação da pressão exercida sobre a Ilha das Couves. Entre os atrativos, estão presentes momentos para a contação de histórias com griôs ${ }^{45}$ caiçaras, feituras de redes e canoas, visitas ao cerco, festejos caiçaras e corridas de canoas.

\footnotetext{
${ }^{45}$ Griô é um termo usado entre os caiçaras para se referir aos mais velhos.
} 
Entretanto, é importante pontuar que a proposição de outros roteiros que vão ao encontro dos princípios do TBC não foram ainda concretizados, mas contribuem para perspectivas futuras. Sobre isso, o próprio plano comenta:

[...] o desenvolvimento do Turismo de Base Comunitária é um processo temporal, histórico e político de organização social coletiva e de defesa do território. O que exige respeitar os tempos dos sujeitos e corpo coletivo da comunidade de Picinguaba, ou seja, é um processo de longo prazo que será implementado em etapas, objetivando-se avanços na gestão comunitária turística a cada ano (AMBP et al., 2019, não paginado).

Após a construção teórica do plano, foi dado início a sua consolidação prática que se desenvolveu pelos meses de outubro, novembro e dezembro de 2019. As principais ações realizadas durante esse período podem ser vistas na Figura 17. É importante esclarecer que algumas dessas ações não foram previstas de maneira específica pelo plano e sim foram construídas a medida em que os atores se articulavam, principalmente entre setembro e dezembro de 2019. Mesmo assim, elas foram abrangidas pelo documento de certa maneira a partir da definição de objetivos mais amplos, que foram posteriormente alcançados por essas atividades mais precisas. 
- Cadastramento dos barqueiros de Picinguaba para a alta temporada;

- Regularização das embarcações e habilitações;

- Ordenamento do trânsito de embarcações através da instalação de raias e boias;

- Instituição de um ponto único de vendas em Picinguaba;

- Construção de um receptivo turístico na Ilha das Couves;

- Padronização do valor do passeio;

- Estruturação de turnos de visitação;

- Fiscalização;

- Criação e gestão do fundo comum do TBC;

- Criação de um número e e-mail coletivo para agendamento de passeios;

- Comunicação socioambiental;

- Ordenamento do trânsito de ônibus turísticos.

Figura 17. Atividades realizadas para o ordenamento turístico no território tradicional caiçara de Picinguaba. Fonte : AMBP et al., 2019.

Essas ações foram colocadas em prática principalmente pelas mãos dos caiçaras. O cadastramento dos barqueiros foi realizado com a organização de um mutirão que contou com a presença majoritária do GT e equipe FCT/OTSS/Travessia. Essa ação possibilitou a criação de uma lista, que foi utilizada durante a alta temporada para organizar o revezamento dos barqueiros na realização das travessias. As raias e boias foram arranjadas, pintadas e instaladas (Anexo IV) pelos barqueiros com o uso de seus próprios $\operatorname{barcos}^{46}$. Do mesmo modo, o receptivo e ponto único (Figura 18) foram levantados por meio de uma força-tarefa caiçara.

A criação de um fundo comunitário do turismo foi possibilitado pela centralização da venda dos passeios e padronização do valor. No preço da travessia até a Ilha foi embutido uma porcentagem destinada ao fundo coletivo, para possíveis aprimoramentos na infraestrutura local, idas a reuniões externas ao território e etc. A criação de uma central de vendas também foi de extrema relevância à medida que, além de distribuir

\footnotetext{
${ }^{46}$ A regularização das raias e boias na Ilha das Couves foi feita pela Autorização Emergencial da Secretaria Municipal de Meio Ambiente n 04, de 27 de dezembro de 2019, válida durante o verão de 2020. O pedido para a regularização foi protocolado pela AMBP em nome do GT TBC Picinguaba.
} 
igualmente a renda entre os barqueiros, abrigou inúmeras mulheres que antes tinham que ir à estrada vender passeios.

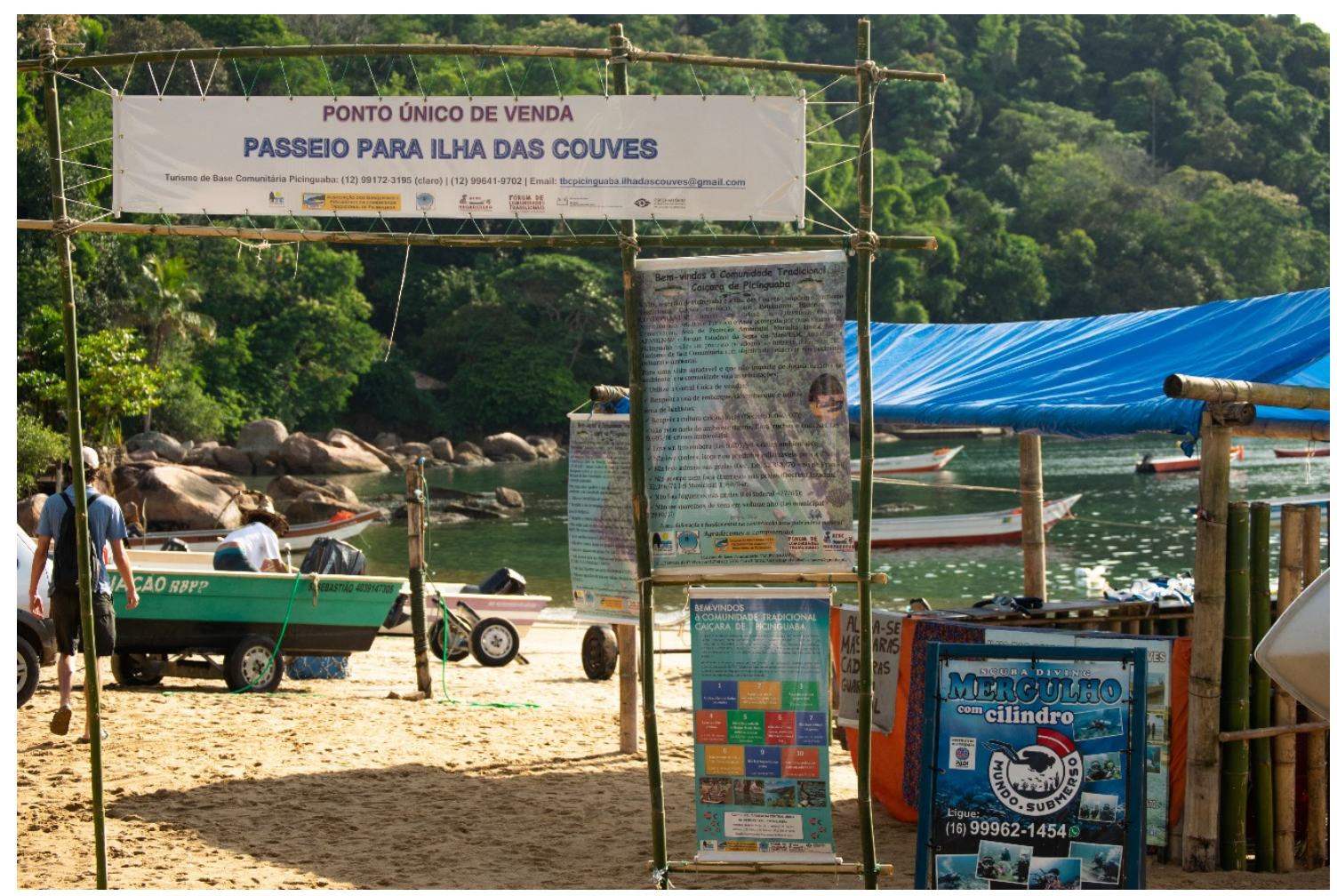

Figura 18. Ponto único de vendas estruturado pelos próprios caiçaras em 2019. Foto: Giovana Cioffi.

A fiscalização foi realizada mediante uma contribuição entre associações e Fundação Florestal. O órgão disponibilizou para a alta temporada um monitor ambiental e um guarda terceirizado que eram levados pelos caiçaras à Ilha das Couves para realizar a vigilância contra possíveis descumprimentos e informar os turistas sobre as regras e atrativos. Além da comunidade e FF, houve um escasso apoio da Marinha na fiscalização, o que foi entendido como problemático pelos atores de fora do setor público pois, segundo eles, facilitava a presença de embarcações com algum tipo de irregularidade.

[...] A Marinha não foi eficiente na questão da fiscalização, mas fez o seu papel de formalizar/regularizar os barqueiros com as suas carteiras. A Marinha é um pouco ausente, muitas vezes não vem quando é acionada. Ou quando vem, não autua os infratores. Isso é ruim porque encoraja a informalidade e a irregularidade. $\mathrm{E}$ se tem muita gente irregular seja na embarcação, na quantidade 
de passageiros ou na habilitação, o coletivo todo do TBC está em risco (Antropóloga - OTSS).

Sobre o ordenamento do trânsito, foi relatado que não houve apoio do Núcleo Picinguaba ou da prefeitura para que a comunidade conseguisse limitar a quantidade de ônibus no território. De acordo com a assessora de turismo da Travessia, houve uma reunião entre GT, prefeitura e gestora do núcleo, na qual foi formalmente combinado que a entrada de ônibus seria permitido apenas mediante agendamento. Essa questão, segundo a assessora jurídica, representou uma das poucas contribuições da gestão do núcleo.

Em relação ao Núcleo Picinguaba do Parque Estadual da Serra do Mar a relação é bem diferente, e a participação foi, assim, bastante residual. Acho que a única questão que a gente conseguiu, tentou avançar, foi o controle terrestre, do acesso dos ônibus e excursões terrestres (Assessora jurídica - Travessia).

Acerca desse tópico, a gestora do Núcleo Picinguaba comentou que houve uma contribuição "forçada" da prefeitura, após uma solicitação mais contundente de sua parte. Já sobre a colaboração do Parque, foi citado que:

Eu acho que também um auxílio do poder público é muito limitado na legislação. [...] Às vezes o pleito deles, por exemplo, "a gente não quer que entre ônibus, o parque tem que fazer alguma coisa". A gente não tem instrumento legal para fazer isso. O município tem uma legislação municipal de cobrança de taxa, eles que fornecem a senha pra entrada dessas agências de turismo aqui. Então eu acho que esse apoio do poder público é muito difícil também, complicado.

O plano de manejo do PESM prevê que em Zonas de Uso Intensivo - zonas que possuem visitação pública, parte urbana ou ocupação tradicional, e que abrigam parte do núcleo Picinguaba - é permitido a circulação de veículo para transporte individual ou coletivo com fins de visitação desde que estes sejam autorizados pelo órgão gestor e respeitem a capacidade de suporte e os limites definidos por cada núcleo (SÃO PAULO, 2008). 
Ainda sobre as atividades listadas na Figura 17, a comunicação socioambiental se deu por meio da confecção de placas que abordavam informações sobre as características ambientais e culturais do território, e recomendações e diretrizes que visavam o mínimo impacto. Além disso, houve também a produção de guia de visitação educativo possibilitado a partir da minha contratação e entrada no território, como explicado na seção 5.1.

A estruturação dos turnos de visitação (Figura 19) não foi especificada no POGC, porém representou uma das medidas mais importantes no processo de ordenamento comunitário do turismo, tornando o limite máximo de 177 pessoas aplicável sem que fosse necessário que muitos barqueiros deixassem de trabalhar por dia. Isso porque, de acordo com o POGC, são 38 barqueiros de Picinguaba que trabalham com passeios à Ilha, portanto se não houvesse turnos de visitação, não teriam um volume de turistas suficiente para que todos fizessem a travessia no dia.

\section{TURNOS DE VISITAÇÃO NA ILHA DAS COUVES}

1. 8 às $11 \mathrm{~h}$ - passeios realizados somente pela comunidade de Picinguaba;

2. 11 às $14 \mathrm{~h}$ - passeios realizados somente pela comunidade de Picinguaba;

3. 14 às $17 \mathrm{~h}$ - passeios realizados somente pelos parceiros do TBC Picinguaba.

Figura 19. Divisão dos turnos de visitação na Ilha das Couves versão temporada 2019/2020.

O terceiro turno, conforme estipulado pelo plano de ordenamento, se destinou à Associação de Pescadores e Barqueiros da Praia do Estaleiro, Associação de Moradores da Almada e Associação de Turismo Náutico de Ubatuba (ATNU). Levando em conta a alta presença das agências de turismo da região central de Ubatuba no período entre 2016 e 2018, a ATNU se tornou um importante parceiro para o respeito ao ordenamento proposto pela comunidade.

Associação de Turismo Náutico de Ubatuba. A ATNU é uma organização da sociedade civil criada em 2016 com o objetivo centralizar a atuação dos empresários do setor de turismo de navegação. Segundo seu vice-presidente, a associação vem tentando contribuir para o desenvolvimento mais responsável desse tipo de turismo por meio de 
ações relacionadas ao regramento de embarcações, profissionais e habilitações. Ainda consoante à ele, a organização conta com 16 associados.

De acordo com os entrevistados da comunidade e parceiros, a ATNU apoiou a iniciativa comunitária e acatou as novas diretrizes de uso, tendo participado inclusive de algumas reuniões do GT TBC. Entretanto, foi destacado que como a associação não envolve todos os operadores, houve um desrespeito de agentes independentes em relação ao regramento comunitário. Segundo o presidente da ABPTP, uma das dificuldades com as agências turísticas é a desconsideração da porcentagem destinada ao fundo do TBC, que muitas vezes não é repassada à comunidade.

A ATNU é apoiadora da Picinguaba. Só que ela não envolve todos os operadores de turismo náutico. Ninguém é obrigado a se associar. Assim como ninguém é obrigado a se sindicalizar, mais ou menos nesses termos. Mas ela tem sido uma grande parceira, junto com as outras comunidades do entorno da ilha. Já muitas operadoras do centro de Ubatuba fazem jogo contra. Vão na reunião engolem a obrigatoriedade da coisa toda, mas tenta burlar o sistema. Se não tiver guarda avisa que vai outra escuna (Representante caiçara - FCT).

[...] a Associação de Turismo Náutico de Ubatuba, justamente, tinha uma posição a favor do ordenamento dessa visitação e se tornaram mais próximos e mais parceiros pelo próprio interesse em ordenar a atividade. Atividade à qual eles também eram prejudicados à medida que no verão entrava um monte de gente [operadores turísticos] que não tinha o cuidado com o território, de estar organizado mesmo, de estabelecer acordos interessantes, e que talvez tivessem orientados pelo ganho desesperado de dinheiro. Isso [ordenamento] favoreceu algumas empresas que queriam organização (Assessora de TBC - Travessia).

A inserção das agências de turismo náutico na divisão dos turnos foi promovida também devido a uma obrigatoriedade imposta pela FF. 
A gente trouxe muita transparência nas nossas posições, de falar “desse jeito vai rolar, desse jeito não vai rolar, vocês escolhem". Não por uma imposição, mas sobre o que é possível de ser feito. O fato de ter repartido com o trade turístico foi importante, isso era essencial pra nós (Diretor executivo - FF).

Ainda segundo ele, impedir o envolvimento deste setor traria fragilidade à proposta, considerando que não há dados oficiais de tradicionalidade da Ilha das Couves que garantissem uma ação do Estado direcionada ao uso exclusivo comunitário e que há uma complexidade maior por a área estar submetida ao domínio de diferentes segmentos públicos. Observa-se sobre essa questão dois pontos: como foi apontado na seção 1.4, a Ilha compõe o patrimônio histórico cultural de Picinguaba; e há novamente uma discordância entre o discurso do MPF e FF sobre a viabilidade de implementar a exclusividade ou não.

A exigência foi assumida pelas associações locais e aplicada na estruturação dos turnos, entretanto, durante a realização das entrevistas e participação em reuniões do GT, foram observados momentos de desconforto quanto a imposição, onde falas caiçaras reforçando a relação entre Picinguaba e Ilha foram empregadas.

De tudo que a gente apresentou enquanto parceria da comunidade, na construção do projeto em si, a Fundação vem e fala "não dá pra gente apoiar só Picinguaba, a Ilha das Couves não é explorada só por vocês", Aí a visão do Estado né, não dá pra beneficiar só uma comunidade. Poxa, a Ilha das Couves é patrimônio histórico cultural, a ligação da comunidade é muito forte com ela, pesca e agricultura também. E como é que o Estado fala isso? [...] A fundação meio nos força a dialogar com quem também explorava o turismo da Ilha (Interlocutora 1).

A proposta para a operação dos três turnos foi aplicada durante a alta temporada 2019/2020, entre dezembro e março. No dia 21 de novembro de 2019, as associações locais em conjunto com a ATNU e outras associações comunitárias enviaram ao MPF, SPU, Marinha, Prefeitura e FF, uma proposta de regramento visando principalmente a 
normatização dos turnos. Após algumas negociações, a portaria $n^{\circ} 315$ foi aprovada em 26 de dezembro de 2019 pela Fundação Florestal/Diretoria Executiva.

Conceitualmente, portaria é um documento de ato administrativo que pode ser assinado por qualquer autoridade pública, referente à aplicação de recomendações, leis ou regulamentos, normas de execução de serviços, punições, demissões ou outra determinação de sua competência. Segundo o gestor da APAMLN, a implementação de novas regras por meio de portaria, por seu caráter temporário, permite que durante o processo seja possível avaliar e revisar o que for necessário, fato que não seria possível se algum mecanismo mais perene, como o TAUS ${ }^{47}$, fosse adotado.

De acordo com Machado (2010), a portaria regulamentar envolve uma pontualidade que vai além da sua característica provisória. Diz respeito também a possibilidade de garantir normas elaboradas caso a caso, ou seja, de acordo com o contexto territorial específico a que se deseja aplicá-la. Esse fato contribui para que ações estratégicas e setoriais relacionadas à promoção turística em determinado território sejam empregadas com maior facilidade para o ordenamento do turismo.

Além de dispor sobre o limite estabelecido pelo o estudo CCT e sobre os turnos, a portaria instituiu também (a) o dever da comunidade em realizar a demarcação marítima e o controle dos resíduos sólidos; (b) a alocação de um posto de vigilância e de monitoria ambiental pela FF; (c) o cadastramento de operadores; e (d) a constituição de um Grupo Emergencial de Gestão Compartilhada com representantes da comunidade de Picinguaba, Estaleiro, Almada e Ubatumirim, dos operadores de escunas e lanchas, e da prefeitura, para contribuir com a fiscalização e ações conjuntas de ordenamento.

Algumas ações previstas na portaria já haviam sido antecipadas pelo plano e/ou realizadas, como a demarcação marítima com raias e boias, o cadastramento dos operadores ou a questão dos resíduos sólidos, que foi incluída nos materiais de

\footnotetext{
${ }^{47}$ Segundo a Procuradora da República, há o interesse de sua parte e da comunidade que esse cenário evolua para o TAUS, inclusive conforme seu relato, já foi instaurado um procedimento para a concessão do TAUS referente a vila de Picinguaba, Ilha das Couves e todo o espelho d'água da área para as associações locais. Contudo, esse assunto não foi comentado por nenhum outro interlocutor.
} 
comunicação socioambiental visando a diminuição de lixo trazido e produzido pelos visitantes. A portaria foi publicada com o prazo de três meses, vencendo em março de 2020 .

A publicação dessa portaria, pelo o que foi observado em campo e nas entrevistas, possui significados que permeiam dimensões concretas e simbólicas. Concretamente, a portaria tornou oficiais as diretrizes propostas pela comunidade, fazendo com que o desrespeito à elas pudessem resultar em sanções penais. Simbolicamente, o movimento representou uma autenticação do protagonismo caiçara, assumindo então uma posição de decisores dos rumos do próprio território. Houve também menção à portaria como forma de garantir um comprometimento mais efetivo da Fundação Florestal.

Nesse processo, além de ações práticas e específicas, houve um esforço em potencializar a identificação sociocultural dentro da comunidade, como já foi apontado em relação ao papel do FCT. Nesse sentido, nos meses de novembro e dezembro foram promovidas trocas entre Picinguaba e outras comunidades que estavam envolvidas com a Rede Nhandereko, com intuito de possibilitar um maior entendimento sobre conceitos e ações que permeiam o desenvolvimento do TBC. Entre essas experiências, houve uma visita com a comunidade de Picinguaba ao território caiçara tradicional de Trindade $^{48}$, onde puderam vivenciar práticas do $\mathrm{TBC}$, como a partilha do dinheiro entre os caiçaras fruto da atividade turística.

Passada a alta temporada, em maio de 2020 uma nova versão do POGC foi lançada, compreendendo, além dos itens da versão 2019 listados acima, uma terceira parte composta por um conteúdo relacionado a implementação do POGC em 2019/2020, onde as reuniões, ações realizadas e documentações associadas estão relatadas com maior precisão e detalhamento.

É importante pontuar que em abril de 2020 foi finalizado o período de contratação da empresa Travessia. Com isso, não houve o prolongamento da assessoria frequente e intensiva no território. Contudo, devido a pandemia COVID-19, entre abril e meados de

\footnotetext{
${ }^{48}$ A comunidade tradicional caiçara de Trindade se localiza no município de Paraty, na vila de Trindade, e vem desenvolvendo o TBC com o apoio do FCT. A área conta com duas associações, a Associação de Moradores de Trindade (AMOT) e a Associação de Barqueiros de Trindade (ABAT).
} 
outubro de 2020 a área permaneceu fechada para turismo. Mesmo assim, as articulações prosseguiram através do grupo de whatsapp do GT TBC. A partir disso, em 24 de setembro de 2020, as mesmas associações que assinaram a antiga portaria direcionaram à Fundação Florestal uma proposta conjunta de nova normativa a ser aplicada no verão 2020/2021. Então, no dia 5 de outubro de 2020, a portaria $n^{\circ} 323$ foi publicada pela FF, com validade até 31 de março de 2021. Na Figura 20 é possível ver o que da proposta coletiva foi aceito e o que foi negado pela FF.

\begin{tabular}{|l|l|l|}
\hline \multicolumn{2}{|c|}{ PORTARIA 323/2020 } \\
\hline & • & Aprimoramento dos turnos de visitação; \\
& • & Reconhecimento das associações de Picinguaba \\
& como gestoras dos turnos; \\
Aprovado pela FF & Vinculação do Grupo de Gestão Compartilhada ao \\
& conselho gestor da APAMLN; \\
& Suspensão de 30 dias ou descredenciamento como \\
& penalidade para operadores que descumprirem as \\
& regras; \\
- & Previsão de aumento da capacidade de suporte, caso \\
implantado saneamento e monitoria ambiental.
\end{tabular}




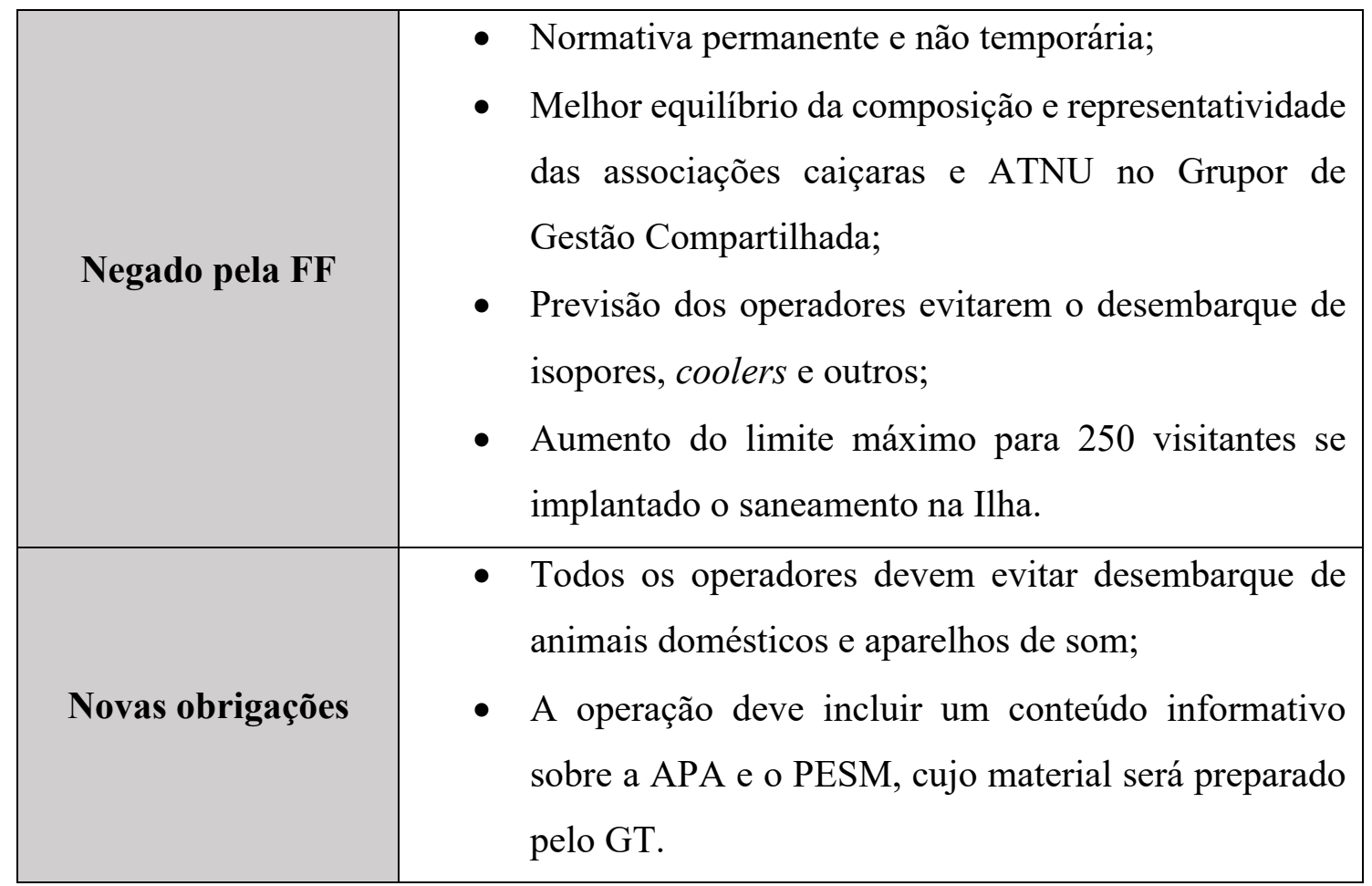

Figura 20. Relação das principais aprovações e negativas da FF em relação à proposta conjunta de nova normativa para a alta temporada $2020 / 2021$.

A estruturação do turno proposta para a alta temporada 2020/2021 sofreu algumas mudanças, as mais relevantes foram: o horário do primeiro turno passou a ser das 8 às 12 horas, e o primeiro e segundo turno passaram a abranger também operadores do setor de turismo náutico. Essas alterações remetem a duas questões principais: ao descontentamento quanto ao horário anterior ser ruim ou não ser suficiente para realizar o passeio com os turistas, devido a distância, horários dos roteiros, entre outros; e ao conflito interno entre a comunidade e a família caiçara que ocupa a Ilha, devido a brusca queda de rendimento do seu restaurante nesse processo.

A questão do faturamento do restaurante da Ilha tem sido um dos principais pontos de conflitos na gestão comunitária do turismo. Segundo as interlocutoras 2 e 3 , que fazem parte desta família, o novo regramento afetou de forma negativa o nível do consumo no local, prejudicando a vida financeira de todos os membros da família e outros ajudantes que dependem dessa verba. Por meio de suas falas e da vivência em campo, foi possível observar alguns pontos que para elas são os mais críticos nessa situação:

○ A limitação máxima de 177 pessoas, que reduziu a visitação em cerca de 90\%; 
○ A estruturação dos turnos, que diminuiu o tempo da visitação para três ou quatro horas. Antigamente, o mesmo turista chegava na Ilha cedo e ia embora ao final da tarde, tendo maior tempo hábil para almoçar ou lanchar;

- A falta de proibição de coolers e isopores, o que, se proibido, evitaria que os visitantes levassem sua própria comida e bebida, estimulando o consumo do restaurante da família. Sobre isso, elas apontam que, além da falta de contribuição da FF para aprovar a proibição (Figura 20), não há a colaboração dos barqueiros para informar e incentivar o turista a consumir ou solicitar que os coolers não sejam levados.

Em relação ao Grupos de Gestão Compartilhada, como foi apontado, sua criação se deu pela portaria de 2019. Naquele momento, esse grupo se constituiu em uma instância diferente à do GT TBC, representando um movimento de deslocamento da centralidade das negociações para o âmbito legal da Fundação Florestal. Contudo, esse movimento ocorreu de maneira apartada aos campos de participação das unidades de conservação locais, fato que foi revertido na última portaria a pedido da comunidade e parceiros.

[...] a partir da normativa foi criada uma instância, que foi um grupo de trabalho emergencial sobre a Ilha das Couves de forma separada dessas instâncias de participação das unidades de conservação. E uma das nossas lutas, digo do fórum, das associações da Picinguaba, da assessoria, foi que esse grupo que tava solto fosse articulado ao conselho gestor da APA Marinha, de forma que fosse consolidada uma instância de gestão participativa na estrutura administrativa do estado, e isso a gente só consegue na segunda portaria, nessa última agora do verão 2020 e 2021 (Assessora jurídica - Travessia).

A incorporação desse grupo ao conselho representou um avanço à legalidade do processo de gestão comunitária, à medida que oficializou um espaço decisório que abrange a comunidade dentro do conselho responsável por direcionar os rumos da parte marinha e insular do território de Picinguaba. Destaca-se que na composição desse grupo há uma vaga para a comunidade, que está sendo ocupada por uma mulher. De acordo com a assessora jurídica, apesar desse avanço, a gestão efetivamente compartilhada ainda é um 
desafio o qual exige uma luta constante, levando em conta que frequentemente as diretrizes da FF entram em conflito com os princípios do TBC. Sobre isso, aponta-se que na última portaria o pedido de aumentar a representatividade da comunidade no Grupo foi negado.

\begin{tabular}{|c|c|}
\hline Principais atores & Atuação \\
\hline Associações comunitárias & $\begin{array}{l}\text { Principais responsáveis pela a promoção do turismo } \\
\text { comunitário, por meio da manifestação de interesse, articulação } \\
\text { interna e externa, centralização das negociações, deliberações } \\
\text { coletivas e aplicação do novo regramento. }\end{array}$ \\
\hline FCT & $\begin{array}{l}\text { Fortalecimento da articulação interna e do reconhecimento } \\
\text { sociocultural coletivo, e viabilizador da rede de apoio para } \\
\text { amparo às associações. }\end{array}$ \\
\hline OTSS & $\begin{array}{l}\text { Principalmente suporte técnico à comunidade e associações para } \\
\text { o planejamento e efetivação do turismo comunitário. }\end{array}$ \\
\hline LDA & $\begin{array}{l}\text { Principalmente suporte financeiro à comunidade e associações } \\
\text { para o planejamento e efetivação do turismo comunitário. }\end{array}$ \\
\hline Travessia & $\begin{array}{l}\text { Assessoria jurídica, em especial voltada à articulação das } \\
\text { associações com atores externos, e de TBC, para coesão interna } \\
\text { e estruturação no turismo comunitário. }\end{array}$ \\
\hline MPF & $\begin{array}{l}\text { Responsabilização dos atores, fomento ao ordenamento e gestão } \\
\text { coletiva para uso sustentável da Ilha das Couves e fiscalização. }\end{array}$ \\
\hline $\mathrm{FF}$ & $\begin{array}{l}\text { Normatização do regramento por meio de portarias, após revisão } \\
\text { e autorização da própria FF. }\end{array}$ \\
\hline
\end{tabular}


Marinha

Marinha
ATNU

Fiscalização e facilitação do curso ESEP para regularização dos barqueiros de Picinguaba.

Articulação dos agências privadas de turismo náutico de Ubatuba para a negociação e acolhimento do novo regramento.

Figura 21. Quadro-resumo dos atores mapeados e suas respectivas participação do ordenamento e gestão comunitária da Ilha das Couves. 


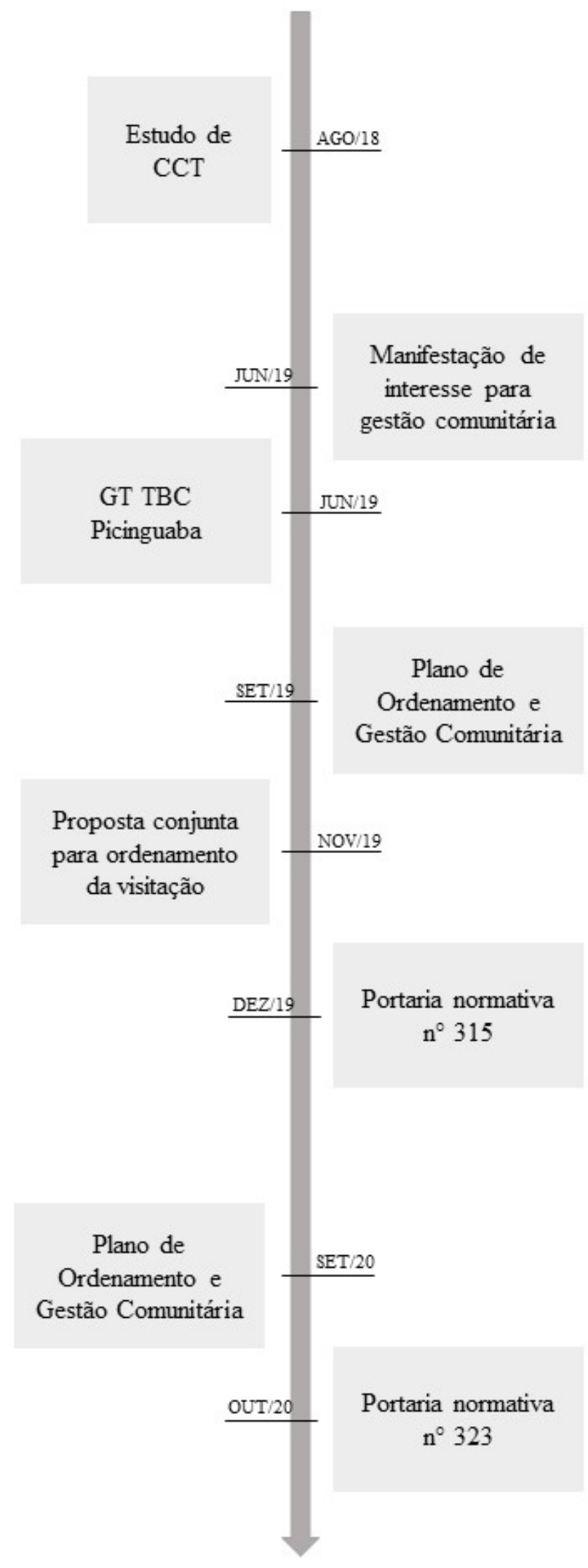

Figura 22. Linha do tempo com as principais medidas no processo de ordenamento e gestão comunitária do uso público no território de Picinguaba. 
Como conclusão desta seção, foram estruturadas duas figuras (21 e 22) referentes à síntese dos atores mapeados e funções desenvolvidas, e as principais medidas adotadas nesse período. A seção seguinte tem como objetivo apresentar os impactos do ordenamento e gestão comunitária da Ilha das Couves para as dimensões socioeconômicas e ambientais do território de Picinguaba.

\subsection{O TERRITÓRIO PÓS ORDENAMENTO: REPERCUSSÕES E IMPACTOS SOCIAIS, AMBIENTAIS E ECONÔMICOS}

O longo e intenso processo do território tradicional caiçara de Picinguaba passou a surtir efeitos antes mesmo da consolidação das ações e normas de regramento. Entre impactos positivos e negativos, é preciso reforçar que a comunidade está passando apenas pela sua segunda vivência em alto temporada com as novas diretrizes e arranjos, o que nos faz entender que ainda há muito para caminhar. Como observado na seção anterior, entre uma alta temporada e outra já foi possível perceber avanços rumo ao aprimoramento da gestão.

Dentre os impactos vividos ou percebidos, um dos mais destacados no momento das entrevistas, foi a melhora na qualidade de vida da comunidade. Essa melhora é reflexo de diferentes avanços com maior grau de especificidade dentro da dinâmica comunitária. Foi apontado que houve um ganho de tempo, devido a organização e centralização das vendas e saídas para a Ilha, possibilitando que os caiçaras se dedicassem à outras atividades. Também foi destacado que o fortalecimento da organização social, possibilitou uma melhora nas relações internas, promovendo modos menos violentos e mais coletivos para o manejo de conflitos.

O que mais valeu a pena hoje, eu vou dizer nós mesmos, porque vivemos nessa harmonia. No final de tarde senta, joga bola junto quando acaba o serviço. Sempre aqui no natal e final de ano a gente fazia aqui o jogo de solteiros e casados. Faz mais de 10 anos que a gente não faz isso e o ano passado a gente conseguiu fazer 2 vezes. De tarde a gente brinca. 2 reveillon que todo mundo colaborou com cerveja e tudo de graça na praia. Então há união. 
Tem desavenças ainda, mas a nossa união hoje com esse trabalho, com os barqueiros tudo junto, pra mim foi o maior desafio e hoje minha maior alegria, ver isso aqui de novo (Presidente AMBP).

O bem-estar comunitário também liga-se ao fato das mulheres caiçaras passarem a trabalhar com as vendas dos passeios no ponto único, superando situações de vulnerabilidade às quais elas eram expostas ao permanecerem nas estradas para abordar clientes.

Outra repercussão desse processo refere-se à economia local. Além de reverberar positivamente nos estabelecimentos localizados nas praias de Picinguaba, onde houve um aumento do consumo, já que os turistas passaram a permanecer no local, refletiu também em uma maior distribuição de renda entre os caiçaras, que tiveram seu rendimento relativo ao passeio para a Ilha equilibrado por meio da padronização do preço e do ponto único de vendas.

Eu percebo um impacto econômico, melhorou muito. Não se ganha mais como no turismo de massa, mas o que eles ganham hoje, eles fazem um melhor uso do que eles faziam quando o turismo era avassalador e desesperador. Um ganho muito grande também foi esse tempo que eles tem de sentar, de poder jogar, de poder conversar, as vezes um futebol até dá tempo de jogar, atividades que eles fazem juntos que não faziam mais. Um tempo maior pra família também que foi se perdendo por conta do turismo de massa que não te dá fôlego, você não consegue respirar. Foram impactos muito positivos (Interlocutora 1).

Ainda em relação a economia, há uma percepção menos positiva por parte da família caiçara que possui o restaurante da Ilha, que, como já foi citado, acabou sendo prejudicada com o ordenamento. Essa questão têm sido um dos principais desafios enfrentado pelo TBC, considerando que do mesmo modo que esse processo representou um avanço para a maioria dos caiçaras, para a família que ocupa e cuida da Ilha há pelo menos trinta anos, vem se tornando um obstáculo. Esse fator tem gerado um discurso negativo da família, pois há um entendimento que o TBC não foi para todos da comunidade, já que eles não se sentem incluídos. 
São 5 meninas dentro do bar. Elas ganham cem reais no dia. Então se eu ganho mil reais, eu pago 500 pra elas. [...] Esses $500 \mathrm{eu}$ tenho que multiplicar em que? Eu tenho o peixe, a batata, a mandioca, eu tenho o diesel, a gasolina, eu tenho o trabalho que eu fico no fogão. Sabe o que eu fiz? Falei pra elas "fica pra vocês" e estou ajudando elas a deixarem tudo limpinho. E vou montar um outro pra mim em outro lugar. Era pra mim ficar lá. [...] Vou ter que sair para contemplar a elas. Se eu não fazer isso, o que elas vão ganhar? Vai o pessoal das 8 sai às 11 e esse pessoal não gasta nada lá, é muito pouco tempo. Pra mim isso não dá, aí a gente fíca nervosa, discute. [...] TBC é para todos. Eu acompanhei a formação do TBC. O TBC é uma rede. Então o TBC tem que ser para todos ganhar. Que regra que pro filho trabalhar o pai tem que sair fora? Isso não é. Todos os filhos e irmãos vão ganhar. Isso é TBC (Interlocutora 2).

Entretanto, foi observado também que não há um discurso totalmente contrário ao turismo comunitário, levando em conta que o problema da superlotação foi superado. Nota-se que as críticas direcionam-se principalmente à reajustes de algumas medidas adotadas, sobretudo em relação ao estudo CCT que, de acordo com ela, deve ser revisado de maneira a abranger também a dimensão socioeconômica do território.

Como efeito desse processo também foi apontado a entrada da comunidade no cenário público e seu reconhecimento como organização. Segundo relatado, a comunidade de Picinguaba era entendida no setor público a partir de perspectivas hostis e desfavoráveis, prejudicando a possibilidade de articulações e diálogos direcionados à superação de conflitos nas diversas dimensões do território.

Eles [caiçaras de Picinguaba] eram tidos como desordeiros, como um monte de coisa, tem gente que ia lá falar mal deles, não participavam de alguns espaços, enfim, eram desconhecidos e, de repente, entram num cenário público pautando como querem e o que querem. E tem que viver, em alguma medida, todo esse preconceito que existe também com comunidade tradicional. "A 
não vão saber, não vão fazer, não vão isso e aquilo", e eles chegam e mostram que conseguem fazer essa coisa. [...] "A gente quer disputar, a gente quer debater, a gente quer fazer um lugar melhor, a gente quer falar o que tá errado" (Assessora de TBC Travessia).

Esse reconhecimento da comunidade no campo público relaciona-se também ao movimento de tomada do poder sobre o território para si, que envolveu e ainda envolve uma construção continuada da identificação sociocultural e do apoderamento do domínio daquela área a partir de sua ancestralidade.

Sobre isso, vale destacar também que, a construção de uma organização mais forte, centralizada e com maior participação no território contribuiu para uma melhor relação entre a gestão das APs ali presentes com a comunidade. De acordo com o relatado pelo presidente da AMBP, o diálogo, principalmente com o PESM, unidade com um histórico mais conflituoso, apresentou uma evolução não só para assuntos turísticos, mas também para outras questões territoriais, como conflitos de distribuição espacial, ocupação e construção em áreas proibidas pelo Parque.

Pras unidades de conservação eu também acredito que há um impacto positivo, o PESM eu acho que é de repente o maior ganhador disso porque se você apazigua a situação na vila, você tem uma condição de voltar a conversar sobre assuntos conflituosos que estavam mais à flor da pele por conta dessa situação, então quando você resolve ou minimiza um dos problemas, facilita o diálogo sobre os outros, então acho que nesse sentido o PESM sai ganhando (Coordenador executivo LDA).

Em relação a APA, o coordenador do LDA coloca que foi um ganho no sentido em que aliviou a pressão sobre aquela parte da unidade, mas por outro lado houve uma transferência da intensidade do uso para outras ilhas que também compõem a AP, como a Ilha dos Porcos e a Ilha do Prumirim, gerando um outro problema a ser mediado. 
A melhora da fiscalização foi outro impacto observado. Segundo o gestor da APAMLN, o sistema ambiental público não tem capacidade de lidar com todas as demandas que aparecem de maneira constante e presente, portanto potencializar o diálogo entre FF e comunidade e promover uma gestão comunitária contribuiu para que a APA alcançasse de maneira mais efetiva ações rumo ao seu objetivo de preservação.

Acho que o grande benefício é as comunidades se entenderem e ordenarem o território por si só. [...] o Estado não vai poder estar todo dia lá tomando conta, mesmo estando dentro da unidade de conservação, mas o Estado não ta incisivamente ali todo dia. Então o ordenamento das comunidades, o comum acordo entre eles, atendendo claro o conceito ambiental é super relevante pra gente, que dá uma descentralizada no nosso processo de ordenamento. Não é se esquivar, mas é ter mais um braço lá, vamos dizer assim, articulado também com os nossos pensamentos. Então é Picinguaba e Ilha das Couves é uma coisa que eu quero fazer pra várias outras ilhas, mas não tenho condições, então se tem esse piloto já tocado, beleza. É como se fosse um braço da unidade, devidamente capacitado para tal e que fomenta o processo. Então essa é uma vantagem (Gestor APAMLN).

Na fala acima, destaca-se também a relevância da experiência como arranjo de uso público inovador, tornando concreta a possibilidade de estendê-la a outros cenários semelhantes. Para o diretor executivo da FF, os atores conseguiram "criar um modelo que rompeu uma paradigma e que agora tem base para replicar".

O oferecimento de um turismo de maior qualidade foi um outro aspecto positivo conquistado neste período. Além da limitação do número de visitantes que proporcionou praias mais tranquilas e vazias, houve também o ordenamento marítimo, que possibilitou a demarcação e separação entre áreas destinadas ao mergulho e banho e áreas destinadas ao embarque e desembarque. Outra questão que permitiu esse melhora, foi que o processo obrigou uma maior articulação das empresas turísticas, fazendo com que houvesse maior organização quanto o horário e o volume de turistas de cada embarcação. 
Como positivo eu vejo o ordenamento mesmo, a quantidade diminuiu, isso facilita muito as pessoas irem e conhecerem a ilha de uma forma mais tranquila. A ilha não é grande [...] então você não tem esses trechos compridos que você pode passear e tudo mais. Ali você atravessou um pedacinho já está na outra praia. Então o ordenamento facilitou bastante esse trânsito das pessoas e o impacto ambiental muito menor, não tenha dúvida. Então pra mim foi bem importante esse lado. E positivo também organizar as empresas de ir pra lá (Vice-presidente - ATNU).

Entretanto, sobre a organização do setor turístico, o vice-presidente da ATNU aponta que isso ainda é uma dificuldade a ser enfrentada, considerando que há muitas empresas que não são associadas e acabam criando alguns problemas quanto ao regramento comunitário.

Em relação aos impactos ambientais foi relatado o reaparecimento de vida marinha, a diminuição da produção de lixo, a menor poluição sonora, principalmente ocasionada pela diminuição e regramento do acesso das embarcações, e uma menor ocorrência de dejetos pelo trilha ou na parte vegetada. Contudo, também foi ressaltado que o problema do saneamento básico não foi resolvido, considerando que exige uma maior análise e equipe para definir onde e como os banheiros serão construídos.

Segundo o presidente da ABPTP, a verba para a construção de banheiros tanto na Ilha quanto na vila está garantida através do fundo coletivo do TBC, entretanto, as associações estão enfrentando dificuldades em dar prosseguimento ao assunto, devido a obstáculos impostos pela FF. Sobre esse tema, algumas questões apareceram: de acordo com a gestora do núcleo, o parque não tem restrição ambiental para essa construção e sim uma restrição geográfica, levando em conta que os espaços disponíveis na vila são de terceiros, ou seja, não há um espaço da comunidade que possibilite a implementação de um banheiro; conforme o gestor da APA, há também uma complexidade relacionada a escolha de um melhor sistema de saneamento para Ilha, bem como a necessidade de refletir sobre manutenção e limpeza.

A partir de um panorama geral dos avanços viabilizados com o ordenamento coletivo, para o representante do FCT houve uma certa contemplação de todas as dimensões sob 
as quais a ideia de sustentabilidade se constrói - economia, meio ambiente e sociedade. Com isso, foi garantido que a comunidade não perdesse sua principal fonte de subsistência, amadurecesse em suas relações e diálogos, e contribuísse para a longevidade dos recursos naturais de seu território. Um pouco do que simbolizou essa trajetória, pode ser entendida com essa fala de um dos caiçaras que mais ativo na luta:

Eu acho que a comunidade pra mim, se continuasse do jeito que tava em 2018, eu não queria estar aqui mais. Eu iria me mudar, mas hoje ordenado e vendo que a própria comunidade precisa de ajuda, precisa de apoio, a galera precisa se unir mais, eu acho que

é futuro. Eu tenho duas filhas, então eu vejo um futuro em Picinguaba. Dá pra se viver muito bem aqui ainda (Presidente ABPTP).

À vista do que foi pormenorizado nessa seção, entende-se que o ordenamento e gestão comunitária para o uso sustentável da Ilha das Couves trouxe avanços significativos ao território tradicional caiçara de Picinguaba, relacionados ao bem-estar socioeconômico e ambiental alcançados em diferentes âmbitos do processo. Contudo, pontua-se também que ainda há a necessidade de regulação de alguns pontos, o que se justifica pelo caráter complexo e processual do TBC, como discutido na seção seguinte.

\section{O ORDENAMENTO E GESTÃO COMUNITÁRIA DE PICINGUABA: REFLEXÕES À LUZ DA FUNDAMENTAÇÃO TEÓRICA}

A análise do território de Picinguaba e Ilha das Couves permite entendê-lo como produto histórico produzido a partir de territorialidades que conversam, se misturam e disputam entre si. A presença dessa multiterritorialidade contemporânea naquele espaço reflete um amplo processo de desterritorialização e reterritorialização que propiciou a sedimentação de novas territorialidades, sucedendo em uma sobreposição hierárquica, em que cada uma delas se ancora em relações distintas com a terra e com os recursos naturais.

A primeira e mais simbólica territorialidade, que há décadas confere feições específicas àquele território, ganhou contornos a partir da reprodução sociocultural caiçara. Ela envolve uma perspectiva do território pautada pela integralidade, onde 
Picinguaba e Ilha das Couves assumem papéis indissociáveis dentro de um todo. A Ilha é compreendida como parte do território - ou "maretório" - caiçara, que é composto também pelo sertão e vila de Picinguaba, mata atlântica, praias, mar e outras ilhas.

Mais do que no discurso ou nas práticas, essa territorialidade se expressa na extrema dependência socioeconômica de recursos naturais adquiridos diretamente da área, sem introdução de capital pela comunidade definindo, assim, seu território. Não há uma forte apropriação da narrativa da tradicionalidade nas falas dos comunitários, muitas das atividades tradicionais caiçaras deixaram de ser realizadas ou tornaram-se menos importante para subsistência quando comparadas ao turismo, contudo aquele território e seus recursos ainda representam a única ou a principal fonte de sustento para a maior parte da comunidade.

A vida financeira da vila, da comunidade, está ligado à Ilha das Couves. Não ter mais a Ilha pra gente trabalhar o turismo é o fracasso da comunidade. É o fracasso social, econômico, é a ruína (Interlocutora 1).

É nosso habitat porque é dela que nós precisamos. É nossa casa. Nós vivemos disso daqui. Hoje tem o turismo, mas antes era a pesca. Criei meus filho com a pesca, com meu marido no barco (Interlocutora 2).

Meu envolvimento aqui é ter nascido aqui, lógico, minha família é daqui, pesco aqui, e trabalho aqui. Então meu envolvimento aqui é constante. É o primeiro lugar da minha subsistência (Presidente - ABPP).

Bem dizer que o território é o coração da comunidade. Se a gente perder isso tudo acabou a vida da Picinguaba. Porque se você acaba com uma ilha que você tem, uma praia que você tem, não tem mais lógica. Acaba tudo. Eu acho que é o que a gente tem. É isso. Pode ir embora daqui pra outro lado. Porque sair daqui é pra morrer (Vice-presidente - AMBP). 
Pra mim é tudo. Minha casa, onde eu nasci, onde eu vivi, o mar é seu quintal de onde você tira seu sustento. Pra mim representa tudo na vida. Picinguaba em vez de minha casa, é minha vida (Presidente - AMBP).

O esforço em direção ao fortalecimento dessa territorialidade dentro dos arranjos de poder que se fazem presentes ali, teve papel crucial para fundamentar a argumentação sob a qual a luta para a garantia da Ilha das Couves se constituiu. Esse movimento se deu de duas principais formas: pela retomada da história de uso e ocupação da Ilha, como forma de demonstrar a estreita e longa relação entre comunidade e território e a este respeito, a presença de uma família caiçara na Ilha foi determinante para tornar a demonstração mais substancial; e pela identificação e fortalecimento do autoreconhecimento como comunidade tradicional, que pertence e reivindica o direito de controle sobre seu território.

Uma outra territorialidade ligada à políticas preservacionistas se faz presente a partir de duas áreas protegidas que, apesar de respaldadas pela mesma legislação e órgão público, se relacionam de maneiras distintas com o território, impossibilitando a um olhar genérico sobre elas. Um primeiro ponto a se destacar de confronto com a territorialidade caiçara é o entendimento e apropriação segmentada do território pelas políticas ambientais, partindo de diferentes premissas para o estabelecimento de núcleos de gestão atuantes em parcelas específicas daquela área, que não necessariamente se conversam no processo gestor.

Essa dissonância de fundamento que permeia a territorialidade preservacionista influencia o modo com que as pontes de diálogo são construídas entre Estado e comunidade. De acordo com o gestor da APAMLN, todos os usos tradicionais no território estão garantidos no decreto de criação e no plano de manejo da APA, o que contribui para uma aplicação menos restritiva e mais participativa de suas políticas. Ainda segundo ele, a conservação só é possível se correlacionada com aspecto social e cultural da área, e arranjos coletivos como o realizado em Picinguaba representam um avanço nessa correlação e estão entre os objetivos da APA.

Por parte da comunidade, foi observado que há um melhor relacionamento com a APA pela a garantia de uso sustentável. Mesmo assim, foi apontado que apesar da APA 
abranger os usos tradicionais, há também a incorporação de outros usos, o que por vezes interfere diretamente no desenvolvimento das atividades caiçaras, sendo os caiçaras obrigados a moldarem e reduzirem suas práticas.

Já a territorialidade preservacionista analisada sob a dimensão do Parque, tornase uma pouco mais nebulosa e conflituosa a medida em que remete à um período e a uma fundamentação teórica e jurídica maciça e inflexível. A partir disso, foi possível perceber uma diferença entre discursos dos gestores da APA e Parque. Conforme a gestora do PESM aponta em relação a Picinguaba, não há um olhar otimista sobre a relação entre a proteção do meio ambiente e da cultura, devido principalmente a alta descaracterização que a comunidade sofreu. Assim, e ainda de acordo com ela, o processo de resistência para a permanência no território traz desafios e pode ser entendido de certa forma negativo considerando seu papel de gestor que objetiva a máxima proteção dos recursos naturais da região.

Entretanto, apesar da desconfiança mútua originadas na forma de criação e implementação dessa áreas, dois relevantes pontos foram observados: 1) em grande parte dos discursos de atores externos ao Estado, houve certa compreensão sobre a importância do PESM em se opor à ofensiva de novos usos e ocupação em determinado momento histórico, o que garantiu a continuidade de grande parte da comunidade em seu território, mesmo que com suas práticas reduzidas ou criminalizadas; 2) tanto por parte da Fundação florestal quanto da comunidade, houve a percepção que após a gestão coletiva do turismo a relação entre atores vivenciou um aprimoramento, se estendendo inclusive à outros temas relativos ao território.

A terceira e mais recente territorialidade ali expressa, se construiu a partir do avanço da atividade turística e ações adjacentes. Do mesmo modo que a preservacionista, a apropriação territorial se deu de forma seccionada, porém com uma configuração distinta. É possível compreender que essa territorialidade se coloca ainda mais desconexa quando comparada à preservacionista, no momento em que envolve a exploração econômica de diversos componentes do território tradicional de Picinguaba, porém com baixos níveis de planejamento e gestão, o que impede possibilidades de uma noção mais integral. 
A territorialidade turística também assume uma sedimentação no território com características menos consistentes, mesmo possuindo uma atuação forte e constante. $\mathrm{O}$ apoderamento da área principalmente pelos atores relacionados a iniciativa privada orienta-se por uma perspectiva basicamente econômica, o que possibilita ou facilita que um local passe ou deixe de ser explorado. Isso pode ser percebido no relato a seguir do vice-presidente da ATNU.

Não, na verdade, como que eu posso te colocar isso, não é o principal local [Ilha das Couves], não é a principal subsistência de todos. Como eu falei, nós temos mais 3 ilhas aqui, fora outros lugares que a gente pode levar o pessoal pra passear. Então não é o único ponto. Tem outros lugares iguais à Ilha das Couves. [...] O turismo é voltado para várias coisas.

A multiterritorialidade que se remonta nesse território, conforme proposto por Haesbaert (2005), demonstra territorializações que envolvem níveis distintos de descontinuidade, ao mesmo tempo que seus limites se materializam com mais ou menos rigidez. Isso resultou em um território seccionado por linhas principalmente simbólicas e abstratas, onde em cada parte há uma multiplicidade de atores divergente às outras. $O$ fato desse território assumir características mais próximas ao conceito de um território-rede ao mesmo tempo em que trouxe desafios devido à pluralidade e segmentação, possibilitou um campo mais fértil para que ações de ordenamento descentralizadas e coletivas encontrassem espaço nas políticas de gestão.

Nas últimas quatro décadas, como já foi demonstrado, houve um desequilíbrio quanto ao desenvolvimento das territorialidades no local, explicitando os altos níveis de sensibilidade da dimensão caiçara frente às outras. Nesse sentido, observa-se que o ordenamento e gestão coletiva do uso turístico no território pode ser interpretado também como uma conquista direcionada ao balanceamento da expressão dos poderes que cada territorialidade impõe ao território.

A análise do que foi esse processo permite identificar noções da governança ambiental, considerando que enquanto não houve uma articulação ampla e convergente entre os atores envolvidos não foi possível mitigar a exploração socioambiental que o território vinha sofrendo. Sobre isso, faz-se necessário uma divisão temporal, mesmo 
incompleta, do processo: até 2018, como foi mostrado, diversas ações foram propostas, mas todas de maneira pontual, sem que houvesse uma organização concreta e elaboradas fora do âmbito coletivo; a partir de 2019, observa-se um movimento acentuado para centralização das decisões, possibilitando a aplicação efetiva de ações.

Para que essa centralização de decisões e ações fosse possível, destaca-se a atuação de três atores: MPF, associações locais e FCT. Em um primeiro momento, muito devido a atuação do MPF, houve um chamamento para que a Fundação Florestal e outros atores assumissem suas responsabilidades para com a área. Em um segundo, as associações e FCT criam um espaço decisório, que até então não existia (pelo menos, não na prática), e possibilitam com isso o encontro de todos os interessados para discussão e deliberações. Aqui, faz-se necessário destacar o deslocamento do espaço decisório para fora dos limites oficiais das instâncias do Estado, o que resulta em uma nova arena de negociação representada pelo GT TBC.

A criação desse espaço por iniciativa da comunidade indica uma ação política mais profunda, indo além da ideia de uma consulta ou comunicação. Corroborando com o proposto por Dinica (2017b), observou-se que a gestão territorial não só conteve, como foi direcionada por elementos abstratos e materiais agregados pela comunidade. Um exemplo é a taxa destinada ao fundo coletivo da comunidade, a qual é possível interpretar em seu sentido concreto, relacionado à necessidade de aprimorar a infraestrutura local para bem-estar dos turistas e habitantes, e em seu sentido simbólico, que envolve o entendimento do território como parte constituinte da comunidade, assegurando que a sua utilização reverta necessariamente em benefícios para seus moradores.

Ainda sobre a participação pública, principalmente da comunidade caiçara de Picinguaba, chama-se atenção para outros três avanços observados: (i) foi possível uma distribuição mais eficiente e igualitária dos recursos naturais e aqui destaca-se a elaboração de turnos priorizando os barqueiros tradicionais; (ii) conforme proposto por Connel (1997 apud OKAZAKI, 2008), o engajamento permitiu também o desenvolvimento pessoal, refletindo principalmente na capacidade de articulação interna da comunidade; (iii) além da redistribuição, houve um redesenho nos custos e benefícios, no sentido que alguns foram superados ou perdidos para dar espaços à outros, isso foi 
observado, por exemplo, no cenário interno à comunidade, onde alguns poucos caiçaras deixaram de obter altos lucros para que renda entre todos fosse equalizada.

Ao aplicar o processo de ordenamento e gestão coletiva desenvolvido em Picinguaba à "escada de participação cidadã" (Figura 8) proposta por Okazaki (2008), entende-se que a comunidade adentrou ao último nível do engajamento, por meio da estruturação de um arranjo que se assemelha a ideia de parceria. De acordo com o autor, parceria envolve redistribuição do poder por meio da negociação entre cidadãos e tomadores de decisão. No caso de Picinguaba, é interessante observar que mesmo havendo um deslocamento do espaço decisório e uma priorização das deliberações comunitárias, a comunidade ainda não possui poder legal, dependendo principalmente da FF para normatizar o que foi decidido.

Essa dependência poderia se limitar ao campo simbólico se houvesse um total aceite da FF como órgão apenas normatizador das diretrizes estabelecidas nos espaços coletivos da comunidade. Entretanto, a interpretação do processo permite notar que por algumas vezes as solicitações comunitárias foram negadas ou algumas condições foram impostas, como a necessidade de abranger o trade turístico ou aplicar a limitação máxima oriunda de um estudo não participativo. Esse fator exigiu que houvesse negociação constante entre atores, explicitando os limites ainda presentes da participação cidadã.

Em relação ao "modelo evolutivo de parcerias de turismo" proposto por Selin e Chavez (1995), observa-se a presença das cincos fases do processo no caso da Ilha das Couve, porém não executadas obrigatoriamente uma seguida da outra ou em um espaço de tempo bem delimitado.

(1) É possível entender que a fase que envolve os antecedentes estendeu-se por todo o período entre 2016 e 2018, quando circunstâncias e ligações determinantes ocorreram. Sobre isso, evidencia-se a criação das duas associações de barqueiros e o fortalecimento da associação de moradores como lideranças dispostas a atuar na questão turística; as tratativas com o MPF, que possibilitaram a construção gradual de uma noção por parte da comunidade sobre a fragilidade daquele cenário de exploração; e a realização do estudo CCT, o que moldou todo o processo posterior de ordenamento. 
(2) A fase de definição de problemas pode ser observada em dois momentos distintos: o primeiro, ocorrido entre 2016 e 2018, onde houve um foco no levantamento dos problemas ambientais por agentes externos ao território; e o segundo, ocorrido no movimento de elaboração do POGC, no qual a identificação dos problemas passa a ser realizada pela própria comunidade e extrapola os limites da visão ambiental, abrangendo os impactos socioculturais do turismo.

(3) A fase de definição de direção também se deu de forma segmentada, apesar que seu desenvolvimento mais robusto veio com a entrada do FCT, suscitando na criação do GT e criação do plano, ambos instrumentos decisivos para ditar os rumos da parceria.

(4) O momento de estruturação também aconteceu de forma diluída, considerando que antes, durante e depois da criação do GT e do POGC houveram momentos de formalização de relações e compromissos, bem como de subprocessos. Conforme proposto por Selin e Chavez (1995), essa fase compreende métodos de controle. No caso de Picinguaba houve a construção de ferramentas para monitorar o volume de visitação, revezamento de barqueiros e as entradas e saídas do fundo coletivo. Contudo, não houve a elaboração de técnicas para dimensionamento do impacto socioambiental do processo.

(5) Apesar de na fase anterior não terem sido elaborado um sistema de monitoramento, foi observado que os resultados foram analisados a partir dos interesses de cada ator envolvido, sendo necessário novas negociações e ajustes. O processo avaliativo foi amplamente expresso na nova portaria, na qual alterações relacionadas à tentativa de superar algumas lacunas foram realizadas.

Acerca da análise bidimensional da Figura 8, três pontos dos cinco propostos por Okazaki (2008) chamam atenção quando comparados ao processo de gestão coletiva de Picinguaba. A redistribuição de poder no território só foi possível por meio da promoção da participação da comunidade que, com base na interpretação de dados, entende-se que se deu por dois principais vetores que convergiram em um determinado momento: o interesse da Procuradora responsável em incluir e responsabilizar os moradores locais e a disposição da comunidade em assumir as responsabilidades da gestão para garantir sua 
permanência. Nesse ponto, destaca-se também a colaboração da FF em aceitar, mesmo que não completamente, uma atuação mais forte e direta da comunidade.

Outros dois pontos evidenciados na análise bidimensional e que estão intimamente ligados dizem respeito ao processo colaborativo como necessário para que a participação e redistribuição ocorram e a necessidade de se construir capital social para que a sinergia entre atores internos e externos seja alcançada. Sobre isso, nota-se que mesmo com o interesse por parte do MPF em envolver a comunidade, enquanto não foi promovido um processo de fato colaborativo, a possibilidade de partilha do poder de gestão não se concretizou. Para isso, foi imprescindível a construção das três formas de ligação que figuram o capital social.

O capital social de ligação, como indicado por Marteleto e Silva (2004), representa a consolidação das relações de base, realizadas em nível mais próximo e intímo do território. O fortalecimento desse capital ainda é um desafio para a comunidade, considerando o histórico de conflitos e ressentimentos internos. Por outro lado, foi observado seu avanço para que houvesse o compartilhamento de informações, promoção de diálogos e o consenso quanto às normas e estratégias.

Ainda sobre a conquista desse capital, compreende-se sua relevância para que alguns princípios de regimes de propriedade comum propostos por Ostrom (1990) fossem adotados. Entre eles, destacam-se os que se sobressaíram no processo em questão: definição coletiva de regras, possibilitado pelo GT e formalizado pelo plano; alinhamento da atividade exploratória com a capacidade do espaço, apesar da capacidade de suporte não ter sido delineada coletivamente, as ações a partir do estudo se direcionaram a abrigar todos os barqueiros de maneira equitativa; reconhecimento da organização comunitária pelo poder público, concretizado principalmente após o fortalecimento da articulação interna; e cooperação com outros níveis de gestão e mais que isso, defesa de suas aspirações frente a outros atores.

O avanço do capital social de ligação no sentido da tomada parcial do poder territorial dependeu, como citado anteriormente, do aprofundamento das relações com diferentes instâncias do poder público, integração que remonta o capital social de conexão. O interesse mútuo entre comunidade e MPF em manter um constante diálogo fortaleceu a possibilidade política e institucional de um campo de atuação para a 
organização comunitária em detrimento a outras iniciativas que haviam interesse na área. Entretanto, compreende-se que o principal progresso relacionado a este capital refere-se ao aperfeiçoamento do canal de comunicação com a FF, considerando o caráter duradouro do seu papel gestor do território. De qualquer modo é necessário pontuar que esse diálogo, apesar do avanço, pode em determinado momento retroceder, principalmente devido a instabilidade da FF em relação à seus dirigentes e sua visão política-institucional.

Ao mesmo tempo em que se observou o aumento da conexão entre os âmbitos estatais e não-estatais, ainda foi possível identificar no processo ações pautadas pela visão institucional com potencial de frear ou anular iniciativas vinculadas ao capital social de ligação. Esse movimento se deu sobretudo por exigências advindas do MPF, como obrigações burocráticas ligadas à manifestação de interesse inicialmente para o TAUS e depois, para a gestão coletiva, como também a construção de um plano de ordenamento e gestão para uso sustentável como condicionante.

À vista disso, compreende-se que as limitações institucionais aumentaram a necessidade de articulação externa entre a comunidade com organizações do terceiro setor e movimento social. A estruturação da rede de apoio à comunidade, ou do capital social de ponte, se deu essencialmente a partir de uma rede de maior amplitude na qual o FCT tem papel central. É interessante pontuar que todos os atores que adentraram ao território de Picinguaba junto ao Fórum, já estavam de maneira mais ou menos intensa presente em seu capital social de ponte, tornando o movimento mais robusto e potente. Essa rede se fez fundamental em um duplo sentido: na superação de limitações jurídicas, institucionais e técnicas pela comunidade, preenchendo lacunas não suprimidas na relação Estadocomunidade; e na fortificação no capital social de ligação, sobretudo na recuperação da identidade histórico-cultural e na coesão entre o grupo.

A recuperação da trajetória sociocultural da comunidade representa uma das premissas do turismo de base comunitária, como forma de auto-reconhecimento, construção de uma noção identitária e de valorização da sua cultura e do seu povo, possibilitando assim o desenvolvimento de uma atividade turística que envolva uma troca de conhecimento visando o estímulo à percepção socioambiental concreta. A compreensão do processo de gestão coletiva permite entender que o que foi desenvolvido no território tradicional caiçara de Picinguaba trata-se de uma semeadura da organização 
social coletiva que, se estimulada, tem potencial para se tornar de fato uma gestão comunitária orientada pelos princípios do TBC.

A partir da construção teórica sobre conceitos, premissas e práticas do TBC, houve o esforço em entender quais foram os principais alcances e iniciativas coletivas dentro do processo estudado que representam um princípio do longo decurso no qual o TBC se materializa.

(a) Houve a reivindicação e conquista do direito ao uso e maior controle do território, sendo a representação máxima desse feito a interrupção do processo de cessão da Ilha das Couves para a iniciativa privada;

(b) Muitas ações afetaram positivamente o desenvolvimento local, não apenas em sua dimensão econômica, como social. Sobre isso é possível citar a redistribuição de renda originada no turismo da Ilha, a cobrança de taxa para o aprimoramento da infraestrutura, a diminuição e organização do trânsito em alta temporada, garantido a locomoção de melhor qualidade aos moradores, entre outras;

(c) Houve um avanço efetivo em direção a mitigação dos impactos ambientais ocasionados pelo turismo. Coletivamente, isso se deu por meio do ordenamento do trânsito de embarcações, desafogando as praias e reduzindo a poluição sonora, determinação de regras de mínimo impacto, organização da coleta de lixo, entre outras;

(d) Parte da economia do bairro de Picinguaba assumiu características da economia solidária a partir da partilha igualitária do lucro dos passeios, da criação de um fundo coletivo, da incorporação das mulheres ao ponto único como vendedoras, da padronização dos valores e ponto de venda dos passeios, etc;

(e) Foi observado um deslocamento factual do posicionamento da comunidade em relação à atividade turística, na qual foi assumido um protagonismo comunitário expresso principalmente pela elaboração de diretrizes que tinham o foco central o aumento da qualidade de vida dos caiçaras.

Alguns outros elementos relevantes à construção do TBC não foram identificados de forma consistente. O primeiro ponto refere-se à falta da inclusão de práticas voltadas 
à valorização da identidade cultural durante o roteiro turístico para a Ilha das Couves, no qual não há troca de informações sobre as atividades tradicionais para subsistência caiçara. Nota-se que durante o trajeto até o destino final é possível ver um cerco flutuante, estruturas para maricultura, outras ilhas e elementos da paisagem que possuem significados místicos aos caiçaras locais. Outro ponto a ser aprofundado é o alcance da compreensão do que de fato é o TBC pela comunidade. Foi observado que a sigla TBC foi popularizada entre a comunidade, mas o entendimento mais a fundo se restringiu apenas aos comunitários que participaram ativamente da organização ${ }^{49}$.

O desafio de retomar o reconhecimento sociocultural entre a comunidade explicita o que Calvente (2016) coloca como desterritorialização simbólico-cultural. Grande parte da comunidade de Picinguaba permaneceu em seu território após a chegada da rodovia e da especulação imobiliária, mesmo assim houve uma fragilização das relações com o lugar que se constituíram a partir da absorção de novas formas de trabalho, cultura e sociedades. Ainda corroborando com a autora, essa realidade dificulta a construção e a efetivação de uma organização coesa focada em controlar e manejar seu território.

Apesar de haver algumas questões a serem superadas, o processo vivido pela comunidade ensejou uma mudança comportamental direcionada a proteção dos recursos naturais e respeito às regras coletivas, se aproximando do papel de guardiã do território proposto por Bollier (2016). Em um primeiro momento, observou-se que a organização comunitária estava sendo pautada principalmente pela garantia de poder continuar desenvolvendo o turismo na Ilha como principal atividade econômica. Em um segundo, após a construção e implementação coletiva, foi percebido a absorção gradual de uma perspectiva que envolve efetivamente a busca pela qualidade socioambiental do território.

Nesse sentido, compreende-se que o estímulo à redistribuição de poder no território de Picinguaba representou um progresso em relação aos objetivos de preservação ambiental das áreas protegidas instituídas ali. Primeiro, houve uma mudança

\footnotetext{
49 Durante a vivência em campo, mais precisamente no começo de janeiro de 2020, houve uma reunião promovida pelo GT TBC para encaminhar algumas questões, considerando que a maioria das ações já tinham sido colocadas em práticas, na qual teve um dos maiores números de participação dos barqueiros. $\mathrm{Na}$ ocasião, um grupo grande questionou de maneira mais agressiva o que era o TBC e qual destino estava sendo dado ao dinheiro que estavam arrecadando. Devido aos ânimos exaltados, a reunião teve que ser encerrada sem que as pautas fossem continuadas.
} 
relacional entre comunidade e órgão gestor, diminuindo os níveis de desconfiança e aumentando os de cooperação. Segundo, a comunidade como maior interessada em manter aquele território, assumiu uma postura de articuladora entre todos os atores envolvidos, tirando essa responsabilidade do órgão gestor que não possui capacidade de lidar com essa questão de maneira constante e potente. Terceiro, a comunidade apropriouse da função fiscalizadora, o que também se faz fundamental à medida que, como foi demonstrado, os órgãos públicos não desempenharam de maneira eficiente o monitoramento da área.

\section{CONSIDERAÇÕES FINAIS}

A multiterritorialidade originada a partir do território de Picinguaba deu origem a um cenário intenso de conflitos que envolvem a degradação ambiental, cultural e social do local. As três principais territorialidades identificadas possuem níveis de dependência e disputa entre si. Seu caráter relacional compõe-se pelo turismo como principal atividade de subsistência e principal fonte de impacto socioambiental, pelas políticas de preservação ambiental que ao mesmo tempo em que pressionam a existência caiçara, garantem sua continuidade e de seus recursos, e pela tradicionalidade caiçara, que por dependerem exclusivamente daquele território podem assumir tanto o papel de predador quanto de protetor.

As diferentes apropriações territoriais do mesmo espaço geraram um cenário cuja complexidade associa-se à presença de inúmeros atores envolvidos em arranjos distintos, com interesses divergentes e diferentes graus e tipos de ligações com o território. Ao se analisar o processo de ordenamento turístico frente ao contexto de conflitos socioambientais ali estabelecido, é possível entender que houve uma incapacidade do Estado em garantir por si só a saúde social, econômica e ambiental da área, mesmo valendo-se de três esferas de gestão pública: Fundação Florestal, Prefeitura e União. 
A partir dessa compreensão, alguns pontos determinantes para o regramento efetivo do turismo foram observados: a mitigação do cenário colocado só se concretizou após uma articulação mais robusta dos atores envolvidos, envolvendo a participação concreta e graus de redistribuição de poder; o Estado depende diretamente da ação dos moradores locais para garantir a implementação das novas regras de uso; quando as diretrizes chegam com maior nível de hierarquização, a dificuldade de aceitação e materialização é mais alta.

O engajamento público do qual o Estado é dependente para alcançar mais eficientemente a conservação ambiental, analisado sob um contexto de comunidades tradicionais, mostra-se dependente de um capital social que cumpra lacunas em diferentes esferas da atuação. Entende-se que a ação mais contundente da comunidade caiçara de Picinguaba, mesmo com o fomento do MPF, só foi possível após a estruturação de uma rede de apoio que representou a qualificação da organização para assumir de fato a posição de gestores.

Sob a perspectiva da comunidade, constatou-se que a união e fortalecimento das associações locais como instrumento jurídico foi decisivo para que a negociação mais igualitária com o poder público e outros atores a partir das demandas do território se concretizasse. Do mesmo modo, o avanço da atuação das associações exigiu a superação de algumas questões internas em prol da concepção de um olhar voltado à coletividade.

Além do engajamento público, verificou-se que a concretização e sucesso para parcerias com comunidades para o desenvolvimento do turismo sustentável em áreas protegidas depende também de instrumentos que possibilitem o diálogo constante e aprofundado, e que forneçam direcionamentos para o manejo. No caso estudado, os principais instrumentos criados durante o processo preencheram as seguintes brechas: a falta de um espaço para diálogo e centralização das negociações especificamente sobre o uso turístico dos recursos naturais; e a carência de um documento com as diretrizes estabelecidas e a responsabilidade de cada ator.

O desenvolvimento deste estudo possibilitou constatar também que a parceria entre poder público e comunidade para a estruturação de um turismo de base comunitária desatou alguns nós relacionais que tensionavam o território. Nesse sentido, a pesquisa corrobora para o avanço de práticas de gestão que democratizem os espaços decisórios, 
promovendo maior consenso entre órgãos gestores e comunidades a fim de torná-los parceiros nas fases de planejamento, aplicação, fiscalização e avaliação. Esse aprimoramento relacional para uma gestão mais participativa permite se alcançar de maneira mais cabível o equilíbrio entre a exploração econômica dos recursos, a qualidade de vida dos habitantes e a vitalidade dos ecossistemas.

Além da relação com o poder público, observou-se também que o apoderamento da comunidade e a possibilidade de maior controle de seu território assegurou que o diálogo com outros atores, principalmente com as empresas privadas de turismo, acontecesse de maneira mais frequente, pacífica e contundente, no sentido de garantir que as necessidades e limites do território fossem ouvidos e priorizados.

Apesar dos avanços verificados no sentido da diluição de poder na área, é necessário pontuar igualmente as limitações observadas. A mais significante diz respeito ao movimento de restrição de poder adotado pela Fundação Florestal referente à participação da comunidade. Foi observado que essa dinâmica pode se expressar de maneira mais ou menos subjetiva em ações que pró́bem, impõem ou conduzem vigorosamente à determinado sentido, como a publicação de portarias com curtos prazos, a pressão para abranger o trade turístico ou a objeção quanto uma composição mais equilibrada do grupo de gestão.

A dinâmica de restrição de parte do poder da comunidade resulta na impossibilidade de se aplicar uma gestão comunitária em sua forma mais integral e ampla. Compreende-se que houve um alto progresso relativo à participação comunitária se comparado ao período de 2016 a 2018, contudo é possível inferir que mesmo com traços comunitários, a gestão do uso turístico está sendo desenvolvida de forma mais coletiva, onde atores externos possuem grande poder de decisão e controle sobre o território.

A dificuldade em se realizar uma gestão efetivamente comunitária do turismo, conforme foi notado, representa um obstáculo à efetivação do TBC na área, considerando que coloca a comunidade em posição de vulnerabilidade devido à sua dependência à disposição do órgão ambiental. Essa compreensão permite entender o TBC como processo temporal, histórico e político, no momento em que exige que o corpo coletivo da comunidade se mantenha atento e potente para que sua completa autonomia seja alcançada. 
Entende-se que a alta dependência de comunidades pelo terceiro setor para o alcance de realidades de maior participação demonstra a fragilidade do Estado em promover condições mais profundas e direcionadas para o estímulo do engajamento público. No caso estudado, observa-se que os espaços dos conselhos consultivos da APs, por exemplo, não foram suficiente como campo de discussão e negociação para manejar o conflito da Ilha das Couves. Com isso, é possível concluir que um possível progresso para relação entre território e gestão seria a criação de grupos ou comissões dentro de órgãos ambientais, como a Fundação Florestal, que permitam pautar e trabalhar questões com maior especificidade.

Frente aos frequentes conflitos socioambientais que permeiam áreas protegidas habitadas por comunidades tradicionais, entende-se que o presente trabalho confere uma relevante contribuição à discussão mais ampla que norteia parte da produção de conhecimento científico da temática socioambiental e aos atores que estão atuando diretamente nesses territórios, considerando que se construiu a partir de uma pesquisa empírica na qual foi possível compreender na esfera teórico-prático um caso entendido como inovador por abranger um alto grau de participação e diluição de poder, aspectos que estão na contemporaneidade adentrando mais efetivamente à práxis da governança ambiental.

O fato desse estudo se dedicar à compreensão de um processo recente e ainda incomum, chegando à conclusões relevantes e passíveis de extrapolação para outros cenários semelhantes, contribui para que a linha de pesquisa em dimensão socioambiental do Programa de Pós-graduação em Mudanças Sociais e Participação Política avance no fortalecimento do seu objetivo de produzir e respaldar novos tipos de conexão entre Estado e sociedade civil para atingir a convergência concreta e ativa entre desenvolvimento local e conservação do meio ambiente.

Para concluir, é necessário reforçar e reverenciar a importância do que está sendo o processo de ordenamento e gestão para o uso sustentável da Ilha das Couves, que frente à lógica neoliberal e seu projeto de privatizar e conceder os bens públicos naturais à iniciativa privada - demonstrou a força e a competência que uma comunidade tradicional pode demonstrar quando incentivada e apoiada e, mais que isso, a sua 
habilidade em garantir práticas que visem a longevidade dos recursos naturais quando estes estão efetivamente em suas mãos.

\section{BIBLIOGRAFIA}

ACSELRAD, H. Justiça ambiental e construção social do risco. Desenvolvimento e meio ambiente, v. 5, n. 5, p. 49-60, 2002.

ADAMS, C. As populações caiçaras e o mito do bom selvagem: a necessidade de uma nova abordagem interdisciplinar. Revista de Antropologia, v. 43, n. 1, p. 145-182, 2000.

ALTHUSSER, L. Ideologia e Aparelhos Ideológicos do Estado. Lisboa: Editorial Presença/Martins Fontes, 1970.

AMBP - Associação de Moradores do Bairro da Picinguaba; ABPP - Associação de Barqueiros e Pescadores da Comunidade Tradicional da Picinguaba; ABPTP Associação de Barqueiros e Pescadores Tradicionais da Picinguaba. Plano de ordenamento e gestão comunitária para o uso público sustentável da Ilha das Couves do território tradicional caiçara da Picinguaba. Ubatuba, 2019.

AMBP - Associação de Moradores do Bairro da Picinguaba; ABPP - Associação de Barqueiros e Pescadores da Comunidade Tradicional da Picinguaba; ABPTP Associação de Barqueiros e Pescadores Tradicionais da Picinguaba. Plano de ordenamento e gestão comunitária para o uso público sustentável da Ilha das Couves do território tradicional caiçara da Picinguaba. Ubatuba, 2020.

ÂNGELO, S. Picinguaba: Três décadas numa vila de pescadores do Litoral Norte do estado deSão Paulo. Boletim Paulista de Geografia, n. 69, p. 61 - 74, 1992.

ARRUDA, R. "Populações tradicionais" e a proteção dos recursos naturais em unidades de conservação. Ambiente \& Sociedade, v. 2, n. 5, 1999.

AUlD, G. W.; DIKER, A.; BOCK, M. A.; BOUSHEY, C. J.; BRUHN, C. M.; CLUSKEY, M.; EDLEFSEN, M.; GOLDBERG, D. L.; MISNER, R. S. L.; OLSON, B. H.; REICKS, M.; WANG, C.; ZAGHLOUL, S. Development of a decision tree to 
determineappropriateness of NVivo in analyzing qualitative data sets. Journal od nutrition education and behavior, v. 39, n. 1, 2007.

BARBOSA, S. R. C. S.; FORMAGIO, C. C., BARBOSA, R. V. Áreas protegidas, uso e ocupação do solo, qualidade de vida e turismo no litoral norte paulista: algumas reflexões sobre o município de Ubatuba. Caderno Virtual de Turismo, v. 10, n. 2, 2010.

BARDIN, Laurence. Content analysis. São Paulo: Livraria Martins Fontes, 1977.

BELGAMO, J. A.; SILVA, G. L.; SILVA; L. F.; SANTOS, L. M.; RAMALHO, D. Mitigação de impactos ambientais causados pelo over turismo em ilha das couves, ubatuba-sp: Planejamento turístico e sustentável. Revista Geociências-UNG-Ser, 19(1), 22-37, 2020.

BENSUSAN, N. Conservação da biodiversidade em áreas protegidas. Rio de Janeiro: FGV Editora, 2006.

BERGE, E. Protected areas and traditional commons: values and institutions, Norsk Geografisk Tidsskrift - Norwegian Journal of Geography, 60:01, 65-76, 2006.

BOLLIER, D. Pensar desde los comunes: una breve introducción. Madri: Traficantes de Sueños, 2016

BONI, V.; QUARESMA, S. J. Aprendendo a entrevistar: como fazer entrevistas em Ciências Sociais. Revista eletrônica dos pós-graduandos em sociologia política da UFSC, v. 2, 2005.

BORDIGNON, C. V. M. RAFAELLI, D. R.; LOPES, E. L.; SIQUEIRA, J. A. Poluição dos lençóis de água subterrâneos. Arquivos do Museu Dinâmico Interdisciplinar, v. 2, n. 1, p. 7-9, 1998.

BRANDÃO, C. R.; BORGES, M. C. O lugar da vida-Comunidade e Comunidade Tradicional. Campo-território: revista de geografia agrária, p. 1-23, 2014.

BRANDÃO, C. R.; LEAL, A. Comunidade Tradicional: conviver, criar, resistir. Revista da ANPEGE, v. 8, n. 9, p. 73-91, 2012. 
BRASIL. Decreto N. 6.040, de 7 de Fevereiro de 2007. Institui a Política Nacional de Desenvolvimento Sustentável dos Povos e Comunidades Tradicionais. Presidência da República, 2007.

BRASIL. Ministério do Meio Ambiente - MMA. Instituto Brasileiro do Meio Ambiente e dos Recursos Naturais Renováveis - IBAMA. Manual do chefe. Brasília: MMA/IBAMA, 1999.

BRASIL. SOS Mata Atlântica e INPE apresentam dados do Atlas dos Remanescentes Florestais da Mata Atlântica. Ministério da Ciência, Tecnologia, Inovações e Comunicações, 2014.

Disponível

em:

http://www.inpe.br/noticias/noticia.php?Cod_Noticia=3610>. Acesso em: 20 de outubro de 2019.

BRASIL. Decreto $n^{\circ}$ 6.040, de 7 de fevereiro de 2007. Institui a Política Nacional de Desenvolvimento Sustentável dos Povos e Comunidades Tradicionais. Brasil, 2007.

BRASIL. MPF inicia projeto socioambiental para preservação da Ilha das Couves, em Ubatuba (SP). Ministério Público Federal, 2017. Disponível em: < http://www.mpf.mp.br/sp/sala-de-imprensa/noticias-sp/mpf-inicia-projetosocioambiental-para-preservacao-da-ilha-das-couves-em-ubatuba-sp $>$. Acesso em 16 de outubro de 2019.

BRASIL. Lei $n^{0}$ 9.636, de 15 de maio de 1998. Dispõe sobre a regularização, administração, aforamento e alienação de bens imóveis de domínio da União. Brasília, 1998.

BURGOS, A.; MERTENS, F. Os desafios do turismo no contexto da sustentabilidade: as contribuições do turismo de base comunitária. PASOS Revista de Turismo y Patrimonio Cultural, v. 13, n. 1, p. 57-71, 2015.

BUTLER, R.W. The concept of a tourist area cycle of evolution: Implications for management of resources. Canadian Geographer 14 (1), 5-12, 1980.

CÂNDIDO, A. Parceiros do Rio Bonito: estudos sobre o caipira paulista e a transformação dos seus meios de vida. São Paulo: Ed. Livraria Duas Cidades, 1987. 
CAMACHO, R. S. A produção do espaço e do território: as relações de trabalho subordinadas ao modo de produção capitalista. Entre-lugar, n. 1, p. 73-98, 2010.

CALVENTE, M. C. M. H. Ilhabela: turismo e território. Revista Geografia (Londrina), v.8, n.1, p. 29-36, 1999.

CALVENTE, M. C. M. H. Questões sobre a desterritorialização de comunidades tradicionais e o turismo: o "novo senhor do curral". GeoTextos, v. 12, n. 2, 2016.

CAPElARI, M. G. M.; DE ARAÚJO, S. M. V. G.; CALMON, P. C. D. P. Vincent e Elinor Ostrom: duas confluentes trajetórias para a governança de recursos de propriedade comum. Ambiente \& Sociedade, v. 20, n. 1, p. 203-222, 2017.

CASSETI, V. Ambiente e apropriação do relevo. São Paulo: Contexto, 1991.

CHAUÍ, M. Natureza, cultura, patrimônio ambiental. In: Meio Ambiente: Patrimônio Cultural da USP. São Paulo: EDUSP, 2003.

CIOFFI, G.; RAIMUNDO, S. Áreas naturais protegidas: uma reflexão sobre a patrimonialização da natureza pela sociedade ocidental. Caderno Virtual de Turismo, v. 20, n. $2,2020$.

CONDEPHAAT - Conselho de Defesa do Patrimônio Histórico, Arqueológico, Artístico e Turístico do Estado de São Paulo. Resolução Condephaat $n^{\circ}$ 40/85, de 06 de junho de 1985.

COLISTETE, R. P. Regiões e especialização na agricultura cafeeira: São Paulo no início do século XX. Revista Brasileira de Economia, v. 69, n. 3, p. 331-354, 2015.

COPELLI, L. Estradas vicinais em municípios litorâneos. Estudo de caso: município de Ubatuba - SP. Trabalho de graduação - UNESP. Guaratinguetá, 2015.

CORIOLANO, L. N. M. T. O turismo comunitário no nordeste brasileiro. In: BARTHOLO, R.; SANSOLO, D. G.; BURSZTYN, I. Turismo de base comunitária. Rio de Janeiro: Letra e imagem, 2009.

COTA, L. G. S. Não só “para inglês ver”: justiça, escravidão e abolicionismo em Minas Gerais. História Social, n. 21, p. 65-92, 2011. 
COZZOLINO, L. F. Gestão de áreas protegidas: análise dos marcos legais à luz dos princípios de governança democrática. Sociedade e Território, v. 27, n. 1, p. 138-156, 2015.

CUNHA, M. C. “Cultura" e cultura: conhecimentos tradicionais e direitos intelectuais. Cultura com aspas e outros ensaios. São Paulo: Cosac Naify, 2009.

DARDOT, P.; LAVAL, C. La nouvelle raison du monde: essai sur la société néolibérale. La découverte, 2020.

DARDOT, P.; LAVAL, C. Comum: ensaio sobre a revolução do século XXI. São Paulo: Boitempo, 2017.

DELEUZE, G.; GUATTARI, F. Mil platôs: capitalismo e esquizofrenia (Vol. III). Rio de Janeiro: Ed, v. 34, 1996.

DIEGUES, A. C. S. Pesca e marginalização no litoral paulista. Dissertação de mestrado. Ciências Sociais - USP. São Paulo, 1973.

DIEGUES, A. C. S. Pescadores, camponeses e trabalhadores do mar. São Paulo: Ática, 1983.

DIEGUES, A. C. O mito moderno na natureza intocada. São Paulo: Editora Hucitec, 2008.

DINICA, V. Tourism concessions in National Parks: neo-liberal governance experiments for a Conservation Economy in New Zealand. Journal of Sustainable Tourism, v. 25, n. 12, p. 1811-1829, 2017.

DUMORA, C. Viver e sobreviver numa Área de Proteção Ambiental: o caso da pequena agricultura familiar em uma das comunidades rurais da APA de Guaraqueçaba. Desenvolvimento e meio ambiente, v. 14, 2006.

EAGLES, P. F. J. Governance of recreation and tourism partnerships in parks and protected areas. Journal of sustainable tourism, v. 17, n. 2, p. 231-248, 2009. 
ESTEVA, G. Development. In: SACHS, W. The Development Dictionary: a guide to knowledge as power. 2. ed. London: Zed Books, 1992, p. 1-23.

ESTIMA, D. C.; VENTURA, M. A. M.; RABINOVICI, A.; MARTINS, F. M. C. P. F. Concession in tourism services and partnerships in the Marine National Park of Fernando de Noronha, Brazil. Revista de Gestão Costeira Integrada, v. 14, n. 2, 2014.

FARIA, I. F. Ecoturismo, cultura e participação: gestão do território indígena no alto Rio Negro. In: BARTHOLO, R.; SANSOLO, D. G.; BURSZTYN, I. Turismo de base comunitária. Rio de Janeiro: Letra e imagem, 2009.

FONTANELLI, M. M. Rio-santos: a promessa da modernização e do turismo, conflitos de terras e resistência caiçara. Tempos Históricos, v. 22, n. 2, 2018.

FREY, K. A dimensão político-democrática nas teorias de desenvolvimento sustentável e suas implicações para a gestão local. Ambiente \& Sociedade, 2001.

FREY, K. Governança urbana e participação pública. RAC-eletrônica, v. 1, n. 1, p. 136$150,2007$.

GEERTZ, C. Uma Descrição Densa: Por Uma Teoria Interpretativa da cultura. In: GEERTZ, C. A Interpretação das culturas. Rio de Janeiro: Zahar, p. 3-21, 2008.

GODOY, A. S. Introdução à pesquisa qualitativa e suas possibilidades. Revista de administração de empresas, v. 35, n. 2, p. 57-63, 1995.

GRAHAM, J.; AMOS, B.; PLUMPTRE, T. W. Governance principles for protected areas in the 21st century. Ottawa: Institute on Governance, 2003.

GRIMM, I.; SAMPAIO, C. A. C. Turismo de base comunitária: convivencialidade e conservação ambiental. Revista Brasileira de Ciências Ambientais (Online), n. 19, p. 57-68, 2011.

HABERMAS, J. Técnica e ciência como ideologia. Lisboa: Edições 70, 1968.

HAESBAERT, R. Da desterritorialização à multiterritorialidade. Boletim Gaúcho de Geografia, v. 29, p. 11-24, 2003. 
HAESBAERT, R. Desterritorialização, multiterritorialidade e regionalização. In: FIGUEIREDO, A.H. Para pensar uma politica nacional de ordenamento territorial. Brasília: Ministério da Integração Nacional, 2005.

HAESBAERT, R. Território e multiterritorialidade: um debate. GEOgraphia, v. 9. n. 17, 2007.

HAESBAERT, R.; BRUCE, G. A desterritorialização na obra de Deleuze e Guattari. GEOgraphia, v. 4, n. 7, p. 7-22, 2002.

HAESBAERT, R.; LIMONAD, E. O território em tempos de globalização. GeoUERJ, n.5, p.7, 1999.

HANAI, F. Y. Desenvolvimento sustentável e sustentabilidade do turismo: conceitos, reflexões e perspectivas. Revista Brasileira de Gestão e Desenvolvimento Regional, 8(1), 2012.

HILAL, A. H.; ALABRI, S. S. Using nvivo for data analysis in qualitative research. International Interdisciplinary Journal of Education, v. 2, n. 2, 2013.

HOLANDA, L. R. “ABRINDO VELAS, PESCANDO CULTURAS”: Memória social, patrimônio cultural e defesa do território tradicional da comunidade de Caetanos de Cima no assentamento Sabiaguaba em Amontada, CE. Revista NUPEART, v. 15, n. 15, p. 77 $92,2016$.

HULME, D.; MURPHREE, M. Communities, wildlife and the 'new conservation' in Africa. Journal of International Development, v. 11, n. 2, 1999.

ICMBIO - Instituto Chico Mendes de Conservação da Biodiversidade. Roteiro Metodológico para Manejo de Impactos da Visitação com Enfoque na Experiência do Visitante e na Proteção dos Recursos Naturais e Culturais. 2011.

IRVING, M. A. Reinventando a refl exão sobre turismo de base comunitária: inovar é possível? In: BARTHOLO, R.; SANSOLO, D. G.; BURSZTYN, I. Turismo de base comunitária. Rio de Janeiro: Letra e imagem, 2009. 
ITANI, M. R. Zoneamento Ecológico-Econômico e territorialidades: estudo de caso no Litoral Norte Paulista. Tese de doutorado. FAUUSP. São Paulo, 2018.

JACOBI, P. R.; SINISGALLI, P. A. A. Governança ambiental e economia verde. Ciência \& Saúde Coletiva, v. 17, p. 1469-1478, 2012.

JORDAN, A.; LENSCHOW, A. Environmental policy integration: a state of the art review. Environmental Policy and Governance, 20(3), 147-158, 2010.

KINGDON, John. W. Agendas, Alternatives, and Public Policies. Em SARAVIA, E.; FERRAREZI, E. Políticas públicas, coletânea. Brasília: ENAP, 2006.

KISSLER, L.; HEIDEMANN, F. G. Governança pública: novo modelo regulatório para as relações entre Estado, mercado e sociedade? Revista de Administração Pública, v. 40, n. 3, p. 479-499, 2006.

LÉVI-STRAUSS, C. O pensamento selvagem. Campinas: Papirus, 2008.

LEUZINGER, M. D. Natureza e cultura: direito ao meio ambiente equilibrado e direitos culturais diante da criação de unidades de conservação de proteção integral e domínio público habitadas por populações tradicionais. Tese de doutorado. Desenvolvimento sustentável - UNB. Brasília, 2007.

LEWIS, C. Managing conflicts in protected areas. Cambridge: IUCN, 1996.

LITTLE, P. Territórios sociais e povos tradicionais no Brasil: por uma antropologia da territorialidade. Anuário Antropológico, v. 28, n. 1, p. 251-290, 2003.

LUCHIARI, M. T. D. P. Caiçaras, Migrantes e Turistas: a trajetória da apropriação da natureza no litoral norte paulista. Resgate: Revista Interdisciplinar De Cultura, v. 5, n.1, 1996.

LÜCHMANN, L. H. H. Modelos contemporâneos de democracia e o papel das associações. Revista de Sociologia e Política, v. 20, n. 43, p. 59-80, 2012. 
MACHADO, V. M. Sistemas de turismo e ordenamento do território no regime jurídico das áreas regionais de turismo e pólos de desenvolvimento turístico. Revista Dos Algarves, v. 19, p. 37-59, 2010.

MARANDOLA JR. E.; MARQUES, C.; PAULA, L.; CASSANELI, L. Crescimento urbano e áreas de risco no litoral norte de São Paulo. R. bras. Est. Pop., 30(1), 35-56. 2013.

MARCONDES, D. Os conflitos decorretnes do veraneio e do turismo sobre o território tradicional caiçara na Praia de Castelhanos a partir da década de 1950. Dissertação de mestrado. Turismo - EACH/USP. São Paulo, 2018.

MARCONDES, D.; RAIMUNDO, S. Povos tradicionais e turismo: o taus como instrumento Para gestão de conflitos? Ambiente \& Sociedade, v. 22, 2019.

MARTELETO, R. M.; SILVA, A. B. O. Redes e capital social: o enfoque da informação para o desenvolvimento local. Ciência da informação, v. 33, n. 3, p. 41-49, 2004.

MARTINS, J. B. Observação participante: uma abordagem metodológica para a psicologia escolar. Semina: Ciências, Sociedade e Humanidade, v. 17, n. 3, 1996.

MARTINS, J. T.; SANSOLO, D. G. A defesa do território das comunidades tradicionais do Litoral Norte Paulista e Sul Fluminense: uma análise do turismo de base comunitária e das iniciativas agroecológicas do Fórum de Comunidades Tradicionais de Angra/Paraty/Ubatuba. XII ENANPEGE. São Paulo, 2019.

MASCARO, A.L. Estado e forma política. São Paulo: Boitempo Editorial, 2013.

MCKEAN, M. A.; OSTROM, E. Regime de propriedade comum em florestas: somente uma relíquia do passado? Em DIEGUES, A. C. S; ANDRÉ DE CASTRO, C. M. Espaços e recursos naturais de uso comum. São Paulo: Hucitec Editora, 2001.

MERTENS, F.; TÁVORA, R.; FONSECA, I. F. D.; GRANDO, R.; CASTRO, M.; DEMEDA, K. Redes sociais, capital social e governança ambiental no Território Portal da Amazônia. Acta Amazônica, v. 41, n. 4, p. 481-492, 2011.

MONDARDO, M. Territórios de povos e comunidades tradicionais: Estado de exceção, governo bio/necropolítico e retomadas de Tekoha. Horizontes, v. 37, 2019. 
MONTEIRO, Z. M. H.; VIEIRA, T. O papel da liderança informal na comunicação interna. Revista Brasileira de Marketing, v. 7, n. 2, p. 195-201, 2008.

MORAES, N. BRUMATti, L. M., LiMA, A. R., \& CAMPOS, A. C. Análise da convergência conceitual dos termos "território" e "comunidade tradicional" no Brasil. Revista Observatório, v. 3, n. 4, p. 518-539, 2017.

MOREIRA, E. M. APA Tarumã Ponta Negra e o papel sociopolítico do Conselho Gestor na construção do seu futuro. Dissertação de mestrado. Ciências do ambiente - UFAM. Manaus, 2019.

MORIN, E. Introdução do pensamento complexo. Tradução: Eliane Lisboa. Porto Alegre: Sulina, 2006.

MORIN, E. O método III: O conhecimento do conhecimento. Portugal: Edições EuropaAmérica, 1996.

NASCIMENTO, P. S. S. Gestão em áreas protegidas: proposição metodológica para análise de impactos socioambientais nas comunidades tradicionais da APA Chapada do Araripe. Tese de doutorado. Geiografia - UNESP. São Paulo, 2013.

NEVES, J. L. Pesquisa qualitativa: características, usos e possibilidades. Caderno de pesquisas em administração, v. 1, n. 3, p. 1-5, 1996.

OJEDA, D. Green pretexts: Ecotourism, neoliberal conservation and land grabbing in Tayrona National Natural Park, Colombia. Journal of Peasant Studies, v. 39, n. 2, 2012.

OKAZAKI, E. A Community-Based Tourism Model: Its Conception and Use. Journal of Sustainable Tourism, 16(5), 511-529, 2008.

PELEGRINI, S. C. A. A gestão do patrimônio imaterial brasileiro na contemporaneidade. Revista Brasileira de História, v. 26, n. 51, p. 115-140, 2006.

PEREIRA, B. E.; DIEGUES, A. C. Conhecimento de populações tradicionais como possibilidade de conservação da natureza: uma reflexão sobre a perspectiva da etnoconservação. Desenvolvimento e Meio ambiente, n. 22, p. 37-50, 2010. 
PÉREZ, X. P. Patrimonialização e transformação das identidades culturais. Portugal chão, p. 231-247, 2003.

PESSOA, T. C. Sobre o que se quis calar: o tráfico de africanos no litoral norte de São Paulo em tempos de pirataria. História (São Paulo), v. 39, 2020.

PINTO, P. M. Políticas de turismo e sustentabilidade em comunidades tradicionais: perspectivas conceituais. Boletim do Museu Paraense Emílio Goeldi. Ciências Humanas, v. 2, n. 1, p. 11-22, 2007.

PLUMMER, R.; FENNELL, D. A. Managing protected areas for sustainable tourism: prospects for adaptive co-management. Journal of Sustainable Tourism, 17(2), 149$168,2009$.

QUEIROZ, J. F. Projetos ambientalistas em Ubatuba: circulação de capitais sociais entre Estado, ONGs e populações tradicionais. Dissertação de mestrado. Ciências sociais UNIFESP. São Paulo, 2015.

QUIJANO, A. Cuestiones y horizontes: de la dependencia histórico-estructural a la colonialidad/descolonialidad del poder: antología esencial. Buenos Aires: Clacso, 2014.

RAFFESTIN, C. Por uma geografia do poder. São Paulo: Ática, 1993.

RAIMUNDO, S. As ondas do litoral norte (SP) : difusão espacial das praticas caiçaras e do veraneio no Nucleo Picinguaba do Parque Estadual da Serra do Mar (1966-2001). Tese de Doutorado. Instituto de Geociências, Universidade de Campinas. 2007.

RAIMUNDO, S. Conservação da natureza e turismo no Núcleo Picinguaba do Parque Estadual da Serra do Mar (SP). Revista Brasileira de Ecoturismo, v. 1, n. 1, 2008.

RAIMUNDO, S.; PACHECO, R.; COSTA, B. M. Construindo um programa de uso público para unidades de conservação em áreas metropolitanas: a experiência dos Parques Naturais Municipais de Itapecerica da Serra e Embu das Artes - RMSP (SP). Olam: Ciência \& Tecnologia (Rio Claro. Online), v. 11, p. 196-221, 2011.

RIBEIRO, L. P. A importância da Participação Social na Elaboração de Planos de Manejo de Unidades de Conservação Marinhas: O estudo de caso da APA Marinha do Litoral 
Norte de São Paulo. Dissertação de mestrado. Biodiversidade em Unidades de Conservação - Instituto de Pesquisas Jardim Botânico do Rio de Janeiro. Rio de Janiero, 2017.

RAMIRES, M.; BARRELLA, W. Ecologia da pesca artesanal em populações caiçaras da Estação Ecológica de Juréia-Itatins, São Paulo, Brasil. Interciencia, v. 28, n. 4, p. 208$213,2003$.

RODRIGUES, C. G. O. O uso do público nos parques nacionais: a relação entre as esferas pública e privada na apropriação da biodiversidade. Tese de doutorado. Centro de Desenvolvimento Sustentável, Universidade de Brasília. 2009.

RODRIGUES, C. G. O.; ABRUCIO, F. L. Parcerias e concessões para o desenvolvimento do turismo nos parques brasileiros: possibilidades e limitações de um novo modelo de governança. Revista Brasileira de Pesquisa em Turismo, v. 13, n. 3, p. 105-120, 2019.

SACK, R. Human Territoriality: its theory and history. Cambridge : Cambridge University Press, 1986.

SANTOS, B. S. Um discurso sobre as ciências. São Paulo: Cortez, 2008.

SAQUET, M. A.; SPOSITO, E. S. Territórios e territorialidades: teorias, processos e conflitos. São Paulo: Editora expressão popular, 2009.

SANSOLO, D. Centralismo e participação na proteção da natureza e desenvolvimento do turismo no Brasil. In: BARTHOLO, R.; SANSOLO, D. G.; BURSZTYN, I. Turismo de base comunitária. Rio de Janeiro: Letra e imagem, 2009.

SANSOLO, D. G.; BURSZTYN, I. Turismo de base comunitária: pontencialidade no espaço rural brasileiro. In: BARTHOLO, R.; SANSOLO, D. G.; BURSZTYN, I. Turismo de base comunitária. Rio de Janeiro: Letra e imagem, 2009.

SANTANA, C. G. As percepções ambientais de pescadores e marisqueiras acerca da divisão sexual de trabalho na pesca em Pirambu/SE. Revista Ambivalências, v. 2, n. 3, p. 86-105, 2014. 
SANTOS, V. C. Populações tradicionais litorâneas: o modo de vida caiçara. Revista de Geografia-PPGEO-UFJF, v. 2, n. 2, 2012.

SÃO PAULO (Estado). Secretaria do Meio Ambiente. Plano de Manejo da Área de Proteção Ambiental Marinha do Litoral Norte. São Paulo, 2049.

SÃO PAULO (Estado). Secretaria do Meio Ambiente. Fundação Florestal. Produto 3 Diagnóstico Participativo Apa Marinha Do Litoral Norte E Arie De São Sebastião. São Paulo, 2012.

SÃO PAULO (Estado). Secretaria do Meio Ambiente. Instituto Florestal. Plano de Manejo do Parque Estadual da Serra do Mar. São Paulo, 2008.

SÃO PAULO (Estado). Decreto $\mathrm{n}^{\circ} 53.525$, de 8 de outubro de 2008. Cria a Área de Proteção Ambiental Marinha do Litoral Norte e a Área de Relevante Interesse Ecológico de São Sebastião. Assembleia Legislativa do Estado de São Paulo, 2008.

SÃO PAULO (Estado). Lei n ${ }^{\circ} 10.019$, de 03 de julho de 1998. Dispões sobre o Plano Estadual de Gerenciamento Costeiro. Assembleia Legislativa do Estado de São Paulo, 1998.

SCARANO, F. R.; CEOTTO, P. Brazilian Atlantic forest: impact, vulnerability, and adaptation to climate change. Biodiversity and Conservation, v. 24, n. 9, p. 2319-2331, 2015.

SCATAMACCHIA, M. C. M.; MOSCOSO, F. Análise do padrão de estabelecimentos Tupi-Guarani: fontes etno-históricas e arqueológicas. Revista de antropologia, p. 37-53, 1987.

SEABRA, L. S. Monitoramento participativo do turismo desejável: contribuição aos estudos de capacidade de suporte turístico. 2005. Disponível em: <docplayer. com. br/7460679-Monitoramento-participativo-do-turismo-desejavelcontribuicao-aosestudos-de-capacidade-de-suporte-turistico. Html>. Acesso em: 20 de janeiro de 2021.

SELIN, S.; CHAVEZ, D. Developing an evolutionary tourism partnership model. Annals of tourism research, v. 22, n. 4, p. 844-856, 1995. 
SILVA, N. L. O protagonismo na comunidade Santa Luzia do Baixio: o olhar sobre suas lideranças. Dissertação de mestrado. Sociedade e Cultura na Amzônia, UFAM. Manaus, 2008.

SILVEIRA, S. A.; SAVAZONI, R. T. O conceito do comum: apontamentos introdutórios. Liinc em Revista, v. 14, n. 1, 2018.

SIMÕES, E. O dilema das decisões sobre populações humanas em Parques = jogo compartilhado entre técnicos e residentes no Núcleo Picinguaba. Tese de doutorado. Universidade Estadual de Campinas, Instituto de Filosofia e Ciências Humanas, 2010.

SIMÕES, J.; MACEDO, M.; BABO, P. Elinor Ostrom:“Governar os comuns”. Economia e política do ambiente, 2011.

SOARES, L. Q.; FERREIRA, M. C. Pesquisa participante como opção metodológica para a investigação de práticas de assédio moral no trabalho. Revista Psicologia: Organizações e Trabalho, v. 6, n. 2, p. 85-109, 2006.

SOJA, E. The Political Organization of Space, Washington: Association of American Geographers. Resource Paper, n. 8, 1971.

SOLIKU, O.; SCHRAML, U. Making sense of protected area conflicts and management approaches: A review of causes, contexts and conflict management strategies. Biological Conservation, v. 222, 2018.

SOUZA, F. A. Z. Gestão de unidades de conservação da natureza no Estado de São Paulo : a influência do arranjo institucional nas ações governamentais . Tese (doutorado) Universidade Estadual de Campinas, Instituto de Filosofia e Ciências Humanas, Campinas, SP. 2020.

SOUZA-LIMA, J. E. Economia ambiental, ecológica e marxista versus recursos naturais. In: OLIVEIRA, G. B.; DE SOUZA-LIMA, J. E. O desenvolvimento sustentável em foco: uma contribuição multidisciplinar. São Paulo: ANNABLUME, 2006, p. 45-57. 
SOUZA, P. C.; MARTOS, H. L. Estudo do uso público e análise ambiental das trilhas em uma unidade de conservação de uso sustentável: Floresta Nacional de Ipanema, Iperó - SP. Revista Árvore, v. 32, n. 1, 2008.

SOUZA, K. F. D. O. Fossas negras: um problema para o meio ambiente e para a saúde pública. Trabalho de Conclusão de Curso. Gestão Ambiental - FAEMA. Ariquemes, 2015.

SPU - SECRETARIA DE PATRIMÔNIO DA UNIÃO. Portaria n 89, de 15 de abril de 2010. Brasília, 2010.

SUBIRATS, J. Definición del problema. Relevancia pública y formación de la agenda de actuación de los poderes públicos. Em SARAVIA, E.; FERRAREZI, E. (Orgs.). Políticas públicas, coletânea. Brasília: ENAP, 2006.

TABARElli, M.; PINTO, L. P., SIlVA, J. M. C.; HIROTA, M. M.; BEDÊ, L. C. Desafios e oportunidades para a conservação da biodiversidade na Mata Atlântica brasileira. Megadiversidade, v. 1, n. 1, 2005.

TAKAHASHI, L. Y., \& CEGANA, A. C. Como monitorar o impacto dos visitantes utilizando o sistema LAC - Limite Aceitável de Câmbio. Revista Turismo Em Análise, 16(2), 206-222, 2005.

THIOLLENT, M.; DE OLIVEIRA SILVA, G. Metodologia de pesquisa-ação na área de gestão de problemas ambientais. Revista eletrônica de comunicação, Informação e Inovação em Saúde, v. 1, n. 1, 2007.

TIRIBA, L. V.; FISCHER, M. C. B. Espaços/tempos milenares dos povos e comunidades tradicionais: notas de pesquisa sobre economia, cultura e produção de saberes. Revista de educação pública, vol. 24, n. 56, p. 405-428, 2015.

TOSUN, C. Expected nature of community participation in tourism development. Tourism Management, 27(3), 493-504, 2006.

UBATUBA. Ilha das Couves: Prefeitura e comunidade da Picinguaba discutem gestão. $\begin{array}{llll}\text { Prefeitura } & \text { Municipal, } & \text { 2019. } & \text { Disponível }\end{array}$ https://www.ubatuba.sp.gov.br/smma/comunidade-da-picinguaba-reune-se-com- 
representantes-da-prefeitura-de-ubatuba-para-discutir-gestao-da-ilha-das-couves/>. Acesso em: 15 de outubro de 2019.

UBATUBA. MPF e comunidade reúnem-se para discutir turismo na Ilha das Couves. Prefeitura Municipal, 2018. Disponível em: $<$ https://www.ubatuba.sp.gov.br/smma/mpfe-comunidade-reunem-se-para-discutir-turismo-na-ilha-das-couves/>. Acesso em: 15 de outubro de 2019.

UBATUBA. Reunião do Conselho Municipal de Turismo debate questões relevantes para a temporada 2017/2018. Prefeitura Municipal, 2017. Disponível em: $<$ https://www.ubatuba.sp.gov.br/secretarias/reuniao-do-conselho-municipal-de-turismodebate-questoes-relevantes-para-a-temporada-20172018/>. Acesso em: 15 de outubro de 2019.

UBATUBA. Ubatuba intensifica ações de fiscalização dos atrativos turísticos naturais. Prefeitura $2016 . \quad$ Dunicipal, em: $<$ https://www.ubatuba.sp.gov.br/smt/ubatuba-intensifica-acoes-de-fiscalizacao-dosatrativos-turisticos-naturais/>. Acesso em: 15 de outubro de 2019.

UBATUBA. Prefeitura Municiapl da Estância Balneária de Ubatuba. Plano Municipal de Gestão Integrada de Resísuos Sólidos. 2014.

UCHÔA, D. P. A Ilha do Mar Virado: estudo de um sítio arqueológico no litoral Norte do Estado de São Paulo. CLIO-Série Arqueológica, v. 24, n. 1, 2009.

VALLEJO, L. R. Unidade de conservação: uma discussão teórica à luz dos conceitos de território e políticas públicas. Geographia, v. 4, n. 8, p. 57-78, 2002.

VALLEJO, L. R. Uso público em áreas protegidas: atores, impactos, diretrizes de planejamento e gestão. Anais do Uso Público em Unidades de Conservação, v. 1, n. 1, p. 13-26, 2013.

VENTURI, L. A. B. Recurso natural: a construção de um conceito. GEOUSP: Espaço E Tempo, n. 20, p. 9-17, 2006. 
VIANNA, L.; BRITO, M. C. Vila de Picinguaba: O caso de uma comunidade caiçara no interior de uma área protegida. Anais - $2^{\circ}$ Congresso Nacional sobre Essências Nativas 1992.

VIANNA, L. P. De invisíveis a protagonistas: populações tradicionais e unidades de conservação. São Paulo: Annablume Editora, 2008.

VIEIRA, L. S. O turismo náutico e seus efeitos sobre a biodiversidade da assembleia de peixes recifais no costão rochoso da praia do forno em Arraial do Cabo-RJ. Trabalho de conclusão de curso. Ciências Ambientais - UFRJ. Rio de Janeiro, 2019.

VIEITAS, C. F.; ALMEIDA, A. F. Análise ambiental das ilhas da região de Ubatuba (SP), e proposta de manejo para a Ilha do Mar Virado. Tese (mestrado). Universidade de São Paulo, Instituto de Biociências, 1995.

VITORINO, M. R. Levantamento dos grupos de pesquisa em áreas naturais protegidas e uso público no Brasil. Cerne, v. 22, n. 3, 2016.

YIN, R. K. Estudo de Caso: Planejamento e métodos. Porto Alegre: Bookman, 2005.

ZACHRISSON, A. Commons protected for or from the people?: Co-management in the Swedish mountain region?. Tese de Doutorado. Statsvetenskapliga institutionen, Umeå universitet, 2009.

ZANIRATO, S. H.; RIBEIRO, W. C. Patrimônio cultural: a percepção da natureza como um bem não renovável. Revista Brasileira de História, v. 26, n. 51, p. 251-262, 2006.

ZHOURI, A. Justiça ambiental, diversidade cultural e accountability: desafios para a governança ambiental. Revista brasileira de ciências sociais, v. 23, n. 68, p. 97-107, 2008 .

YAMAOKA, J. G.; CARDOSO, T. M., DENARDIN, V. F., \& ALVES, A. R. A comunidade caiçara da Enseada da Baleia e a sua luta pelo território-Cananéia (SP). Guaju, v. 5, n. 1, p. 138-165, 2019.

YIN, R. K. Estudo de Caso: Planejamento e métodos. Bookman editora, 2015. 
WU, J.; HU, Y.; LIU, T.; HE, Q. Value capture in protected areas from the perspective of common-pool resource governance: A case study of Jiuzhai Valley National Park, China. Land Use Policy, 79, 452-462, 2008. 


\section{ANEXOS}

\section{ANEXO I. ROTEIRO DA ENTREVISTA}

\section{PERFIL}

1. Nome

2. Qual segmento atua?

a) Poder público

b) Sociedade civil

c) Iniciativa Privada

d) Outros

3. Nome da instituição/organização/empresa.

4. Sobre a associação:

4.1. Número de associados

4.2. Perfil dos associados

\section{ATUAÇÃO (todos os atores)}

1. Qual é o seu envolvimento em Picinguaba e na Ilha das Couves?

2. Há quanto tempo atua na área?

3. A atuação é formalizada através de algum instrumento legal/administrativo?

4. O local é o único ou o principal produto/meio de subsistência?

5. Participa do conselho consultivo do PESM ou da APAMLN?

6. Avalie e comente a participação dos seguintes atores no planejamento e ordenamento do turismo na área, de acordo com as métricas "não participa", "participa escassamente" ou "participa ativamente".

a) Fundação Florestal (PESM/APAMLN) 
b) Prefeitura Municipal de Ubatuba

c) Empresas de turismo

d) Associações locais

e) $\mathrm{FCT}$

f) Linha dÁgua

g) OTSS

h) Marinha

i) $\mathrm{MPF}$

7. Na sua opinião, quais são os principais desafios para o desenvolvimento do turismo no local? Comente.

a) Divergência de objetivos entre atores atuantes na área

b) Falta de espaços que possibilitem o diálogo entre todos os atores

c) Omissão ou interferência negativa do poder público

d) Pressão por parte de empresas turísticas que possuem interesse em explorar o local

e) Pressão por parte das políticas de proteção ambiental

f) Pressão por parte de associações locais

g) Dificuldade de formalização dos serviços prestados ou de parcerias

h) Outros

PERCEPÇÃO SOCIOAMBIENTAL (poder público/ iniciativa privada)

1. Qual é a sua percepção sobre a participação de comunidades locais na atividade turística em territórios que estão inseridos? 
2. Sobre os impactos do turismo desordenado na Ilha das Couves, qual/ais ao seu ver é/são o/os mais grave/es?

3. Há algum tipo de estratégia por parte da associação para mitigar estes impactos?

4. Sobre os efeitos das medidas adotadas pelo "Plano de ordenamento e gestão comunitária para o uso público sustentável da Ilha das Couves do território tradicional caiçara de Picinguaba", quais foram na sua opinião os mais benéficos e os mais prejudiciais?

\section{PERCEPÇÃO SOCIOAMBIENTAL (Comunidade/parceiros)}

1. Sobre os impactos do turismo desordenado na Ilha das Couves, qual/ais ao seu ver é/são o/os mais grave/es?

2. O que Picinguaba e a Ilha das Couves representam para a existência e resistência da Comunidade Tradicional Caiçara local?

3. Ao seu ver, em que momento a conservação ambiental e a preservação da cultura tradicional e a garantia de uso tornam-se complementares e não antagônicos?

4. O que simboliza a sobreposição de duas áreas ambientais protegidas sobre o território tradicional de Picinguaba?

5. A efetivação do "Plano de ordenamento e gestão comunitária para o uso público sustentável da Ilha das Couves do território tradicional caiçara de Picinguaba" representou importantes conquistas materiais e simbólicas. Como você enxerga essa afirmação?

6. Quais foram os principais impactos do TBC para as famílias caiçaras e para as áreas protegidas locais?

7. Ao seu ver, qual foi o maior desafio e avanço do processo de gestão comunitária do turismo dentro de uma área protegida?

SOBRE A COVID-19 E MEDIDAS SANITÁRIAS (apenas para a Comunidade) 
1. Na sua opinião, como o processo de gestão comunitária influenciou o modo como a Comunidade lidou com a pandemia do Covid-19?

2. Quais foram as ações coletivas realizadas no território?

3. Houve algum apoio ou pressão dos órgãos públicos nessas iniciativas?

4. Qual foi o maior desafio enfrentado por vocês nesse período?

5. Como se deu a retomada do turismo na área? 


\section{ANEXO II. TERMO DE CONSENTIMENTO LIVRE E ESCLARECIDO}

Prezado (a),

Esta pesquisa, intitulada "Conflitos no desenvolvimento do uso público em áreas protegidas: o Turismo de Base Comunitária e o Território Tradicional Caiçara de Picinguaba", tem como objetivo compreender como o Turismo de Base Comunitária pode ser um instrumento para mitigar conflitos socioambientais em unidades de conservação, de modo a contribuir para uma gestão do uso público mais democrática e participativa.. Visando atingir esse objetivo, será necessário a realização de entrevistas com pessoas que estão envolvidas diretamente neste tema, para que seja possível compreender as diferentes visões.

A realização deste estudo contribuirá para a democratização da gestão dessas áreas, apresentando uma estratégia coletiva e comunitária para o desenvolvimento do uso público, onde a conservação ambiental e a garantia dos direitos de comunidades tradicionais dialogam de maneira construtiva.

Sendo assim, entedemos que sua participação será importante para o prosseguimento da pesquisa e solicitamos sua colaboração nas entrevistas. Solicitamos também sua autorização para apresentar e publicar em revista científica os resultados deste estudo. Por ocasião da publicação dos resultados, seu nome será mantido em sigilo.

É importante evidenciar que, apesar de mínimo, esse projeto contém risco referente a possibilidade de má interpretação do conteúdo obtido durante as entrevistas. Portanto, para minizar esta possibilidade, nos comprometemos a fazer o registro detalhado do que for dito, a apresentar o resultado final para a Comunidade Tradicional Caiçara de Picinguaba e a reparar erros de interpretação, caso ocorram.

Esclarecemos que sua participação no estudo é voluntária e, portanto, o(a) senhor(a) não é obrigado(a) a fornecer as informações e/ou colaborar com as atividades solicitadas pelo Pesquisador(a). Caso decida não participar do estudo, ou resolver a qualquer momento desistir do mesmo, não sofrerá nenhum dano. Este documento será emitido em duas vias, sendo que uma delas será entregue ao entrevistado. 
A pesquisadora responsável, Giovana Cioffi Nascimento, estará a sua disposição para qualquer esclarecimento que considere necessário em qualquer etapa da pesquisa e pode ser contatada pelo e-mail giovanacioffi@gmail.com ou pelo telefone (13) 997570666.

Caso seja de interesse do entrevistado, é possível entrar em contato com Comitê de Ética em Pesquisa em Seres Humanos - CEP da Escola de Artes, Ciências e Humanidades (EACH) da Universidade de São Paulo (USP), responsável pela aprovação desta pesquisa, pelo telefone (11) 3091-1046, pelo e-mail cep-each@usp.br ou pelo endereço Rua Arlindo Béttio, 1000 - Ermelino Matarazzo, São Paulo - SP, 03828-000.

Diante do exposto, declaro que fui devidamente esclarecido(a) e dou o meu consentimento para participar da pesquisa e para publicação dos resultados. Estou ciente que receberei uma cópia desse documento.

Data:

Nome completo:

Assinatura: 
Plano de ordenamento e gestão comunitária para o uso público sustentável da Ilha das Couves do território tradicional caiçara da Picinguaba

05 de maio de 2020

Realização:

Associação de Moradores do Bairro da Picinguaba - AMBP Associação de Barqueiros e Pescadores da Comunidade Tradicional da Picinguaba - ABPP Associação de Barqueiros e Pescadores Tradicionais da Picinguaba - ABPTP

Fórum de Comunidades Tradicionais e Rede Nhandereko Observatório de Territórios Sustentáveis e Saudáveis da Bocaina-OTSS Travessia Assessoria Socioambiental

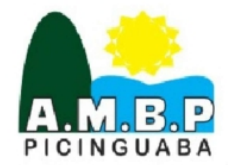

\section{FÓRUM DE REDE COMUNIDADES G
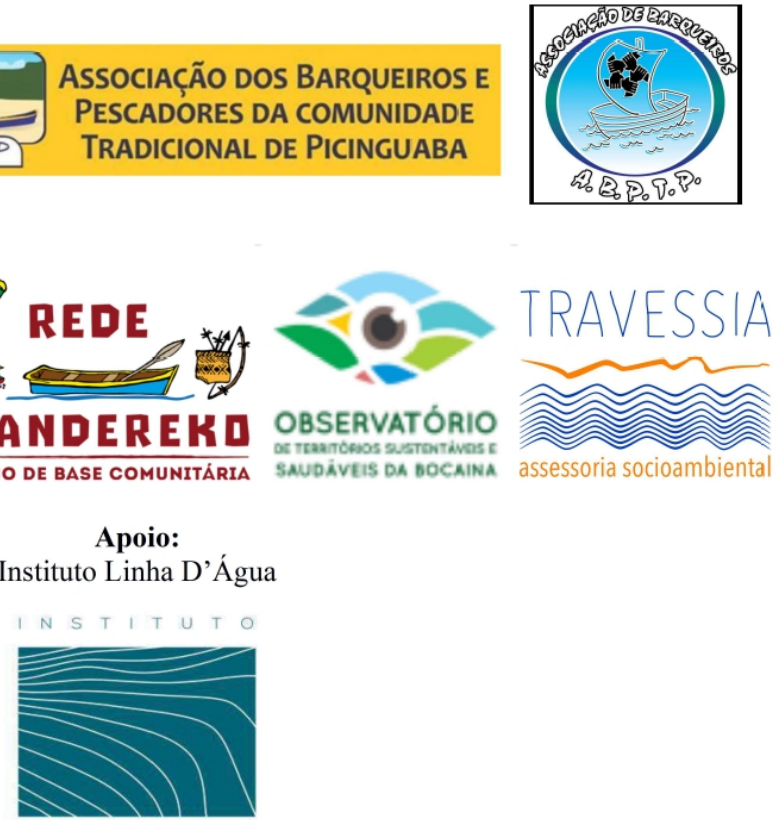
ANEXO IV. MAPA DO PROJETO DE ORDENAMENTO MARINHO DA ILHA DAS COUVES DO GT TBC PICINGUABA

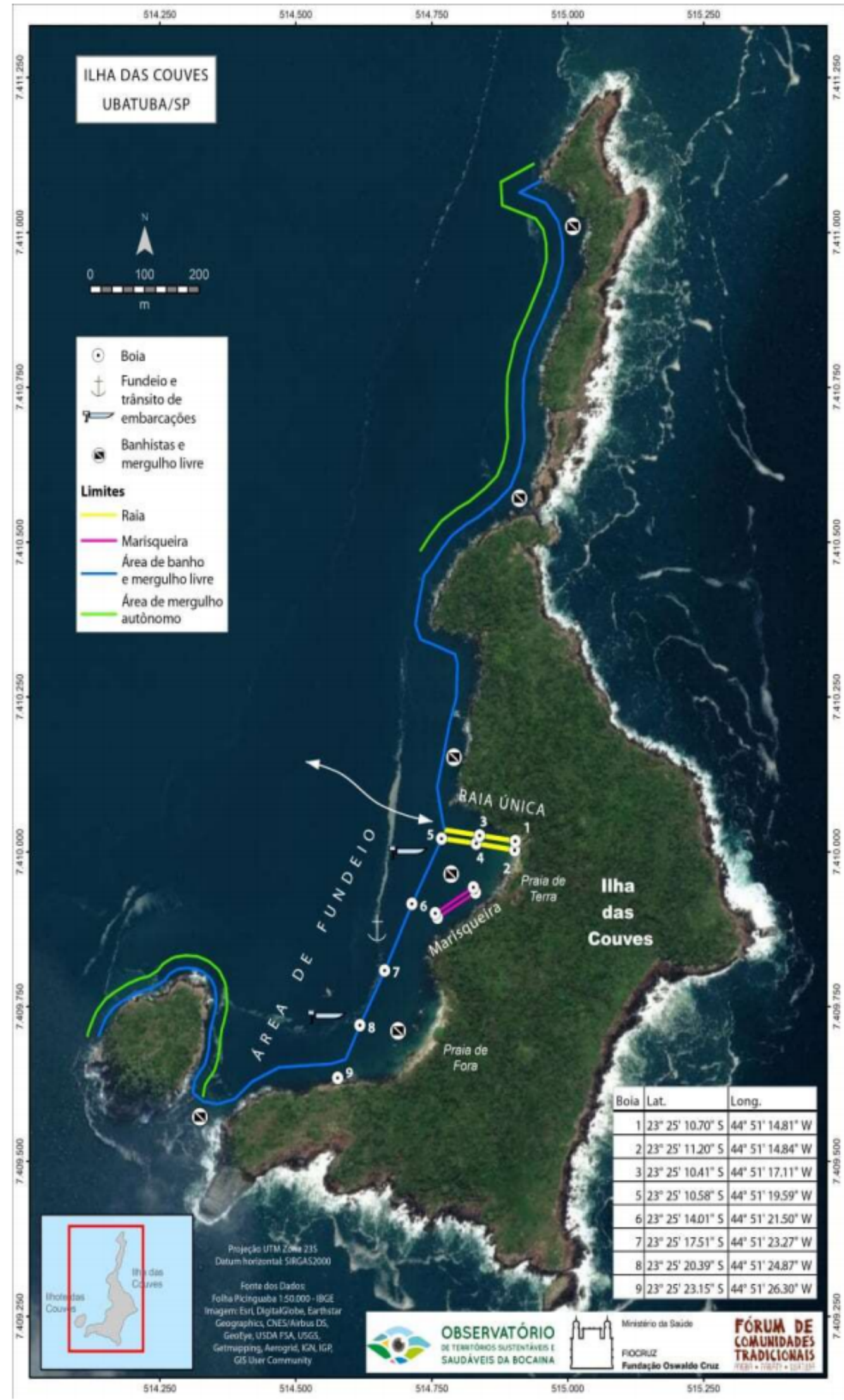

